\title{
Archaeological Evaluation of Sandy Mantle Prehistoric and Historic Sites at Camp Swift, Bastrop County, Texas: 2003
}

David L. Nickels

Melissa L. Lehman

Center for Archaeological Studies

Follow this and additional works at: https://scholarworks.sfasu.edu/ita

Part of the American Material Culture Commons, Archaeological Anthropology Commons, Environmental Studies Commons, Other American Studies Commons, Other Arts and Humanities Commons, Other History of Art, Architecture, and Archaeology Commons, and the United States History Commons

Tell us how this article helped you.

This Article is brought to you for free and open access by the Center for Regional Heritage Research at SFA ScholarWorks. It has been accepted for inclusion in Index of Texas Archaeology: Open Access Gray Literature from the Lone Star State by an authorized editor of SFA ScholarWorks. For more information, please contact cdsscholarworks@sfasu.edu. 


\section{Archaeological Evaluation of Sandy Mantle Prehistoric and Historic Sites at Camp Swift, Bastrop County, Texas: 2003}

\section{Creative Commons License}

\section{(c) (1) (8)}

This work is licensed under a Creative Commons Attribution-NonCommercial 4.0 International License 



\title{
Archaeological Evaluation of Sandy Mantle Prehistoric and Historic Sites at Camp Swift, Bastrop County, Texas: 2003
}

\author{
Principal Investigators \\ C. Britt Bousman \\ and David L. Nickels
}

Archaeological Studies

Report No. 5

Center for Archaeological Studies

Texas State University-San Marcos 
The following information is provided in accordance with the General Rules of Practice and Procedure, Title 13, Chapter 26, Texas Administrative Code:

1. Type of investigation: Phase I testing of prehistoric and historic archaeological sites

2. Project name: Archaeological Evaluation of Sandy Mantle Prehistoric and Historic Sites at Camp Swift, Bastrop County, Texas

3. County: Bastrop

4. Principal Investigators: C. Britt Bousman and David L. Nickels

5. Name and location of sponsoring agency: The Adjutant General's Department of Texas, Directorate of Facilities and Engineering, Environmental Branch, Austin, Texas

6. Published by the Center for Archaeological Studies, Texas State University-San Marcos, 601 University Drive, San Marcos, Texas 78666 (2003)

Texas State University- San Marcos is a member of the Texas State University System Copyright $@ 2004$ by Center for Archaeological Studies at Texas State University-San Marcos

All rights reserved.

No part of this book may be reproduced or utilized in any form or by any means, electronic or mechanical, including photocopying, recording or by any information storage and retrieval system without permission in writing.

For further information on this and other publications by the Centerfor Archaeological Studies, please contact:

\section{Center for Archaeological Studies}

Texas State University-San Marcos

601 University Drive

San Marcos, Texas 78666

www.txstate.edu/anthropology/cas/

Editors: Karen Elliott Fustes, Melissa L. Lehman, and Richard K. Meadows

Cover photography: French engineer and winemaker Antoine Aussilloux constructed this sandstone dam over Spring Branch (Scott Falls Creek) around 1886.

Printed in the United States of America 


\section{Management Summary}

\section{Management Objectives}

The Texas Army National Guard conducts military training on Camp Swift, an approximately 11,500acre tract in northern Bastrop County, Texas. As required by law, an environmental assessment of the area was conducted with pedestrian surveys beginning as early as 1979. The Adjutant General's Department of Texas (AGTX) was charged with oversight management of archaeological compliance for the Camp. The survey was undertaken to meet requirements under sections 106 and 110 of the National Historic Preservation Act (NHPA). Under sections 106 and 110 of the NHPA, the protection of cultural resources is related to their eligibility for inclusion in the National Register of Historic Places (NRHP), which is in turn dependent on their NRHP significance as defined in 36 CFR Part 60. The National Historic Preservation Act Amendments of 1992 clarified Section 110 and directed federal agencies to establish preservation programs corresponding to their activities and effects on historic properties. Under Section 110 , federal agencies may evaluate the significance of cultural resources not currently threatened to assist with the development of preservation planning.

The purpose of the surveys was to provide the Texas National Guard with recommendations as to the eligibility of the sites for nomination to the National Register of Historic Places (NRHP). In the case of prehistoric sites, significance is often based on Criterion D of the National Historic Preservation Act (NHPA) as defined by the National Park Service in 36 CFR 60. The significance of a site under Criterion $\mathrm{D}$, and therefore its eligibility for listing on the NHRP, is based on its having yielded information important in history or prehistory, or on its having the potential to yield such information in the future. The question of what information is important, a point not addressed in the NRHP, is a function of research questions or developed historic contexts.

\section{Contracting Parties}

The Center for Archaeological Studies (CAS) of Southwest Texas State University (now Texas State University-San Marcos) contracted with the sponsoring agency, the Texas Army National Guard. The investigations were conducted under interagency cooperative agreement number TX 01-ENV-29 401-24652. C. Britt Bousman and David L. Nickels served as co-principal investigators for the 2002-2003 project. David L. Nickels directed the daily field operations.

\section{Scope of Work}

The purpose of this project was to relocate, re-evaluate, and map archaeological sites on Camp Swift property that were being affected directly or indirectly by the proposed military training. In December 2002 and January 2003, CAS fulfilled a contractual agreement with AGTX to conduct an intensive cultural 
resources inventory on the remaining 19 sites recommended for re-evaluation. A total of 267 shovel tests were placed on 17 of those sites. An additional 44 shovel tests were placed around 41BP138, an historic winery operation. Finally, additional mapping and inventories were conducted at two sites: 1) 41BP148, a mining operation and residential area, and 2) 41BP146, an isolated historic burial. The completion of this project finalizes the listing of sites that required further testing, mapping, and reevaluation (see Mauldin 2001:181; Category 6 Sites).

\section{Summary of Results and Site Significance}

Twenty archaeological sites were revisited; of the 20 documented sites, 15 have prehistoric components only, 3 have both prehistoric and historic components, and 2 sites have only a historic component. Prehistoric site types included open campsites and lithic scatters. Diagnostic artifacts found on the prehistoric sites both during the surveys and during this testing project suggest they were occupied during the Late Archaic and Late Prehistoric periods. Historic sites date to the late-nineteenth and earlyto mid-twentieth centuries, and included a farmstead, a winery operation, vineyard fields, a mining and associated residential area, and an isolated grave.

\section{Prehistoric Sites}

Prehistoric research issues discussed in this report include the formation of the sandy mantle, site formation processes, and site integrity.

Sites were judged based on the following criteria:

High potential: High integrity sites. Sites upon which shovel test results have indicated a pattern of stratified deposits, have potentially buried, intact deposits and/or datable features, and otherwise have the potential to address research issues.

Moderate potential: Potentially high integrity sites. Sites upon which shovel testing results have not clearly demonstrated high integrity, but with further testing could yield buried, intact deposits and/or datable features, and otherwise have the potential to address research issues.

Minimal potential: Little or no integrity sites. Sites upon which shovel testing results have produced no evidence of intact deposits, and/or have otherwise been disturbed so that there is little or no potential for providing credible information.

As the current project involved only limited testing, recommendations required to be made by CAS according to the survey contract were as follows: 1) Eligible for the National Register of Historic Places,

2) Not eligible for the National Register of Historic Places, or 3) Requires further investigation beyond the scope of this testing project. 
There are seven prehistoric site components and/or distinct prehistoric component areas of sites we assess as having little or no integrity, likewise having minimal research potential, and thus recommended as not eligible for the National Register of Historic Places.

There are two prehistoric site components we assess as demonstrating moderate integrity, and potentially capable of having high research potential; thus we believe further investigation beyond the scope

of this inventory survey are required before recommendations can be made regarding their eligibility for nomination to the National Register of Historic Places.

There are nine prehistoric site components and/or distinct prehistoric component areas of sites we assess as demonstrating high integrity, and likewise having high research potential. However, we believe further investigations beyond the scope of this inventory survey are required before recommendations can be made regarding their eligibility for nomination to the National Register of Historic Places.

\section{Historic Sites}

Department of the Interior Regulations 36 CFR 60 provide for National registration of historic properties that:

A) are associated with events that have made a significant contribution to the broad patterns of our history; or

B) are associated with the lives of persons significant in our past; or

C) embody the distinctive characteristics of a type, period, or method of construction, or that represent the work of a master, or that possess high artistic values, or that represent a significant and distinguishable entity whose components may lack individual distinction; or

D) have yielded, or may yield, information important in prehistory or history.

In addition, the integrity of individual properties should be evaluated in relation to like properties with a similar cultural theme, within the same geographical area, and generally within the same time frame. For this study, historic properties were evaluated based on Criterion A: Agriculture, Criterion B: Important Individuals, Criterion C: Architecture, and Criterion D: Research Potential.

We assess three of the five historic component sites within the boundaries of Camp Swift (41BP105, 41BP148, 41BP430) as "not recommended for the National Register of Historic Places, and no further investigations are recommended. We assess one site (41BP138) and its associated dam and attached irrigation canal as "recommended for the National Register of Historic Places". Finally, recommendations are made on how best to protect an isolated grave (41BP146). 



\section{Table of Contents}

Management Summary $\ldots \ldots \ldots \ldots \ldots \ldots \ldots \ldots \ldots \ldots \ldots \ldots \ldots \ldots \ldots \ldots \ldots \ldots \ldots \ldots \ldots \ldots \ldots$

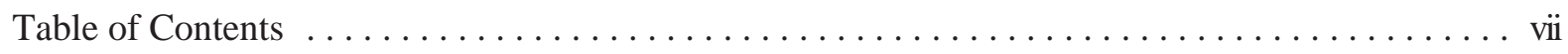

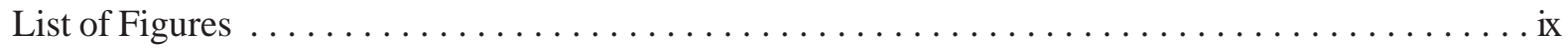

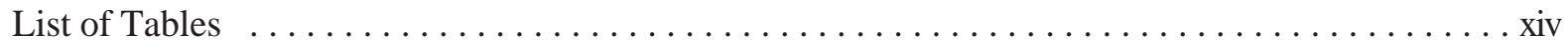

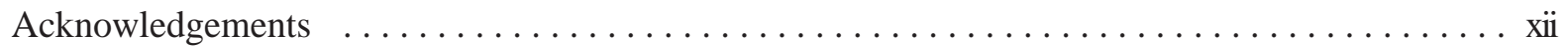

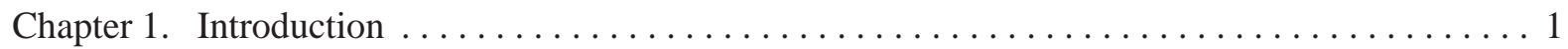

Chapter 2. Environment, Cultural Chronologies, and Previous Archaeology $\ldots \ldots \ldots \ldots \ldots .3$

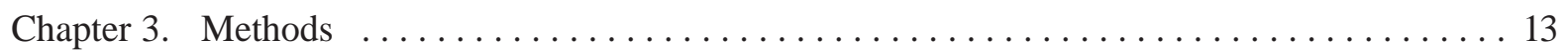

Chapter 4. Site Descriptions, Analysis, and Recommendations $\ldots \ldots \ldots \ldots \ldots \ldots \ldots$

Chapter 5. Historic Context and Research Design $\ldots \ldots \ldots \ldots \ldots \ldots \ldots \ldots \ldots \ldots \ldots \ldots$

Chapter 6. Summary and Recommendations $\ldots \ldots \ldots \ldots \ldots \ldots \ldots \ldots \ldots \ldots \ldots \ldots \ldots \ldots \ldots \ldots \ldots \ldots$

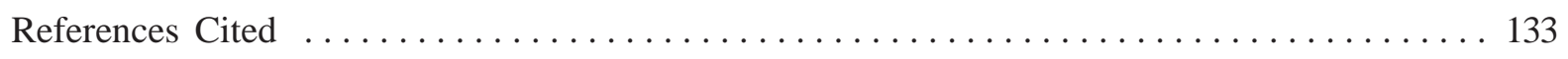

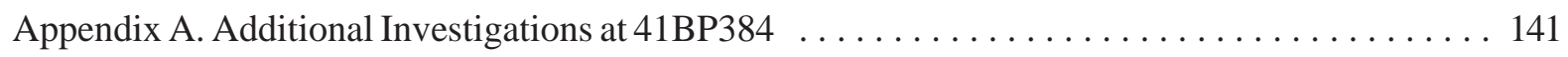

Appendix B. Combined USGS Map Showing Site Locations . . . . . . . . . . inside back cover 



\section{List OF Figures}

2-1 Location of Camp Swift within Bastrop County $\ldots \ldots \ldots \ldots \ldots \ldots \ldots \ldots$

2-2. Major drainages flowing through Camp Swift $\ldots \ldots \ldots \ldots \ldots \ldots \ldots \ldots \ldots \ldots$

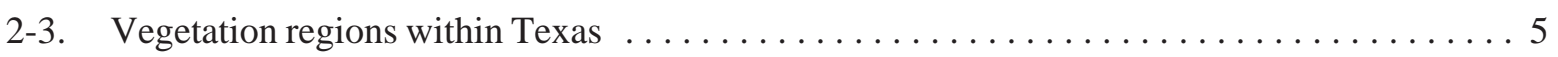

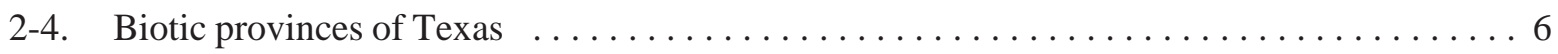

2-5. Cultural chronologies pertinent to the Camp Swift area $\ldots \ldots \ldots \ldots \ldots \ldots \ldots$

3-1. CAS crewmember Jimmy Barrera digging a shovel test and screening sediment at

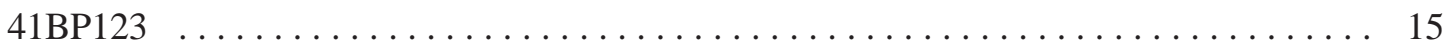

4-1. 41BP93 lies on a ridge and sideslope; facing north $\ldots \ldots \ldots \ldots \ldots \ldots \ldots \ldots \ldots \ldots \ldots$

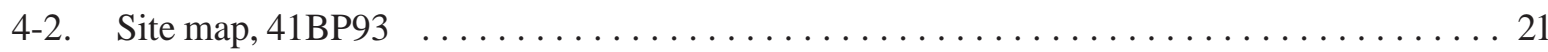

4-3. 41BP94 lies on an old field terrace at the confluence of an intermittent tributary and Big

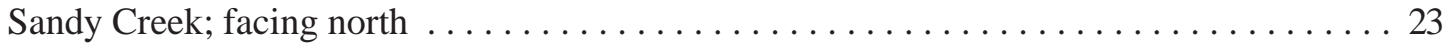

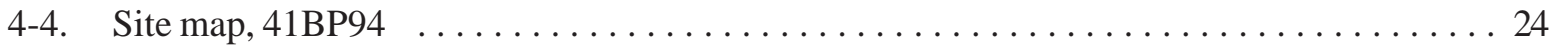

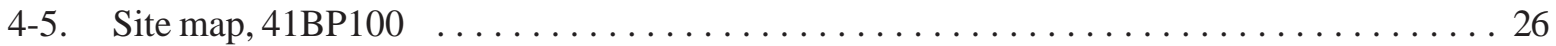

4-6. 41BP100 spans an old-field footslope adjacent to McLaughlin Creek; facing southwest . . 26

4-7. McLaughlin Creek at the southern edge of 41BP100; facing west . . . . . . . . . 27

4-8. Trench cut through the lower portion of 41BP100; facing southwest $\ldots \ldots \ldots \ldots \ldots 27$

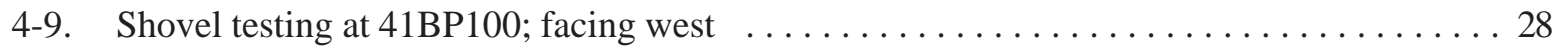

4-10. Scattered firecracked rock hearth feature lying on the bottom of a trench at 41BP100;

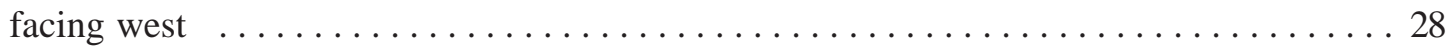

4-11. Distal tip of an arrow point collected from Shovel Test 3, 0-10 cm below the surface . . . 30

4-12. Sandy paste brownware sherd collected from the edge of the trench at 41BP100 $\ldots \ldots 30$

4-13. Shovel testing at 41BP105, a lower terrace site along Big Sandy Creek; facing west . . . 31

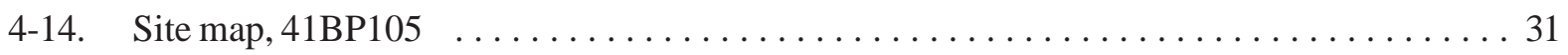

4-15. 41BP111 sets on a wooded ridge and sideslope; facing northwest $\ldots \ldots \ldots \ldots \ldots$

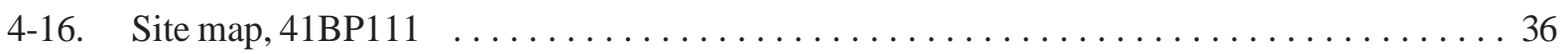

4-17. 41BP113 sets on an oldfield sideslope above McLaughlin Creek; facing west . . . . . . 37

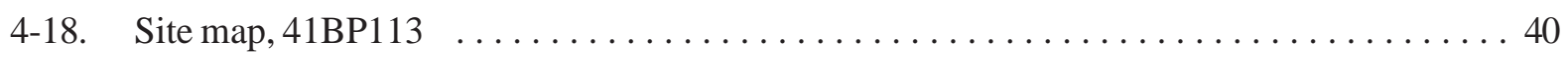

4-19. 41BP118 lies in an oldfield on a sideslope overlooking McLaughlin Creek; facing

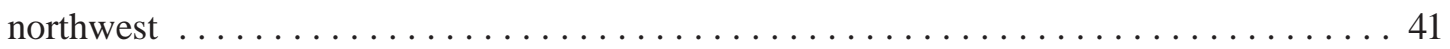

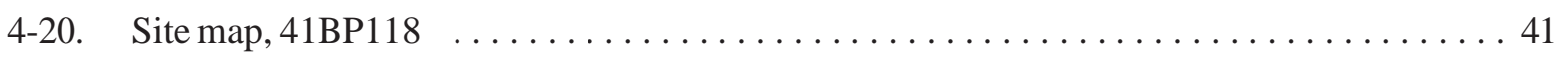

4-21. 41BP121 is situated on a gentle sideslope; photo taken facing north $\ldots \ldots \ldots \ldots .43$

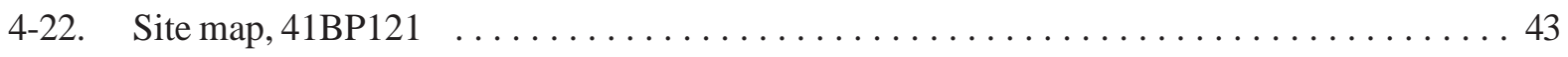


4- 23. 41BP123 sets on a wooded, gentle sideslope above a tributary of McLaughlin Creek;

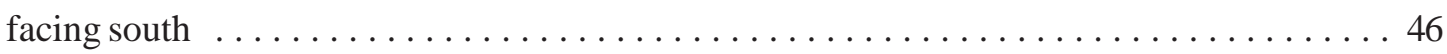

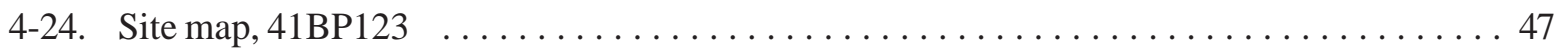

4-25. A lithic scatter was found at 41BP138, situated in an oldfield; facing west . . . . . 49

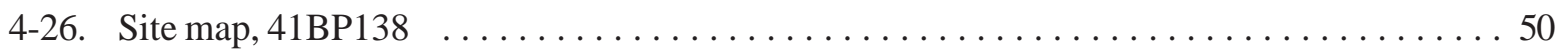

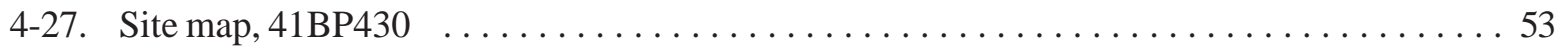

4-28. An ephemeral lithic scatter was found at 41BP430, on a historic farmstead situated

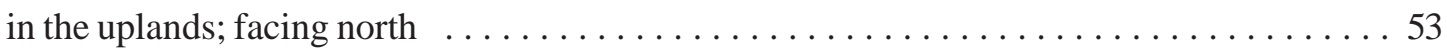

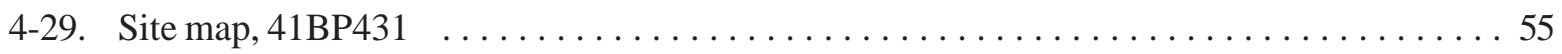

4-30. A road and pipeline are adjacent to 41BP431; facing south $\ldots \ldots \ldots \ldots \ldots \ldots$

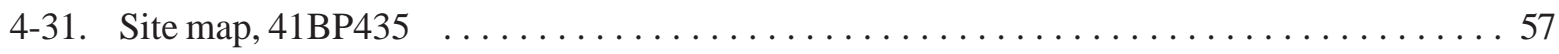

4-32. 41BP435 lies on a sideslope that has been artificially terraced for farming;

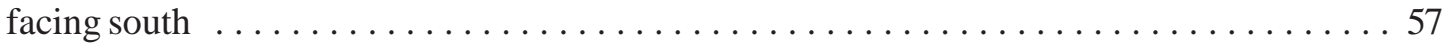

4-33. 41BP436 lies on a wooded sideslope; facing east $\ldots \ldots \ldots \ldots \ldots \ldots \ldots \ldots \ldots$

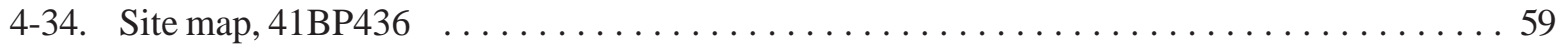

4-35. 41BP471 is a large, deeply buried open campsite located on a ridge and footslope;

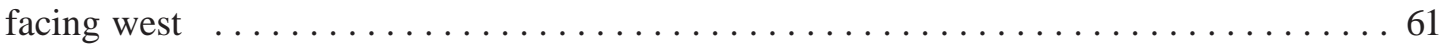

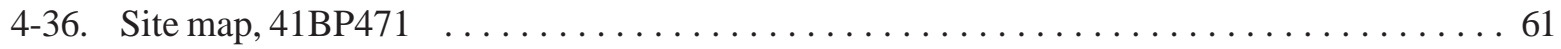

4-37. 41BP477 is a buried open campsite located on a ridge and footslope above an intermittent tributary of Big Sandy Creek; facing southwest . . . . . . . . . . . 64

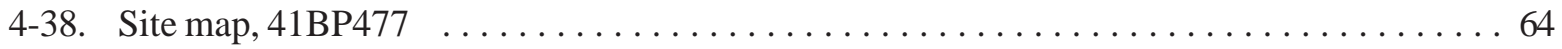

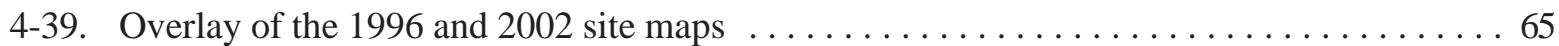

4-40. 41BP491 lies in a wooded upland setting, adjacent to 41BP495, a multi-component prehistoric open campsite; facing northwest $\ldots \ldots \ldots \ldots \ldots \ldots \ldots \ldots \ldots \ldots \ldots \ldots \ldots \ldots \ldots$

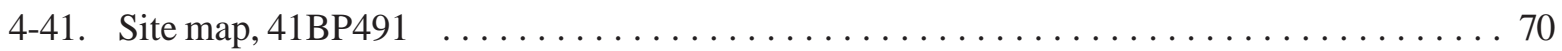

4-42. 41BP528 is situated on a wooded, gentle sideslope near an intermittent drainage;

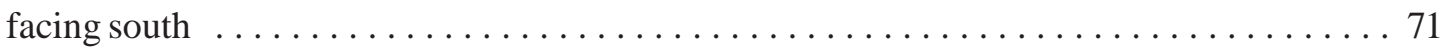

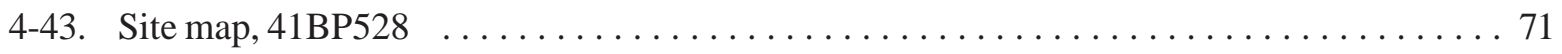

4-44. Aerial photograph with locations of sites and features included in the text $\ldots \ldots \ldots 73$

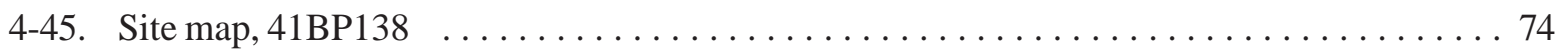

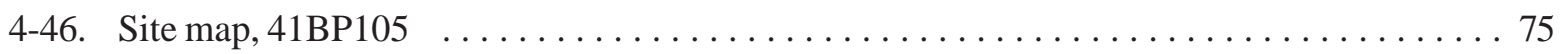


4-47. Grapevines cover the trees along the edges of Aussilloux's upper fields at 41BP105;

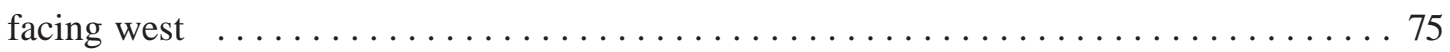

4-48. Remains of the cellar and first floor of Antoine Aussilloux's home; facing northeast . . . . 76

4-49. A few floor beams still remain; facing northwest $\ldots \ldots \ldots \ldots \ldots \ldots \ldots \ldots \ldots$

4-50. Debris-filled stone stairway leading from Aussilloux's cellar; facing north . . . . . . 77

4-51. Cellar and first floor wooden beams in Aussilloux's home; facing southwest . . . . . . 78

4-52. Stone-lined cistern adjacent to the corner of Aussilloux's home $\ldots \ldots \ldots \ldots \ldots \ldots$

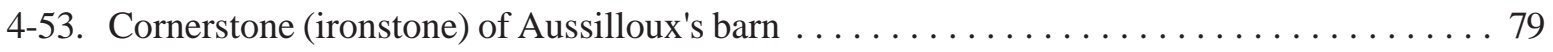

4-54. The Maker's mark on this ironstone sherd from a shallow saucer indicates it was manufactured in Staffordshire, England, perhaps as early as 1910 . . . . . . . . 79

4-55. A view toward Aussilloux's house (left of vehicle) and barn (right and beyond vehicle). This field was part of his 60 -acre purchase in 1876; (facing southwest) $\ldots \ldots \ldots \ldots 2$

4-56. Aussilloux's upper grape fields on a sideslope, near the confluence of Spring Branch

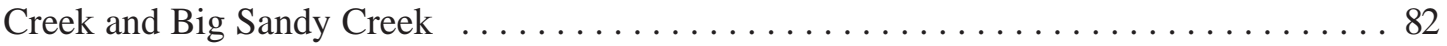

4-57. Aussilloux's lower grape fields on a lower terrace, near the confluence of Spring Branch

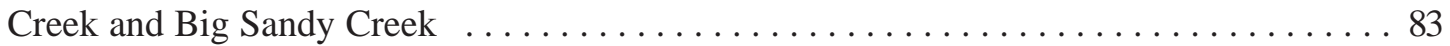

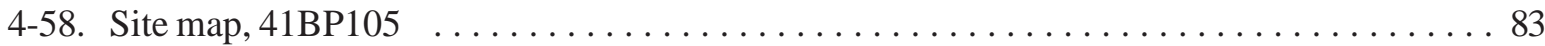

4-59. This stoneware sherd was found between $60-70 \mathrm{~cm}$ below the surface in Shovel

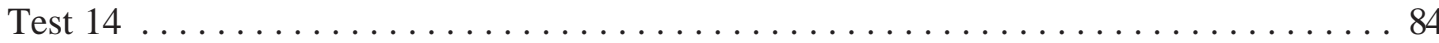

4-60. French engineer and winemaker Antoine Aussilloux constructed this sandstone dam over Spring Branch $($ Scott Falls Creek) around $1886 \ldots \ldots \ldots \ldots \ldots \ldots \ldots \ldots \ldots \ldots \ldots \ldots \ldots \ldots$

4-61. Away from the main course of the creek, Aussilloux used smaller sandstone blocks and slabs, with coarse mortared chinking; facing west $\ldots \ldots \ldots \ldots \ldots \ldots \ldots$

4-62. Note the drill bit markings in the upper right sandstone slab $\ldots \ldots \ldots \ldots \ldots \ldots \ldots$

4-63. This photo shows the opening on west end of Aussilloux's dam, with the white line indicating where a metal conduit was installed to direct the flow of water into an irrigation ditch. The ditch ended nearly .7 mile at his grape fields $\ldots \ldots \ldots \ldots \ldots 6$

4-64. Carved sandstone lining the grave $\ldots \ldots \ldots \ldots \ldots \ldots \ldots \ldots \ldots \ldots \ldots \ldots \ldots \ldots \ldots \ldots \ldots \ldots \ldots$

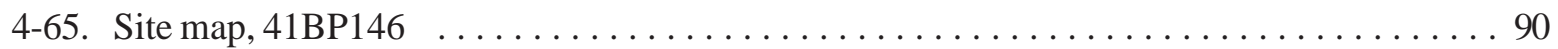

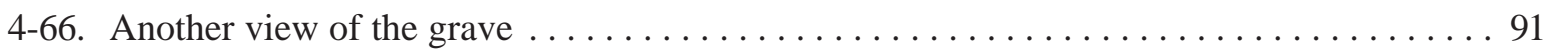

4-67. Aerial photograph of the Sayers Mine complex $\ldots \ldots \ldots \ldots \ldots \ldots \ldots \ldots \ldots \ldots \ldots \ldots$ 
4-68. Graded tipple leading from slope mine in operation from 1914-1924. Lignite from the mine carts was dumped into MK\&T railcars for transport to the main line $21 / 2$ miles southwest (Photograph from the Camp Swift historical files, AGTX-EV, Camp Mabry, Austin). . . . . . . . . . . . . . . . . . . . . . . . . . . . . . . 97

4-69. This upright tipple constructed over a vertical shaft was used from 1924-1928 to hoist lignite from below (Photograph from the Camp Swift historical files, AGTX-EV, Camp Mabry, Austin). . . . . . . . . . . . . . . . . . . . . . . . . . . . 98

4-70. Map of spoil pile area with concentration of artifacts alongside the railbed $\ldots \ldots \ldots 99$

4-71. A wash basin and brick were found near the railbed and spoil piles, along with

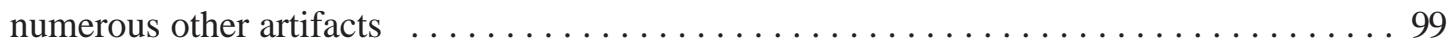

4-72. Lilies were growing in an area near the railbed, waste piles, and concentration of

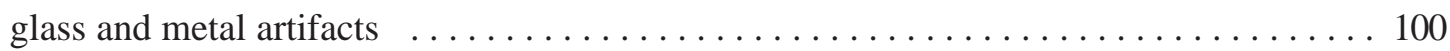

4-73. This slump pond at the end of the railroad bed is typical of many in the area $\ldots \ldots \ldots 100$

4-74. Concentrations of artifacts commonly associated with households were found in this area, which is the probable residence area for Mexican workers at the mine;

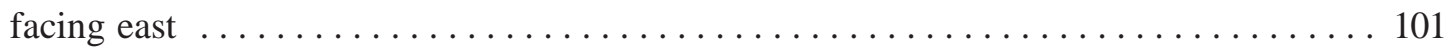

4-75. Map of artifact concentration areas and road traces through the residential area $\ldots \ldots 102$

4-76. Among other household items found in the residence area was this broken stove

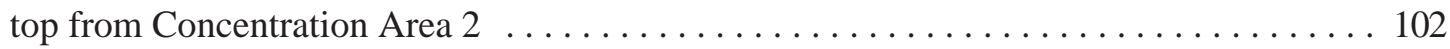

4-77. A few of the houshold and construction items found in Residence Concentration Area 1 were cut stone, a metal bucket piece, a large spoon, decorated kitchenware, a brown snuff bottle neck, a glazed stoneware rim sherd, a red brick, and clear glass

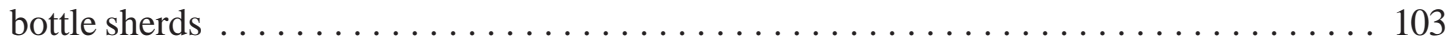

4-78. All that remains of the farmstead are scatttered artifacts, a depression where presumably the house stood, and a stonelined well; facing west $\ldots \ldots \ldots \ldots \ldots \ldots$

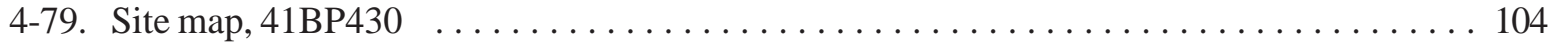

5-1. Sediment depositional units on Camp Swift (adapted in part from Prochnow 2001) . . . . 108

5-2. Range of mean shovel test depths within soil types for the 39 sites shovel tested in 2001, and the 18 sites shovel tested during this project

5-3. Minimum, maximum, and mean depths of shovel tests in varied settings; 39 sites tested in 2001 , and 18 during this project 
5-4. Ranges of mean depths of shovel tests within different settings $\ldots \ldots \ldots \ldots \ldots \ldots \ldots$

5-5. Volumetric distribution of chipped stone by setting $\ldots \ldots \ldots \ldots \ldots \ldots \ldots \ldots$

5-6. All chipped stone combined ( $\mathrm{n}=687$ ) versus clay depths for 35 sites on Camp Swift . . . 120

5-7. Minimum mean flake lengths for 35 sites in sandy loam and sand $\ldots \ldots \ldots \ldots \ldots 122$

6-1. Scott Falls Dam and Aussiloux's irrigation ditch; areas recommended off-limits are enclosed in bold "L" shape (at dam) and bold oval (east of Wine Cellar Road) . . . . 132 


\section{List OF TABLES}

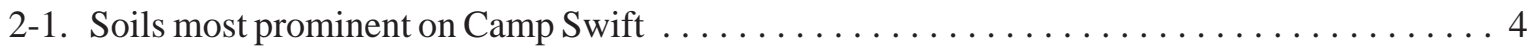

2-2. Common vegetation within various plant communities on Camp Swift $\ldots \ldots \ldots \ldots \ldots$

2-3. Mammals expected to either visit or inhabit the project area $\ldots \ldots \ldots \ldots \ldots \ldots \ldots$

2-4. Reptiles expected to either visit or inhabit the project area $\ldots \ldots \ldots \ldots \ldots \ldots \ldots \ldots$

2-5. Birds expected to either visit or inhabit the project area $\ldots \ldots \ldots \ldots \ldots \ldots \ldots \ldots$

4-1. Camp Swift site types evaluated during this project $\ldots \ldots \ldots \ldots \ldots \ldots \ldots \ldots \ldots \ldots \ldots \ldots$

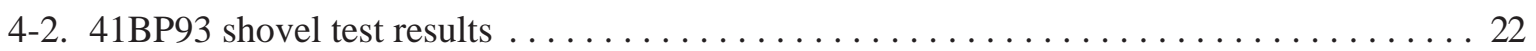

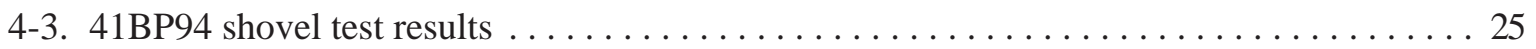

4-4. 41BP100 shovel test results . . . . . . . . . . . . . . . . . . . . . . 29

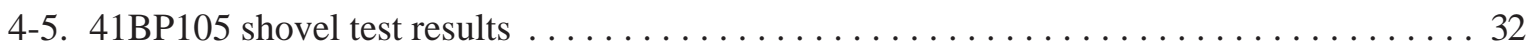

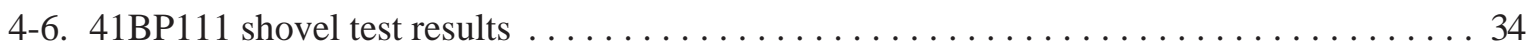

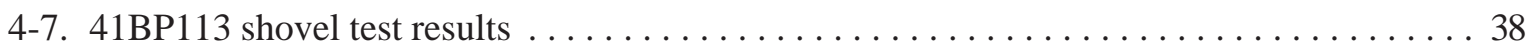

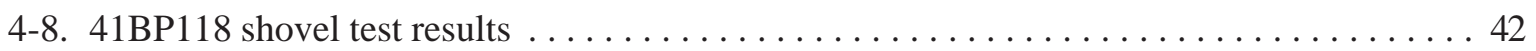

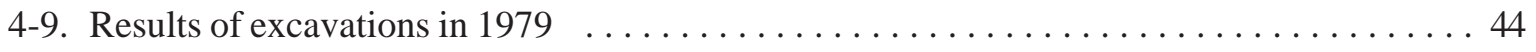

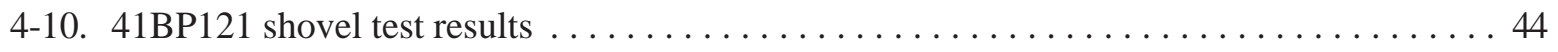

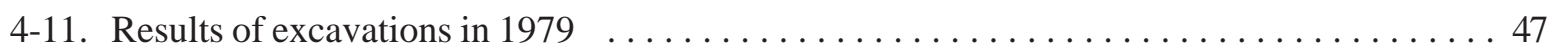

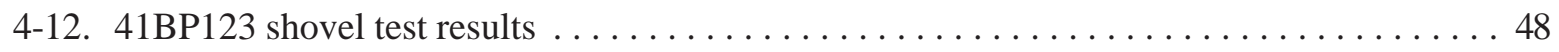

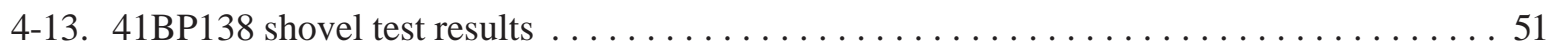

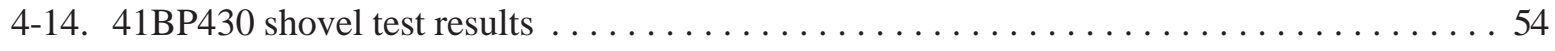

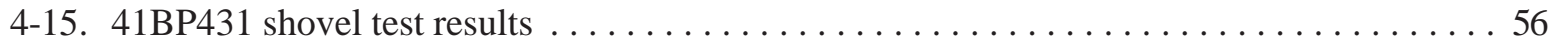

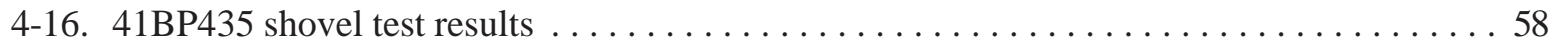

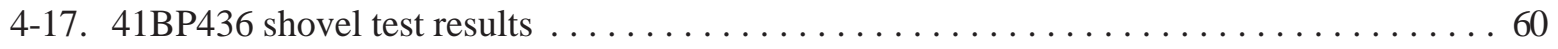

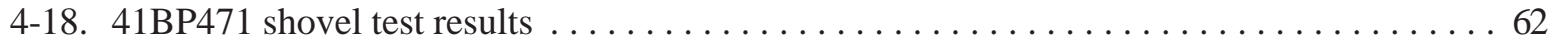

4-19. 41BP477 combined 1996 and 2002 shovel test results. 1996 ST data in this table are placed relative to their proximity to the 2002 STs (see Figure 4-39) $\ldots \ldots \ldots \ldots \ldots 66$

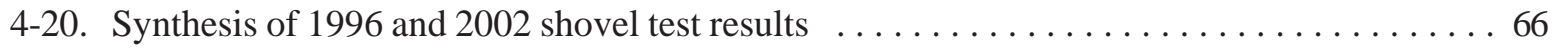

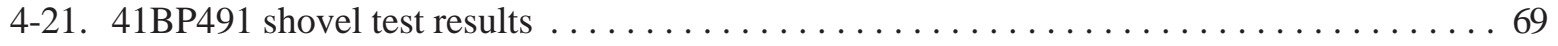

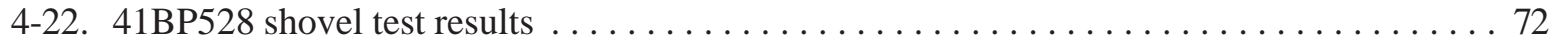

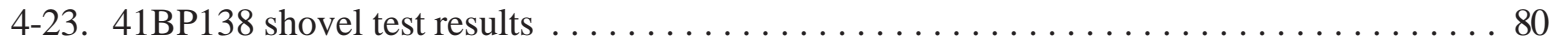

4-24. List of landowners on which the grave at 41BP146 is located $\ldots \ldots \ldots \ldots \ldots \ldots 2$ 
4-25. Surface inventory of spoil pile area adjacent to the railbed $\ldots \ldots \ldots \ldots \ldots \ldots \ldots$

4-26. Inventory of artifacts observed on the surface in the housing area in $2003 \ldots \ldots \ldots$

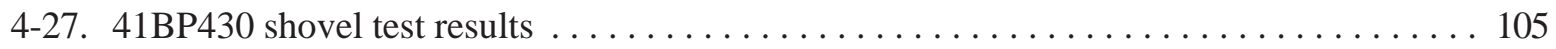

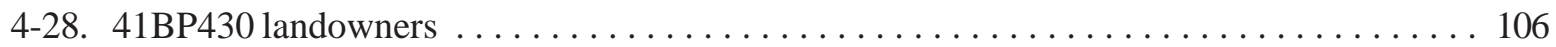

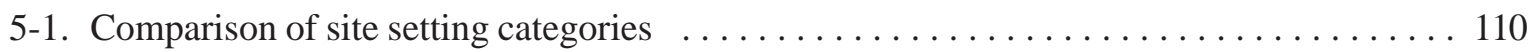

5-2. Cryptic characteristics of soils encountered during the 2001 and 2002-3 testing projects . 110

5-3. Results of shovel testing (2001 and 2002-3 projects) $\ldots \ldots \ldots \ldots \ldots \ldots \ldots \ldots \ldots \ldots$

5-4. Vertical volumetric distribution of chipped stone $\ldots \ldots \ldots \ldots \ldots \ldots \ldots \ldots \ldots \ldots$

5-5. Minimum mean lengths of complete flakes recovered from shovel tests during the 2001 and 2003 Camp Swift projects . . . . . . . . . . . . . . . . . . . . . . 121

5-6. Significance of 81 previously investigated prehistoric sites: significance relative to soil types

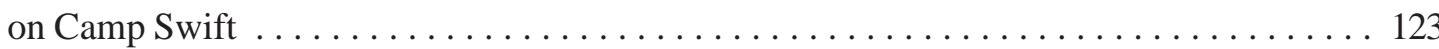

5-7. Our expectations based on our predictive model, and later determinations of significance

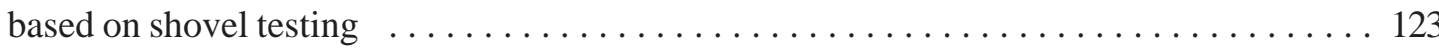

6-1. Prehistoric component sites assessed as having little or no integrity, or research potential; not eligible for the National Register of Historic Places . . . . . . . . . . . . . . . . . . . . 129

6-2. Prehistoric site components assessed as having moderate integrity, with the capability of demonstrating high integrity and research potential; further investigations are required . . . 130

6-3. Prehistoric site components assessed as demonstrating high integrity, with potentially high research potential; further investigations are required $\ldots \ldots \ldots \ldots \ldots \ldots \ldots \ldots$ 



\section{Acknowledgements}

The authors wish to thank Ms. Shellie Sullo, Cultural Resource Manager for the Texas National Guard who made this project possible and was extremely helpful throughout every phase. Also, the Camp Swift Facility Manager, Master Sergeant Robert West coordinated with us almost daily to ensure our testing project did not conflict with military training requirements. Throughout the project, Co-Principal Investigator Britt Bousman was extremely supportive and enthusiastic, and enjoined us in many stimulating discussions regarding site formation processes within the sandy mantle. The fieldwork was conducted by Project Archaeologist David Nickels, with Jimmy Barrera, Jackie Anzalone, Melissa Lehman, Shawn Soucie, and Antonio Padilla as crewmembers. The lithic analysis was conducted by Jimmy Barrera, Linda Hodges, Melissa Lehman, and Antonio Padilla. The person who fine tuned the maps and illustrations for this publication is Raphael Umsheid, and Karen Fustes and Melissa Lehman were the editors. Finally, under the direction of Connie Gibson, the artifacts, photographs and written documents were prepared for curation by Jimmy Barrera, Antonio Padilla, and Shawn Soucie. 



\section{Chapter 1}

\section{INTRODUCTION}

David L. Nickels

The Texas Army National Guard's Adjutant General's Department (hereinafter referred to as AGTX) owns Camp Swift, a military training facility near Bastrop, Texas. Camp Swift is located 8 miles north of Bastrop and 8 miles south of Elgin, in central Bastrop County. In its current configuration it comprises approximately 11,500 acres, reduced from its WWII era 52,982 acres. The land is now used for tracked and wheeled vehicle maneuvers, as well as dismounted (on-foot) military training.

\section{Project Background}

The Adjutant General's Department of Texas' Environmental Resources Management Office is charged with oversight management of archaeological compliance for Camp Swift. This testing project was undertaken to meet requirements under Sections 106 and 110 of the National Historic Preservation Act (NHPA). The National Register of Historic Places (NRHP) and the Advisory Council for Historic Preservation (ACHP) were created by the NHPA. Under Sections 106 and 110 of the NHPA, the protection of cultural resources is related to their eligibility for inclusion in the National Register of Historic Places (NRHP), which is in turn dependent on their NRHP significance as defined in 36 CFR Part 60. The National Historic Preservation Act Amendments of 1992 clarified Section 110 and directed federal agencies to estab- lish preservation programs corresponding to their activities and effects on historic properties. Under Section 110, federal agencies may evaluate the significance of cultural resources not currently threatened to assist with the development of preservation planning. The federal regulatory process is described in detail in 36 CFR Part 800. Section 106 specifies that the NHPA must be given the opportunity to comment on those cultural resources (in this case, archaeological sites) that may be eligible for listing on the NHRP. In turn, the State Historic Preservation Officer (SHPO) at the Texas Historical Commission - Department of Antiquities Protection (THC-DAP) advises the Texas National Guard regarding their obligations under Sections 106 and 110. In compliance with the fore mentioned laws and regulations, The Texas $\mathrm{Na}-$ tional Guard has developed an Integrated Cultural Resource Management Plan (ICRMP) for its installations, including Camp Swift. It is under the guise of the fore mentioned laws, regulations, and the ICRMP for Camp Swift that this testing project was undertaken.

This report documents the results of limited shovel testing in December 2002 and January 2003 to re-evaluate and map archaeological sites on Camp Swift to be affected directly or indirectly by the military training. During a series of surveys beginning in 1979, 169 archaeological sites were documented. Of those 169, 59 have been recom- 
mended as requiring further testing on various levels (Mauldin 2001). In November and December 2002, the Center for Archaeological Studies (CAS) of Texas State University-San Marcos (TxSU-SM) shovel tested 39 of the 59 sites, and subsequently conducted unit excavations on 20 of the 40 in the summer of 2002 (Nickels et al. 2003a, b). The 40th site is now on property that had been sold to a private landowner, and was not revisited.

In December 2002 and January 2003, CAS fulfilled a contractual agreement with AGTX to conduct an intensive cultural resources inventory on the remaining 19 sites recommended for reevaluation. A total of 267 shovel tests were placed on 17 of those sites. An additional 44 shovel tests were placed around 41BP138, an historic winery operation. Finally, additional mapping and inventories were conducted at two sites: 1) 41BP148, a mining operation and residential area, and 2) 41BP146, an isolated historic burial. The completion of this project finalizes the listing of sites that required further testing, mapping, and reevaluation (see Mauldin 2001:181; Category 6 Sites).

\section{Report Organization}

This report is divided into a total of 6 chapters, including this introductory chapter. An overview of the environment, cultural chronologies, and previous archaeology is presented in Chapter 2. Chapter 3 presents the field and laboratory methodolo- gies employed during the project and intended to address the cultural contexts and issues for the prehistoric and historic sites tested. Chapter 4 provides a site-by-site description, the levels and results of work conducted, followed by the conclusions and recommendations for each site individually. The historic context, research design, and issues addressed during this project are in Chapter 5 , and finally, a project summary and overall recommendations are presented in Chapter 6.

Appendix A provides a brief summary of additional shovel testing conducted on 41BP384, a site previously tested in 2001 (Nickels et al. 2003). Appendix B is a combined USGS Quadrangle map showing the site locations.

In addition to these project and site specific data sets, Texas archaeological site forms were updated for all 20 sites recorded in the project area. These are available at the Texas Archaeological Research Laboratory in Austin. 


\section{Chapter 2}

\section{Environment, Cultural Chronologies, and Previous Archaeology}

David L. Nickels

\section{Introduction}

This chapter contains an overview of the environment, cultural chronologies, and previous archaeology in the region and on Camp Swift. A more comprehensive description is contained in Nickels et al. 2003.

\section{Camp Swift's Modern Environment}

CampSwiftis located in northcentral Bastrop County (Figure 2-1) approximately $30 \mathrm{~km}$ east of the Balcones Escarpment. Its terrain consists of rolling uplands and ridges, associated slopes, and bottomlands along both steady and intermittent streams. Deeply incised and mostly intermittent streams flow through the Camp, eventually emptying into the Colorado River (Figure 2-2).

\section{Geology and Soils}

Light gray to yellowish brown mudstone and sandstone beds withcommonironstone inclusions underlie the more recent sedi- ments and soils on Camp Swift (Barnes 1974). The soils are classified as alfisols in the uplands and slopes, and entisols or mollisols on the floodplains and terraces (Baker 1979).

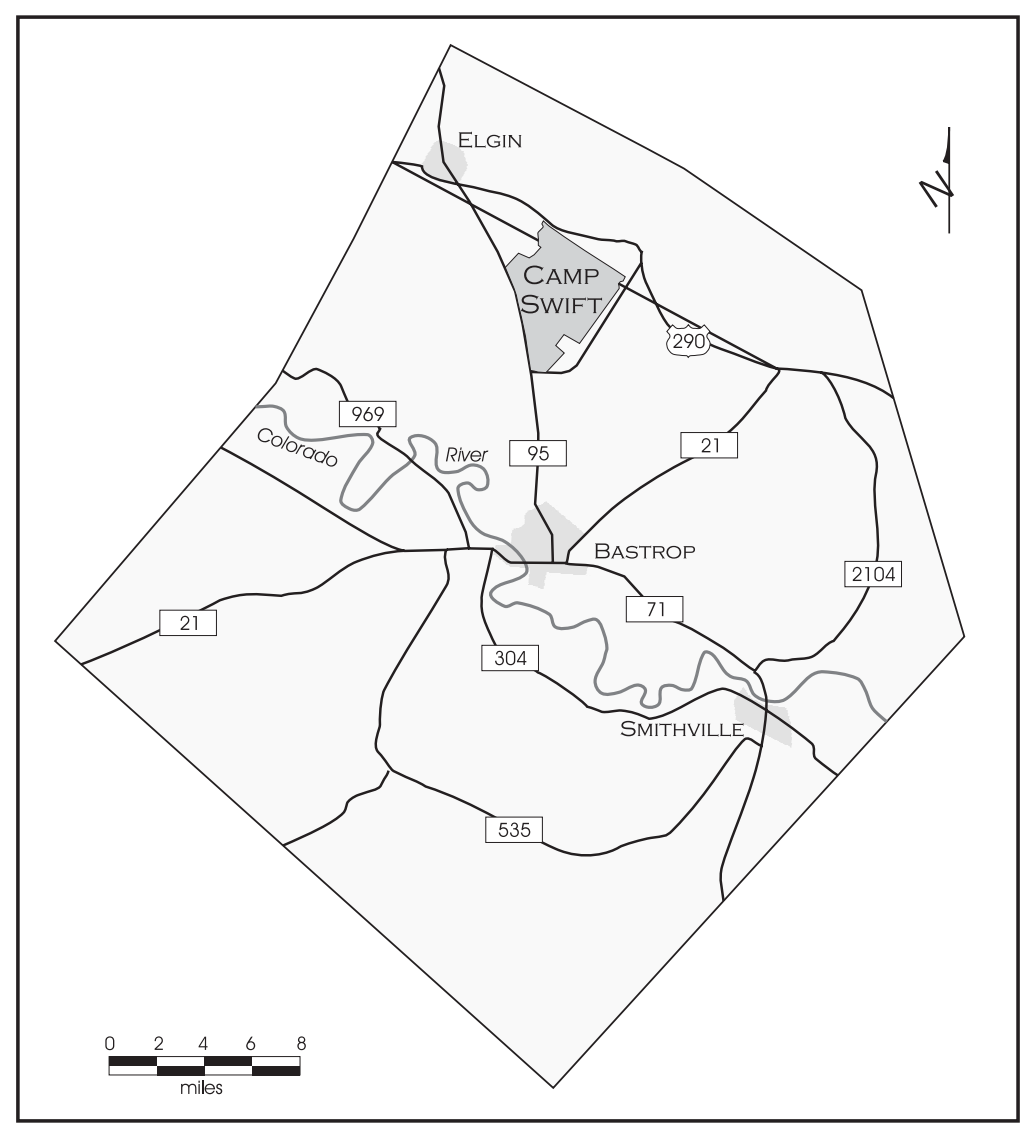

Figure 2-1. Location of Camp Swift within Bastrop County. 


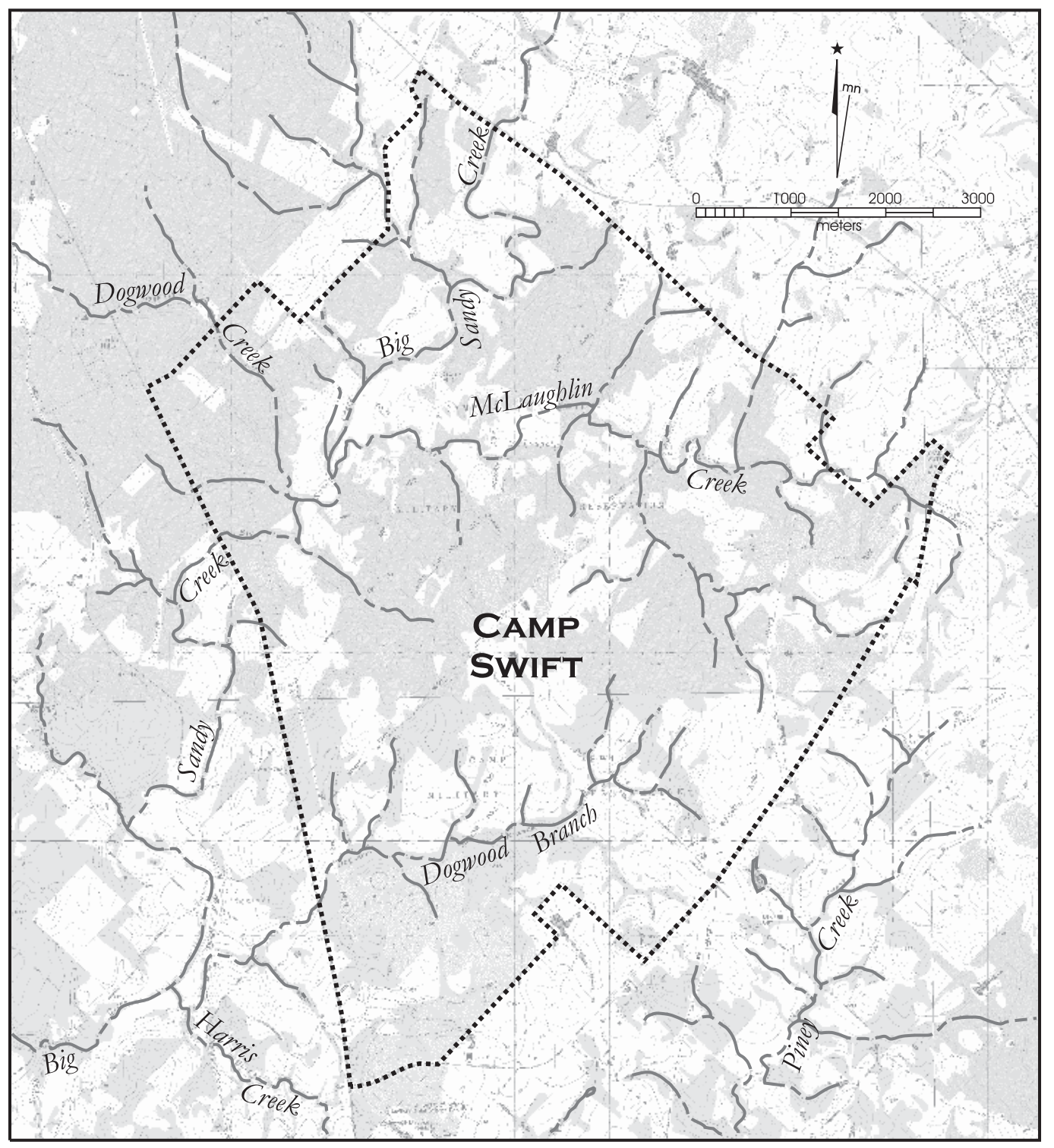

Figure 2-2. Major drainages flowing through Camp Swift.

Table 2-1. Soils most prominent on Camp Swift.

\begin{tabular}{|l|l|l|}
\hline \multicolumn{1}{|c|}{ Soils } & \multicolumn{1}{|c|}{ Settings } & \multicolumn{1}{|c|}{ Surface Textures } \\
\hline Axtell series & Stream terraces and uplands & Fine sandy loam \\
\hline Demona series & Ridgetops, sideslopes, upland drainageways & Loamy fine sand \\
\hline Patilo series & Uplands & Fine sand \\
\hline Siltsid series & Uplands & Loamy fine sand \\
\hline Tabor series & Broad uplands & Fine sandy loam \\
\hline Gowen series & Floodplains, Bottomlands & Clay loam \\
\hline Sayers series & Floodplains, Bottomlands & Fine sandy loam \\
\hline
\end{tabular}




\section{Flora and Fauna}

Camp Swift is situated within the Post Oak Savannah vegetation region of Texas (Gould 1975) stretching from northeast Texas, southwesterly along the base of the Balcones Escarpment (Figure 2-3). Table 2-2 presents the most common vegetation within plant communities.

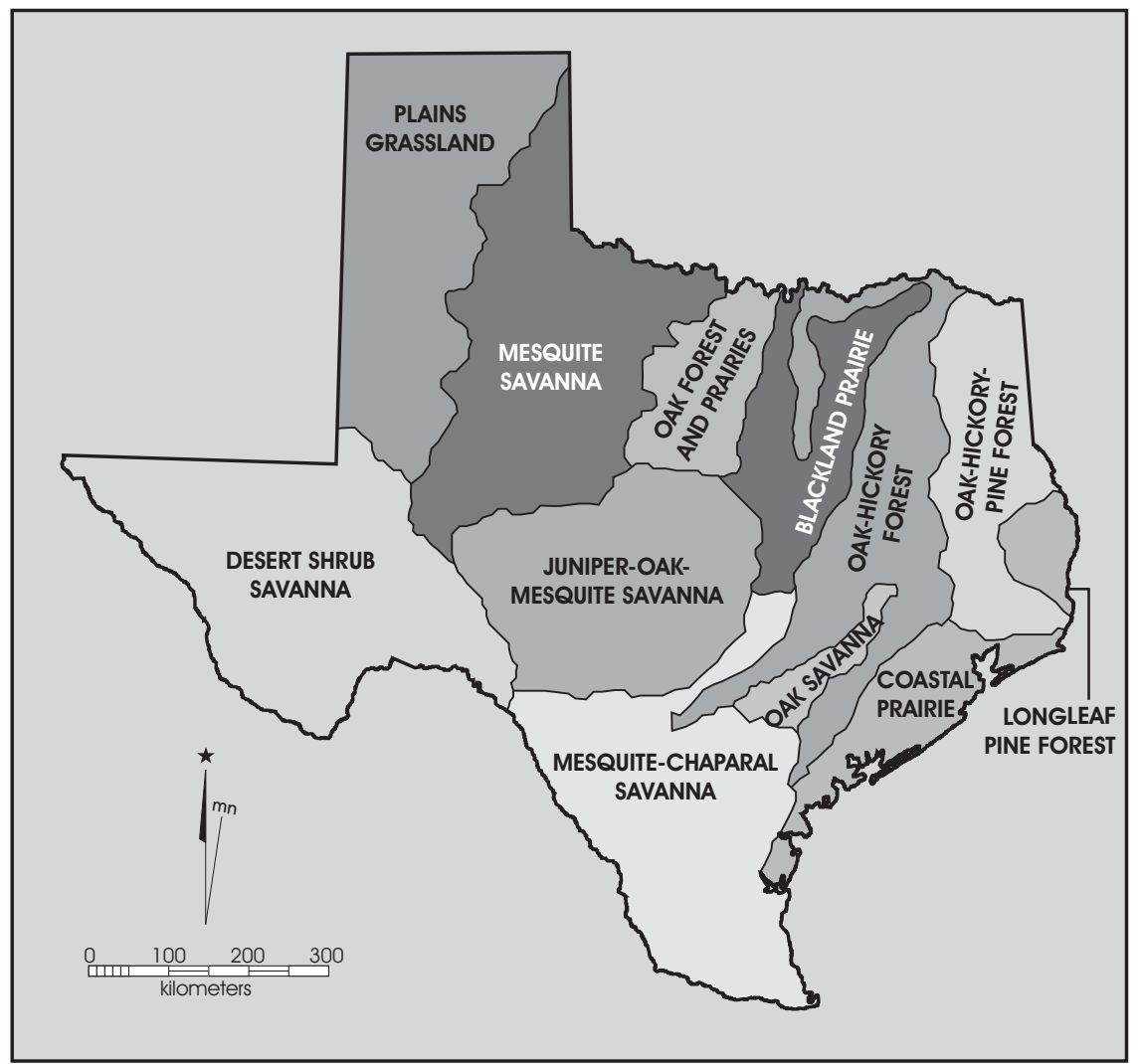

Figure 2-3. Vegetation regions within Texas (Gould 1975).

Table 2-2. Common vegetation within various plant communities on Camp Swift (Tera Corporation 1978; adapted from Skelton and Freeman 1979).

\begin{tabular}{|l|l|l|}
\hline \multicolumn{1}{|c|}{ Plant Community } & \multicolumn{1}{|c|}{ Vegetation } & \multicolumn{1}{c|}{ Settings } \\
\hline Post Oak-Red Cedar Woodlands & Post oaks, red cedar & $\begin{array}{l}\text { Upper valley margins, upland } \\
\text { divides, sandy soils }\end{array}$ \\
\hline Mesquite Brushland & $\begin{array}{l}\text { Mesquite, red cedar, netleaf } \\
\text { hackberry, winged elm }\end{array}$ & $\begin{array}{l}\text { Disturbed slopes and knolls, soils } \\
\text { eroded to clay }\end{array}$ \\
\hline Old Field & Grasses, weeds & $\begin{array}{l}\text { Floodplains, lower valley margins, } \\
\text { thick sand }\end{array}$ \\
\hline Riparian & $\begin{array}{l}\text { Red cedar, black willow, elm, } \\
\text { cottonwood, black hickory, pecan, } \\
\text { pot oak, hackberry }\end{array}$ & Floodplains \\
\hline
\end{tabular}




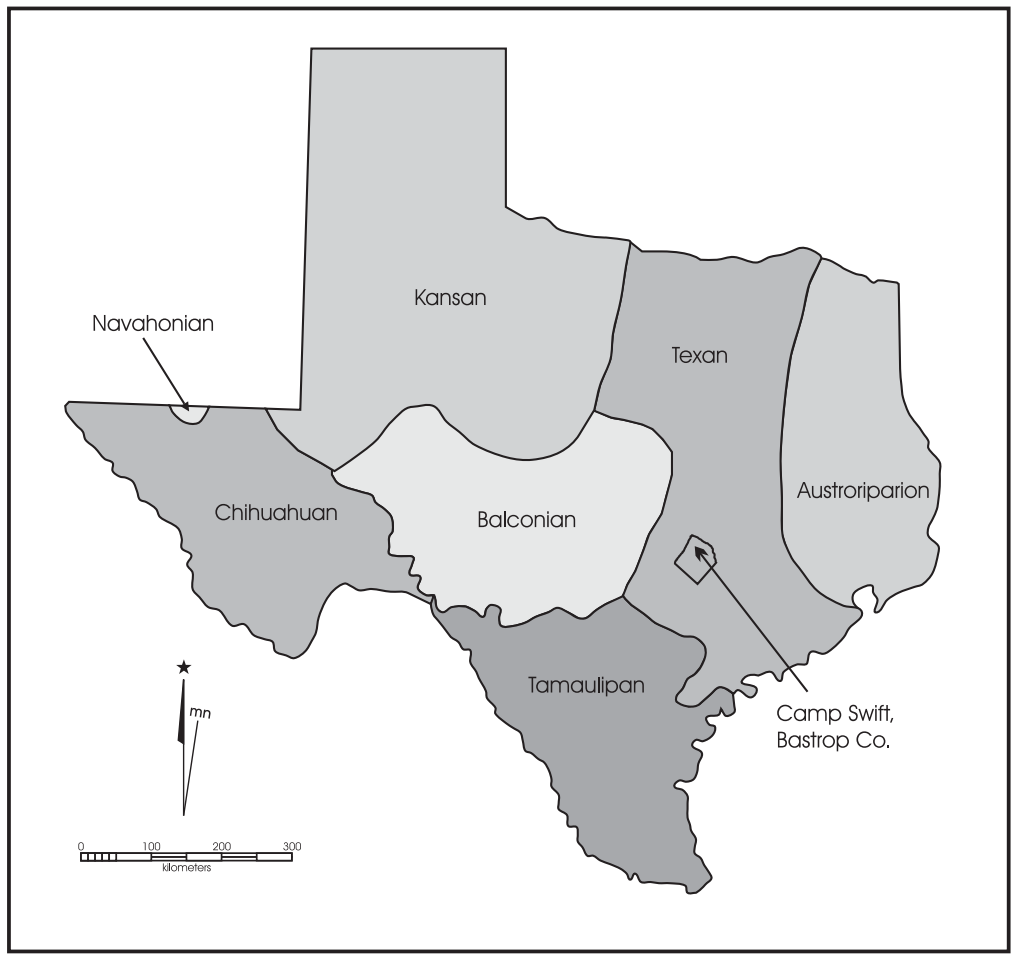

Figure 2-4. Biotic provinces of Texas (Blair 1950).
Camp Swift lies within the Texan biotic province (Figure 24) as defined by Blair (1950). As with the wide variety of flora that exists within the 11,500-acre project area, there also exists a very diverse animal population. Those likely to either migrate through the area, or make it their permanent habitat (Tera Corporation 1978; Nightengale and Moncure 1996) are shown in Tables 2-3 through 2-5.

\section{Climate}

Bastrop County has a subtropical humid climate, with cool winters and hot summers. The coolest month is January, with a mean temperature of $40 \mathrm{o} \mathrm{F}$, and the warmest is July, with a mean maximum of $96^{\circ} \mathrm{F}$. The annual mean precipitation is $36.82 \mathrm{inches}$. All these factors

Table 2-3. Mammals expected to either visit or inhabit the project area.

\begin{tabular}{|l|l||l|l|}
\hline \multicolumn{1}{|c|}{ Common Name } & \multicolumn{1}{c||}{ Scientific Name } & \multicolumn{1}{|c|}{ Common Name } & \multicolumn{1}{|c|}{ Scientific Name } \\
\cline { 2 - 2 } white tailed deer & Odocoileus virginianus & black tailed jackrabbit & Lepus californicus \\
\cline { 2 - 2 } coyote & Canis latrans & striped skunk & Mephitis mephitis \\
\cline { 2 - 2 } grey fox & Urocyon cinereoargenteus & eastern cottontail & Sylvilagus floridanus \\
\cline { 2 - 2 } bobcat & Lynx rufus & plains pocket gopher & Geomus bursarius \\
\hline raccoon & Procyon lotor & spotted ground squirrel & Spermophilus spilosoma \\
\hline opossum & Didelphis virginiana & Piñon mouse & Peromyscus truei \\
\hline grey squirrel & Sciurus carolinensis & nine-banded armadllo & Dasypus novemcinctus \\
\hline wild hog & Sus scrofa & cougar & Felis concolor \\
\hline Hispid cottonrat & Sigmodon hispidus & Fulvous harvest mouse & Reithrodontomys fulvescens \\
\hline white-footed mouse & Peromyscus leucopus & & \\
\hline
\end{tabular}


Table 2-4. Reptiles expected to either visit or inhabit the project area.

\begin{tabular}{|c|c|c|c|}
\hline Common Name & Scientific Name & Common Name & Scientific Name \\
\hline $\begin{array}{l}\text { western diamondback } \\
\text { rattlesnake }\end{array}$ & Crotalus atrox & $\begin{array}{l}\text { broad-banded } \\
\text { copperhead }\end{array}$ & $\begin{array}{l}\text { Agkistrodon } \\
\text { contortrixnlaticinctus }\end{array}$ \\
\hline checkered garter snake & $\begin{array}{l}\text { Thamnophis marcianus } \\
\text { marcianus }\end{array}$ & Great Plains skink & Eumeces obsoletus \\
\hline yellow mud turtle & Kinosternon flavescens & western cottonmouth & $\begin{array}{l}\text { Agkistrodon piscivorus } \\
\text { leucostoma }\end{array}$ \\
\hline $\begin{array}{l}\text { eastern yellow belly } \\
\text { racer (blue racer) }\end{array}$ & $\begin{array}{l}\text { Coluber constricter } \\
\text { flaviventris }\end{array}$ & ornate box turtle & Terrapene ornate \\
\hline $\begin{array}{l}\text { common snapping } \\
\text { turtle }\end{array}$ & Chelydra serpentina & red eared slider & $\begin{array}{l}\text { Trachemys scritpta } \\
\text { elegans }\end{array}$ \\
\hline
\end{tabular}

Table 2-5. Birds expected to either visit or inhabit the project area.

\begin{tabular}{|l|l||l|l|l|}
\hline \multicolumn{1}{|c|}{ Common Name } & Scientific Name & Common Name & Scientific Name \\
\hline scissor-tailed flycatcher & Muscivora forficata & red tailed hawk & Buteo jamaicensis \\
\hline red-bellied woodpecker & Centurus carolinus & western meadowlark & Sturnella neglecta \\
\hline Carolina chickadee & Parus carolinensus & American robin & Turdus migratorius \\
\hline brown thrasher & Toxostoma rufum & northern mockingbird & Mimus polyglottos \\
\hline painted bunting & Passerina ciris & lark sparrow & Chondestes grammacus \\
\hline turkey vulture & Cathartes aura & mourning dove & Zenaidura macroura \\
\hline northern bobwhite & Colinus virginianus & greater roadrunner & Geococcyx californianus \\
\hline northern cardinal & Cardinalis cardinalis & & \\
\hline
\end{tabular}

combined allow for an annual growing season of 206 days (Bastrop County 2002).

\section{Cultural Chronologies}

Because of its location, Camp Swift could have been influenced by the Central, East, and Upper Coastal cultural regions of Texas (Goode 1989). Therefore, the cultural chronologies from all these regions are addressed. Figure 2-5 provides the approximate dates and cultural markers generally associated with the prehistory of these regions. All dates shown in Figure 2-5 and given in the following discussion in years before present (B.P.), i.e, before A.D. 1950, when radiocarbon dating was refined and fully accepted as valid.

\section{Paleoindian}

This period spans the period estimated at between ca. 11,500-8800B.P.in Central Texas (Collins 1995:381-383), 12,000-7,000 B.P. in Southeast 
Texas (Patterson 1995), and between 11,500-7950 in the Pineywoods of northeast Texas (Perttula 1995). The Paleoindian period began toward the close of the Pleistocene. Diagnostic artifacts of the early Paleoindian interval include Clovis andFolsom projectile points, with the first stemmed (as opposed to lanceolate) points, Angostura, Wilson, Golondrina, St. Mary's Hall, and Barber (among a few others) appearing during the late Paleoindian interval. In Southeast Texas, Patterson (1995:252) notes that "There are considerable data to indicate that San Patrice and Early Side-Notched were the principal point types in Southeast Texas during the Early Paleoindian period."

Small bands of nomadic, big-game hunters followed herds of Late Pleistocene fauna, including mammoth, mastodons, bison, camel, and horse, across North America (Black 1989b). They also exploited a wide diversity of plants and animals used for subsistence by these early Americans (Black 1989b), such as turtles and tortoises, alligators, mice, badgers, and raccoons (Collins 1995:381; Collins and Brown 2000). Known Clovis sites include killsites, quarries, caches, open campsites, ritual sites, and burials (Collins 1995:381-383). The Folsom interval follows Clovis, and Folsom artifacts are fairly common in Central and South Texas; however, no campsites or killsites have been found south of a large workshop, Pavo Real (41BX52), in Bexar County (Hester 1995:434435).

With the possible exception of Berclair Terrace (although not dated; Sellards 1940), archaeological evidence suggests the decline and extinction of mammoth, mastodon, horse, camel, and giant bison (Bison antiquus) after 8000 B.P. Human hunters were forced to concentrate on deer, antelope, and other medium-size or smaller game.
Changes in the subsistence base required technological shifts that mark the beginning of a new cultural period known as the Archaic.

\section{Early Archaic}

Collins (1995:383) dates the Early Archaic from 8800 to 6000 B.P. in Central Texas, and Patterson (1995) posits that the period covers approximately 2,000 years, from 7000 to 5000 B.P. in Southeast Texas. In East Texas, the Archaic interval begins around 7950 B.P (Perttula 1995). While the basic hunter-gatherer adaptation probably remained intact, more intensive exploitation of local and smaller resources in central Texassuch as deer, fish, and plant bulbs - is indicated by greater densities of ground-stone artifacts, firecracked rock cooking features, and more specialized tools (Turner and Hester 1999:246, 256). Early Archaic groups were likely small and highly mobile (Weir 1976; Story 1985), exploiting such year-round resources as prickly pear and lechugilla, as well as rodents, rabbits, and deer (Story 1985:38).

\section{Middle Archaic}

Collins (1995:383) defines this intermediate interval of the Archaic as lasting from about 60004000 B.P. in central Texas, and Patterson (1995) believes the 1,500 years between 5000 and 3500 B.P. represents this period in Southeast Texas. The Middle Archaic perhaps continued through about 3000 B.P. in Northeast Texas (Perttula 1995; Story 1990). As the climate became moister, deer and acorn thrived in Central Texas. Those resources along with nut trees in the riverine environments of the Balcones Escarpment attracted groups at least seasonally, from all other regions of Texas (Black 1989b; Hall 1998; Story 1985:40; Weir 1976:125, 128). 


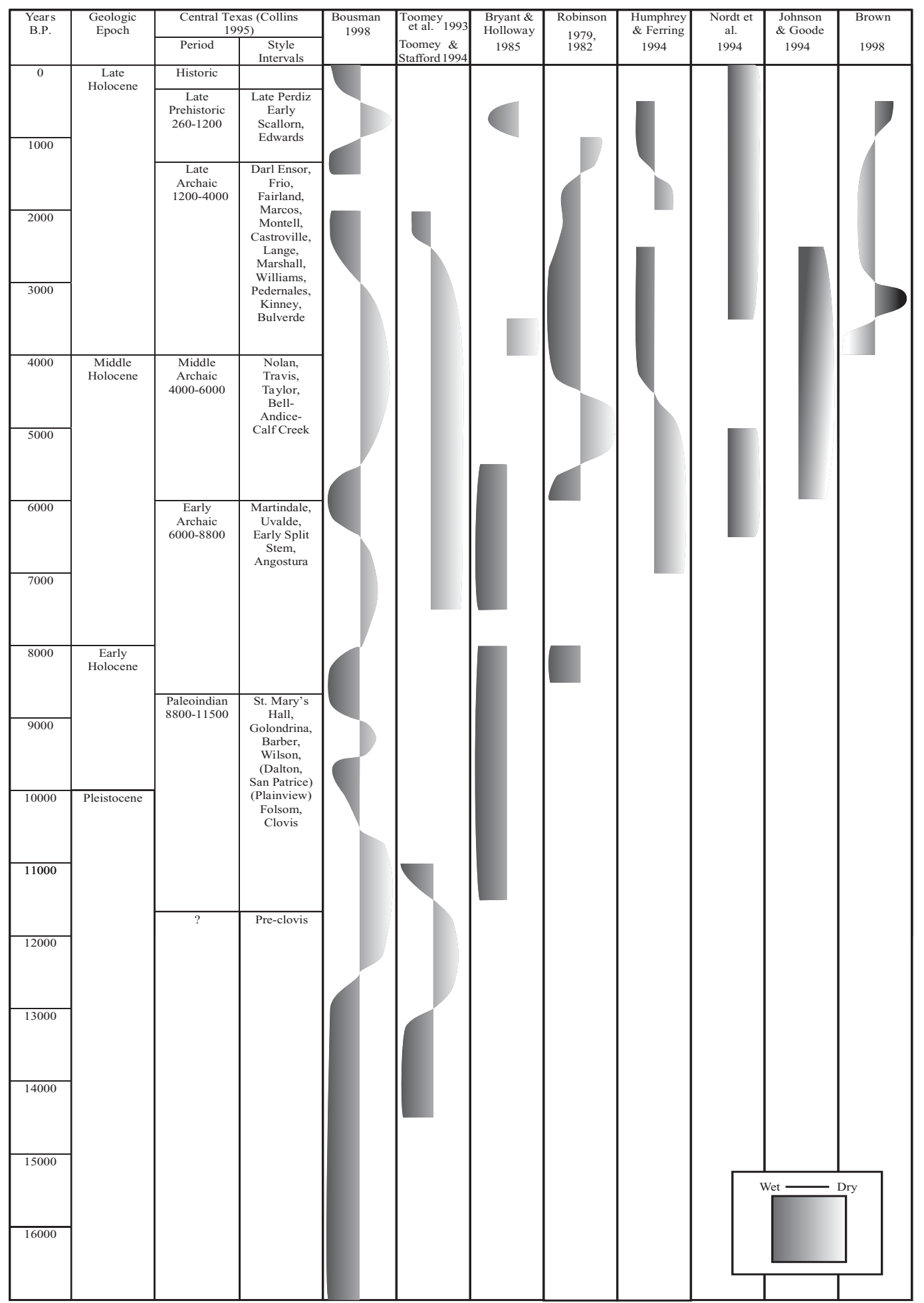

Figure 2-5. Cultural chronologies pertinent to the Camp Swift area. 
The widely scattered bands prevalent in the Early Archaic now began to coalesce into larger groups who shared the intensive work of gathering and processing plants and acorns (Weir 1976:126). Some researchers believe burned rock middens formed after many repeated cooking events of these resources (Creel 1986; Prewitt 1991; Weir 1976); however, the exact processes which formed these middens are still a matter of controversy (e.g., Black et al. 1997; Leach and Bousman 1998; Mauldin et al. 2003).

In addition to burned rock middens, Middle Archaic sites consist of open campsites, and lithic processing sites; and cemeteries make their first appearance during this period, suggesting a movement toward less mobility and perhaps territorialism

\section{Late Archaic}

Collins (1995:384) dates the final interval of the Archaic in Central Texas to approximately 4000-800 B.P. The Late Archaic opens approximately the same time period in the Pineywoods, but in Southeast Texas, it represents the Early Ceramic period, about 3500-1400 B.P. (Patterson 1995). Subsistence during the Late Archaic is assumed to have become less specialized in favor of a broad spectrum subsistence base (Black 1989a:30) By about 1450 B.P., bison had again disappeared (Dillehay 1974). Late Archaic populations in Central Texas were increasing and becoming more territorial (Story 1985:44-45). The most common diagnostic stone tools of this period are Ensor and Frio types (Turner and Hester 1999:114,122).

\section{Late Prehistoric}

The term "Late Prehistoric" is commonly used to designate the period following the Late Archaic
Texas in Central Texas, and is generally thought of as spanning the period 1200-420 B.P. (Collins 1995). Two distinct phases recognized within the Late Prehistoric in Central Texas are the Austin and Toyah. The most prevalent point found in Austin phase sites is the Scallorn arrow point. Cemeteries from this period often reveal evidence of conflict (Black 1989a:32; Prewitt 1974:46).

The beginning of the Toyah phase is marked by the introduction of Perdiz and Cliffton arrow points, double-pointed and beveled knives, gravers, small drills, stone side-scrapers, expedient scrapers, crude bifaces, bison bone scrapers, deer bone spatulates, bone awls, Leon Plain and possibly intrusive pottery, ground stone, hematite pigment, worked mussel shells, smoothed antler tines, pendants, tubular bone beads, fishhooks, and needles, along with perishable wood and grass/ mat items (Jelks 1962: 86-90).

\section{Protohistoric/Historic}

The Protohistoric period begins in 1528 when Spanish explorer Cabeza de Vaca traversed parts of southeast Texas and left a diary of his five years spent traveling among the hunter-gatherers of Texas and northern Mexico (Covey 1961). In 1542, Coronado entered the Texas Panhandle with hopes of finding riches (Winship 1896); the same year, after assuming command from Hernando de Soto, Spanish explorer Luis de Moscoso Alvarado ventured into northeast Texas and encountered Caddoan-speaking groups before turning back. In 1568, Englishman David Graham returned from Mexico to Nova Scotia passing inland along the Texas Gulf Coast (Cutrer 1985:7-12).

The period between de Vaca's written account and the advent of Spanish missions around San Antonio and east Texas in the late 1600s and early 
1700s is referred to as the Protohistoric; a time when few, scant written documents exist detailing Native American life outside the missions. The Historic period then, is generally thought of as beginning in the 1700s. Collins (1995:386-387) offers that the Historic period then begins ca. 260 B.P. in Central Texas.

The Historic period is best documented by the records of Spanish priests in charge of the missions, and in order to either inspect the missions or its politically fragile frontier, the Spanish launched several expeditions into New Spain (Texas). Early Spanish entradas through Bastrop County include Those of Domingo Teran de los Rios in 1691, Pedro de Aguirre in 1709, and Louis Juchereau St. Denis in 1714. In 1804, a small Spanish fort named Puesta de Colorado was built at the Camino Real crossing on the Colorado River (Leffler 2001).

By 1827, Mexico had gained its independence from Spain and European settlers were moving into the Bastrop area in Stephen F. Austin's "Little Colony". However Indian depredations impeded further westward settlement toward the Camp Swift area until around 1836, when Texas gained its independence from Mexico and Texas Rangers offered better protection (Leffler 2001). Although peace was declared under a treaty with the Comanche in 1845, continued Indian depredations occurred to Euroamerican settlers in the area who took farm and ranchlands that were once hunting grounds (e.g., Wilbarger 1985).

\section{Recent Archaeological Research}

As of the 7th of February 2003, there were 597 prehistoric and historic sites registered in Bastrop County, and there are 168 known sites within the Camp. Although a review of survey reports indicates that 169 sites were documented, one of those
(41BP383) is on land that has been sold by the Guard, and is now on private property.

Skelton and Freeman (1979), contracted by the Lower Colorado River Authority, surveyed approximately 4,000 acres of the Camp in 1979 and documented 83 sites. Between 1994 and 1997 staff archaeologists with the Texas National Guard's Cultural Resources Office surveyed selected areas of the Camp and documented an additional 14 sites. In 1995, Espey Huston and Associates conducted two surveys, finding 7 new sites on each survey; one for proposed seismic exploration lines (Schmidt and Cruse 1995), and one for a proposed electrical transmission line (Nash et al. 1995). In 1997, Robinson and others (2001) surveyed an additional 3,000 acres and resurveyed 1,000 acres previously covered by Skelton and Freeman (1979); an additional 58 sites were recorded. In 2000, staff archaeologists with the Center for Archaeological Research at the University of Texas at San Antonio relocated 28 selected sites, GPS'd their locations, conducted limited shovel testing on two sites, and excavated 12 backhoe trenches for a geomorphological study (Robinson et al. 2001).

In November and December 2001, CAS relocated, shovel tested, and mapped 39 sites that had been recommended for further testing (Mauldin 2001). As a result of shovel testing, CAS determined that 20 of the 39 should be evaluated with 1$\mathrm{x}-1-\mathrm{m}$ excavation units (Nickels et al. 2003). During the summer of 2003, CAS returned to those 20 sites and excavated 120 units (not yet reported). During the current project CAS relocated, mapped, and re-evaluated the remaining 19 sites on the Camp that had been identified as needing additional Phase I testing or mapping (Mauldin 2001:181).

Site types located within the confines of the 11,500-acre Camp include prehistoric campsites, 
lithic scatters and lithic procurement sites, along with historic military structures related to WWII, farmsteads, homesteads, cemeteries, foundation

footings, stock tanks, barns, fences, and corrals. 


\section{Chapter 3}

\section{Methods}

David L. Nickels

\section{Introduction and Scope of Work}

The methods employed during this project mirror those of a similar project conducted by CAS at Camp Swift in 2001, during which time 39 sites were shovel tested, mapped, and evaluated. The current project (2002-2003) involved relocating, shovel testing, and mapping 20 previously recorded archaeological sites. CAS conducted a limited surface collection strategy focused on temporally diagnostic artifacts, and dug 311 shovel tests on 18 of the 20 sites. A 5-person crew who were in the field in December 2002 and January 2003 accomplished the fieldwork in 5-day shifts. The artifacts were returned to the Texas Army National Guard, and the records and other materials recovered or generated during the fieldwork and subsequent laboratory analysis are curated at the Texas Archeological Research Laboratory, Austin.

\section{Prefield Planning}

Prior to initiation of actual fieldwork, more detailed archival research, soil survey, geology and topographic maps, and aerial photographs were used to better understand the sites we were to evaluate. Before the project began the Principal Investigators met with Ms. Shellie Sullo from the Texas Army National Guard's Cultural Resources Office to refine fieldwork and reporting standards.
To insure systematic recording procedures, the coprincipal investigator/project archaeologist met with each crewmember before the fieldwork began to review artifact classifications and recording procedures.

Reports of previous surveys conducted were reviewed, and a copy of a report of recommendations and conclusions synthesizing these various surveys at Camp Swift (Meissner 2001) was examined in detail. In addition, a review was conducted of the current literature for the North, Central and Northeast Texas Archaeological Regions. Prehistoric sites could be defined as open campsites, villages, lithic procurement sites, lithic scatters, or Native American burials. Open campsites often contain varying quantities of fire-cracked rock from possible small-hearth features and a lithic scatter, suggesting an occupational episode. Villages could be identified by either stacked stone or pit depressions, generally associated with ground stone and/or Native American ceramics. Lithic procurement sites are those characterized by the presence of lithic raw materials; often this consisted of exposed gravels. Exploitation of the exposure is indicated by light to heavy scatters of chipped stone debris, including artifacts such as cores, quarry blanks, preforms, flakes, and (rarely) informal or formal tools. Native American burials most probably will not be marked and are often discovered either in an erosional context from 
cutbanks, or around disturbed rock cairns or low earthen mounds. CAS would not disturb Native American human remains if they were encountered. Upon locating such a site, CAS personnel would avoid further impacts to that location, and would immediately notify the AGTX staff archaeologist.

Our research also indicated that log cabins, farmsteads, water wells, shaft and open pit mines, trash dumps, isolated graves, cemeteries, and early historic trails, roads and bridges are the types of historic sites that could exist within the area.

\section{Fieldwork}

The fieldwork was conducted by staff archaeologists under the direct supervision of the projects' co-Principal Investigator. The fieldwork consisted of mapping, limited surface collecting, and shovel testing. In adhering to a limited collection policy, only possibly diagnostic prehistoric and historic artifacts were collected from the surface. CAS archaeologists dug 311 shovel tests and collected all shovel test cultural material.

\section{Documenting Sites}

In some cases sites were easily relocated based on their plots on topographic maps. To find other sites, the project relied heavily on a hand-held Trimble global positioning system (GPS) receiver to relocate archaeological sites that in some cases had not been relocated since 1979 , and were heavily overgrown. Universal Transverse Mercator(UTM) coordinates obtained from site Trinomial forms were entered as waypoints in the GPS before going to the field, and were used in the field to navigate to the sites. Once a site was relocated, crewmembers intensively examined the ground surface, flagged artifacts if any, and noted any high-density con- centrations. After the location was confirmed as a site, boundaries were initially established according to surface artifact distribution. Later, as shovel testing confirmed the presence/absence of subsurface cultural material, the boundary was expanded accordingly. Crewmembers then rotated through the various tasks of properly documenting the site. Notes were made regarding site disturbance, vegetation, features and pertinent landmarks visible from the site datum.

To establish the site datum, a large nail was hammered into a tree at the site's center or the best vantage point. USGS 7.5' topographic maps and a Trimble Geo Explorer III Global Positioning System (GPS) were used to determine UTM coordinates. In addition to taking a reading from the datum of the site, CAS surveyors took a GPS reading of all features such as hearths, roads, and fences, and from enough points along the perimeter to define the estimated site boundary. This data was differentially corrected and GPS software-generated site maps were plotted by CAS staff every evening while still in the field to check for complete and accurate data.

\section{Shovel Tests}

CAS personnel conducted shovel tests at each site (less 41BP146 and 41BP148) to test for subsurface cultural materials and examine the geomorphology (Figure 3-1). They excavated a sufficient number of shovel tests within the site to determine the vertical extent of the archaeological deposit, the vertical extent and severity of disturbance present, and to develop a preliminary understanding of the nature of the soils and depositional history at the site. The project archaeologist determined the number of shovel tests, taking into consideration site size, artifact frequency over the site surface, and topographical variation over the 
site surface. The results were then analyzed to evaluate the potential for buried, intact cultural deposits below cultural material exposed on the surface.

Shovel test locations and excavation units were not precisely recorded during the previous surveys, and none could be positively relocated during this project. Thus, each site was treated as though it had not been previously tested.

All shovel test locations were recorded using a hand-held Trimble Geo Explorer III Global Positioning Systems (GPS). A shovel test was defined as a 30-cm diameter unit, excavated, screened, collected, and recorded in levels no more than 10 $\mathrm{cm}$ in thickness to a standardized depth of at least $50 \mathrm{~cm}$, unless bedrock or culturally sterile sediments were encountered. Additional levels were removed if artifacts were encountered in what would be the standard bottom 10-cm level, and the potential for subsurface cultural strata was deemed high, as in alluvial or thicker, sandy sediments. In deep, sandy soils, shovel tests were generally terminated between 70 and $140 \mathrm{~cm}$ below the surface. All sediment was screened through 1/4inch wire mesh and the results of shovel tests recorded on standardized forms. All artifacts from shovel tests were collected, bags were labeled with their appropriate field provenience and transported to CAS for analysis and temporary curation.

\section{Site Mapping and Photography}

Site maps, showing site boundaries, datum locations, shovel tests, sampled areas, collected items, features, areas of high artifact density, and physical features on the landscape were recorded.

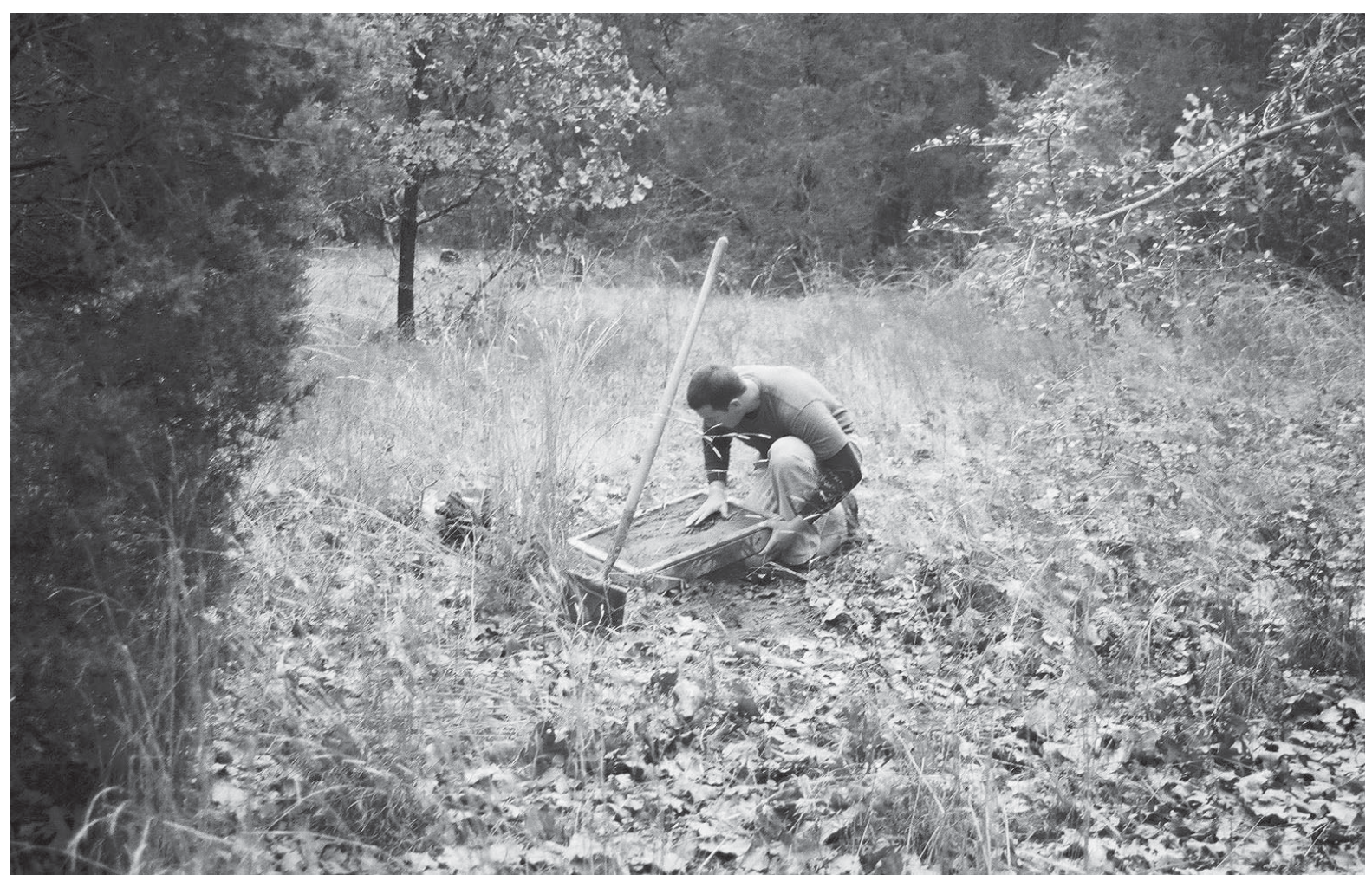

Figure 3-1. CAS crewmember Jimmy Barrera digging a shovel test and screening the sediments at 41BP123. 
A field sketch map using a pace-and-compass method was prepared, while mapping data was being collected using the GPS. Landforms, roads, or streams that would be helpful in relocating the site were also shown.

Archival quality 35-mm black-and-white prints, and $35-\mathrm{mm}$ color prints and slides were made of all sites, features and artifacts where appropriate. CAS staff took 109 photographs using primarily color print and slide film, using a Canon camera with zoom lense. Photographs were recorded on standard CAS photo forms in the field. In addition to photographing general site evaluation and excavation activities, particular attention was given to features such as hearths.

\section{Laboratory Methods}

A temporary CAS laboratory was established in Bastrop, Texas where artifacts and forms were accounted for daily. Upon returning to San Marcos, cultural materials recovered during the project were inventoried at the CAS-SWT laboratory. All artifacts were then identified and analyzed. Lot numbers were assigned to artifacts in the lab. Artifacts and samples were separated by artifact type and recovery context to facilitate analysis. Processing of recovered artifacts began with washing and sorting into appropriate categories. These data were entered into an Excel spreadsheet.

At the CAS lab all cultural material collected was prepared for storage in accordance with federal regulation $36 \mathrm{CFR}$ part 79, and in accordance with current guidelines of the Texas Archeological Research Laboratory. Lithic, metal, and ceramic artifacts processed in the CAS laboratory were washed, air-dried, and stored in archival-quality bags. Acid-free labels were placed in all artifact bags. Each bag was labeled with a provenience or corresponding bag number. Artifacts larger than a dime, and all tools were labeled with permanent ink and covered by a clear coat of acrylic. Other artifacts were separated by class and stored in acidfree boxes with standard labels.

\section{Site Forms and Maps}

The information recorded in the field as well as preliminary analysis data derived in the lab were transferred to TexSite software "revisit" forms for filing with TARL. Site and artifact data used in analyses were provided in database form compatible with Microsoft Excel. In addition to the general maps in this report, an additional sets of maps of the project area were prepared for the Texas National Guard. These show the locations and site boundaries for all cultural resources in the inventory plotted on 7.5' Series USGS quadrangles.

\section{Chipped Stone Analysis}

Chipped stone pieces could be categorized functionally as projectile points, preforms, drills, perforators, unifaces, and scrapers. The single projectile point fragment found was assigned to a type based on the commonly accepted point typology developed for Central Texas (e.g. Turner and Hester 1999), but also considering numerous published reports from the surrounding regions.

The category of scraper was determined based upon not only function, but also degree of retouch. Unifaces and bifaces that had been formally fashioned or shaped, and exhibited late stage, systematic sharpening and /or resharpening were categorized as scrapers.

Other pieces were categorized in terms of stage of reduction, such as cores, tested cobbles, quarry blanks, other bifaces, unifaces, and interior 
or exterior flakes. Quarry blanks are generally a thick, bifacially reduced to a middle stage, but can have some cortex remaining. Presumably they are reduced to make them easily transportable to areas where raw material is scarce (e.g., Nickels et al. 1997; Nickels 2000:120-121). Other nondiagnostic bifaces include those in all stages of reduction that do not fit elsewhere. For purposes of this inventory, unifaces are flakes that have been modified, either expediently or moderately. Thus, the degree of retouch that could be determined macroscopically was considered. Expedient flake tools are those that have been utilized or have been minimally retouched, with no apparent attempt at shaping. Moderately retouched flakes are those that have been flaked to create an edge, but with no formal shaping.

\section{Curation}

Finally, all cultural material, field notes, forms, photographs, and drawings, along with a copy of this report on acid-free paper, and computer disks pertaining to this project are stored in acid-free boxes at TARL. 



\title{
Chapter 4
}

\section{Site Descriptions, Analysis, And Recommendations}

\author{
David L. Nickels and Melissa L. Lehman
}

\section{Introduction}

This chapter provides a general description of the sites, and an analysis of the associated artifacts found during this project. Twenty sites were relocated and mapped. Eighteen of the twenty were shovel tested. Fifteen of the twenty sites have prehistoric components only, three have both a prehistoric and historic component, and two have historic components only (Table 4-1). The prehistoric-component sites are discussed in Section I, followed by the historic component sites in Section II. As a matter of clarity, when discussing the level of effort and results of investigations at each site, we frequently refer to the work of Robinson and others conducted in 1997. Although the work was done in 1997, the results were actually published in 2001, and thus can be found in "References Cited" as Robinson et al. 2001.

Two versions of this publication are available. At the request of the Texas Army National Guard, Adjutant General's Environmental Resources Office, site locations are not included in this chapter; they are shown on a topographic map inserted into an envelope on the inside cover of this publication.

\section{Site Types and Artifact Categories}

\section{Prehistoric}

Traditionally, prehistoric site types classified as either open campsites, lithic procurement sites, and lithic scatters were identified during the surveys. Open campsites were identified by the presence of intact burned rock features or scattered fire cracked rock, evidence of late stage reduced lithics, and a wide variety of either chipped or ground stone tools. In some cases an open campsite had a combination of all three; in some cases a single hearth or scattered burned rock with only a few flakes was also typed as an open campsite. The key factor in classifying a site as an open campsite was the presence of burned rock. Lithic procurement sites were identified on the basis of evidence that gravel deposits were used as a source of raw material. Within the gravels should be evidence of early stage reduction in the form of tested cobbles, minimally scarred cores, and large exterior flakes, and possibly quarry blanks broken during manufacture. Lithic scatters were typed based on the absence of campsite features and material, but with the presence of cores and flakes regardless of stages of reduction, possibly crudely flaked bifaces broken during manufacture, and possibly discarded broken tools. 


\section{Historic}

Early historic settlement in the region would be represented by wooden or stone above-ground structures. Later industrial operations included lignite and clay mining. In these contexts, historic properties could be typed as mines, open pits, associated mine structures and constructed features, farmsteads, trash dumps, and individual burials or cemeteries. Isolated properties could include windmills, wells, cattle pens and dipping vats, and irrigation ditches to name a few. exposed in many areas in the central and western portions of the site. There is a gravel outcrop located approximately $20 \mathrm{~m}$ north, and there are two open areas to the east and west. The nearest natural water source is McLaughlin Creek, approximately $100 \mathrm{~m}$ to the south. Disturbances observed included a bladed trail, a fence post, and five military foxholes. Surface visibility was approximately 60 percent.

Table 4-1. Camp Swift site types evaluated during this project

\begin{tabular}{|c|c|c|c|c|c|}
\hline Site & Prehistoric & Historic & Site & Prehistoric & Historic \\
\hline BP93 & Open Campsite & & BP146 & & Grave \\
\hline BP94 & Open Campsite & & BP148 & & Mining Operation \\
\hline BP100 & Open Campsite & & BP430 & Lithic Scatter & Farmstead \\
\hline BP105 & Open Campsite & Vineyard Field & BP431 & Open Campsite & \\
\hline BP111 & Open Campsite & & BP435 & Open Campsite & \\
\hline BP113 & Open Campsite & & BP436 & Open Campsite & \\
\hline BP118 & Open Campsite & & BP471 & Open Campsite & \\
\hline BP121 & Open Campsite & & BP477 & Open Campsite & \\
\hline BP123 & Open Campsite & & BP491 & Open Campsite & \\
\hline BP138 & Lithic Scatter & Winery & BP528 & Open Campsite & \\
\hline
\end{tabular}

\section{Section I: Prehistoric Site Components}

\section{$41 B P 93$}

\section{Description}

41BP93 (Figures 4-1 and 4-2) is a 4,975- $\mathrm{m}^{2}$ prehistoric open campsite ranging in elevation from 420 to 430 feet. The site is situated on a wooded knoll and sideslope above the floodplain of McLaughlin Creek. Patilo complex (PaE) and Silstid loamy fine sand $(\mathrm{SkC})$ cover the area and support scattered stands of oak, cedar, and open grasslands. The sandy loam soil is generally shallow, and the underlying red and orange clays were

\section{Levels of Work and Results}

When the site was originally recorded in 1979 (Skelton and Freeman), six small interior flakes, one flake core, and a few small fragments of firecracked limestone were recovered during shovel testing. In 2002, CAS-SWT personnel excavated nineteen shovel tests and collected two bullets, five small ( $<1 ")$ pieces of firecracked rock, 3 larger $(>1 ")$ pieces of firecracked rock, one utilized flake, and two exterior flakes (Table 4-2). Although the knoll was eroded, no artifacts or features were observed on the surface.

With the exception of Shovel Test 17, shovel tests $(1-8,16,18-19)$ on the eroded western and 


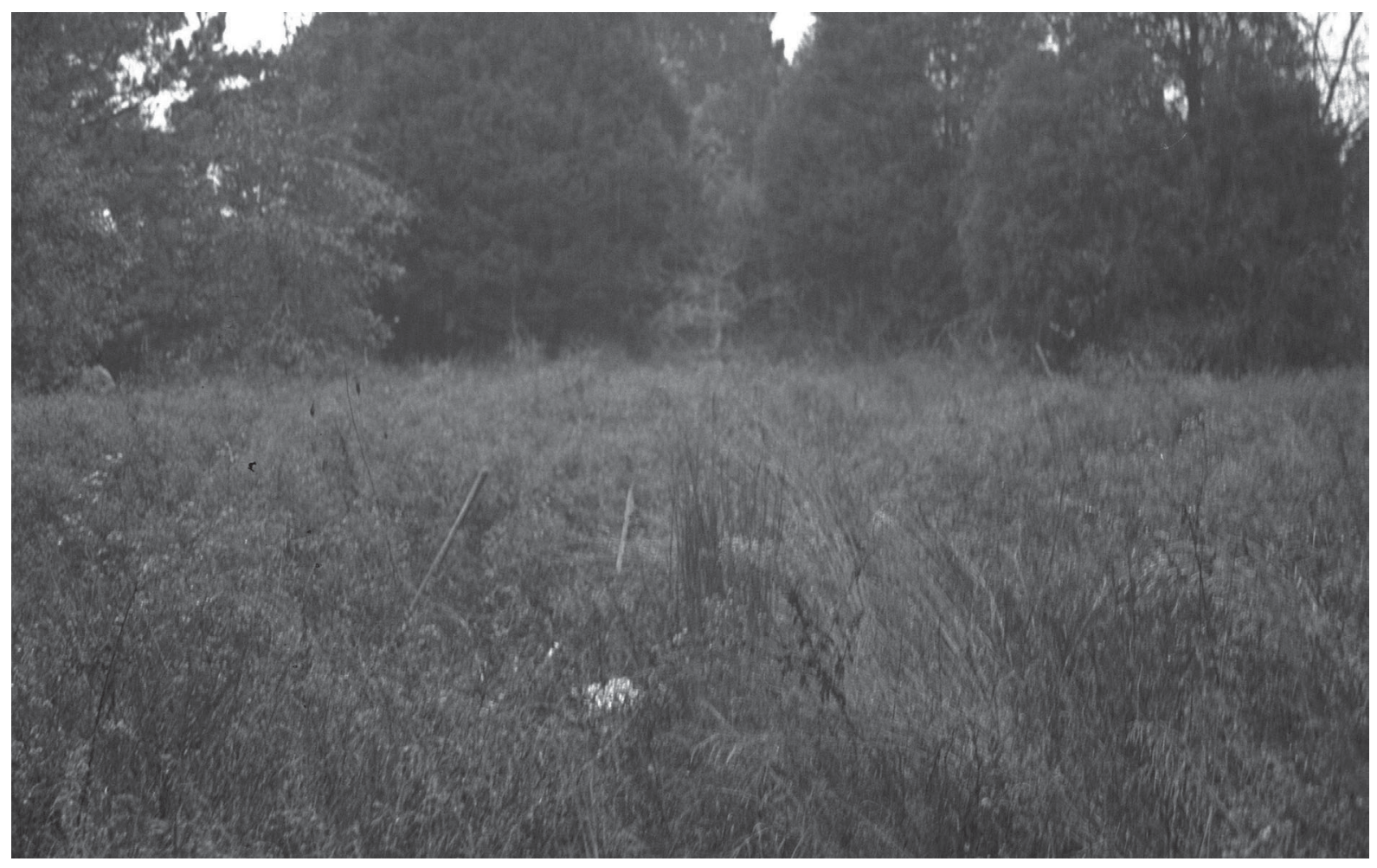

Figure 4-1. 41BP93 lies on a ridge and sideslope; facing north.

FIGURE 4-2. REDACTED

Figure 4-2. Site map, 41BP93. 


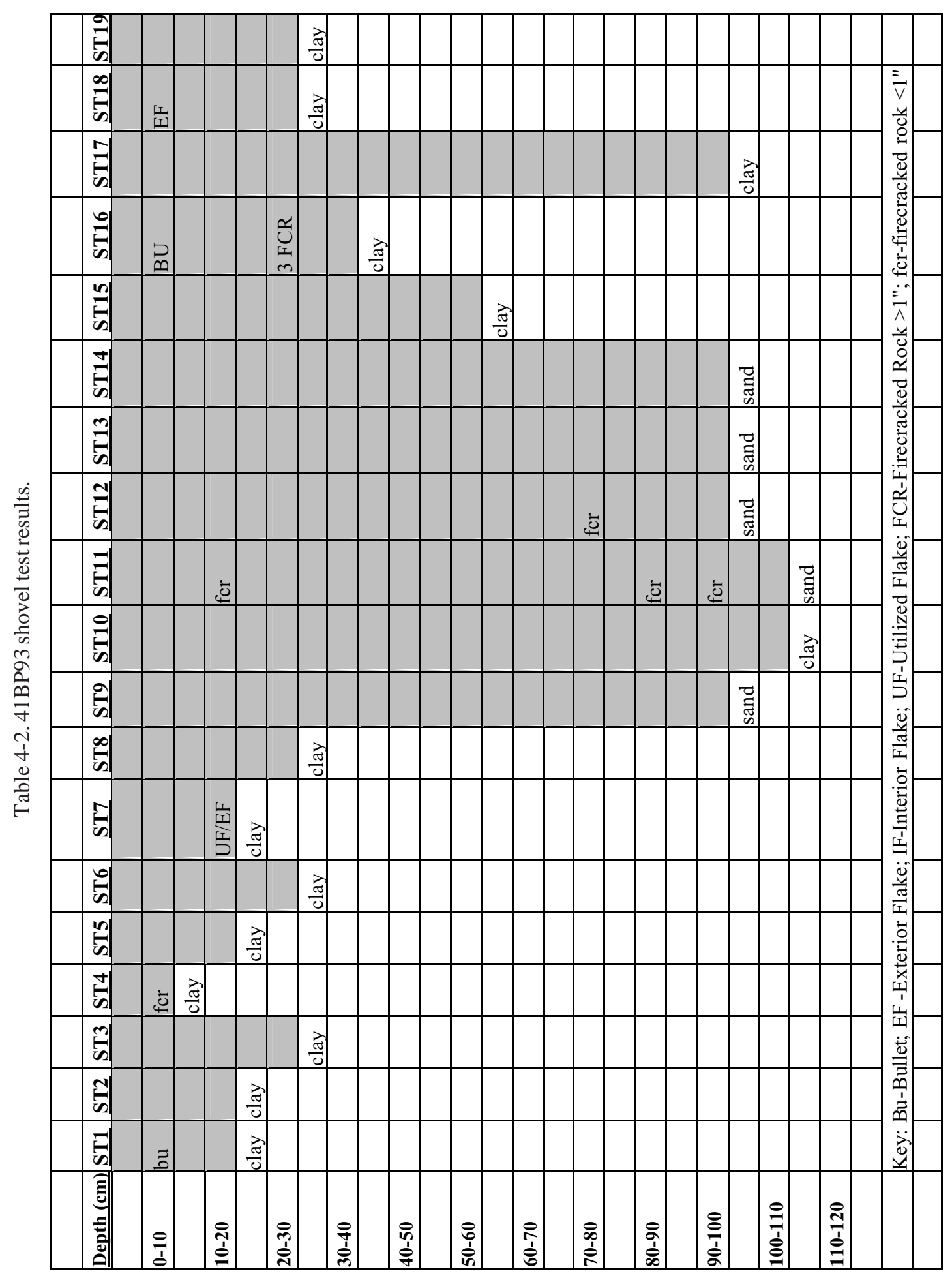




\section{Conclusions/Recommendations}

In its current condition, it appears that this site was probably used as a short-term open campsite where limited lithic reduction activities occurred. Cultural materials recovered from the shovel tests were either from shallow, eroded, and mixed contexts, or within secondary, colluvial deposits. Therefore we assess the research value of this site as a single entity to be minimal, and its value increases only slightly when considered in context with other small open campsites in the region. We recommend no further testing.

\section{BP94}

\section{Description}

Site 41BP94 (Figures 4-3 and 4-4) is a prehistoric open campsite approximately $7,723 \mathrm{~m}^{2}$ in size, and ranging in elevation from 430 to 435 feet. The site is situated on a terrace that overlooks the floodplain of McLaughlin Creek to the south. The area is generally wooded with moderately dense stands of oak and juniper, and to the east is an old field, open area that consists mainly of tall grasses supported by Axtell fine sandy loam (AfC2). The site is bisected by an intermittent drainage of McLaughlin Creek. West of this drainage is a raised roadbed and erosional gully, intersected by a fenceline that runs northwest-southeast. Surface visibility was approximately 10 percent.

\section{Levels of Work and Results}

In 1979, Skelton and Freeman found two pieces of modified silicious wood, and also noted two concentrations of firecracked quartzite and limestone exposed in the erosional gully near the east-

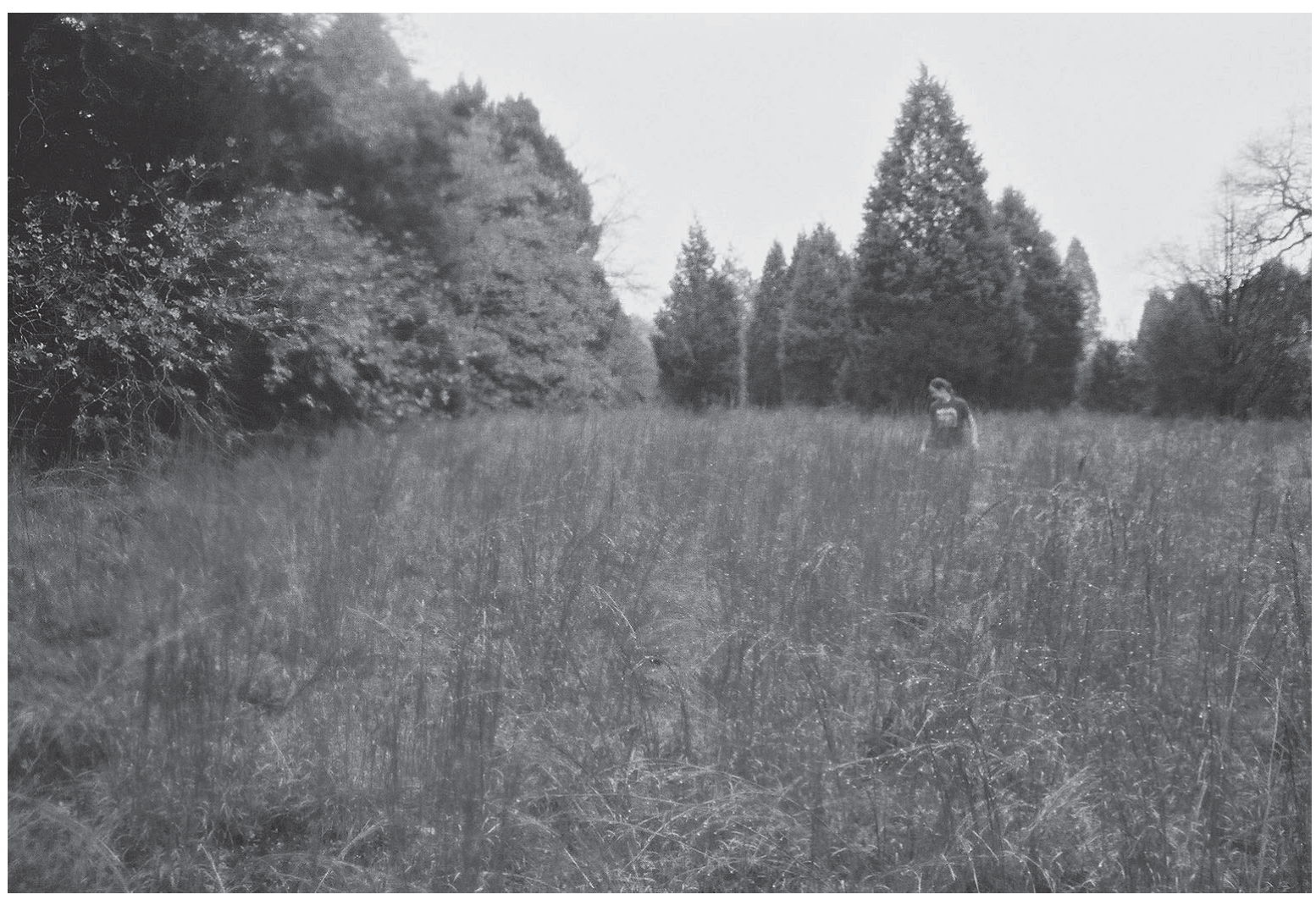

Figure 4-3. 41BP94 lies on an old-field terrace at the confluence of an intermittent tributary and Big Sandy Creek; facing north. 


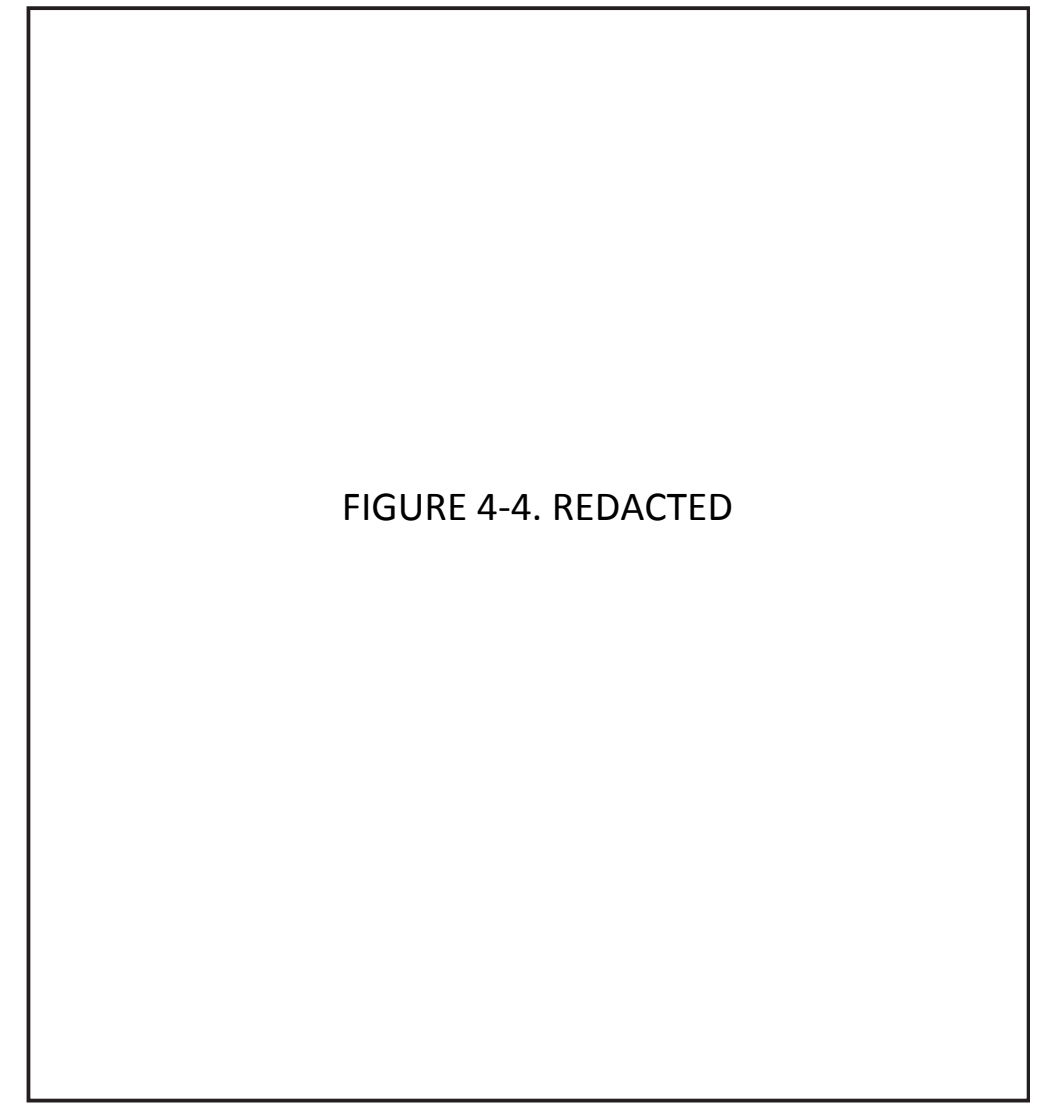

Figure 4-4. Site map, 41BP94.

ern portion of the site. Upon revisit in 1997, Robinson et al. found two flakes in a single probe and nine pieces of burned rock, three flakes, and an Ensor point in shovel tests.

In 2002, CAS-SWT excavated 18 shovel tests and recovered 51 small $(<1 ")$ pieces of firecracked rock, 17 larger (>1") pieces of firecracked rock, 26 interior flakes, 7 utilized flakes, 2 pieces of lithic shatter, 1 hammerstone, and a piece of milk glass (Table 4-3). One crude biface was observed on the surface, and a firecracked rock hearth feature was observed in the eastern cutbank of the drainage.

\section{Conclusions/Recommendations}

In its current condition, this site appears to have been used extensively as a prehistoric campsite where limited lithic reduction activities occurred. An Ensor point recovered from a shovel test during an earlier testing project suggests a Late Archaic occupation. In addition to hearth features partially buried in the cutbank, recent testing by CAS-SWT provided evidence of possibly intact features as deep as $100 \mathrm{~cm}$ below the surface. Such deposits may yield information regarding the paleoenvironment, site formation processes, and can infer past subsistence and mobility patterns when applied to theoretical models.

Although a single piece of glass was found between 50-60 $\mathrm{cm}$ in Shovel Test 15, the preponderance of data suggests that the research value of this site is considered high. We rcommend two 1x1-m units over the hearth features eroding from the cutbank; two backhoe trenches in the areas of Shovel Tests 1-4 on the west side of the drainage, and three backhoe trenches on the east side of the drainage around Shovel Tests 8, 12, and 15 . Should potentially intact features be encountered during trenching operations, additional $1 \mathrm{x} 1-\mathrm{m}$ units should be excavated to further evaluate the overall significance of the site.

\section{BP100}

\section{Description}

41BP100 (Figures 4-5 and 4-6) is a prehistoric open campsite covering approximately $11,050 \mathrm{~m}^{2}$ adjacent to McLaughlin Creek (Figure 4-7). Ranging in elevation from 420 to 430 feet, the site is located on an open footslope and wooded area 


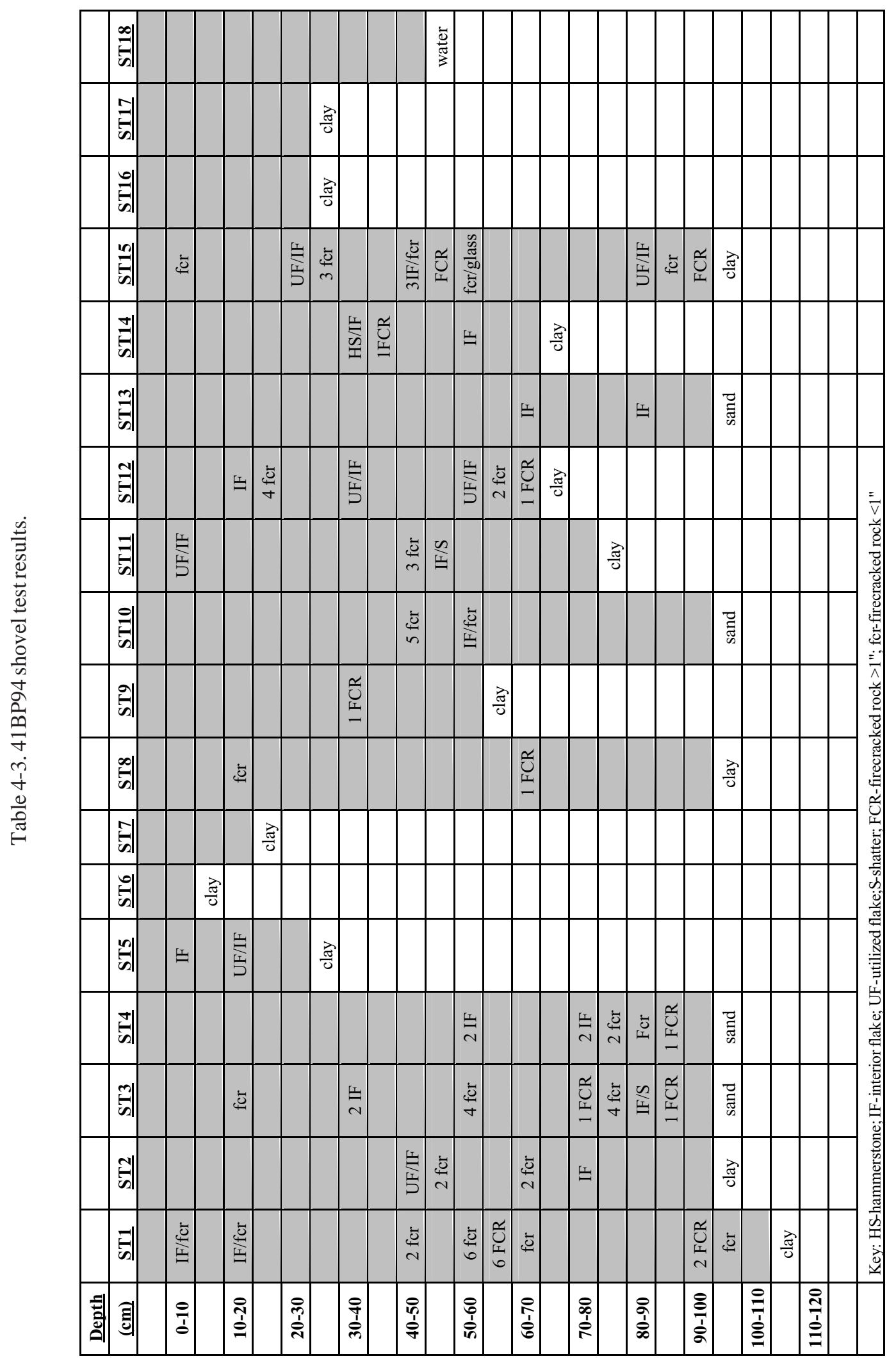


along the creek. Patilo Complex loose fine sand $(\mathrm{PaE})$ and Axtell fine sandy loam (AfC2) support tall grasses in the open field and moderately dense stands of pine and cedar in the wooded area. Disturbances such as military tank tracks and a trench have slightly impacted this site (Figure 4-8). The trench runs along the woodline through the sourthern portion of the site. Surface visibility other than in the trench was approximately 50 percent.

Levels of Work and Results

When Skelton and Freeman first recorded the site in 1979, they did not collect anything, but noted two hearth features eroding out of the cutbank of the creek. The features were approximately $90 \mathrm{~cm}$ and $1.75 \mathrm{~m}$ below the edge of the cutbank. These feaFIGURE 4-5. REDACTED tures were also noted by Robinson et al. in 1997,

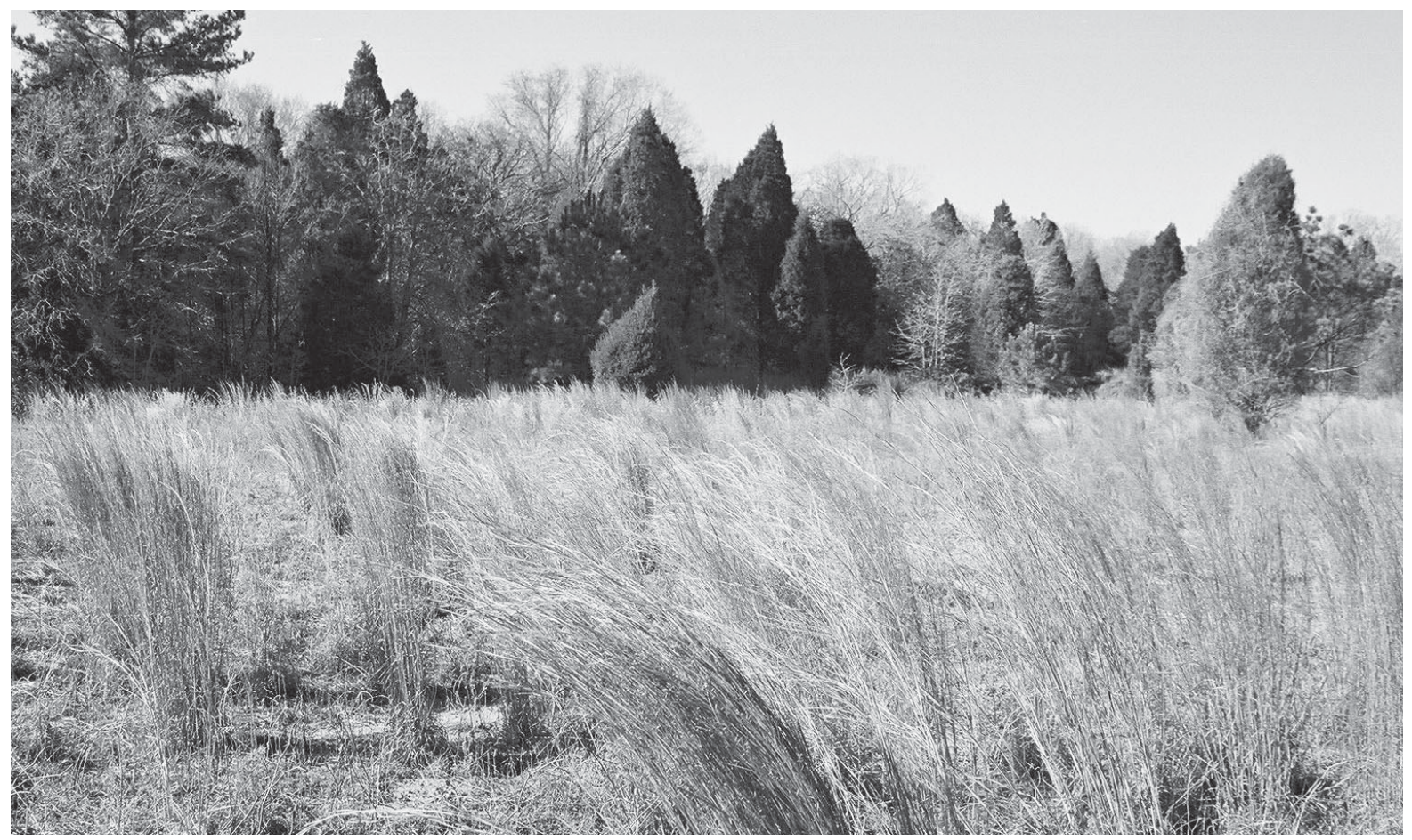

Figure 4-6. 41BP100 spans an old-field footslope adjacent to McLaughlin Creek; facing southwest. 


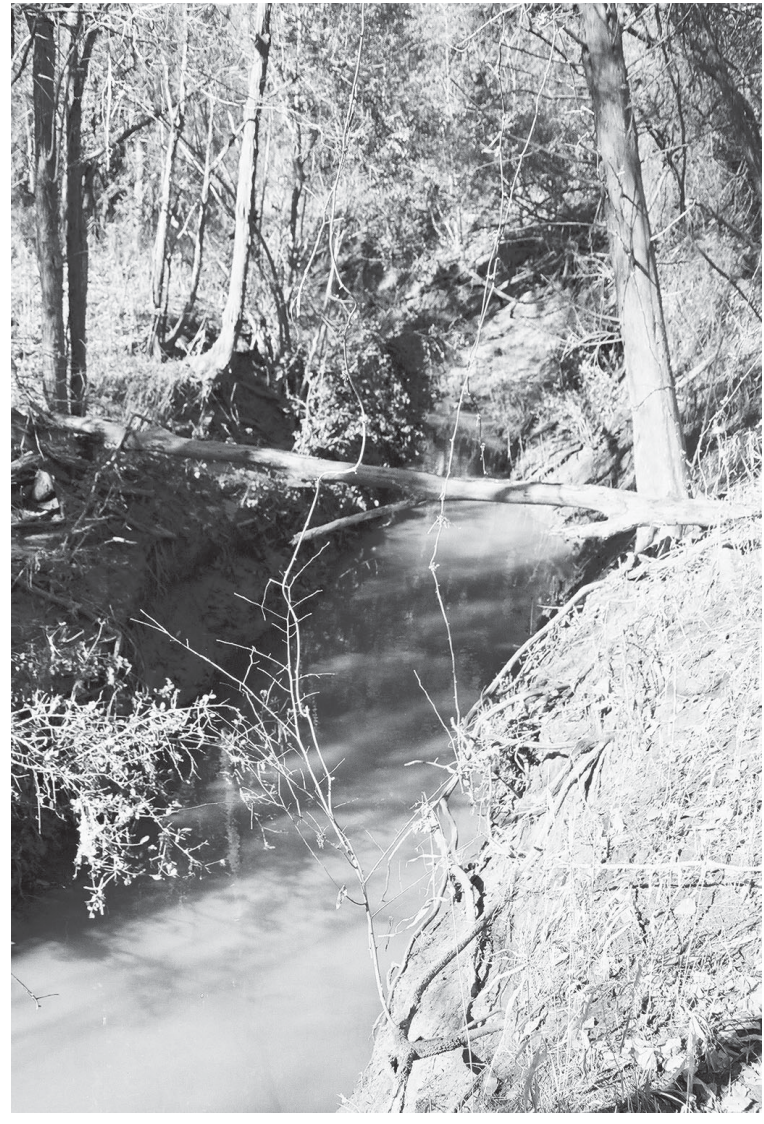

Figure 4-7. McLaughlin Creek at the southern edge of 41BP100; facing west.

along with some burned rock recovered from three of their six shovel tests.

In 2003, CAS-SWT personnel excavated 18 shovel tests (Figure 4-9) and collected (see Table 4-4) 16 large (>1") pieces of firecracked rock, 6 small ( $<1 ")$ pieces of firecracked rock, 23 interior flakes, 3 exterior flakes, 1 utilized flake, 1 biface that is a probable arrow point tip (Figure 4-11), and 1 pottery sherd from the surface (Figure 4-12). A very ephemeral scatter of lithic debitage was observed across the site, except for a slightly heavier scatter along the sides and bottom of the trench. CAS also observed a scattered firecracked rock hearth feature in the bottom of the approximately 50-cm-deep trench just north of McLaughlin Creek (Figures 4-6, 8 and 10).

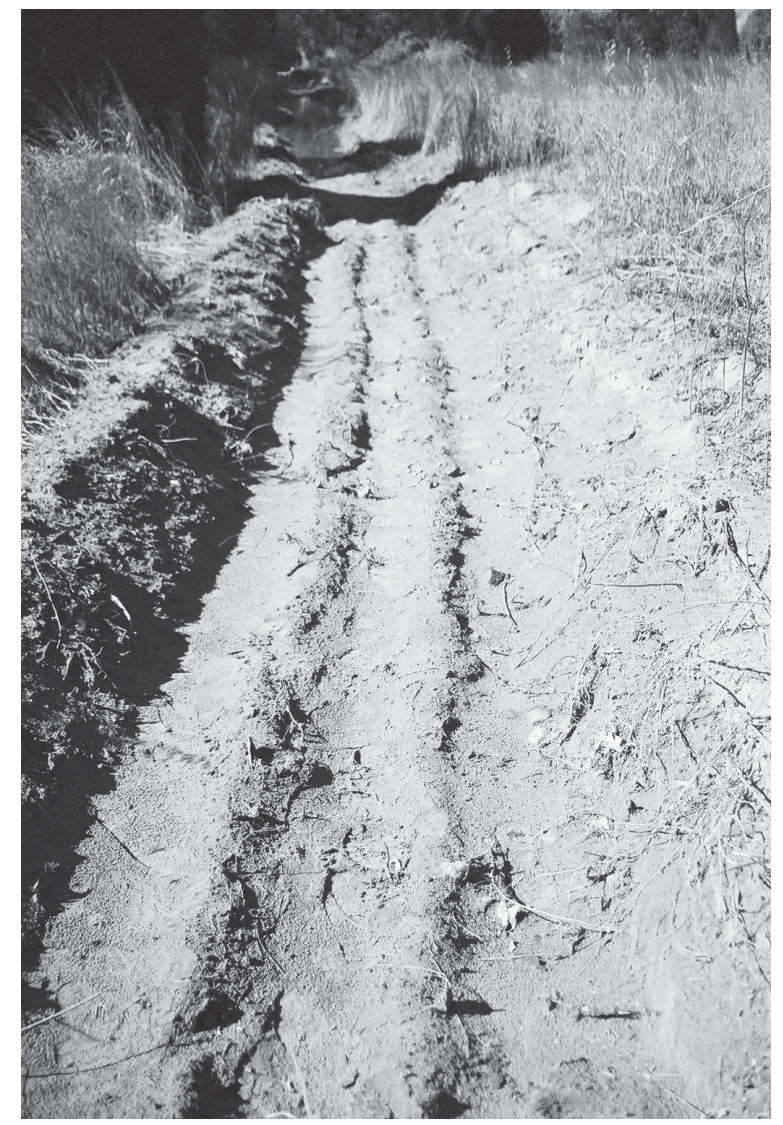

Figure 4-8. Trench cut through the lower portion of 41BP100; facing southeast.

\section{Conclusions/Recommendations}

In its current condition this site appears to have been used as a prehistoric campsite where lithic reduction activities occurred. An examination of the results of shovel testing (Table 4-4) suggests two probable isolable components; an upper component between $0-30 \mathrm{~cm}$, and a lower component between $70-110 \mathrm{~cm}$. The recovery of a pottery sherd and probable arrow point tip indicates a Late Prehistoric component in the upper $30 \mathrm{~cm}$.

Although military usage has moderately disturbed the area, it still subjectively appears to be about 70 percent intact. The amount of artifacts and depths at which they were encountered indicate possibly intact cultural features buried deep below the surface. Such features have the potential 


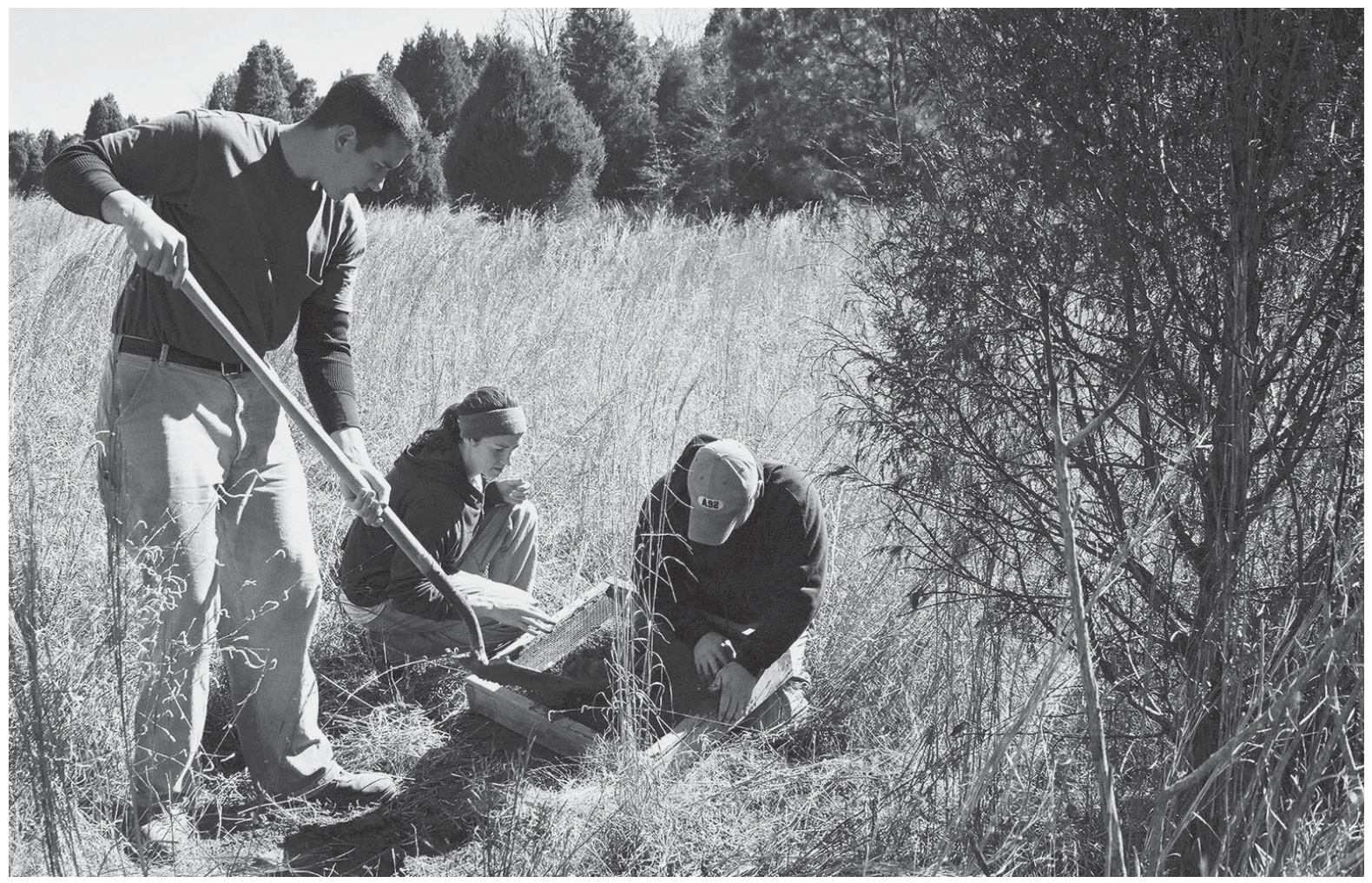

Figure 4-9. Shovel testing at 41BP100; facing west.

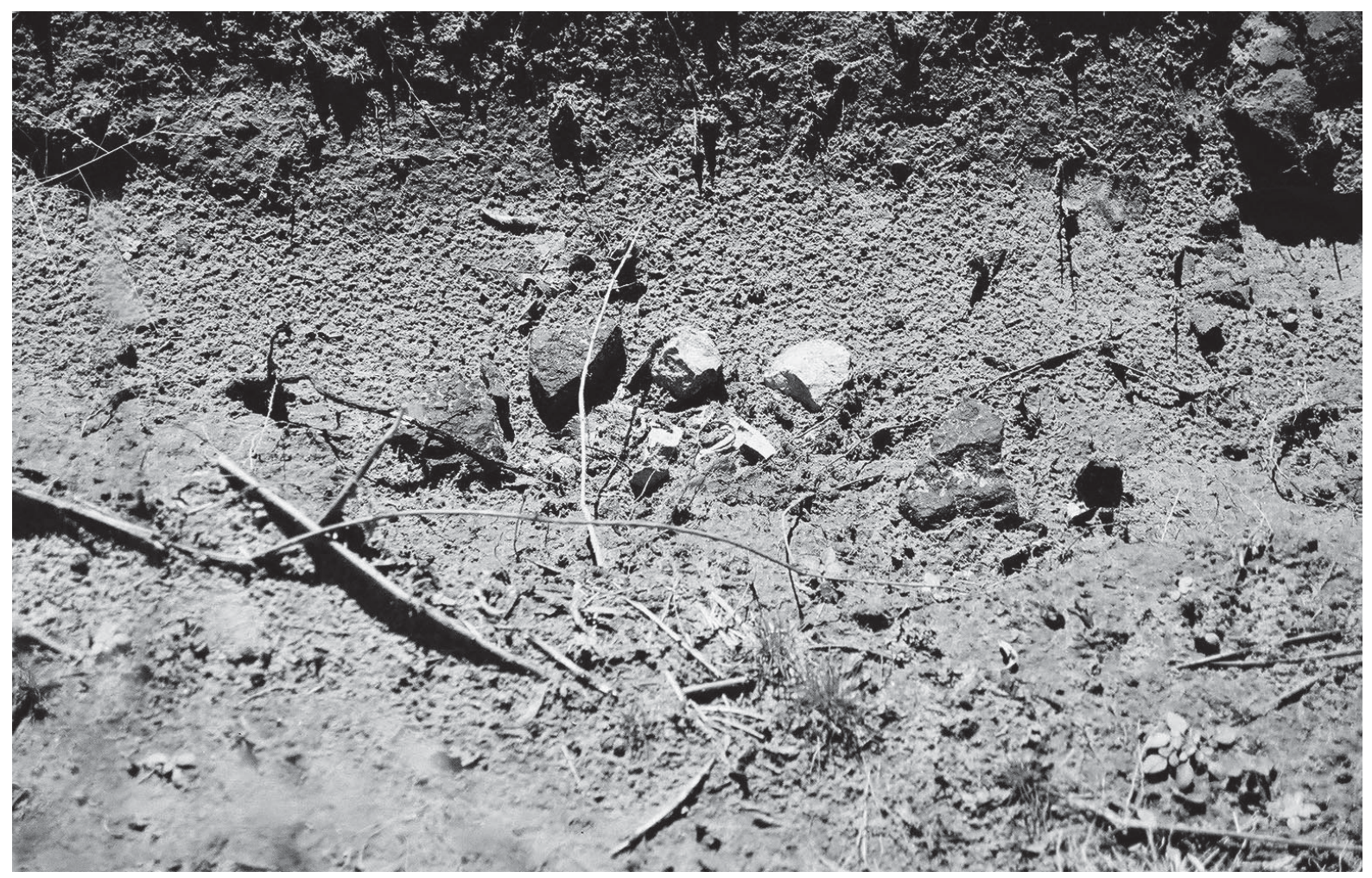

Figure 4-10. Scattered firecracked rock hearth feature lying on the bottom of a trench at 41BP100; facing west. 


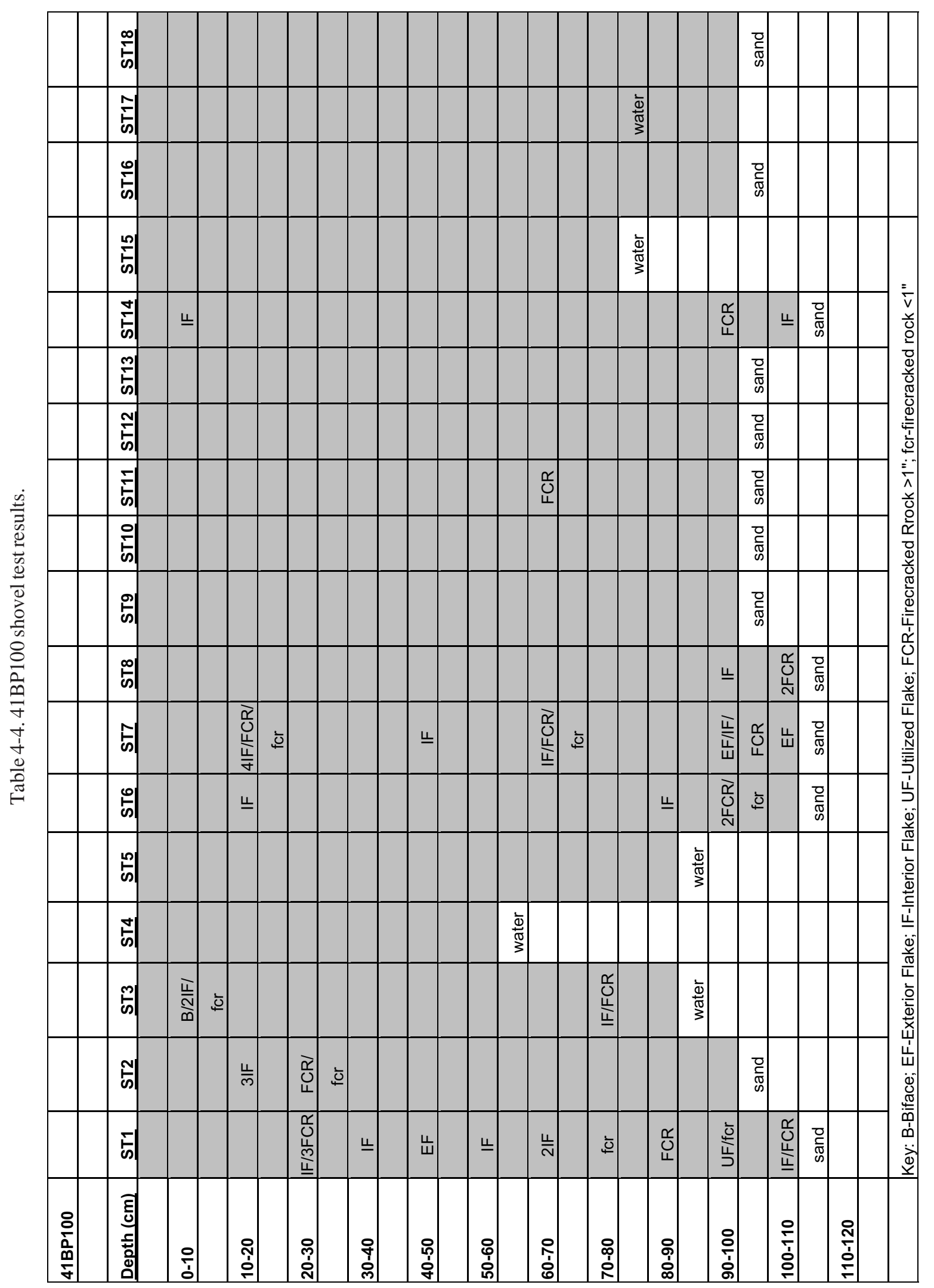




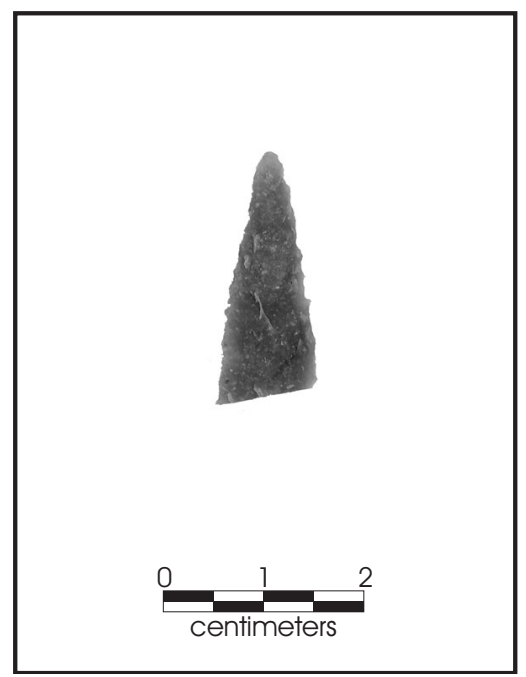

Figure 4-11. Distal tip of an arrow point collected from Shovel Test 3, 0-10 $\mathrm{cm}$ below the surface.

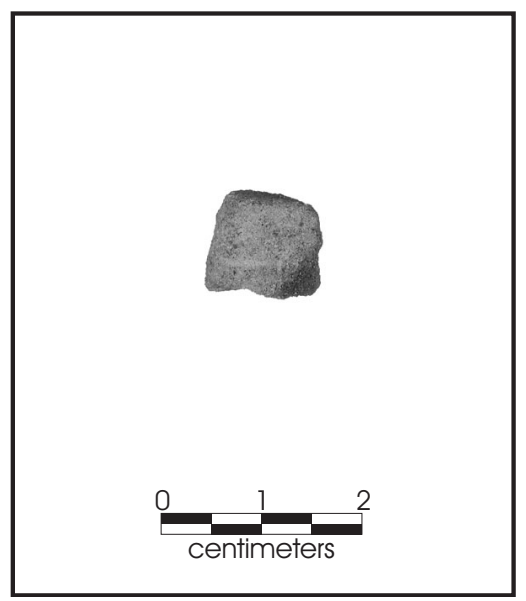

Figure 4-12. Sandy paste brownware sherd collected from the edge of the trench at 41BP100.

to yield significant information about the paleoenvironment and site formation processes, and can infer past subsistence and mobility patterns when applied to theoretical models. Therefore, the research value of this site is considered high, and we recommend: one $1 \times 1-m$ unit adjacent to the scattered FCR found in the bottom of the trench; one backhoe trench in the wooded area near the creekbank, and three backhoe trenches on the footslope around Shovel Tests 1-3, 6-8, and 14. Should potentially intact features be encountered during trenching operations, additional 1x1-m units should be excavated to further evaluate the overall significance of the site.

\section{BP105}

\section{Description}

41BP105 (Figures 4-13 and 4-14) is a prehistoric open campsite with scattered historic trash (see Section II for a discussion of the historic component). The prehistoric component covers approximately $3,845 \mathrm{~m}^{2}$, and ranges in elevation from 410 to 420 feet. The area is located in an open field, on a lower terrace just west of the confluence of a spring-fed stream and Big Sandy Creek. The open field was the location of a historic vineyard, with a possible irrigation channel along its northwestern portion. Sayers fine sandy loam (Sa) now supports small isolated oak and mesquite trees in the field, as well as thicker riverine trees and brush along the edges of both creeks. Remnants of grapevines are also present in the open field amidst tall grasses. Surface visibility was approximately 20 percent.

\section{Levels of Work and Results}

Initial investigations at the site were conducted by Skelton and Freeman in 1979. No cultural material was collected, however, they did note a rock hearth exposed in a channel cutbank. The cluster of rock was 1 meter in length and consisted of a single layer of firecracked chert, quartzite, and limestone. The feature was situated 1 meter above the water level, and $50 \mathrm{~cm}$ below the surface of the terrace.

In 2002, CAS-SWT personnel excavated 19 shovel tests. Fifteen of the nineteen shovel tests 


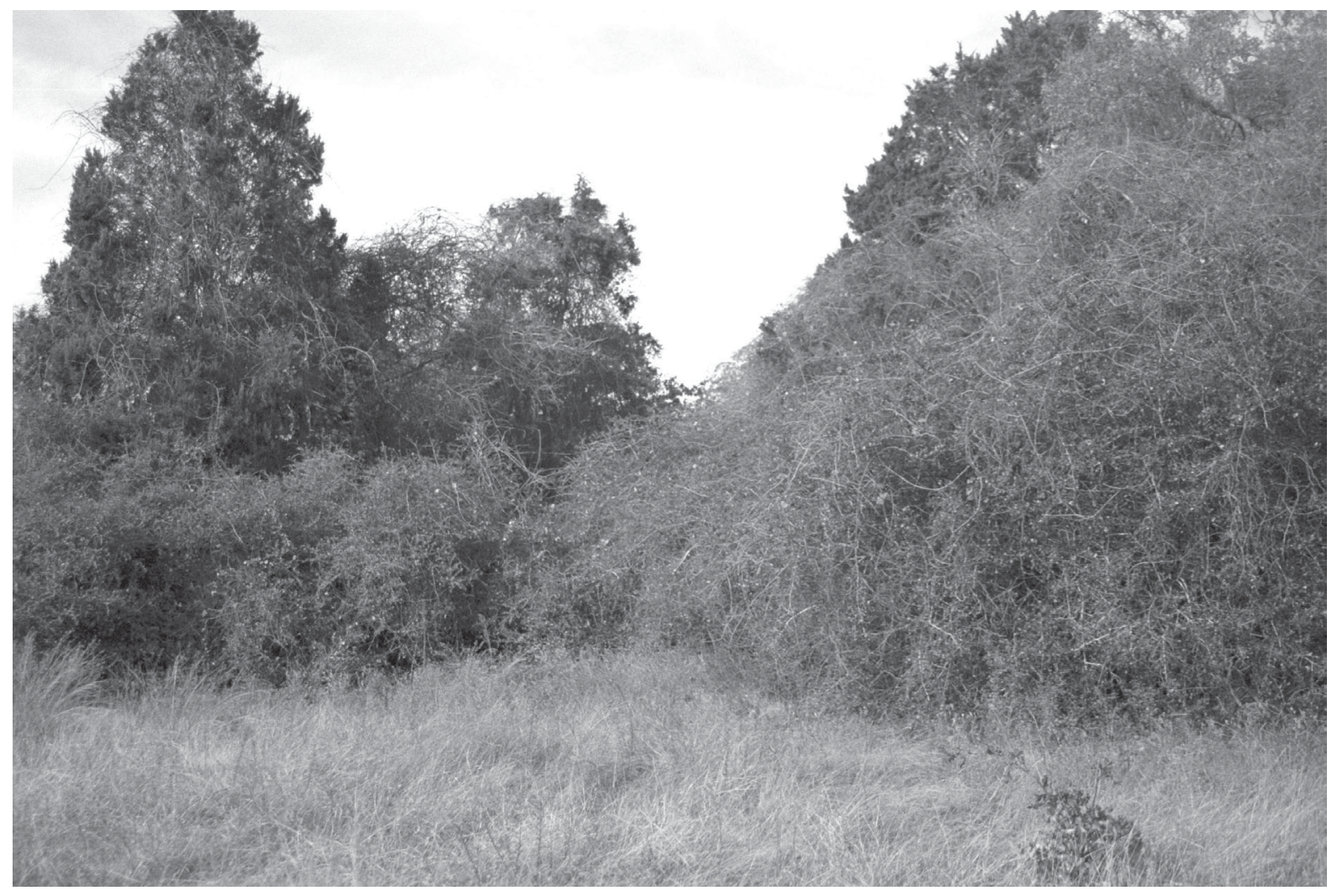

Figure 4-13. Shovel testing at 41BP105, a lower terrace site along Big Sandy Creek; facing west.

were positive, with deposits as deep as $100 \mathrm{~cm}$ below the surface. Grey clay and the water table at 40 cm were encountered on the western portion of the site. An historic pottery sherd was uncovered in shovel test 14 from $60-70 \mathrm{~cm}$ below the surface, and a bullet casing and piece of glass were found in the upper $30 \mathrm{~cm}$ of shovel tests 2 and 17, respectively.

Artifacts collected from 2002 shovel testing included 14 small $(<1 ")$ pieces of firecracked rock, 6 larger (>1") pieces of firecracked rock, 4 utilized flakes, 30 interior flakes, 1 piece of lithic

FIGURE 4-14. REDACTED

Figure4-14. Site map,41BP105. 


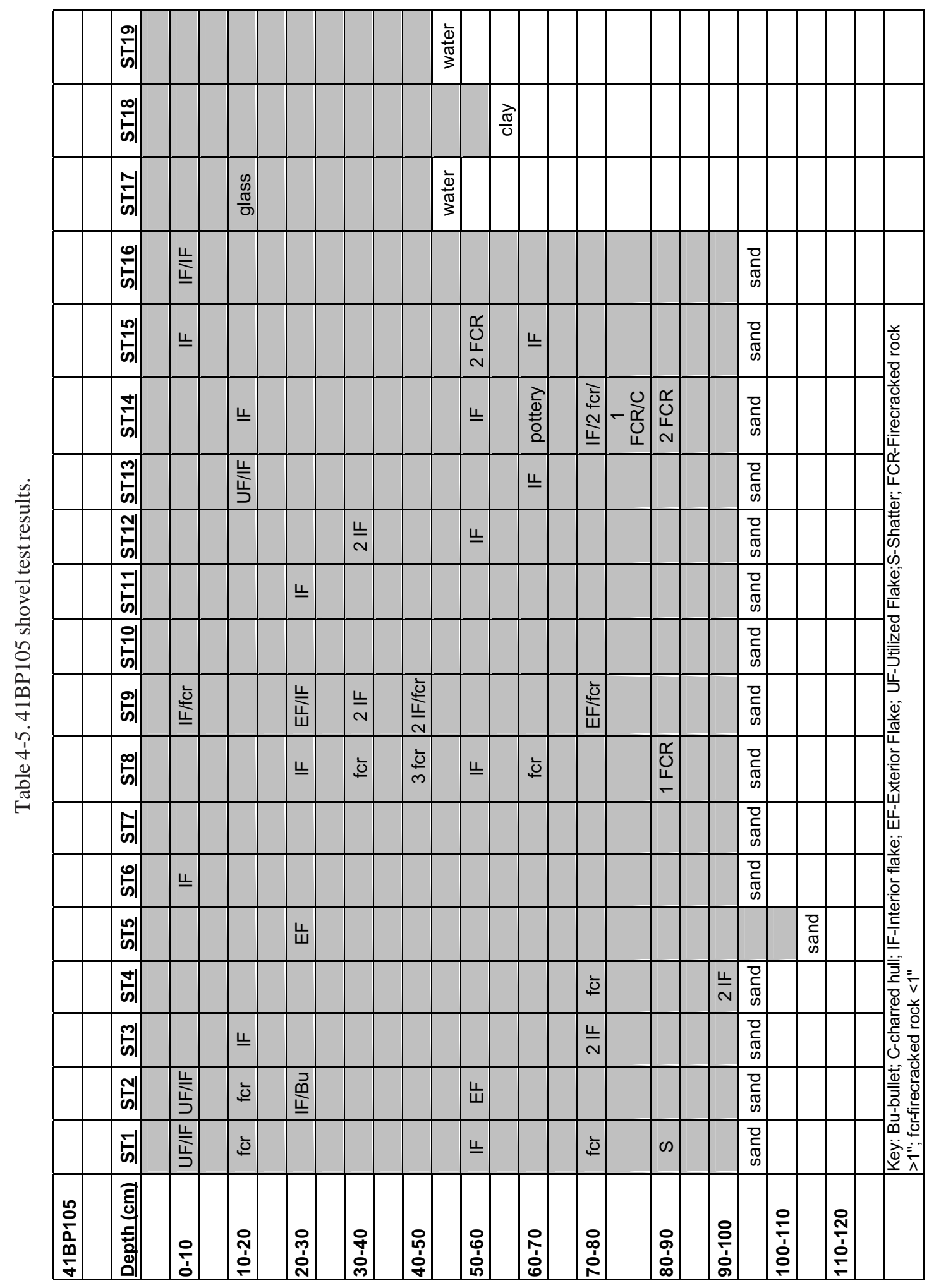


shatter, 1 bullet casing, 4 exterior flakes, the piece of clear glass, 1 charred hull and the piece of historic pottery (Table 4-5). No artifacts were observed on the surface.

\section{Conclusions/Recommendations}

In its current condition, this site appears to have been used as a small prehistoric open campsite where lithic reduction activities occurred. Although the upper $30 \mathrm{~cm}$ is likely disturbed due to cultivation, a potentially intact layer from $70-90 \mathrm{~cm}$ contains flakes, larger firecracked rock, and a charred hull. The presence of deeply buried firecracked rocks found during shovel testing, coupled with Skelton and Freeman's (1979) observation of an eroding hearth, indicate that there may be intact cultural features buried deep below the surface. Intact cultural features and preserved macrobotanical remains have the potential to pro- vide significant information about the paleoenvironment, site formation processes, and can infer past subsistence and mobility patterns when applied to theoretical models.

Therefore, the research value of this site is considered high. In order to further evaluate its integrity, we recommend four backhoe trenches be excavated around Shovel Tests 3, 4, 8-9, and 14. Should potentially intact features be encountered during trenching operations, $1 \times 1$-m units should be excavated to further evaluate the overall significance of the site.

\section{BP111}

\section{Description}

41BP111 (Figure 4-15 and 4-16) is a prehistoric open campsite with firecracked rock and an

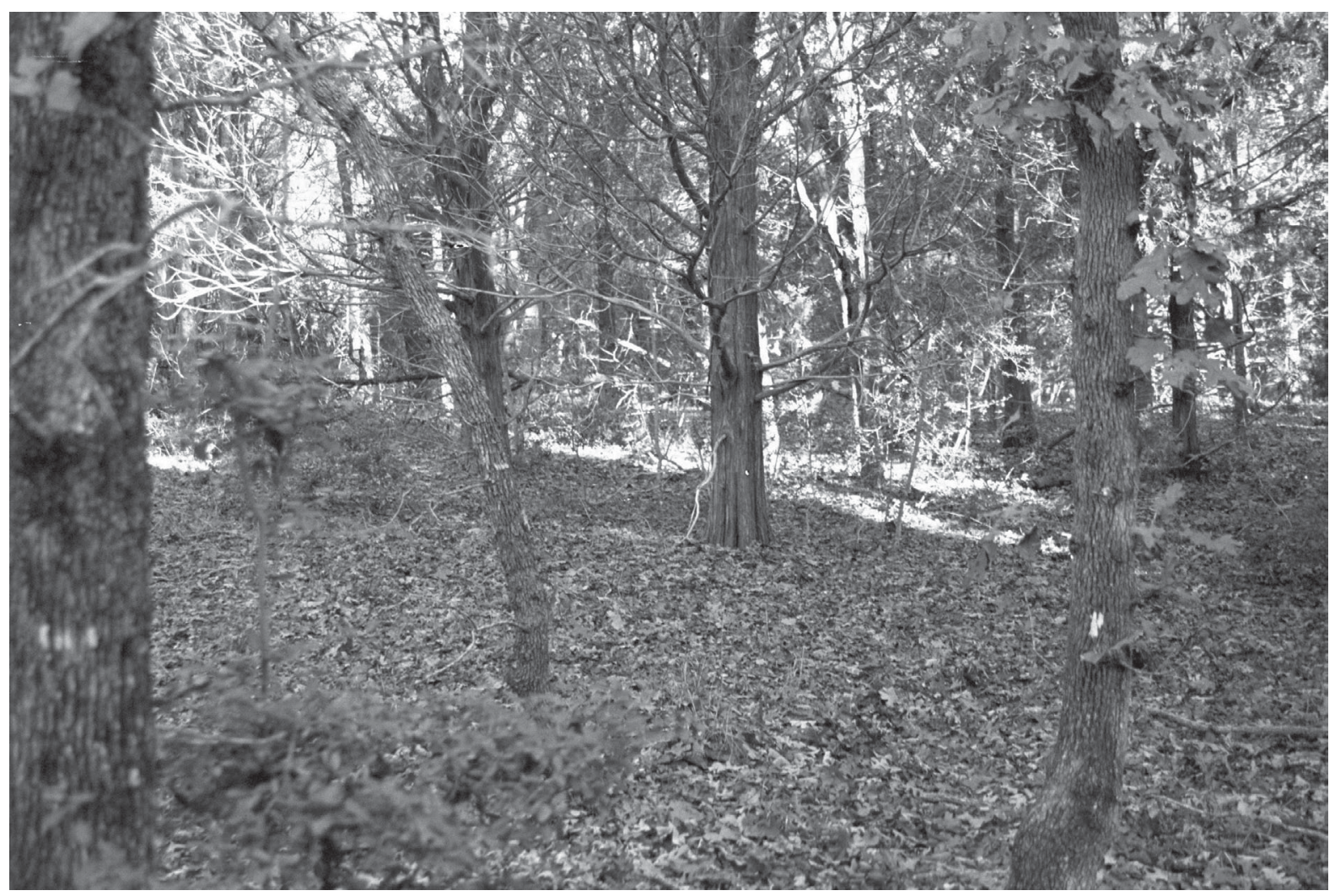

Figure 4-15. 41BP111 sets on a wooded ridge and sideslope; facing northwest. 


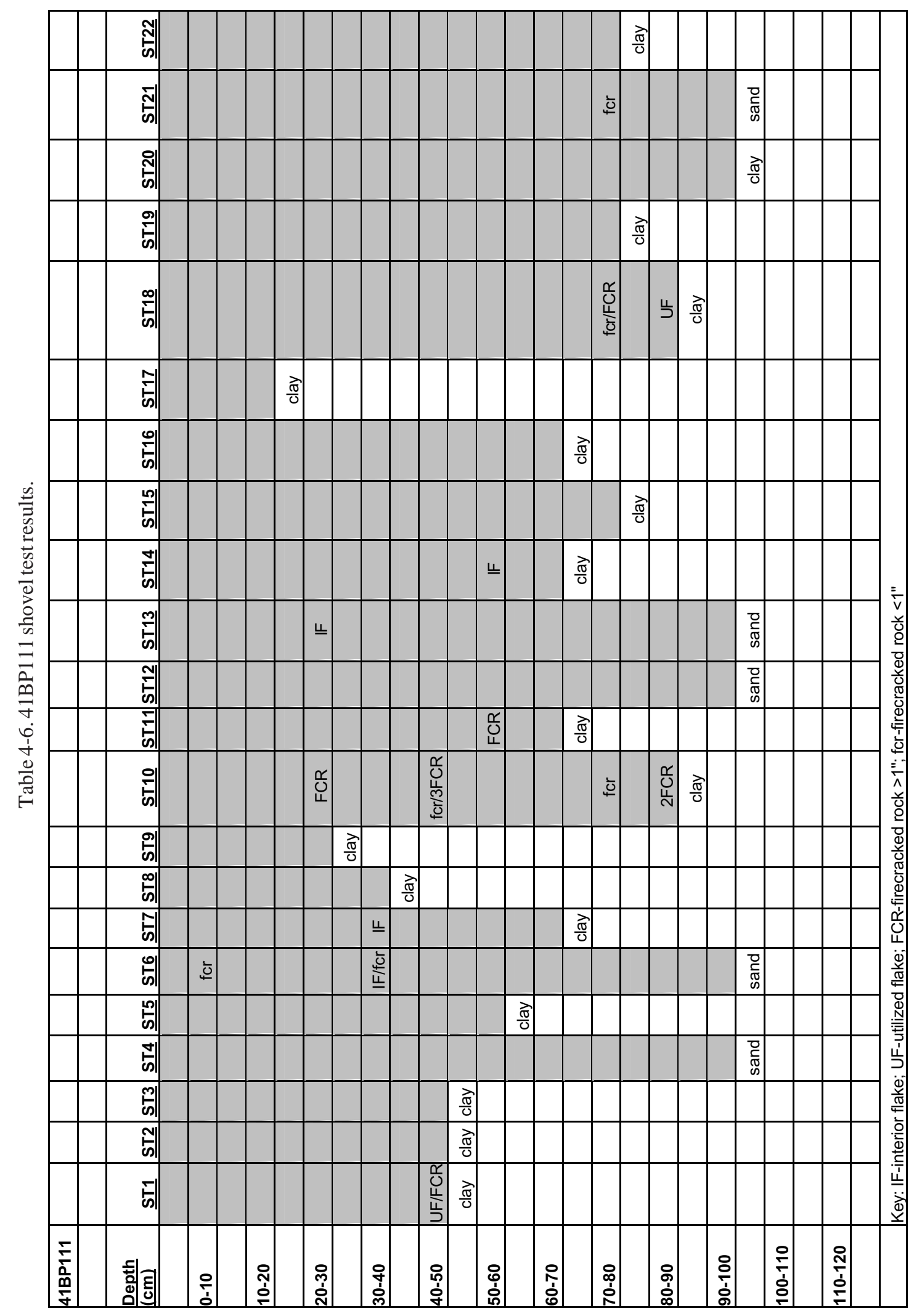




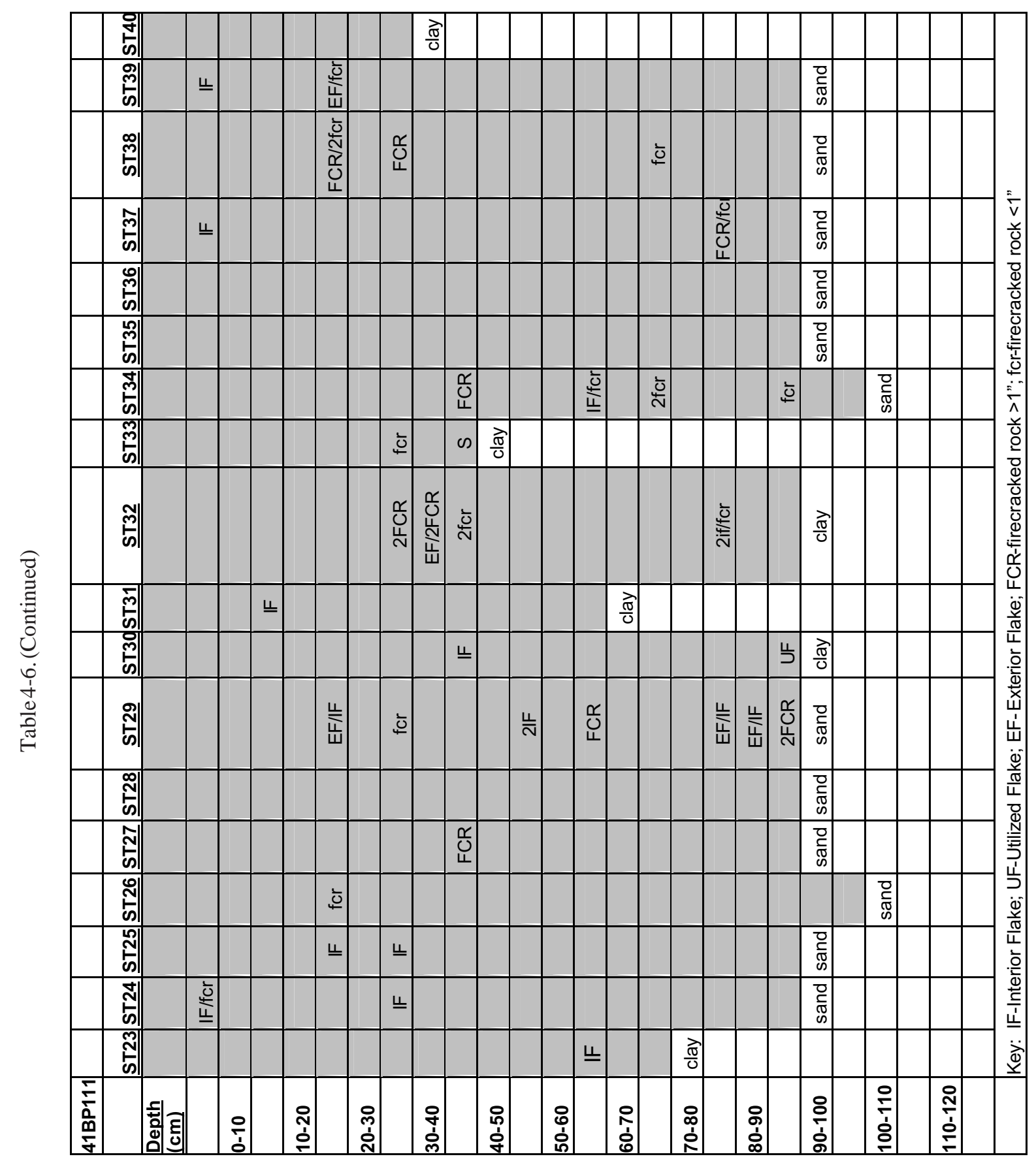




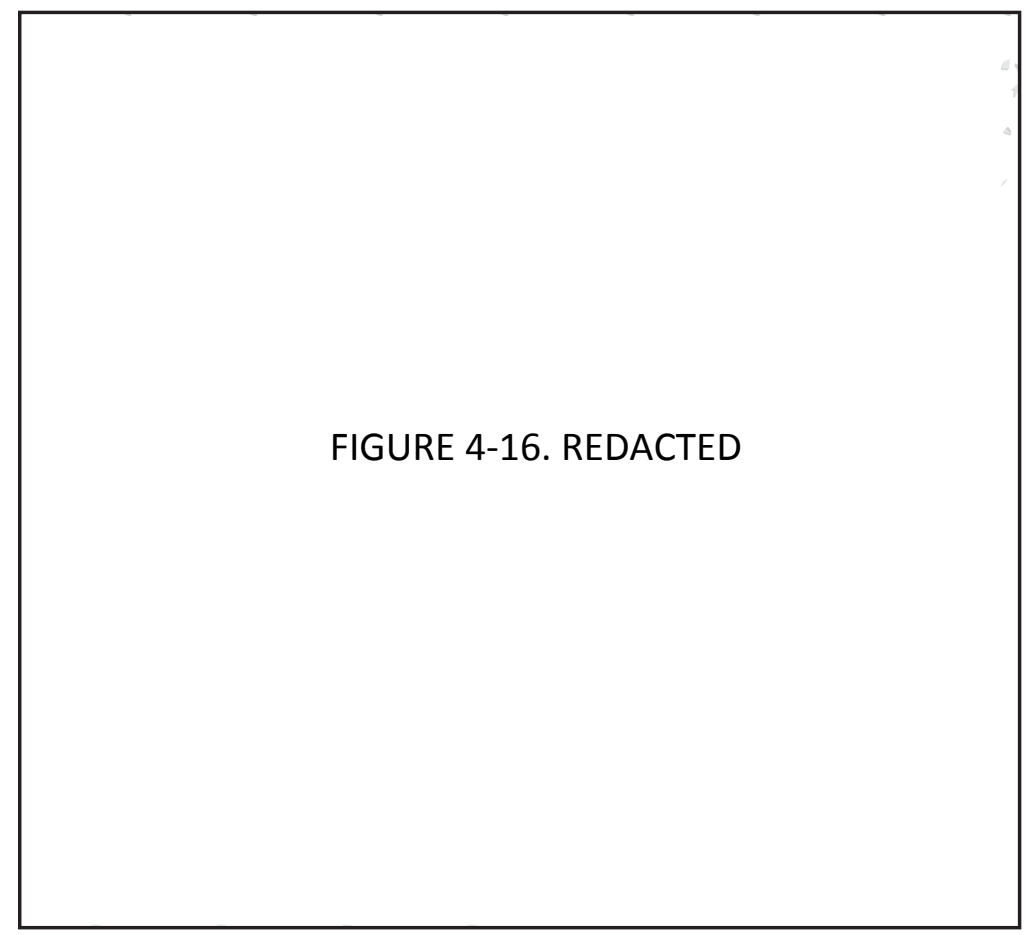

Figure4-16. Site map,41BP111.

associated lithic scatter. The site covers approximately $23,049 \mathrm{~m}^{2}$, and ranges in elevation from 450 to 475 feet. It straddles a heavily wooded ridge and sideslope, with Patilo complex soils (PaE) supporting dense stands of post oak, black walnut, hickory, and juniper. The ridge slopes in a southeasterly direction toward an intermittent, upper tributary McLaughlin Creek. Surface visibility was <5 percent.

\section{Levels of Work and Results}

This site was originally recorded by Skelton and Freeman in 1979. At that time they observed remnants of two firecracked rock hearths in a cutbank profile 25 and $35 \mathrm{~cm}$ below the surface, respectively, as well as five flakes in the upper 25 $\mathrm{cm}$. Both features appeared to be remnants of prehistoric hearths constructed of chert, quartzite, hematite, and silicious wood. They subsequently excavated a single $1 \times 1-\mathrm{m}$ test unit, recovering 1 core fragment, 116 pieces of firecracked rock, 6 secondary flakes, 26 tertiary flakes, and 6 chips.

In 2002 and 2003, no artifacts were observed on the surface, but CAS personnel excavated 40 shovel tests and collected 21 large $(>1 ")$ pieces of firecracked rock, 22 smaller ( $<1 ")$ pieces of firecracked rock, 21 interior unmodified flakes, 4 exterior unmodified flakes, 3 utilized flakes 1 retouched flake and 1 piece of lithic shatter (Table 4-6). Shovel Tests 1-23 were placed on the upper portion of the ridge (Area A), while Shovel Tests 24-40 were placed on the sideslope (Area B) along an intermittent drainage (Figure 4-16).

Although Skelton and Freeman's test unit could not be located, from their description it appears that (1979:34-38) it was located adjacent to the intermittent drainage along the eastern portion of our designated Area B (see Figure 4-16). Our inspection of the cutbank in that area revealed no evidence of buried hearth remnants or isolated artifacts. However, we did encounter deep sands, deeply buried artifacts, and 10 larger (>1") pieces of buried firecracked rock in that area (see Table 4-6).

Skelton and Freeman (1979:36) terminated excavations $100 \mathrm{~cm}$ below the surface, and noted that sterile soils were encountered between 85-100 $\mathrm{cm}$. Less than 13 percent of the chipped stone, and less than 20 percent of the firecracked rock recovered by Skelton and Freeman came from below 50 $\mathrm{cm}$. However, of the 14 shovel tests in Area B that were dug to $100 \mathrm{~cm}$ by CAS, greater than 45 
percent of the chipped stone, and greater than 33 percent of the firecracked rock came from below $50 \mathrm{~cm}$.

\section{Conclusions/Recommendations}

In its current condition, this site appears to have been used as a prehistoric campsite where lithic reduction activities occurred. The presence of larger pieces of firecracked rock in ten of our shovel tests, coupled with Skelton and Freeman's previously noted eroding hearth features in Area B indicate that this site may possibly contain intact cultural deposits buried deep below the surface. While we generally encountered deeper sands and cultural materials in Area B than in Area A (see Table 4-6), the recovery of larger pieces of buried firecracked rock suggest the possible presence of intact features in Area A also. Such deposits have the potential to yield significant information about the paleoenvironment, site formation processes, and can infer past subsistence and mobility patterns when applied to theoretical models. Therefore, the research value of this site as a single entity is considered high. In order to further evaluate the potential of this site, we recommend five backhoe trenches be excavated around Shovel Tests 10, 29, 32,34, and 37-38. Should potentially intact features be encountered during trenching operations, 1x1-m units should be excavated to further evaluate the overall significance of the site.

\section{$41 B P 113$}

\section{Description}

41BP113 (Figures 4-17 and 4-18) is a prehistoric open campsite with burned rock and an associated lithic scatter. The site covers approximately $20,500 \mathrm{~m}^{2}$, and ranges in elevation from 450

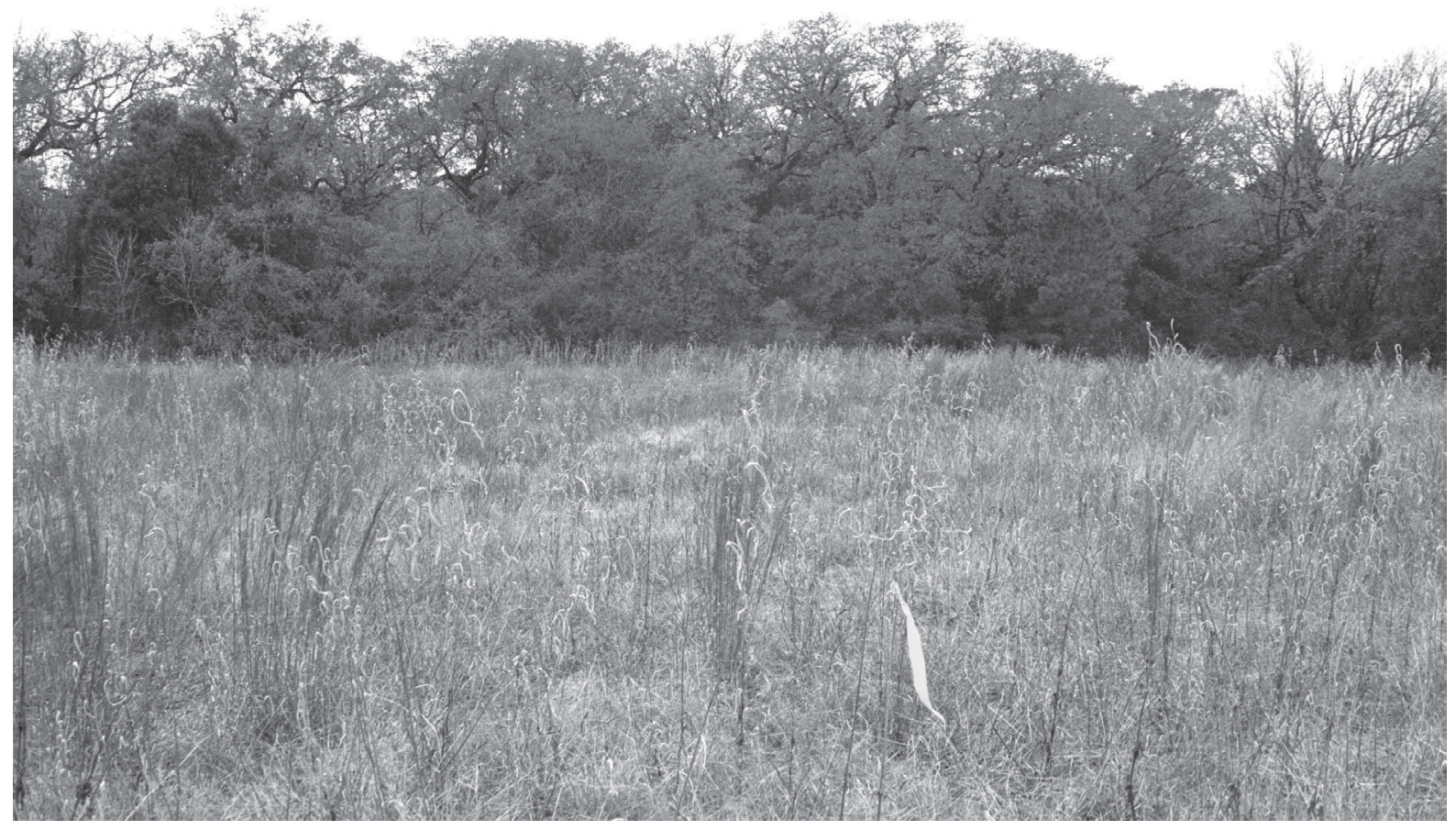

Figure 4-17. 41BP113 sets on an old-field sideslope above McLaughlin Creek; facing west. 
Table 4-7. 41BP113 shovel test results.

\begin{tabular}{|c|c|c|c|c|c|c|c|c|c|c|c|c|c|c|}
\hline \multicolumn{15}{|l|}{ 41BP113 } \\
\hline \multirow[t]{2}{*}{ Depth $(\mathrm{cm})$} & ST1 & ST2 & ST3 & ST4 & $\underline{\text { ST5 }}$ & $\underline{\text { ST6 }}$ & $\underline{\text { ST7 }}$ & $\underline{\text { ST8 }}$ & ST9 & $\underline{\text { ST10 }}$ & ST11 & $\underline{\text { ST12 }}$ & $\underline{\text { ST13 }}$ & $\underline{\text { ST14 }}$ \\
\hline & & & & MS & FCR & & & & & & & & & \\
\hline \multirow[t]{2}{*}{$0-10$} & & & & & & & & & & & & & $2 \mathrm{IF}$ & \\
\hline & & & & & & & & & & & & & & \\
\hline \multirow[t]{2}{*}{ 10-20 } & & & & & IF & & & & FCR & UF/fcr & & & & \\
\hline & & & & & & & & & & & & & & \\
\hline \multirow[t]{2}{*}{$20-30$} & & & & & & & fcr & & & & & & & \\
\hline & & & & & & & & & & & & & & \\
\hline \multicolumn{15}{|l|}{$30-40$} \\
\hline & & & & & & & & & & & & & & \\
\hline \multirow[t]{2}{*}{$40-50$} & IF & IF & & & & & fcr & $2 \mathrm{IF}$ & & & & & $2 \mathrm{IF}$ & $\mathrm{IF} / \mathrm{fcr}$ \\
\hline & & & & & & & & UF & & & & & & \\
\hline \multirow[t]{2}{*}{$50-60$} & $\mathrm{IF}$ & & & & $\mathrm{IF}$ & & & & & & & & IF & UF/IF \\
\hline & & & & & & & & & & & & & & $\mathrm{fcr}$ \\
\hline \multirow[t]{2}{*}{$60-70$} & & & & & & $2 \mathrm{IF}$ & & & & & & & $2 \mathrm{IF} / \mathrm{EF} / \mathrm{C}$ & \\
\hline & & & & & & & & & & & & & \begin{tabular}{|l|} 
FCR \\
\end{tabular} & \\
\hline \multirow[t]{2}{*}{$70-80$} & $\mathrm{fcr}$ & & & & IF/9 FCR & & fcr & & fcr & & & & $2 \mathrm{IF}$ & FCR \\
\hline & & & & & & & & & & clay & & & & \\
\hline \multirow[t]{2}{*}{$80-90$} & & & & & & fcr/FCR & & & $3 \mathrm{IF} / \mathrm{UF}$ & & & & $\mathrm{fcr}$ & $\mathrm{FCR}$ \\
\hline & & & & & & & & & FCR & & & & & \\
\hline \multirow[t]{2}{*}{$90-100$} & & & & & & & & & $\mathrm{IF} / \mathrm{fcr}$ & & & & & $2 \mathrm{fcr}$ \\
\hline & clay & sand & sand & clay & & sand & sand & sand & & & sand & clay & sand & clay \\
\hline \multirow[t]{2}{*}{$100-110$} & & & & & & & & & FCR & & & & & \\
\hline & & & & & & & & & & & & & & \\
\hline \multicolumn{15}{|l|}{ 110-120 } \\
\hline & & & & & clay & & & & sand & & & & & \\
\hline & $\begin{array}{l}\text { Key: } \\
\text { fcr-fir }\end{array}$ & & terior $\mathrm{F}$ & & IF-Interior & $\begin{array}{l}\text { Flake; UI } \\
\text { el Shell }\end{array}$ & & & & & & & k>1"; & \\
\hline
\end{tabular}

to 460 feet. It is located in an open field along a sideslope overlooking an intermittent drainage of McLaughlin Creek. Patilo complex soils (PaE) support the growth of tall grasses in the open field, and oak, and juniper in the surrounding wooded area. Surface visibility was approximately 30 percent.

Levels of Work and Results

This site was first recorded by Skelton and
Freeman in 1979, and revisited by Robinson et al. in 1997. In 1979, a 1-x-2-m test unit was excavated and the recovered artifacts included 1 primary flake, 1 secondary flake, 19 interior flakes, 7 chips, and 10 pieces of thermally fractured stone. They also noted an exposed cluster of firecracked rock on the creek's edge, but could not determine if this was a natural or cultural feature. In 1997, Robinson reported 4 flakes found in a single shovel test. 


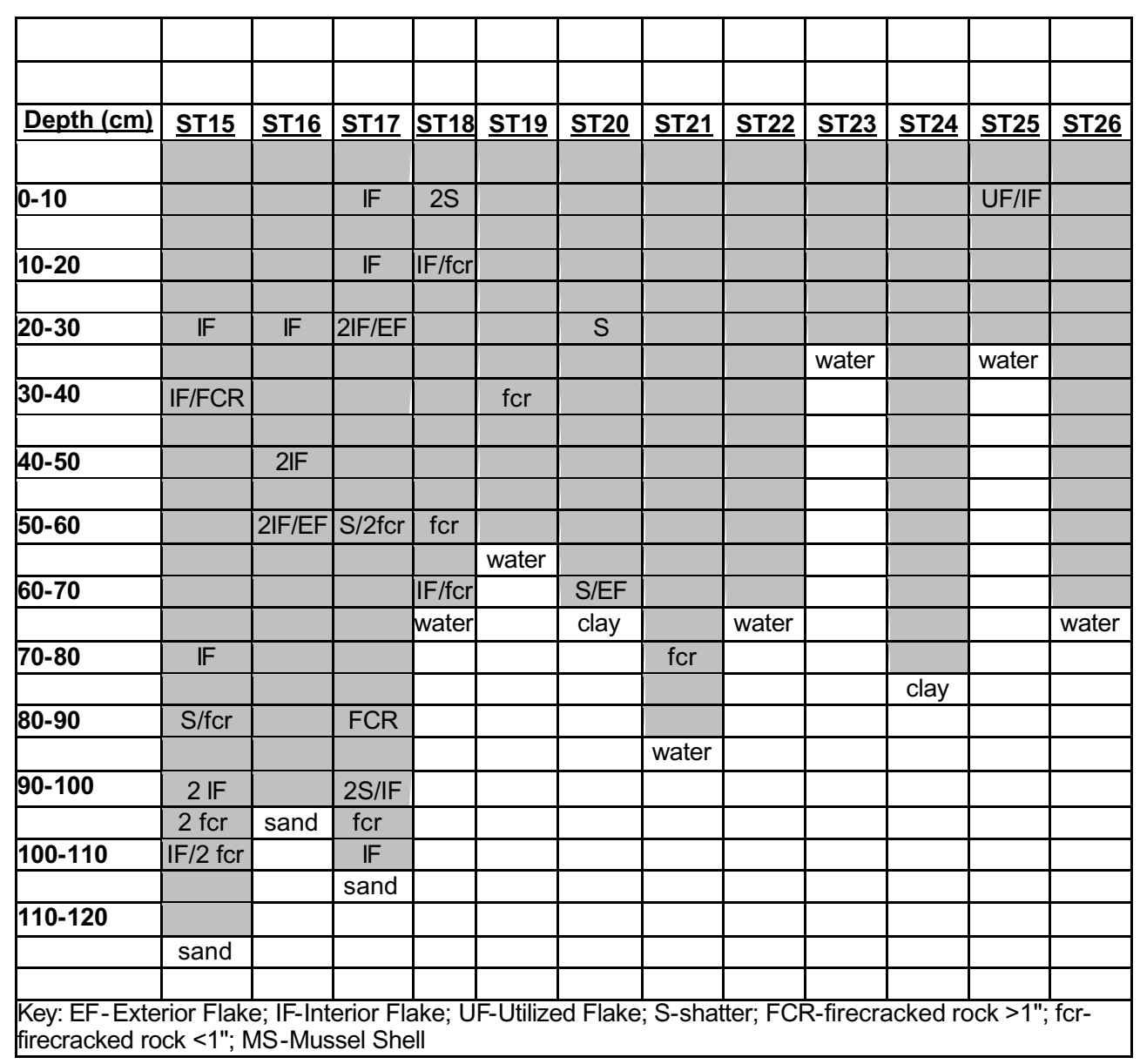

An ephemeral scatter of flakes was observed across the site, on rodent burrow backdirt. CAS dug 26 shovel tests that yielded 26 small $(<1 ")$ pieces of firecracked rock, 19 larger ( $>1 ")$ pieces of firecracked rock, 45 interior flakes, 8 pieces of lithic shatter, 5 utilized flakes, 4 exterior flakes, and 1 mussel shell(Table 4-7). A probable hearth feature was discovered on the southeastern edge of Shovel Test 5 (see Figure 4-18) from 50-60 cm below the surface.

Nineteen of twenty-six shovel tests were positive, and cultural deposits recovered as deep as 110 $\mathrm{cm}$ below the surface in shovel tests placed along the treeline near the creek (see Table 4-7 and Figure 4-18). Larger pieces of firecracked rock are buried primarily between 70 and $90 \mathrm{~cm}$ below the surface.

In 2002, CAS archaeologists observed a depression approximately 1 x 2 meters near Shovel Tests 7 and 8 that may be the unit excavated in 1979. Interestingly, our Shovel Tests 7 and 8 yielded relatively fewer artifacts than the other 17 that were positive, suggesting that excavation units in other selected areas should yield more robust data. 


\section{$41 B P 118$}

\section{Description}

Site 41BP118 (Figures 4-19 and 4-20) is a prehistoric open campsite with burned rock and an associated lithic scatter. The approximate site size is $1,095 \mathrm{~m}^{2}$, and the elevation ranges from 450 to 460 feet. The area is situated on an open sideslope adjacent to an intermittent drain-

FIGURE 4-18. REDACTED age of McLaughlin Creek. Crockett soils ( $\mathrm{CsC} 2)$ support moderately tall grasses in the open area, with dense stands of cedar, oak and pine along the drainage. A large side arroyo lies just beyond the treeline on the northwest edge. Disturbances observed include an historic fenceline running northwestsoutheast, and a 1x2-m pit approximately $70 \mathrm{~cm}$ deep, with associated backdirt piles located Figure 4-18. Site map,41BP113.

\section{Conclusions/Recommendations}

The data indicates that 41BP113 was probably used as a large open campsite. Systematic testing has indicated possibly intact cultural features buried deep below the surface. Such features have the potential to yield significant information about the paleoenvironment, and site formation processes, and can infer past subsistence and mobility patterns when applied to theoretical models. As such, the research value of this site as a single entity is considered high. In order to further evaluate its potential of this site, we recommend at least seven $1 \times 1-m$ units be placed in the immediate areas of Shovel Tests 5, 6, 9, 13, 14, 15, and 17.

on the southern portion of the site (Figure 4-20). Surface visibility was approximately 20 percent.

\section{Levels of Work and Results}

The site was initially recorded by Skelton and Freeman in 1979. In addition to observing a biface, a quartzite hammerstone, and two core fragments eroding from the edge of the slope, they excavated a $1 \times 2-m$ test unit and found a single core, 80 unmodified flakes, 3 utilized flakes, a Marshall-like dart point, a hammerstone, and 113 pieces of firecracked rock. Their excavation unit is likely the partially filled pit with associated backdirt pile observed by CAS (see Figure 4-20). In 2002, CAS-SWT personnel excavated eight 


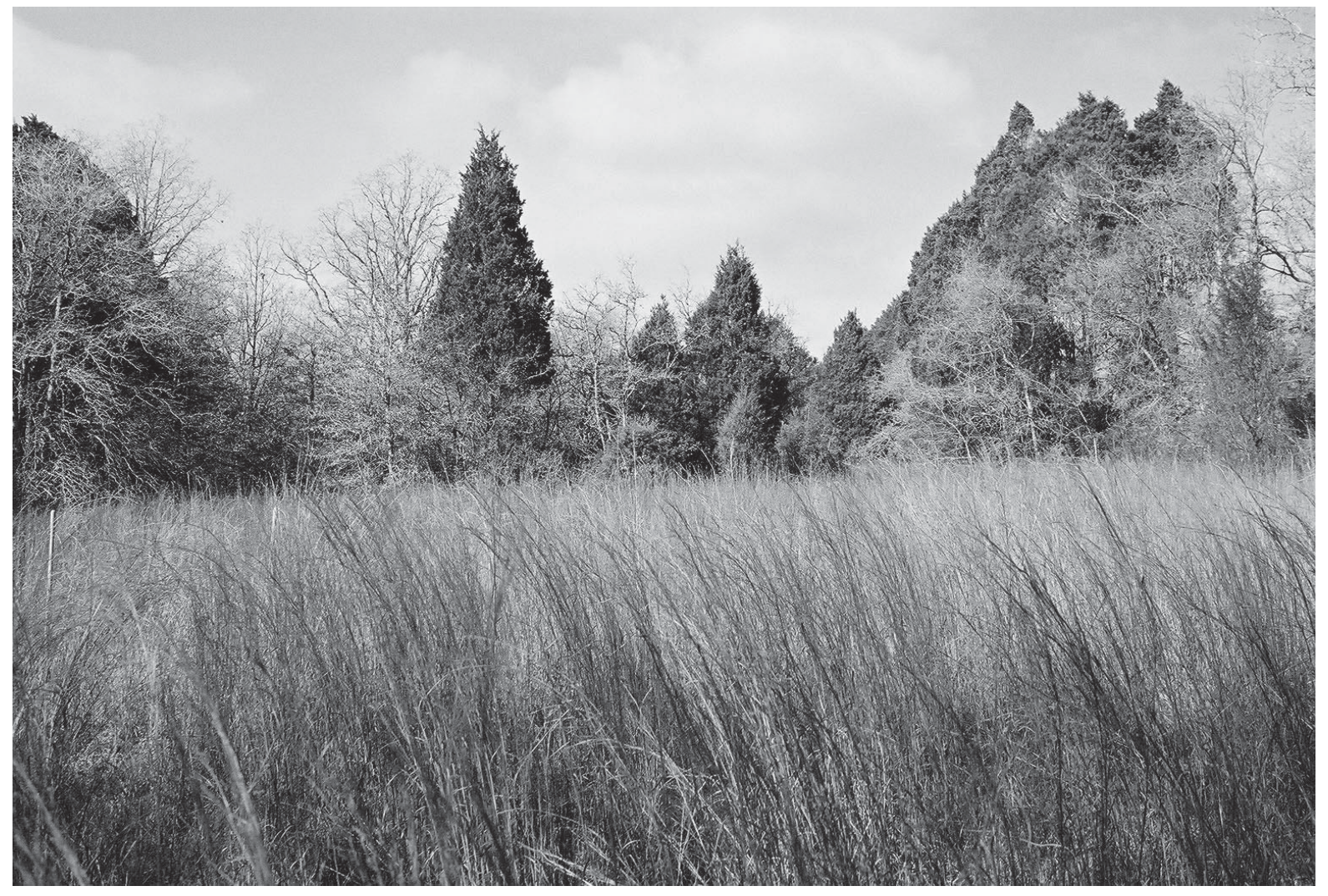

Figure 4-19. 41BP118 lies in an old-field on a sideslope overlooking McLaughlin Creek; facing northwest.

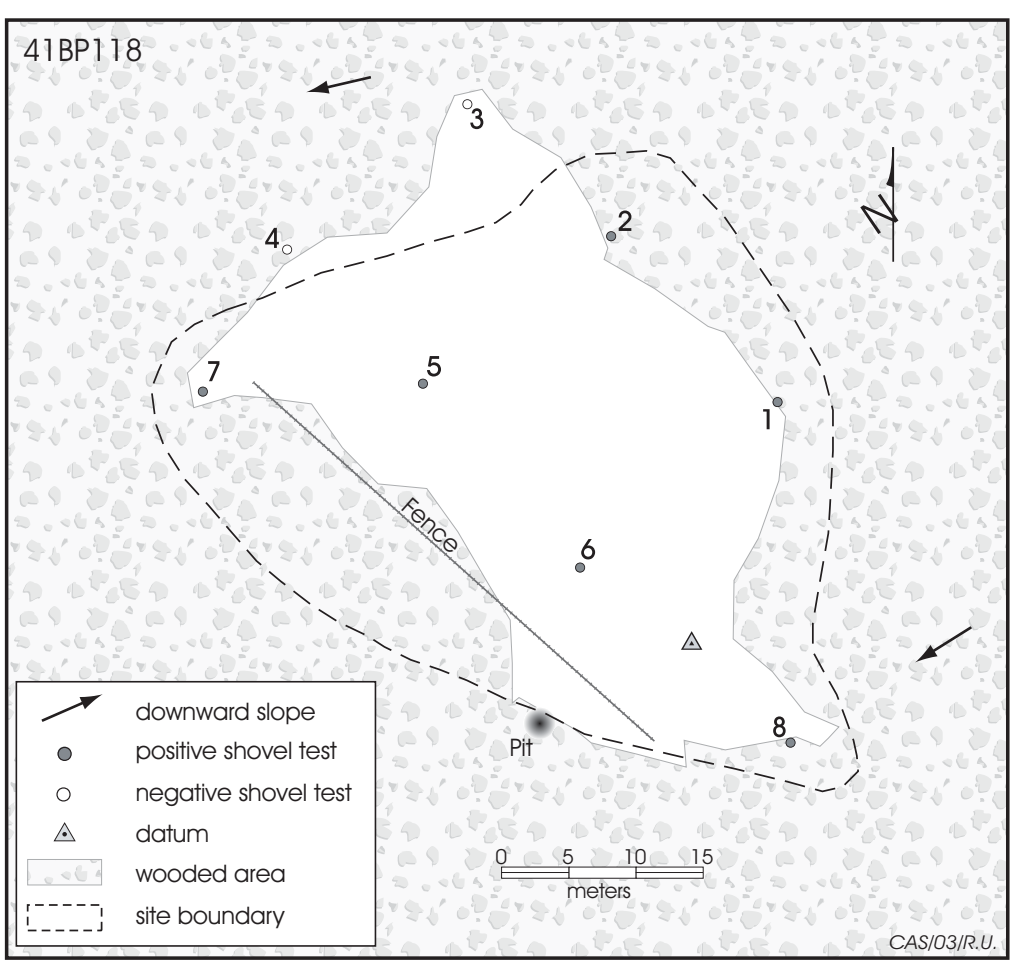

Figure4-20. Site map,41BP118. shovel tests and collected 7 large $(>1 ")$ pieces of firecracked rock, 5 smaller $(<1 ")$ pieces of firecracked rock, 8 interior flakes, 3 exterior flakes, 1 core, and 1 biface.

Skelton and Freeman recorded two firecracked rock hearth remnants between 28 and $35 \mathrm{~cm}$, and a possible A Horizon at ca. $30 \mathrm{~cm}$. CAS recovered a $>1$-inch piece of FCR between 20 and $30 \mathrm{~cm}$, along with two pieces of similar size between 80 and $90 \mathrm{~cm}$ (see Table 4-8). Shovel testing on the upperslope revealed shallow deposits of or- 
Table 4-8. 41BP118 shovel test results.

\begin{tabular}{|c|c|c|c|c|c|c|c|c|}
\hline 41BP118 & & & & & & & & \\
\hline Depth $(\mathrm{cm})$ & ST1 & ST2 & ST3 & ST4 & ST5 & ST6 & ST7 & ST8 \\
\hline \multirow[t]{2}{*}{$0-10$} & FCR & & & & $\mathrm{EF} / 2 \mathrm{FCR}$ & EF/FCR & IF & IF/C \\
\hline & & & clay & & $\mathrm{fcr}$ & $\mathrm{fcr}$ & & \\
\hline \multirow[t]{2}{*}{$10-20$} & & IF & & & & IF & & $\mathrm{IF} / \mathrm{fcr}$ \\
\hline & clay & clay & & & & & & \\
\hline $20-30$ & & & & & FCR & IF & & \\
\hline $30-40$ & & & & & fcr & & & \\
\hline $40-50$ & & & & & & B & & \\
\hline \multirow[t]{2}{*}{$50-60$} & & & & & & EF & & \\
\hline & & & & & & & & clay \\
\hline \multirow[t]{2}{*}{$60-70$} & & & & & & & fcr & \\
\hline & & & & clay & & & & \\
\hline \multicolumn{9}{|l|}{$70-80$} \\
\hline \multirow[t]{2}{*}{$80-90$} & & & & & $2 \mathrm{FCR} / \mathrm{fcr}$ & & & \\
\hline & & & & & & & water & \\
\hline $90-100$ & & & & & IF & IF & & \\
\hline \multicolumn{9}{|l|}{$100-110$} \\
\hline & & & & & sand & sand & & \\
\hline \multicolumn{9}{|l|}{$110-120$} \\
\hline \multicolumn{9}{|c|}{ Key: B-Biface; EF-Exterior Flake; IF-Interior Flake; UF-Utilized Flake; } \\
\hline C-core; & FCR-fi & recra & ked $r$ & ock $>$ & "; fcr-firecra & ked rock $<$ & & \\
\hline
\end{tabular}

tions yielded two firecracked hearth remnants, a Marshall-like dart point, and a moderate amount of artifacts, while artifacts as deep as $100 \mathrm{~cm}$ below the surface were recovered during the current shovel testing project. However, the presence of angular bedrock fragments observed well above the underlying clay during both projects may indicate colluvium deposition from the upper slope, suggesting that the artifacts are in a secondary context. Such disturbances would seriously degrade the site's integrity. Therefore, until the question of whether or not the cultural material is within the context of colluvium is answered, we assess the research value of this site as moderate. We recommend one backhoe trench be excavated in the area of Shovel Tests 5 and 6 . Should potentially intact features be encountered during trenching operations, 1x1-m units should be excavated to further evaluate the overall significance of the site.

\section{BP121}

ange clay at $20 \mathrm{~cm}$. Although the lower portion of the site contains much deeper sands, angular bedrock fragments were observed in the shovel tests, and Skelton and Freeman noted the same during their 1979 excavation. No artifacts were observed on the surface in 2002.

\section{Conclusions/Recommendations}

In its current condition, this site appears to have been used as a temporary campsite where limited lithic reduction activities occurred. Initial investiga-

\section{Description}

Site 41BP121 (Figures 4-21 and 4-22) is a prehistoric open campsite with burned rock and an associated lithic scatter. The approximate site size is $37,582 \mathrm{~m}^{2}$, and ranges in elevation from 455 to 465 feet. It is situated on a sideslope in a generally wooded area with Demona loamy fine sand (DeC) supporting stands of juniper, oak, and mesquite. New Road has been cut through the center of the site. Soils on the northern portion are generally eroded, exposing shallow deposits of red and gray 


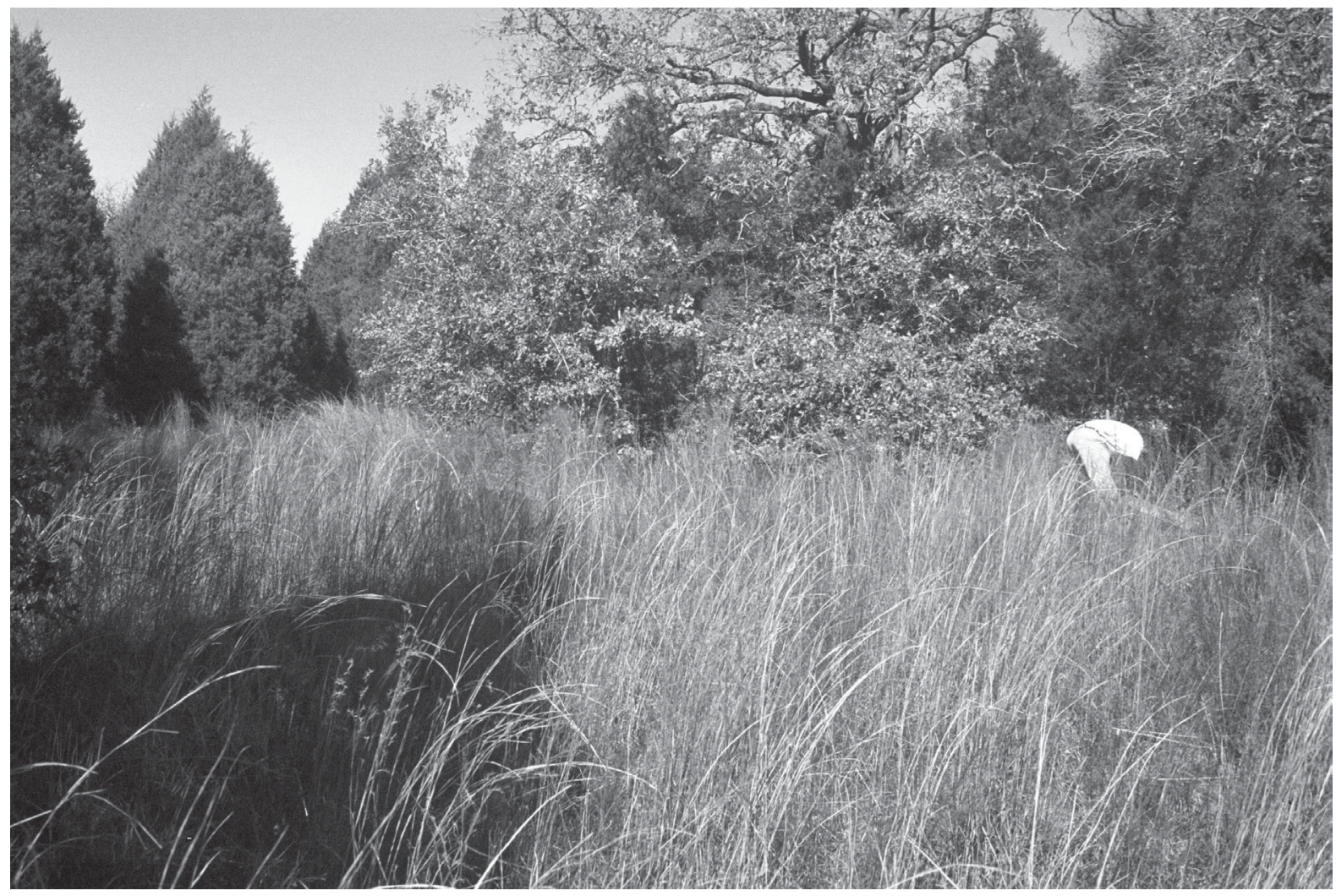

Figure 4-21. 41BP121 is situated on a gentle sideslope; photo taken facing north.

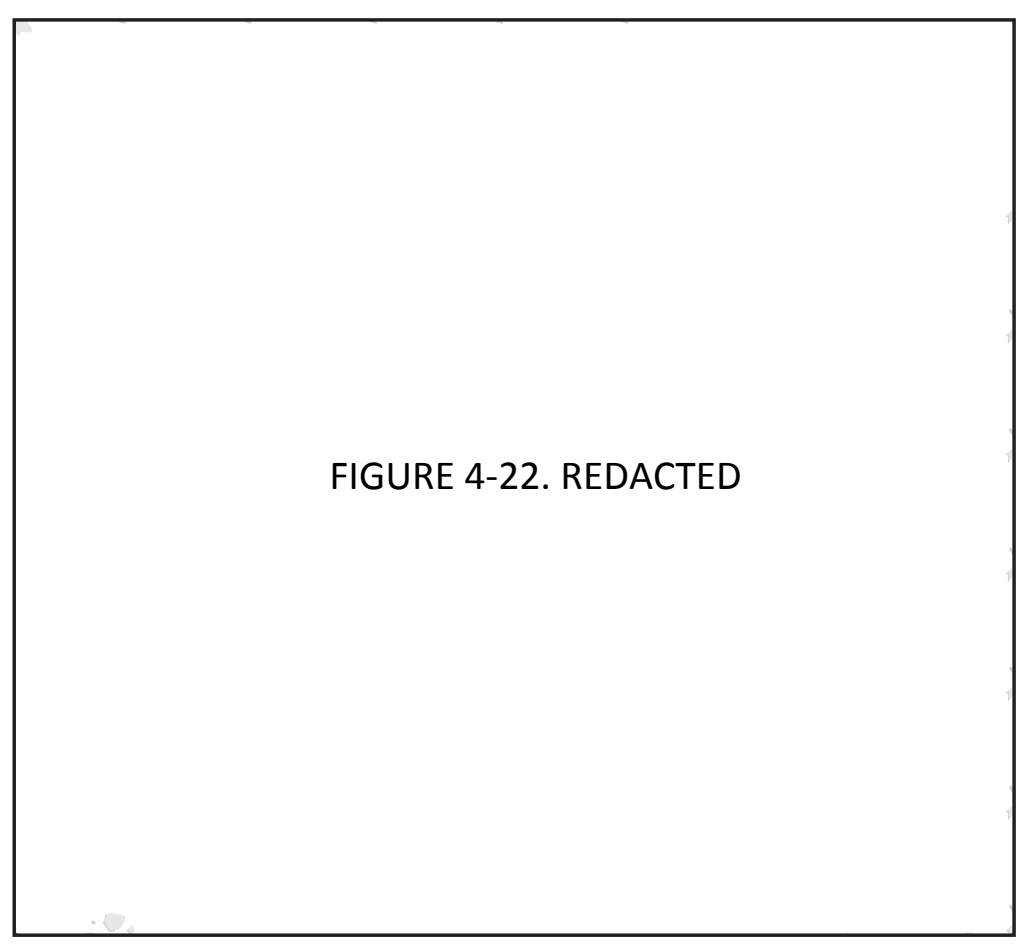

Figure 4-22. Site map,41BP121. clay, while the soils on the southern portion are deeper. Surface visibility was approximately 30 percent.

\section{Levels of Work and Results}

The site was initially recorded by Skeleton and Freeman in 1979, and subsequently revisited by Robinson et al. in 1997. In 1979, a 1x2-m excavation unit excavated in $25-\mathrm{cm}$ levels yielded 383 unmodifiedflakes, 5 utilized flakes, 1 Montell-like dart point, 13 cores, 1 hammerstone, and 377 pieces of firecracked rock. Data in Table 4-9 was derived from Skelton and Freeman(1979). Although rodent burrows were observed, the pres- 
ence of a hearth feature near the bottom of Level $3(50-75 \mathrm{~cm})$ suggested that portions of the site were intact. During their 1997 revisit, Robinson et al. found two flakes and two pieces of burned rock in one of three shovel tests excavated.
Relocating the site in 2002 proved challenging. While reviewing the ATLAS site files we found that the digitized UTM coordinates from Robinson et al. in 1997 were $32 \mathrm{~m}$ south and $146 \mathrm{~m}$ west of the 1979 coordinates given by Skelton and Freeman. There-

Table 4-9. Results of excavations in 1979.

\begin{tabular}{|c|c|c|}
\hline Depth (cm) & Soil Observations & Cultural Material \\
\hline $0-25$ & $\begin{array}{c}\text { Loose sand; extensive rodent } \\
\text { burrowing }\end{array}$ & 131 flakes; five cores, 1 hammerstone, 121 FCR \\
\hline $25-50$ & Loose sand & 193 pieces of chipped stone; 45 FCR \\
\hline $50-75$ & Loose sand & $\begin{array}{c}\text { 74 pieces of chipped stone; 1 Montell-like dart point; } \\
128 \text { FCR, w/hearth }\end{array}$ \\
\hline
\end{tabular}

Table 4-10. 41BP121 shovel test results.

\begin{tabular}{|c|c|c|c|c|c|c|c|c|c|c|c|c|c|c|c|c|c|}
\hline 41BP121 & & & & & & & & & & & & & & & & & \\
\hline Depth $(\mathrm{cm})$ & ST1 & ST2 & ST3 & ST4 & ST5 & ST6 & ST7 & ST8 & ST9 & $\underline{\text { ST10 }}$ & $\underline{\text { ST11 }}$ & ST12 & $\underline{\text { ST13 }}$ & ST14 & \begin{tabular}{|l} 
ST15 \\
\end{tabular} & \begin{tabular}{|l} 
ST16 \\
\end{tabular} & ST17 \\
\hline $0-10$ & & & & & & & & & & & & & $\mathrm{fcr}$ & & $\mathrm{fcr} / \mathrm{ClG}$ & fcr & \\
\hline & & & & & & & & & & & & & & & $\mathrm{BrG}$ & & \\
\hline $10-20$ & & & & & EF & & & fcr & & & IF & & & & $\begin{array}{c}\mathrm{PL} / \mathrm{Cl} \\
\mathrm{G}\end{array}$ & & \\
\hline & & & & clay & & & clay & & & & & & & & $\mathrm{BrG}$ & & \\
\hline $20-30$ & $\mathrm{EF}$ & & & & & & & UF & & & & & & & 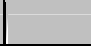 & & \\
\hline & clay & clay & & & clay & clay & & & & & & & & clay & clay & & \\
\hline $30-40$ & & & & & & & & & & UF & & & & & & & \\
\hline & & & clay & & & & & clay & & clay & & & & & & & \\
\hline $40-50$ & & & & & & & & & & & & & & & & & fcr \\
\hline & & & & & & & & & clay & & & & & & & & \\
\hline $50-60$ & & & & & & & & & & & & & & & & & \\
\hline & & & & & & & & & & & clay & & & & & water & clay \\
\hline $60-70$ & & & & & & & & & & & & & & & & & \\
\hline & & & & & & & & & & & & & & & & & \\
\hline $70-80$ & & & & & & & & & & & & & & & & & \\
\hline & & & & & & & & & & & & & & & & & \\
\hline $80-90$ & & & & & & & & & & & & & & & & & \\
\hline & & & & & & & & & & & & & clay & & & & \\
\hline $90-100$ & & & & & & & & & & & & & & & & & \\
\hline & & & & & & & & & & & & sand & & & & & \\
\hline $100-110$ & & & & & & & & & & & & & & & & & \\
\hline & & & & & & & & & & & & & & & & & \\
\hline $110-120$ & & & & & & & & & & & & & & & & & \\
\hline & Key: & IF-Inte & erior $\mathrm{F}$ & lake; & UF-Ut & ilized & Flake; & ; PL-F & Potlid & fcr-fire & acked & rock <1" & & & & & \\
\hline & BrG- & light b & rown & glass; & CIG-C & lear $\mathrm{g}$ & glass & & & & & & & & & & \\
\hline
\end{tabular}


fore, in 2003, we shovel tested in both locations, and designated them Areas A and B for management purposes only. Area A is in the general area of UTM coordinates provided after the 1997 investigations; Area B is in the general area of UTM coordinates provided after the 1979 investigations. The results of our shovel testing in 2003 indicates that the site boundary does in fact extend across both areas. Area B more closely matches the general site description given by Skelton and Freeman, and the results of our shovel tests closely resemble the results of the 1x2-m unit excavated by Skelton and Freeman (see Table 4-9).

CAS personnel excavated a total of 30 shovel tests across the two areas and collected 15 interior flakes, 7 exterior flakes, 3 utilized flakes, 5 large $(>1 ")$ pieces of firecracked rock, 8 smaller $(<1 ")$ pieces of firecracked rock, 1 potlid, 2 pieces of clear glass, and 2 pieces of brown glass (Table 4-

Table 4-10. (Continued)

\begin{tabular}{|c|c|c|c|c|c|c|c|c|c|c|c|c|c|}
\hline \multicolumn{14}{|l|}{ 41BP121 } \\
\hline Depth $(\mathrm{cm})$ & ST18 & ST19 & ST20 & ST21 & ST22 & ST23 & ST24 & ST25 & ST26 & ST27 & ST28 & ST29 & ST30 \\
\hline $0-10$ & & & & & & & IF & & & & & & \\
\hline \multirow[t]{2}{*}{$10-20$} & & & & & & & & & & & & & $\mathrm{FF} / \mathrm{F}$ \\
\hline & & & & & & & & & & & & clay & UF \\
\hline $20-30$ & & & fcr & & & $\mathrm{IF} / \mathrm{fcr}$ & & & & & & & IF \\
\hline \multirow[t]{2}{*}{$30-40$} & & & & & & & $\mathrm{Bu}$ & & IF & & & & $\mathrm{EF} / \mathrm{IF}$ \\
\hline & clay & & clay & & & & & & & & & & \\
\hline \multirow[t]{2}{*}{$40-50$} & & & & & EF & & IF & & & & & & IF \\
\hline & & & & & & & & & & & & & \\
\hline $50-60$ & & & & & FCR & EF & & & & & & & FCR \\
\hline \multirow{3}{*}{ 60-70 } & & & & & & & & & . & 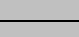 & & & \\
\hline & & & & & & IF & IF & & & & & & $2 \mathrm{FCR}$ \\
\hline & & clay & & & & & & & & & & & \\
\hline \multirow[t]{2}{*}{$70-80$} & & & & & & & & & & & & & $\mathrm{EF} / \mathrm{IF}$ \\
\hline & & & & & & & & clay & & & & & \\
\hline $80-90$ & & & & & & & & & $\mathrm{IF} / \mathrm{fcr}$ & & & & IF \\
\hline \multirow[t]{2}{*}{$90-100$} & & & & & & & IF & & & & & & FCR \\
\hline & & & & clay & clay & sand & clay & & sand & sand & sand & & \\
\hline \multirow[t]{3}{*}{$100-110$} & & & & & & & & & & & & & IF \\
\hline & & & & & & & & & & & & & sand \\
\hline & & & & & & & & & & & & & \\
\hline
\end{tabular}


10). Although Skelton and Freeman noted lithic debitage on the surface, no artifacts were observed on the surface in 2002 .

When CAS revisited the site in 2003, numerous gravels were observed in the newly bladed road, cut 50-60 cm deep through the center of the site (see Figure 4-22). Among the gravels were a bifacial core and an ephemeral scatter of flakes. The only other artifacts observed on the surface and off the road were a firecracked rock, and a flake on a gopher mound - both in Area B.

\section{Conclusions/Recommendations}

Shovel Tests 1 through 15 excavated in the northern portion of the site we designated Area A indicate that soils are are generally shallow. However, in the southern portion of the site we designated Area B, soils are generally much deeper and cultural material was recovered to $110 \mathrm{~cm}$ below the surface (see Table 4-10). Unfortunately, Skelton and Freeman's sketch map and photograph (1979:49) do not show the location of their excavation unit. However, a depression observed in 2003 near Shovel test 22 "may" be from their excavations.

A high potential for finding possibly intact cultural features and associated material buried deep below any disturbed zone is manifested by the presence of a hearth feature documented between 50-75 cm in 1979, lithic debitage appearing in the road cutbank between $50-60 \mathrm{~cm}$, and deeply buried deposits recovered from Shovel Tests 22-24, 26, and 30. However, before an assessment can be made regarding NRHP eligibility, we recommend at least three backhoe trenches units be placed near Shovel Tests 22-24, 26, and 30 in Area B. Should potentially intact features be encountered during

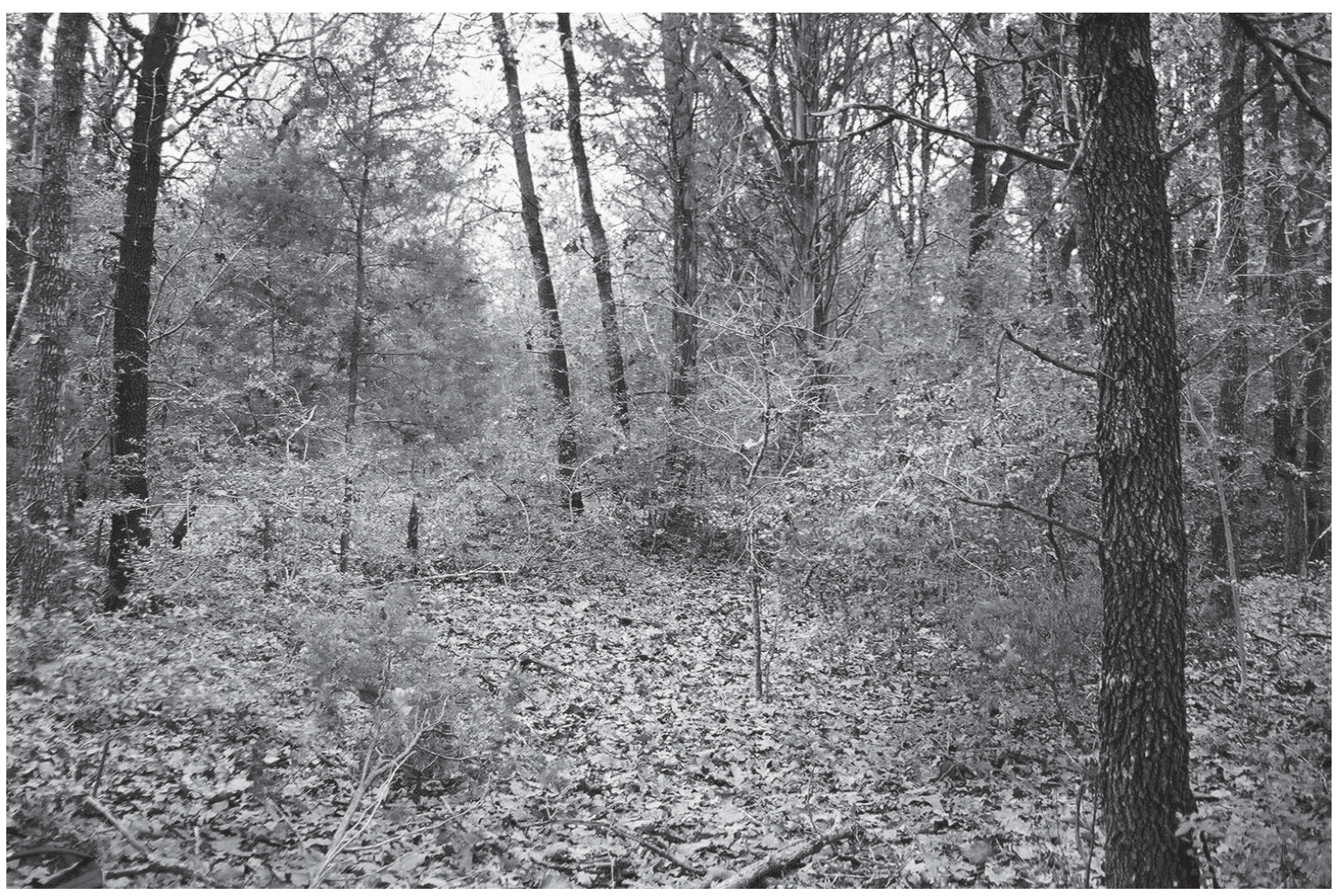

Figure 4-23. 41BP123 sets on a wooded sideslope above a tributary of McLaughlin Creek; facing south. 
FIGURE 4-24. REDACTED

Figure 4-24. Site map, 41BP123.

trenching operations, 1x1-m units should be excavated to further evaluate the overall significance of the site.

\section{BP123}

\section{Description}

41BP123 (Figures 4-23 and 4-24) is a prehistoric open campsite covering approximately 2,400 $\mathrm{m}^{2}$, and ranging in elevation from 450 to 460 feet. It lies in a mixed pine and cedar woodland interspersed with open grassy areas supported by Demona loamy fine sand $(\mathrm{DeC})$. The area is located on a sideslope overlooking the floodplain of a tributary of McLaughlin Creek. A bulldozed road has been cut through the site, and intensive clearing of trees has occurred. Surface visibility in January 2003 was approximately 10 percent.

Levels of Work and Results

A 1x1-m test unit excavated in 1979 by Skelton and Freeman yielded 60 flakes and chips, 72 pieces of burned rock, and 4 cores. However, most were recovered from within either disturbed deposits or lying on gravelly clay (see Table 4-11).

In 2002, CAS-SWT personnel excavated sixteen shovel tests (STs 1-16), but found only five small $(<1$ ") pieces of firecracked rock (Table 4-12). It seemed problematic that the results of our shovel testing in terms of artifact quantities were not nearly as robust as the amount recovered in Skelton and Freeman's single test unit. We initially placed Shovel Tests 1 through 5 in the immediate area; when results were less than expected, we placed an additional 11 tests over an ever-expanding area, with negative results. Believing that perhaps we had erred in navigating to the correct coordinates, we double-checked TARL's digitized UTM coordinates provided on

Table 4-11. Results of excavations in 1979.

\begin{tabular}{|l|l|l|}
\hline \multicolumn{1}{|c|}{ Depth (cm) } & \multicolumn{1}{|c|}{ Soil Observations } & \multicolumn{1}{c|}{ Cultural Material } \\
\hline $0-25$ & $\begin{array}{l}\text { Loose sand; extensive rodent } \\
\text { burrowing }\end{array}$ & 23 flakes and chips; 32 firecracked rocks \\
\hline $25-50$ & Loose sand; rodent burrowing & $\begin{array}{l}13 \text { flakes; 4 chips, 2 cores, 13 firecracked } \\
\text { rocks }\end{array}$ \\
\hline $50-75$ & Sandy, gravelly clay @65 cm & $\begin{array}{l}14 \text { flakes, 6 chips, 2 cores; 27 firecracked } \\
\text { rocks (most lying on clay @75 cm) }\end{array}$ \\
\hline
\end{tabular}




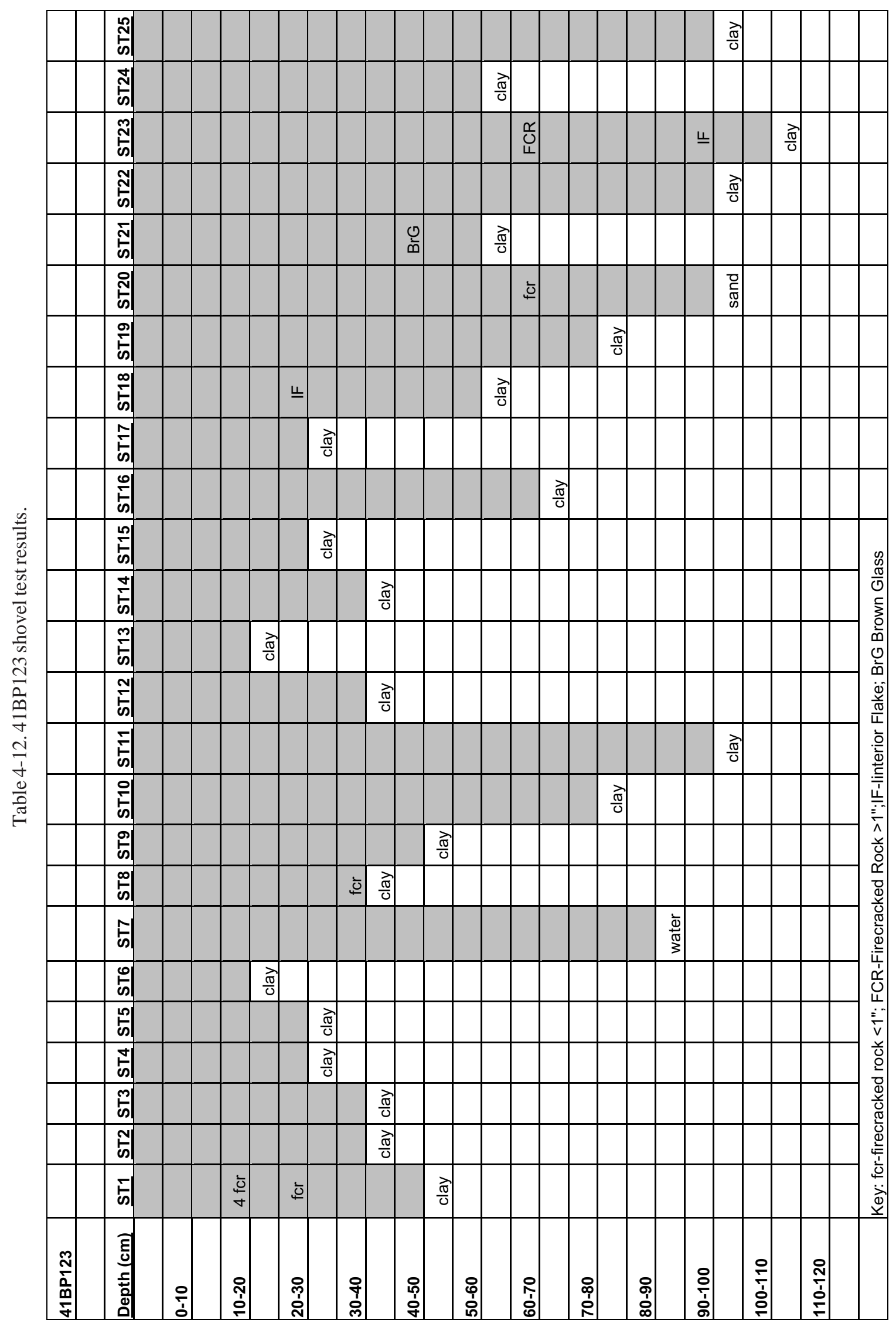


the Texas Historical Commission's ATLAS site. Then using both a handheld compass as well as a GPS, we navigated three more times to the UTM coordinates reported, and arrived at the same spot each time.

Following that, we double-checked for details, the site form prepared by Skelton and Freeman in 1979, as well as their report of excavations (1979:5152). The UTM coordinates given by Skelton and Freeman were $26 \mathrm{~m}$ south, and $84 \mathrm{~m}$ east of those digitized by TARL. Therefore, in 2003 we returned to the area of Skelton and Freeman's UTM coordinates and placed an additional nine shovel tests (STs 17-25). As shown in Table 4-12, we recovered only a single flake and a piece of brown glass.

\section{Conclusions/Recommendations}

Based upon the stark contrasts in artifact quantities recovered between the 1979 excavations compared to our 2002-2003 shovel test results, we suspect that the site has been heavily disturbed by bulldozing and tree clearing. Therefore, the research value of this site as a single entity is considered minimal. Its value increases only slightly when considered in context with other small temporary campsites in the region. As such, we assess the ability of this site to provide further significant information to the prehistory of the region as minimal; it is not eligible for nomination to the National Register of Historic Places, and no further testing is recommended.

\section{BP138}

\section{Description}

The prehistoric component at 41BP138 consists of a lithic scatter covering approximately 6,700

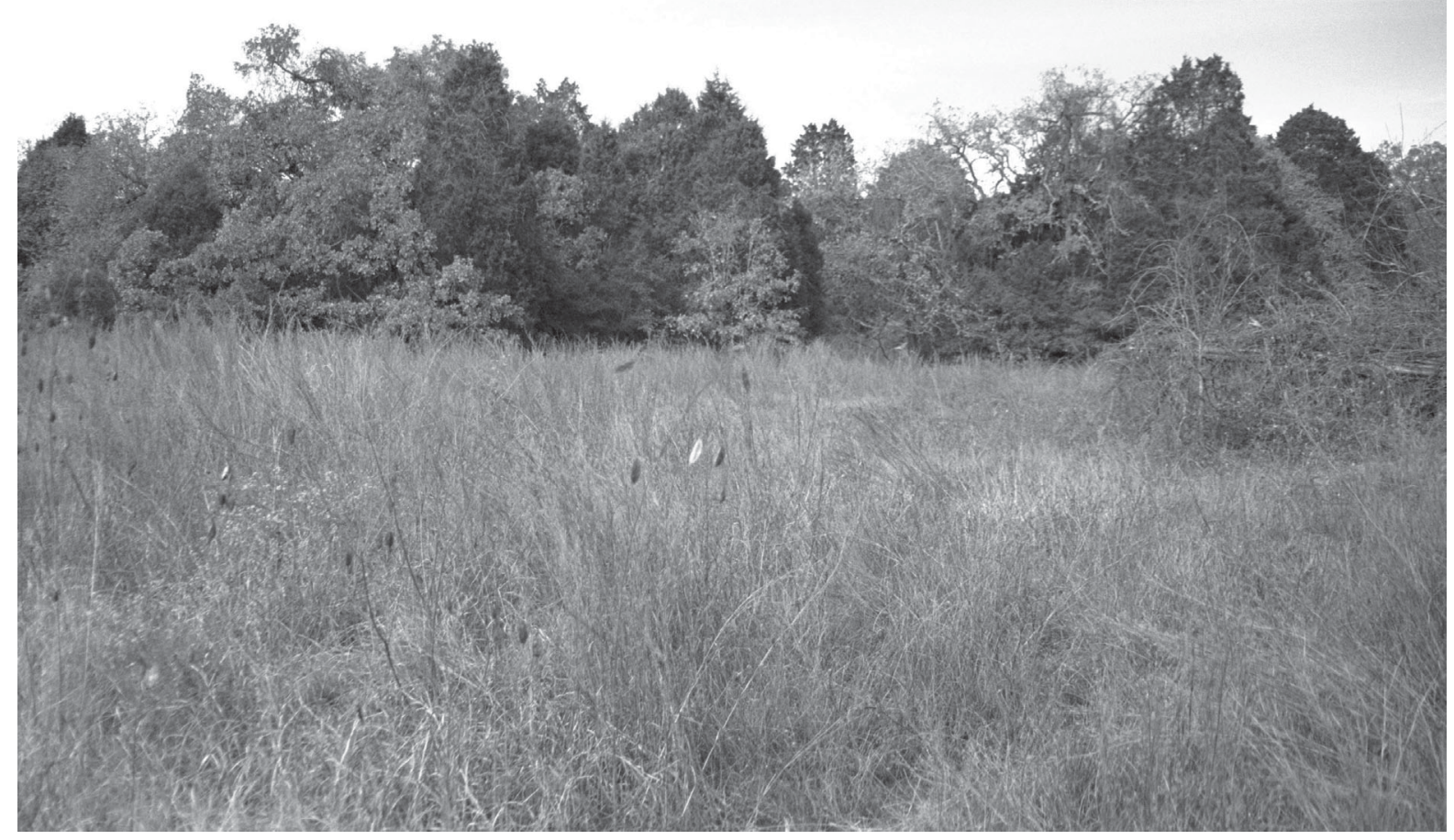

Figure 4-25. A lithic scatter was found at 41BP138, situated in an old-field; facing west. 


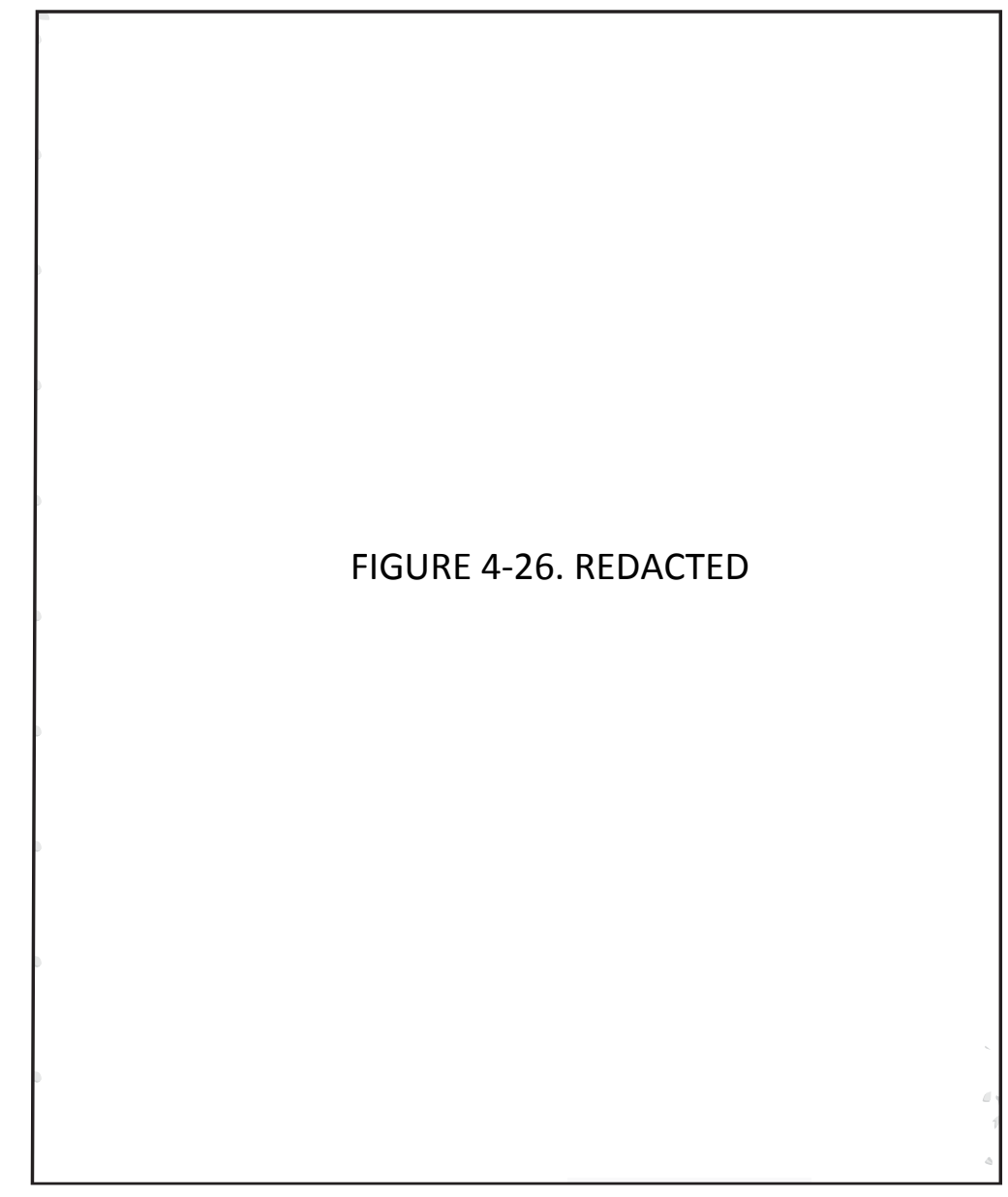

Figure 4-26. Site map,41BP138.

$\mathrm{m}^{2}$ (Figures 4-25 and 4-26). Disturbances include the construction of a modern road, agricultural cultivation, a clay borrow pit, the bulldozing of one historic structure, and the construction of a fence to protect a second historic structure (see Section II for a discussion of the Historic component). However, the disturbances noted at the site occurred before the identification of the prehistoric component in 1997. The bulldozing of the structure likely occurred relatively soon after the military acquired the property, the borrow pit was dug prior to 1997 , and Wine Cellar Road is depicted on USGS Topo maps prior to 1997. Ranging in elevation from 440 450 feet, it lies on a ridge in a generally open area. Scattered stands of oak, and tall grasses are sup- ported by Demona loamy fine sand (DeC). Surface visibility was approximately 30 percent.

Levels of Work and Results

Although the Historic component of this site was first recorded in 1979 by Skelton and Freeman, no prehistoric component was observed. However, when revisited in 1997 (Robinson et al. 2001), a biface was collected from the surface, a dense scatter of lithic debitage was noted, and chipped stone was recovered from two shovel tests. In 2002, CAS-SWT personnel excavated 44 shovel tests, recovering 6 interior flakes, 1 exterior flake, 1 utilized flake, and a piece of lithic shatter ([in addition to 31 pieces of historic material and 3 bullets] [see Table 4-13). A few flakes were visible only on the road surface.

\section{Conclusions/Recommendations}

The prehistoric component of this site has been heavily impacted by historic occupation and modern construction, mixing historic artifacts with prehistoric material, and thus significantly degrading the site's integrity. The results of shovel testing in 2002 revealed no evidence of buried features, and only limited, widely scattered debitage below the surface (Table 4-13 and Figure 4-26). Therefore, the potential of the prehistoric component of this site to contribute significant information to our knowledge of prehistory is minimal. As such, we assess the prehistoric component as ineligible for nomination to the National Register of Historic 


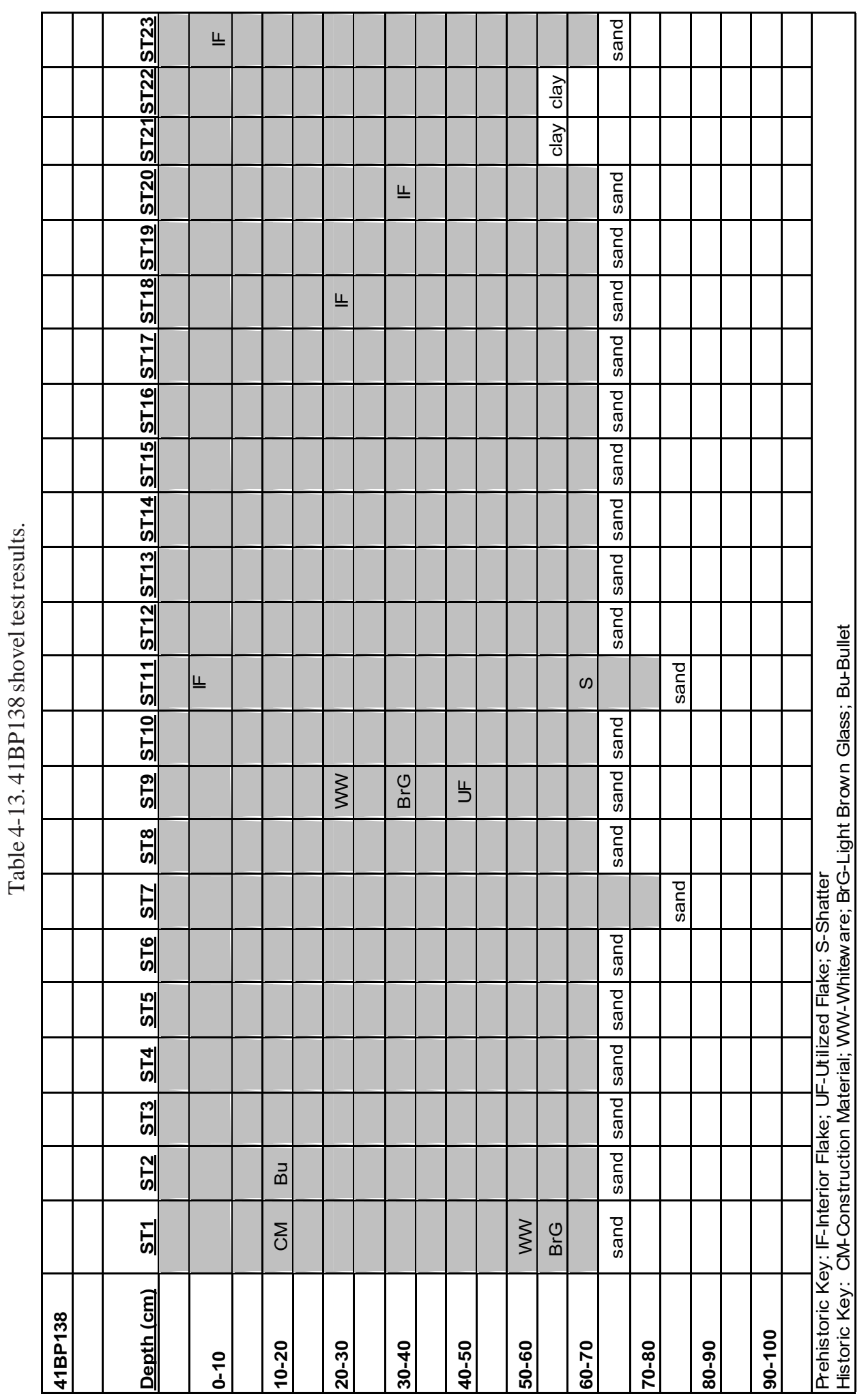




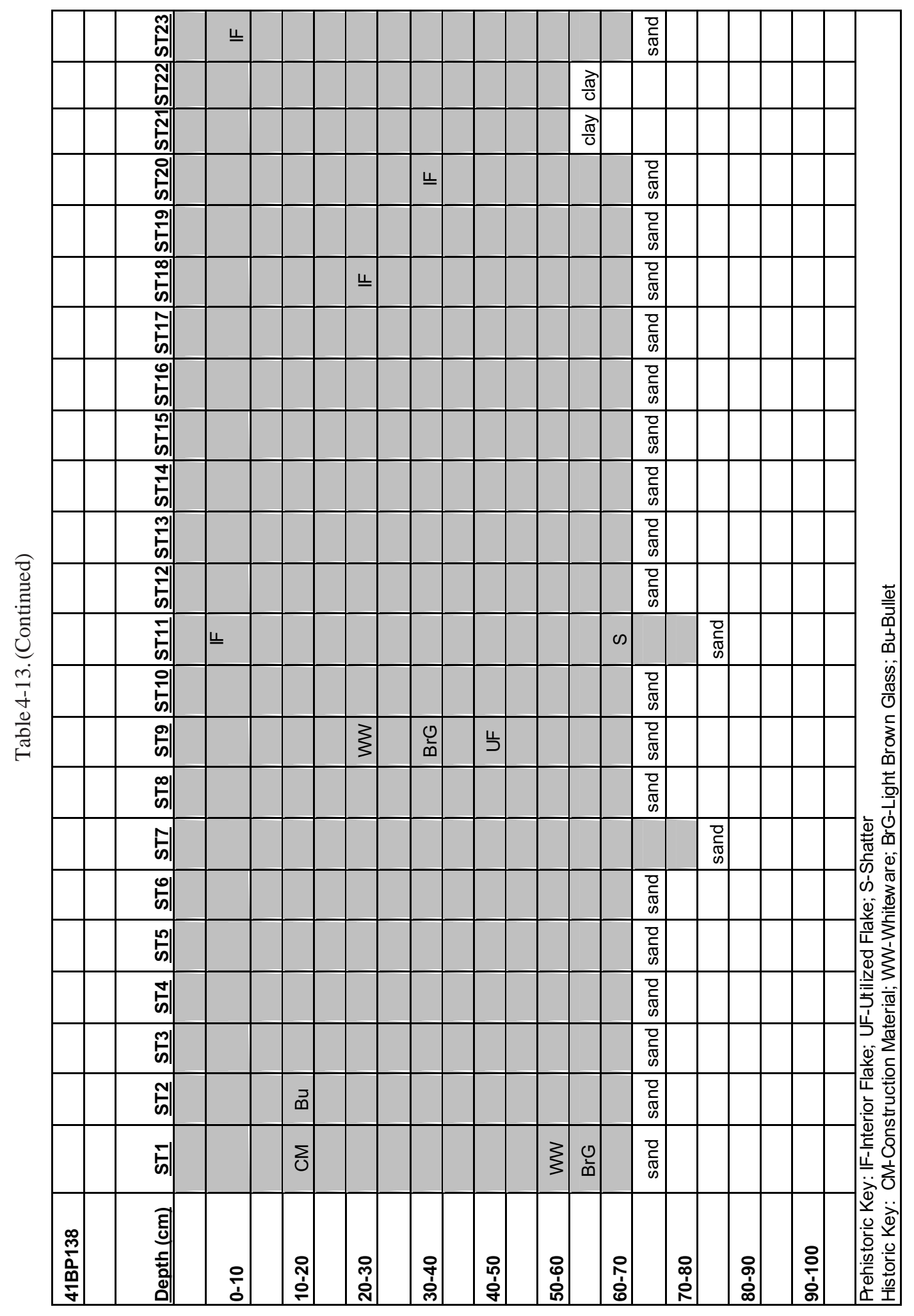


Places, and no further work is recommended.

\section{BP430}

\section{Description}

41BP430 (Figures 4-27 and 4-28) is a prehistoric lithic scatter located $685 \mathrm{~m}$ northeast of McLaughlin Creek. Although a historic component on the site covers approximately $15,000 \mathrm{~m}^{2}$ and, the prehistoric component consists of a single flake. It is situated on and around a small hill ranging in elevation from 500 510 feet. There are tall grasses

\section{FIGURE 4-27. REDACTED}

Figure 4-27. Site map, 41BP430.

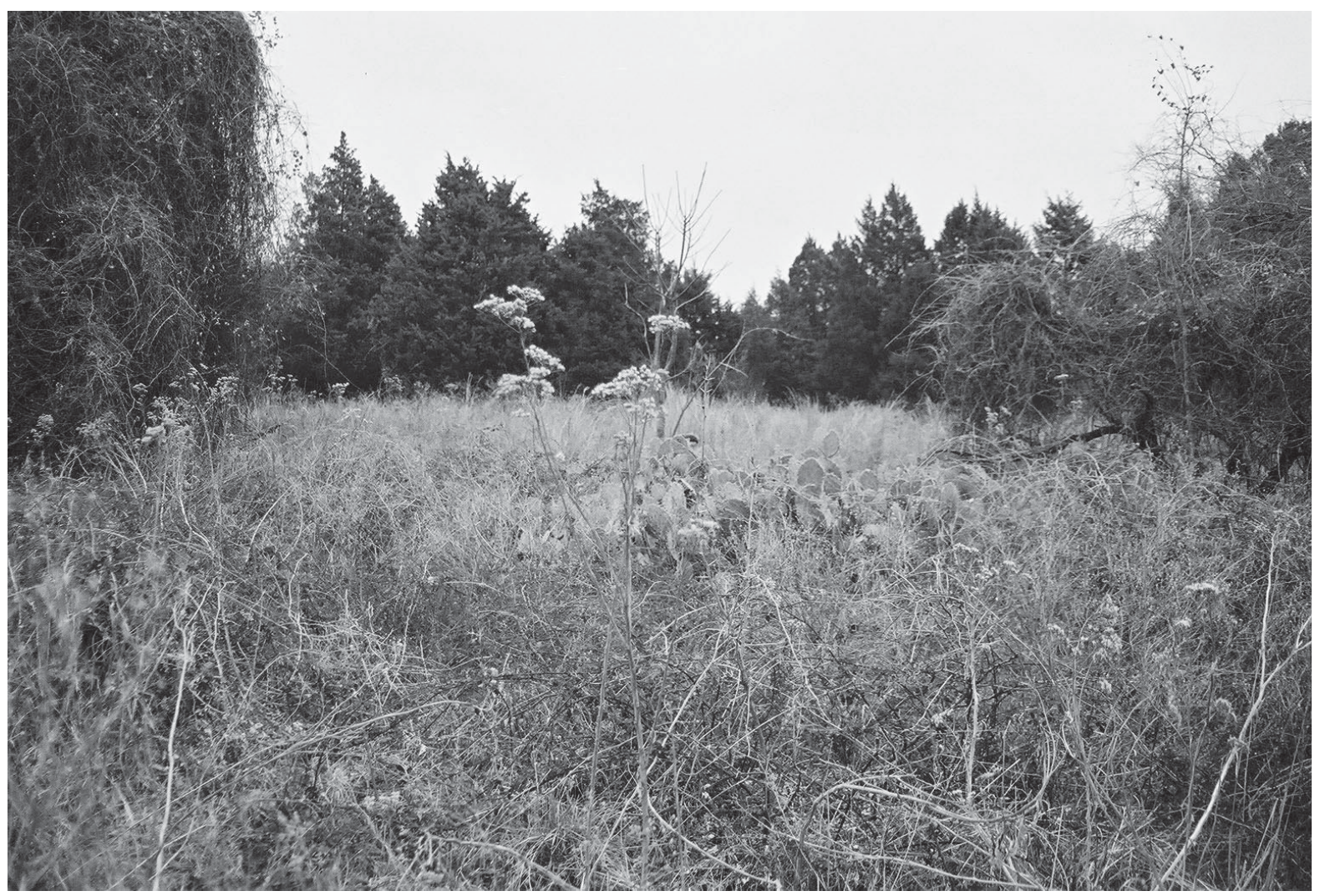

Figure 4-28. An ephemeral lithic scatter was found at 41BP430, on a historic farmstead situated in the uplands; facing north. 
on the hill, with a moderately dense surrounding treeline supported by Axtell fine sandy loam (AfC), and consists mainly of oak, cedar, pine, and mesquite. The area was the location of a historic homestead, which was likely bulldozed soon after the military acquired the property in the 1940's. A depression marks where the house probably stood. Other evidence of historic occupation includes large oak trees, a well, and barbwire fencing (see Section II for a discussion of the historic component). Surface visibility was approximately 30 percent.

\section{Levels of Work and Results}

In 1995, Schmidt and Cruse found a single chert flake, along with numerous historic artifacts, in a total of seven shovel tests excavated. In 2002,
CAS-SWT personnel excavated eleven shovel tests and collected 42 historic and modern artifacts, but no prehistoric material (Table 4-14). Schmidt and Cruse (1995) made no note of prehistoric debitage on the surface, nor were any observed during CAS' 2002 revisit.

\section{Conclusions/Recommendations}

The historic occupation, its subsequent bulldozing, and construction of a jeep road have all contributed negatively to the integrity of the prehistoric component at this site. Only one flake was found in a total of 18 shovel tests, no prehistoric artifacts were observed on the surface, and no features or diagnostics were found. Therefore, the research value as a single entity is considered minimal at best, and is assessed as not eligible for nomination

Table 4-14. 41BP430 shovel test results.

\begin{tabular}{|c|c|c|c|c|c|c|c|c|c|c|c|}
\hline 41BP430 & & & & & & & & & & & \\
\hline Depth (cm) & ST1 & ST2 & ST3 & ST4 & ST5 & ST6 & ST7 & ST8 & ST9 & ST10 & ST11 \\
\hline \multirow[t]{2}{*}{$0-10$} & & & & & & Bullet/ & Brown Glass & & & & \\
\hline & & & & clay & & Clear Glass & & & & clay & \\
\hline \multirow[t]{2}{*}{$10-20$} & & & & & brown snuff & & 6 Clear Glass/ & & & & \\
\hline & & & & & -bottle lip & & Brown Glass & & & & clay \\
\hline \multirow[t]{2}{*}{$20-30$} & & & & & & & 2 Ironstone/ & & & & \\
\hline & & & & & & clay & 9 Clear Glass & & clay & & \\
\hline \multirow[t]{2}{*}{$30-40$} & & & & & & & 10 Clear Glass/ & & & & \\
\hline & & & clay & & clay & & Round Nail & & & & \\
\hline \multirow[t]{2}{*}{$40-50$} & & & & & & & 3 Clear Glass/ & & & & \\
\hline & clay & & & & & & Whiteware/Metal frag & & & & \\
\hline \multirow[t]{2}{*}{$50-60$} & & & & & & & 3 Clear Glass/ & & & & \\
\hline & & & & & & & Whiteware rim & & & & \\
\hline \multicolumn{12}{|l|}{$60-70$} \\
\hline & & & & & & & clay & & & & \\
\hline \multicolumn{12}{|l|}{$70-80$} \\
\hline & & & & & & & & clay & & & \\
\hline \multicolumn{12}{|l|}{$80-90$} \\
\hline & & clay & & & & & & & & & \\
\hline $90-100$ & & & & & & & & & & & \\
\hline
\end{tabular}


to the National Register of Historic Places. We recommend no further testing

\section{BP431}

\section{Description}

Schmidt and Cruse (1995) described 41BP431 (Figures 429 and 4-30) as a prehistoric lithic scatter located on a small rise about $240 \mathrm{~m}$ northeast of McLaughlin Creek, and butted up against the edge of a private property fenceline. At the time of their visit, the site was covered in tall grasses and briars in Axtell

\section{FIGURE 4-29. REDACTED}

Figure 4-29. Site map, 41BP431.

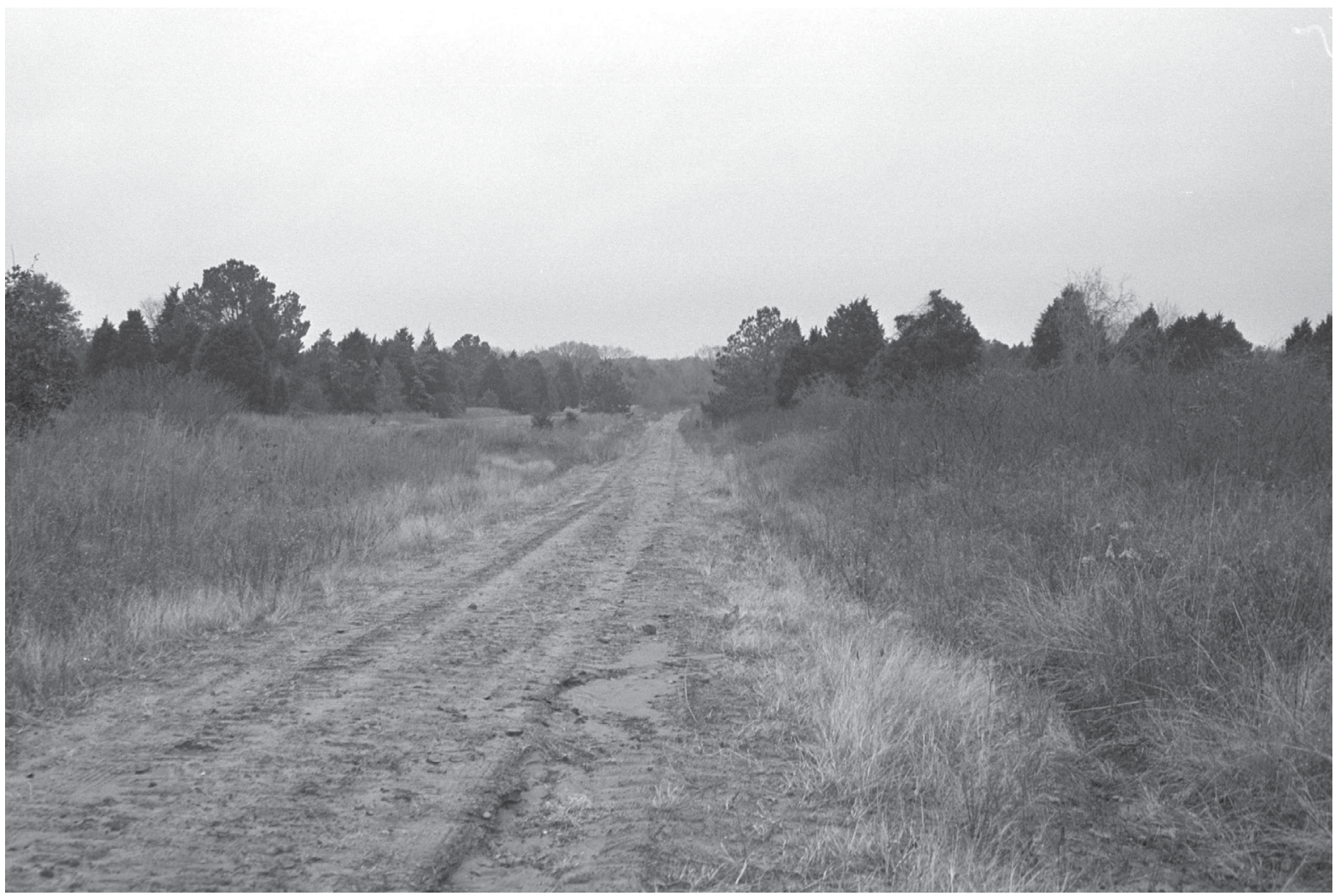

Figure 4-30. A road and pipeline are adjacent to 41BP431; facing south. 
fine sandy loam (AfC2). Their limited testing did not establish site boundaries. Although CAS archaeologists dug ten shovel tests at the two locations plotted by TARL and Schmidt and Cruse, no cultural material was found.

\section{Levels of Work and Results}

Initial investigations were conducted by Schmidt and Cruse in 1995 during a survey for a proposed pipeline route. They excavated six shovel tests within the right-of-way and found (not collected) a total of 1 tertiary chert flake, 1 heat-treated chert shatter, and charcoal between 20 and $30 \mathrm{~cm}$ below the surface. No notes were made regarding surface observations other than dense vegetation covered the site.
Table 4-15. 41BP431 shovel test results.

\begin{tabular}{|l|l|l|l|l|l|l|l|l|l|l|}
\hline 41BP431 & & & & & & & & & & \\
\hline & & & & & & & & & & \\
\hline Depth (cm) & ST1 & ST2 & ST3 & ST4 & ST5 & ST6 & ST7 & ST8 & ST9 & ST10 \\
\hline & & & & & & & & & & \\
\hline $\mathbf{0 - 1 0}$ & & & & & & & & & & \\
\hline & & & & & & & & clay & & \\
\hline $\mathbf{1 0 - 2 0}$ & & & & & & & & & & \\
\hline & & & & & & clay & & & clay & \\
\hline $\mathbf{2 0 - 3 0}$ & & & & & & & & & & \\
\hline & & & & & & & & & & \\
\hline $\mathbf{3 0 - 4 0}$ & & & & & & & & & & \\
\hline & clay & & clay & clay & clay & & clay & & & clay \\
\hline $\mathbf{4 0 - 5 0}$ & & & & & & & & & & \\
\hline & & & & & & & & & & \\
\hline $\mathbf{5 0 - 6 0}$ & & & & & & & & & & \\
\hline & & clay & & & & & & & & \\
\hline $\mathbf{6 0 - 7 0}$ & & & & & & & & & & \\
\hline
\end{tabular}

According to the State of Texas Trinomial Form submitted by Melinda Tate and Allison Bates of Espey Huston \& Associates, the site was located at UTM E667020 N3350120. According to a TARL Site Digitization Date Form filed later, the UTM is E667019 N3350145; some 25 m north of the earlier location (see Figure 4-30). In 2000, while employed at The University of Texas at San Antonio's Center for Archaeological Research, the senior author of this report returned to the area with a handheld GPS and established a site datum with a nail and an aluminum tag.

In 2002, CAS-SWT personnel relocated the UTSA datum as well as the two UTM locations given by Tate and Bates, and TARL. We double checked a quad map with the site's location plotted on it, and we reviewed the site description and photograph in Schmidt and Cruse's report (1995). We then excavated ten shovel tests but found no cultural materials. Table 4-15 indicates the depths of shovel tests before reaching the underlying culturally sterile orange clay. The road and pipeline right-of-way surfaces were examined in 2002, but only crushed gravels were observed.

\section{Conclusions/Recommendations}

A review of the site map showing the two positive shovel tests in Schmidt and Cruse's report (1995) indicates that they are approximately $12 \mathrm{~m}$ apart. Because our ten shovel tests spread across the area yielded no evidence of cultural material, our conclusion is that the site is extremely small and ephemeral, and we were not able to pinpoint it. Because of its presumably ephemeral nature we now assess the research value of this site to be minimal at best, and not eligible for nomination to the National Register of Historic Places. We recommend no further testing. 


\section{BP435}

\section{Description}

41BP435 (Figures 4-31 and 4-32) is a prehistoric open campsite with burned rock and an associated lithic scatter. The site covers approximately $2,100 \mathrm{~m}^{2}$, and lies $110 \mathrm{~m}$ west of McLaughlin Creek. It is situated on a sideslope in an open field, with four artificial terraces created for agricultural purposes. A second disturbance includes a fenced "off limits" area approximately $55 \mathrm{~m}$ long x $37 \mathrm{~m}$ wide, located on the northeastern corner of the site (see Figure 432). Axtell fine sandy loam(AfC2)

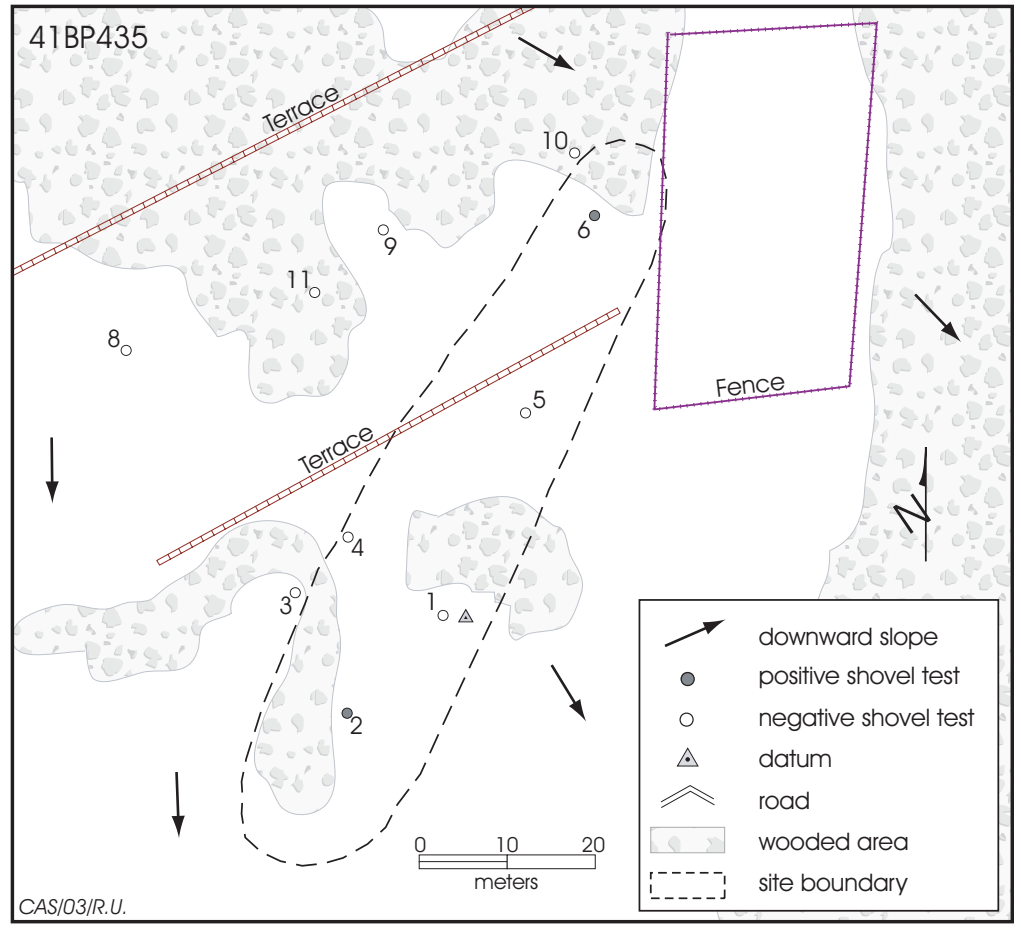

Figure 4-31. Site map, 41BP435.

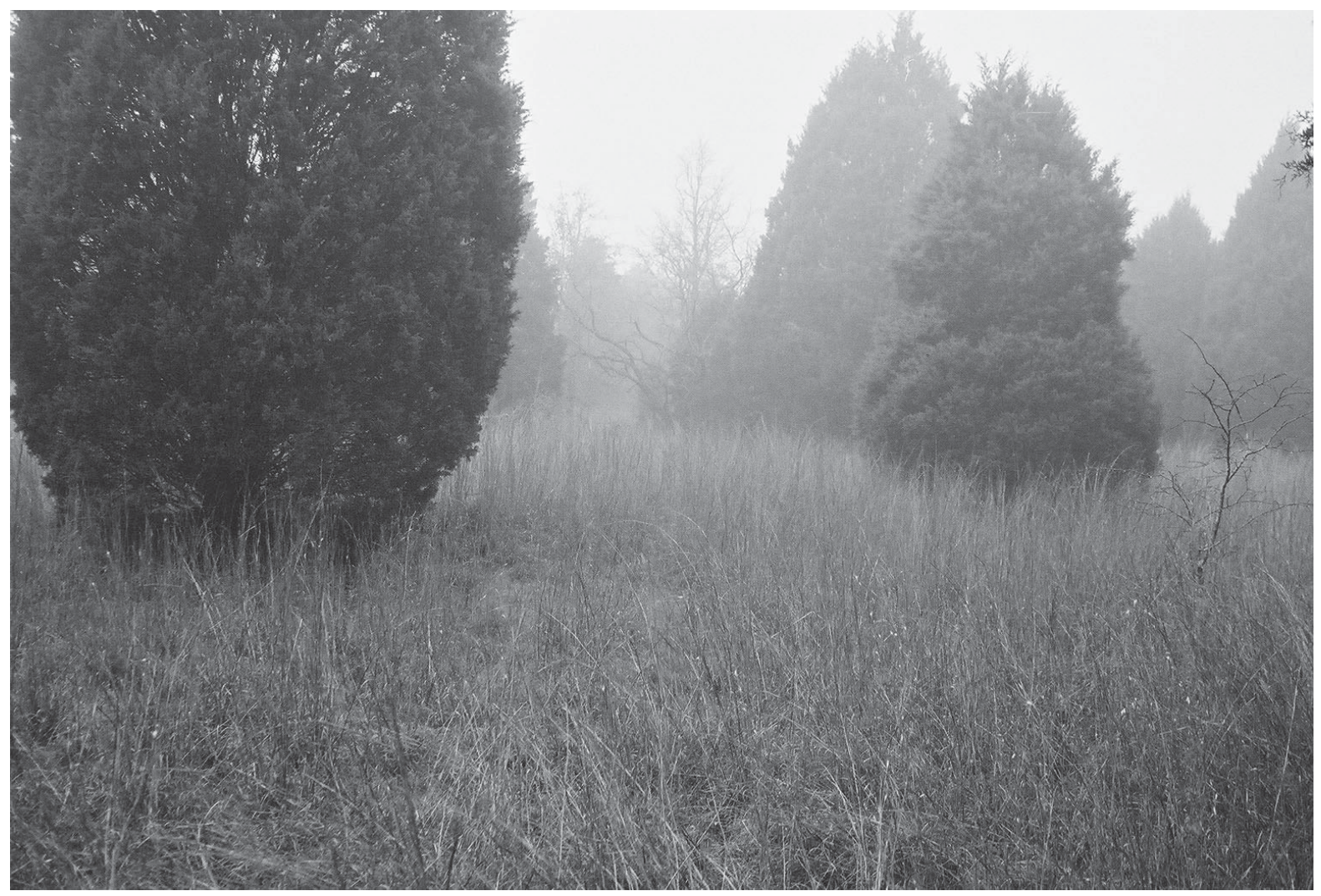

Figure 4-32. 41BP435 lies on a sideslope that has been artificially terraced for farming; facing south. 
supports surrounding dense stands of pine and oak. Surface visibility in 2002 was the same as in 1995; approximately 25 percent.

\section{Levels of Work and Results}

In 1995, Schmidt and

Cruse excavated nine shovel tests and found 2 chert flakes (one with cortex), 2 primary chert flakes, 2 heat-treated decorticate chert flakes, 1 quartzite secondary flake, and 1 piece of firecracked rock (no materials were collected). Schmidt and Cruse (1995) noted that underlying sterile clay was general reached at $70 \mathrm{~cm}$ below the surface. In 2002, CAS-SWT personnel excavated eleven shovel tests and collected 3 exterior flakes and 1 interior flake (Table 4-16). No artifacts were observed on the surface.

\section{Conclusions/Recommendations}

In its current condition, this site appears to have been used as a temporary campsite where limited lithic reduction activities occurred. However, alteration for agricultural purposes has significantly disturbed the site. Although the depth at which artifacts were recovered in 1995 is not stated (Schmidt and Cruse 1995), shovel testing in 2002 revealed only three flakes, all in the upper $20 \mathrm{~cm}$. Therefore, the research value of this siteas a single entity is considered minimal, and we recommend no further testing.
Table 4-16. 41BP435 shovel test results.

\begin{tabular}{|l|l|l|l|l|l|l|l|l|l|l|l|}
\hline 41BP435 & & & & & & & & & & & \\
\hline & & & & & & & & & & & \\
\hline Depth & ST1 & ST2 & ST3 & ST4 & ST5 & ST6 & ST7 & ST8 & ST9 & ST10 & ST11 \\
\hline & & & & & & & & & & & \\
\hline $\mathbf{0 - 1 0}$ & & & & & & & & & & & \\
\hline & & & & & & & & & & & \\
\hline $\mathbf{1 0 - 2 0}$ & & 2 EF & & & & IF & & & & & \\
\hline & clay & & & & & & & & & & \\
\hline $\mathbf{2 0 - 3 0}$ & & & & & & & & & & & \\
\hline & & & & & clay & & & & & clay & \\
\hline $\mathbf{3 0 - 4 0}$ & & & & & & & & & & & \\
\hline & & clay & & & & & water & & & & \\
\hline $\mathbf{4 0 - 5 0}$ & & & & & & EF & & & & & \\
\hline & & & clay & clay & & & & clay & clay & & clay \\
\hline $\mathbf{5 0 - 6 0}$ & & & & & & & & & & & \\
\hline & & & & & & water & & & & & \\
\hline $\mathbf{6 0 - 7 0}$ & & & & & & & & & & & \\
\hline & & & & & & & & & & & \\
\hline $\mathbf{7 0 - 8 0}$ & & & & & & & & & & & \\
\hline & & & & & & & & & & & \\
\hline & Key: EF-Exterior Flake; IF-Interior Flake & & & \\
\hline
\end{tabular}

\section{BP436}

\section{Description}

41BP436 (Figures 4-33 and 4-34) is a prehistoric open campsite with burned rock and an associated lithic scatter. The approximate site size is $2,091 \mathrm{~m}^{2}$ and it is located $115 \mathrm{~m}$ north of McLaughlin Creek. Ranging in elevation from 480-490 feet, the site is situated on a sideslope in a small opening, with Axtell fine sandy loam (AfC2) supporting moderately dense stands of pine, cedar, and tall grasses. Surface visibility in 2002 was approximately 10 percent.

\section{Levels of Work and Results}

When Schmidt and Cruse initially recorded 


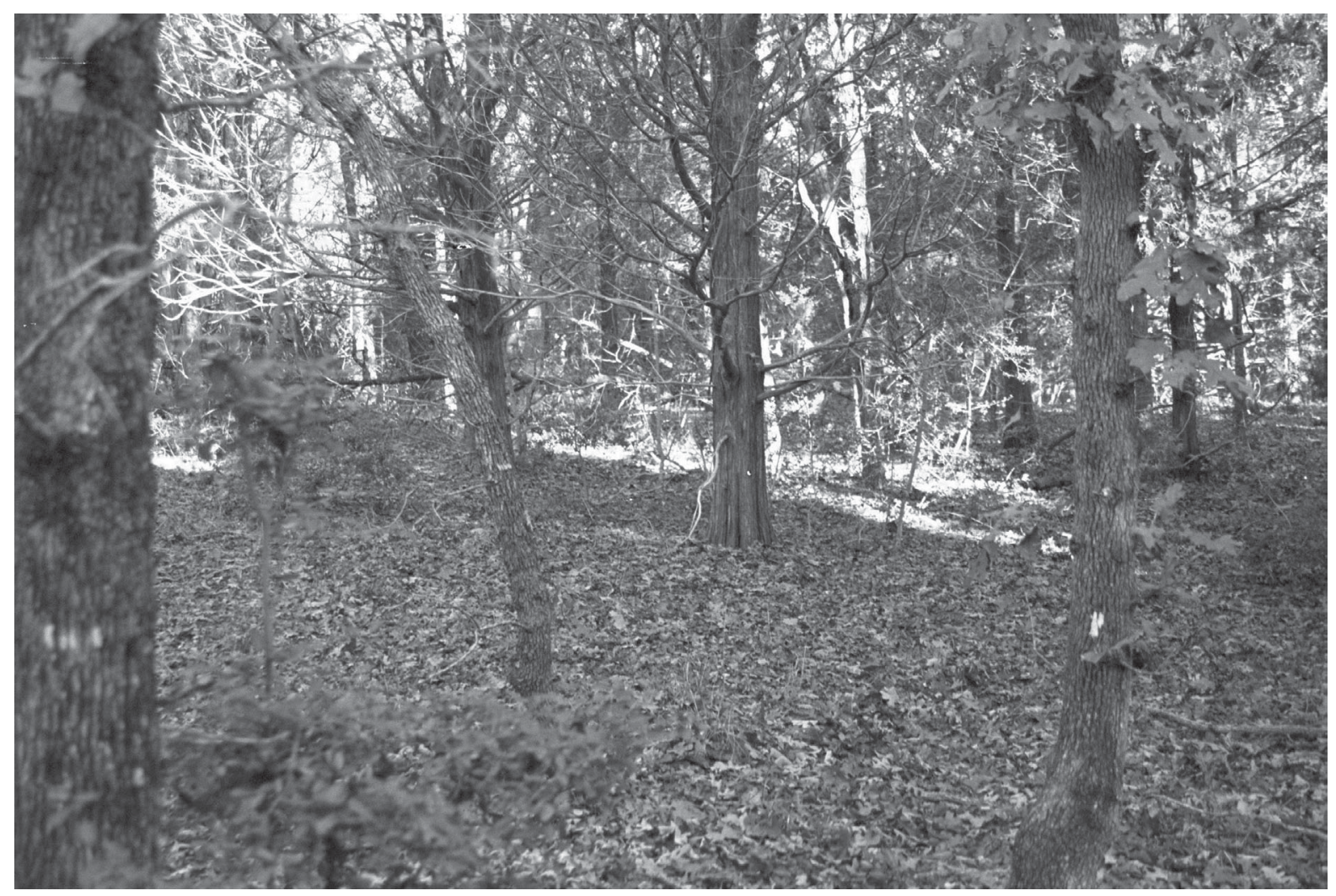

Figure 4-33. 41BP436 sets on a wooded sideslope; facing east.

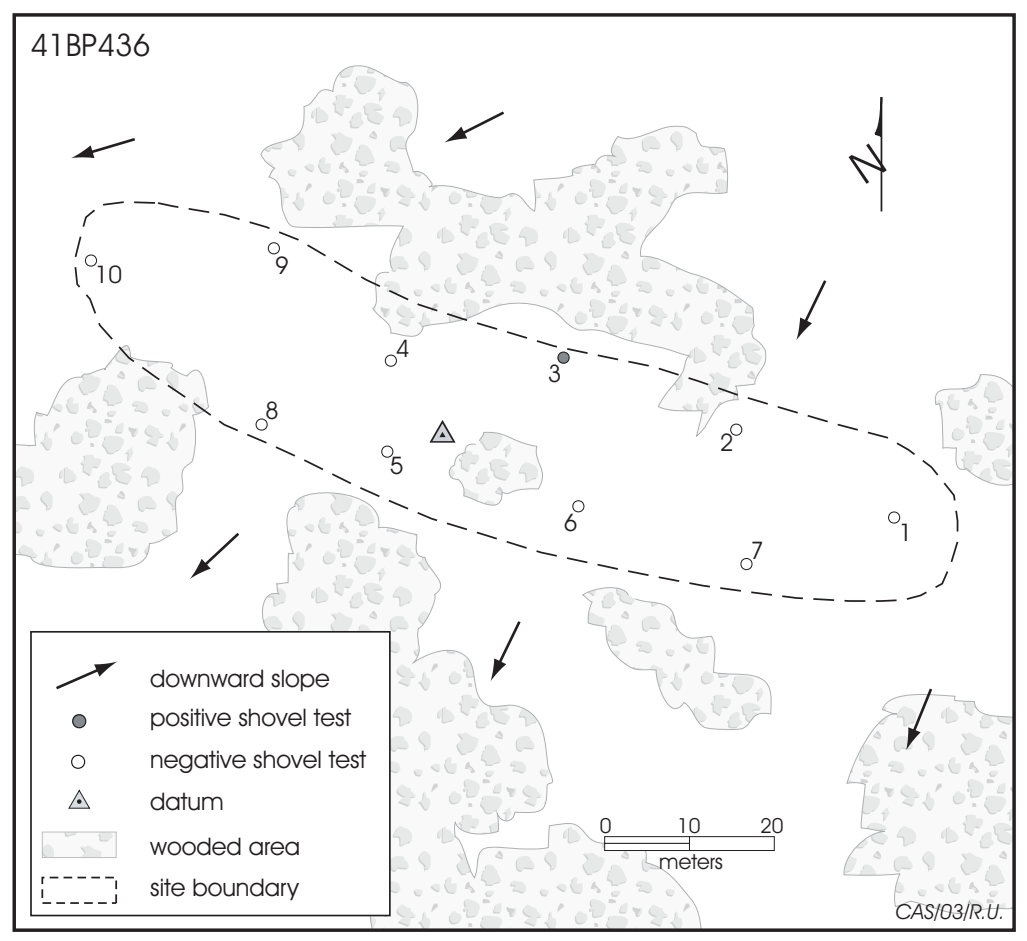

this site in 1995, they did not comment on whether or not artifacts were visible on the surface. At that time they dug ten shovel tests, and although the depths of recovery are not published (1995), they found a total of 5 chert flakes, 3 quartzite firecracked rocks, and several pieces of charcoal. They noted that clay was encountered between 70 and 80 $\mathrm{cm}$ below the surface. In 2002, CAS-SWT personnel excavated an additional ten shovel tests and collected only 1 piece of firecracked rock and 1 exterior flake (Table 4-17). No cultural material was observed on the surface in 2002.

Figure4-34. Site map,41BP436. 
Table 4-17. 41BP436 shovel test results.

\begin{tabular}{|c|c|c|c|c|c|c|c|c|c|c|}
\hline \multicolumn{11}{|l|}{ 41BP436 } \\
\hline Depth $(\mathrm{cm})$ & ST1 & ST2 & ST3 & ST4 & ST5 & ST6 & ST7 & ST8 & ST9 & ST10 \\
\hline \multicolumn{11}{|l|}{$0-10$} \\
\hline & & & & & & & & & & clay \\
\hline \multicolumn{11}{|l|}{$10-20$} \\
\hline & & & & & & & & & clay & \\
\hline $20-30$ & & & fcr & & & & & & & \\
\hline \multirow[t]{2}{*}{$30-40$} & & & EF & & & & & & & \\
\hline & & & & clay & & & & & & \\
\hline \multicolumn{11}{|l|}{$40-50$} \\
\hline \multicolumn{11}{|l|}{$50-60$} \\
\hline \multicolumn{11}{|l|}{$60-70$} \\
\hline & & & clay & & & & & & & \\
\hline \multicolumn{11}{|l|}{$70-80$} \\
\hline & & & & & clay & & & clay & & \\
\hline \multicolumn{11}{|l|}{$80-90$} \\
\hline & clay & & & & & & water & & & \\
\hline \multicolumn{11}{|l|}{$90-100$} \\
\hline & & clay & & & & sand & & & & \\
\hline \multicolumn{11}{|l|}{$100-110$} \\
\hline \multicolumn{11}{|l|}{$110-120$} \\
\hline & Key: & EF-E & xteric & or Fla & $k e \cdot f$ & $r$-fire & rackeo & rock & $<<1 "$ & \\
\hline
\end{tabular}

National Register of Historic Places, and no further testing is recommended.

\section{BP471}

\section{Description}

41BP471 (Figures 4-35 and 4-36) is a prehistoric open campsite with firecracked rock and lithic debitage. It covers an area of approximately $25,693 \mathrm{~m}^{2}$, and ranges in elevation from 440 to 450 feet. Situated on an open sideslope below a rounded knoll, Patilo complex soils ( $\mathrm{PaE}$ ) support the growth of tall grasses and scattered prickly pear. The site lies approximately $15 \mathrm{~m}$ west of Wine Cellar Road. It is bordered on the west by an intermittent drainage, and a constantly flowing spring-fed drainage is $60 \mathrm{~m}$ to the south (Figure 4-36). Road construction has disturbed the eastern portion of the site, a fence post was found, and infrequent tire ruts were observed on its lower, southern portion. Surface visibility was approximately 10 percent in both May 1996 and November 2002.
Conclusions/

\section{Recommendations}

In its current condition, this site appears to have been used as a small temporary campsite where limited lithic reduction activities occurred. However, an examination of shovel testing results (Table 4-17) provides little evidence that intact features and/or other cultural material may be present below the surface. As such, we assess the ability of this site to provide further significant information to the prehistory of the region as minimal; it is not eligible for nomination to the

\section{Levels of Work and Results}

This site was initially recorded and tested by Sullo and Wormser in 1996. According to their site report, 4 of their 13 shovel tests were positive and they recovered 10 flakes. In 2002, CAS-SWT personnel excavated 26 shovel tests and collected 9 large (>1") pieces of firecracked rock, 17 smaller $(<1 ")$ pieces of firecracked rock, 2 pieces of lithic shatter, 4 exterior flakes, 28 interior flakes, 1 piece of miscellaneous metal, 1 piece of charcoal, 1 hammerstone, 1 bullet, and 2 utilized flakes (Table 


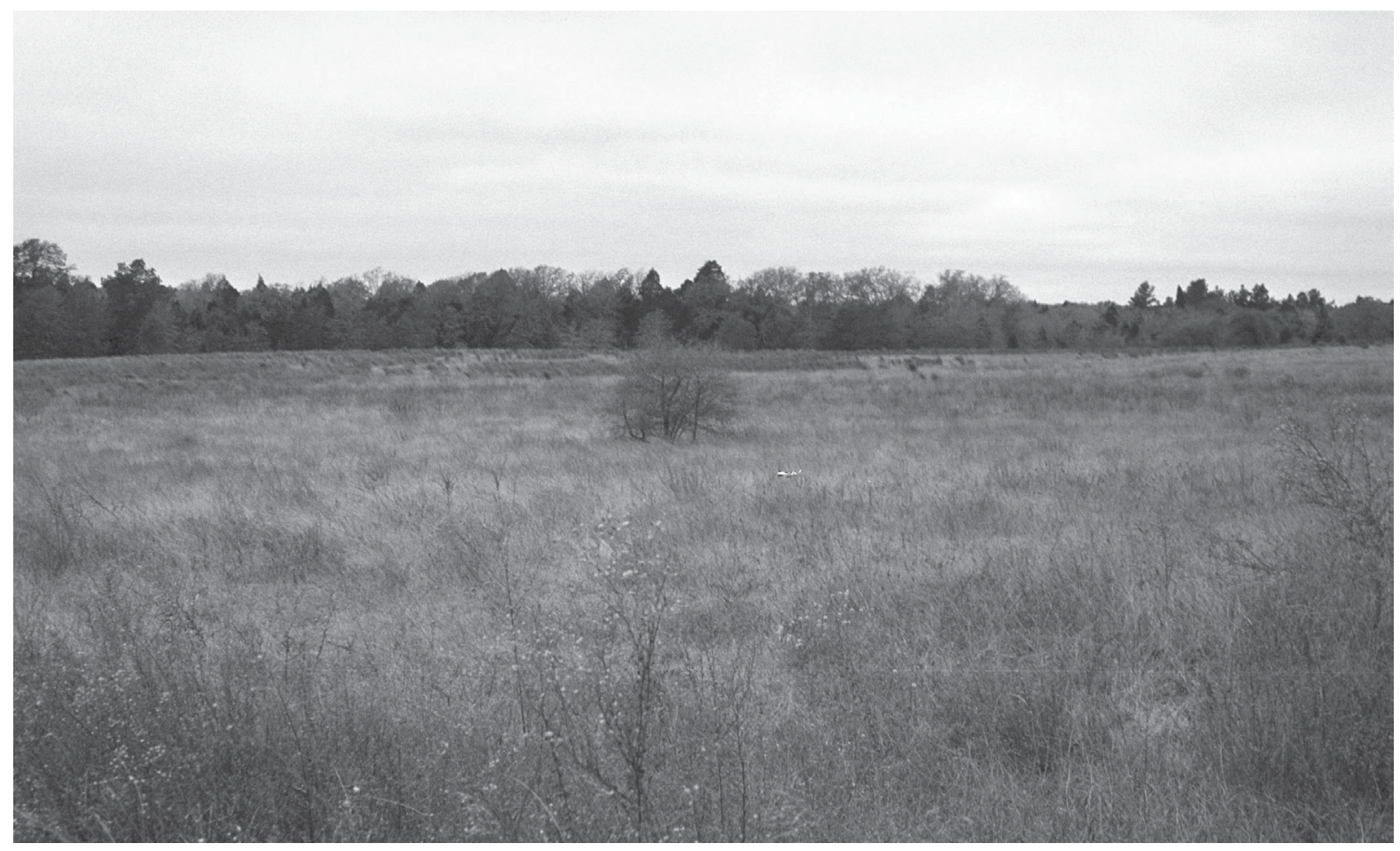

Figure 4-35. 41BP471 is a large, deeply buried open campsite located on a ridge and footslope; facing west.

4-18). Sullo and Wormser made no mention of surface artifacts being present, and in 2002, CAS archaeologists did not observe any surface artifacts.

\section{Conclusions/Recommendations}

In its current condition, this site appears to have been used extensively as a prehistoric open campsite. Twenty-one of the twenty-six shovel tests were positive, with some cultural deposits as deep as $130 \mathrm{~cm}$ below the surface. Although the recovery of a bullet between 50 and $60 \mathrm{~cm}$ in Shovel Test 18, and a piece of metal between 20-30 cmin Shovel Test 5 is troubling, subjectively, the site appears to be 70 percent intact, with minimal disturbance as noted above.

FIGURE 4-36. REDACTED

Figure4-36. Site map,41BP471. 
Table 4-18. 41BP471 shovel test results.

\begin{tabular}{|c|c|c|c|c|c|c|c|c|c|c|c|c|c|c|}
\hline \multicolumn{15}{|l|}{ 41BP471 } \\
\hline Depth $(\mathrm{cm})$ & $\underline{\text { ST1 }}$ & $\underline{\text { ST2 }}$ & $\underline{\mathrm{ST} 3}$ & $\underline{\text { ST4 }}$ & $\underline{\text { ST5 }}$ & $\underline{\text { ST6 }}$ & $\underline{\mathrm{ST7}}$ & $\underline{\mathrm{ST} 8}$ & ST9 & ST10 & ST11 & ST12 & ST13 & $\underline{\text { ST14 }}$ \\
\hline & & & & & & & & & & & & & & \\
\hline $0-10$ & & & IF & & & IF & & & & $\mathrm{IF}$ & IF & & & \\
\hline & & & & & & & & & & & & & & \\
\hline $10-20$ & & $2 \mathrm{IF}$ & & & & & & & & & IF & & & \\
\hline & & & & & & & & & & & & & & \\
\hline $20-30$ & & & & IF & M & & fcr & $\mathrm{Ch}$ & & & & IF & & \\
\hline & & & & & & & & & & & & & & \\
\hline $30-40$ & & $3 \mathrm{IF}$ & UF & FCR & & & IF/FCR & & & & & & & \\
\hline & & & & & & & & & & & & & & \\
\hline $40-50$ & & & & & & & & & & & & & IF & \\
\hline & & & clay & & & clay & & & & & & & & \\
\hline $50-60$ & & $\mathrm{EF}$ & & & $\mathrm{S}$ & & . & & & & & & $E F / I F$ & \\
\hline & & & & & & & & & & & & & & \\
\hline $60-70$ & fcr & & & & & & & fcr & & & & & & \\
\hline & & & & & & & & & & & & & & \\
\hline $70-80$ & $\mathrm{~s}$ & & & IF & $2 \mathrm{FCR} / \mathrm{fcr}$ & & & & & & fcr & & & fcr \\
\hline & & & & & & & & & & & & & & \\
\hline $80-90$ & & & & $2 \mathrm{IF} / \mathrm{fcr}$ & fcr & & $\mathrm{EF}$ & & & & & & & \\
\hline & & & & & & & & & & & & & & \\
\hline $90-100$ & $\mathrm{EF} / 2 \mathrm{FCR}$ & & & $2 \mathrm{IF}$ & & & & $\mathrm{H}$ & & & fcr & & & \\
\hline & & & & & & & sand & & sand & sand & & sand & sand & sand \\
\hline $100-110$ & & & & & $\mathrm{fcr} / \mathrm{FCR}$ & & & & & & & & & \\
\hline & & sand & & clay & & & & & & & sand & & & \\
\hline $110-120$ & & & & & & & & & & & & & & \\
\hline & sand & & & & sand & & & sand & & & & & & \\
\hline $120-130$ & & & & & & & & & & & & & & \\
\hline & & & & & & & & & & & & & & \\
\hline
\end{tabular}

Larger pieces of firecracked rock encountered between $30-40 \mathrm{~cm}, 60-80 \mathrm{~cm}$, and $90-110 \mathrm{~cm}$ in selected shovel tests suggests that there are discrete areas in the site that have a high potential for possibly intact cultural features buried deep below the surface. Such features have the potential to yield significant information about the paleoenvironment, and site formation processes, and can infer past subsistence and mobility patterns when applied to theoretical models. Therefore, the research value of this site as a single entity is considered high. We recommend five backhoe trenches be excavated in the areas of Shovel Tests 1,4 and $5 ; 7-8 ; 11 ; 15-16$, and 26 . Should potentially intact features be encountered during trenching operations, 1x1-m units should be excavated to further evaluate the overall significance of the site. 
Table4-18. (Continued)

\begin{tabular}{|c|c|c|c|c|c|c|c|c|c|c|c|c|}
\hline 41BP471 & & & & & & & & & & & & \\
\hline Depth (cm) & ST15 & ST16 & ST17 & ST18 & ST19 & ST20 & ST21 & ST22 & ST23 & ST24 & ST25 & ST26 \\
\hline $0-10$ & & & & & fcr & & & & & & & \\
\hline $10-20$ & & & & & & & & & & & & \\
\hline $20-30$ & & IF & UF & & & & & & & & & \\
\hline $30-40$ & & & & & & & & & & IF & & \\
\hline $40-50$ & fcr & & & $\mathrm{Bu} / \mathrm{EF}$ & & & & & & & & \\
\hline $50-60$ & & & & & & & & & & & & \\
\hline $60-70$ & $\mathrm{fcr} / \mathrm{FCR}$ & & & fcr & & & & IF & & & & \\
\hline & & & & & & & & & & & clay & \\
\hline $70-80$ & & & & & & & & IF & & & & \\
\hline & & & & & & & & & & clay & & \\
\hline $80-90$ & fcr & & & & & & & IF & & & & \\
\hline $90-100$ & & fcr & & & & & & & & & & IF \\
\hline & sand & & sand & sand & sand & sand & & sand & sand & & & \\
\hline $100-110$ & & IF & & & & & & & & & & FCR \\
\hline & & sand & & & & & sand & & & & & \\
\hline $110-120$ & & & & & & & & & & & & IF \\
\hline & & & & & & & & & & & & \\
\hline $120-130$ & & & & & & & & & & & & $\mathrm{fcr}$ \\
\hline & & & & & & & & & & & & clay \\
\hline $\begin{array}{l}\text { Key: fcr-Firec } \\
\text { 3u-Bullet: EF- }\end{array}$ & 20 & $<1 " ;$ & & $\mathrm{cla}$ & & & & & ke; & E-Util & $d F$ & \\
\hline
\end{tabular}

\section{BP477}

\section{Description}

41BP477 (Figures 4-37 and 4-38) is a prehistoric open campsite with firecracked rock, at least one hearth feature, a Scallorn projectile point, and an associated lithic scatter. Covering approximately $4,451 \mathrm{~m}^{2}$, it is situated on an open field footslope that gently slopes to the southeast toward the confluence of Spring Branch and an intermittent drainages. Patillo complex soils (PaE) support the growth of tall grasses and a surrounding treeline that consists of oak and cedar. A row of fence posts bisects the western portion of the site running northwest-southeast. There is also a heavily eroded area of exposed clay in the upper, northeastern 


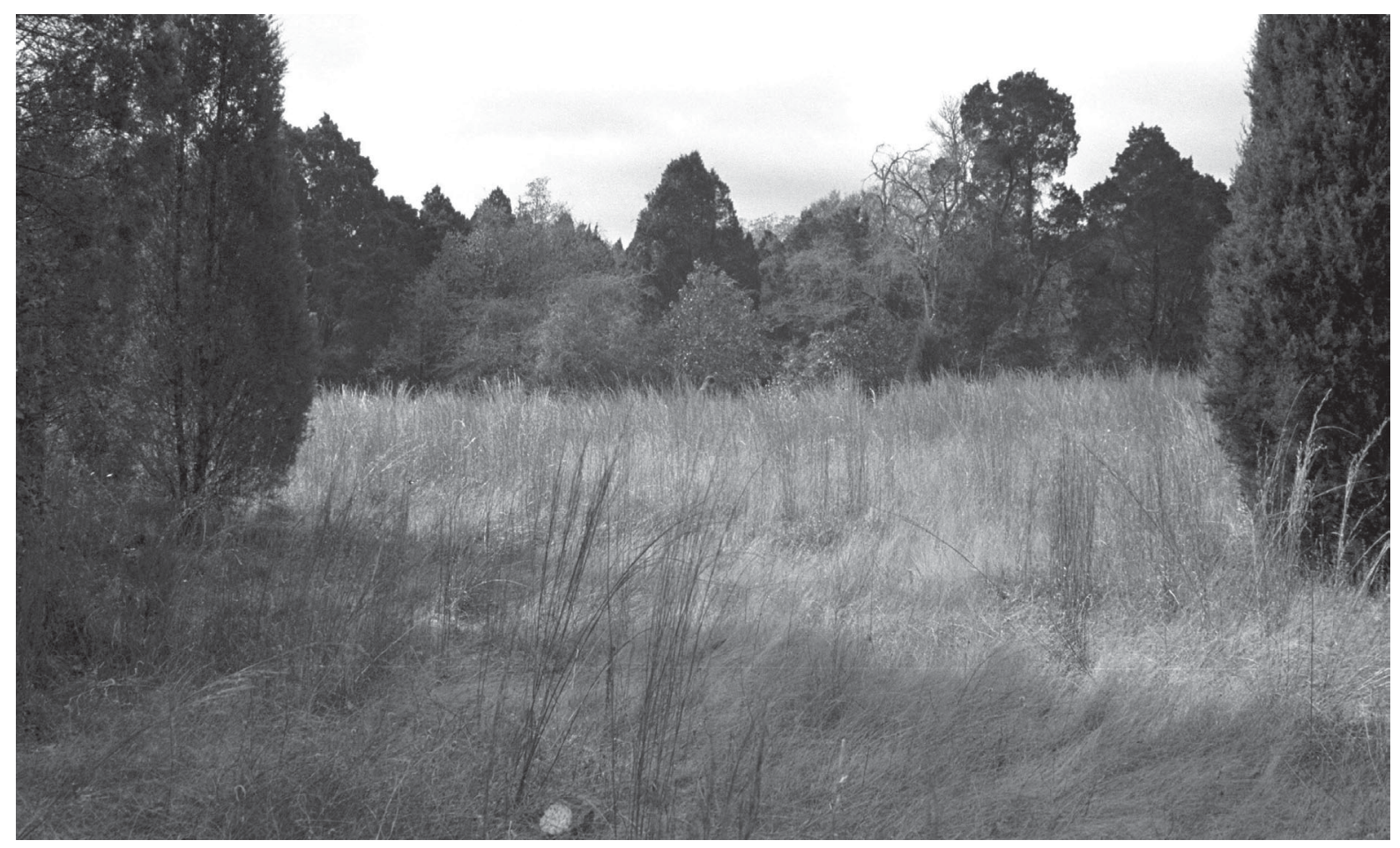

Figure 4-37. 41BP477 is a buried open campsite located on a ridge and footslope above an intermittent tributary of Big Sandy Creek; facing southwest.

portion just beyond the site boundary, and Robinson et al. noted vehicle tracks on the surface in 1996. Surface visibility was less than 5 percent in the winter of 2002.

\section{Levels of Work and Results}

Initial testing of this site was conducted by Robinson et al. in 1996. They dug 14 shovel tests and recovered 29 chert flakes, 55 pieces of burned rock, 1 bison tooth, and 1 Scallorn arrow point. In addition, they collected a thin chert biface from the surface. In 2002, CAS-SWT personnel excavated 18 shovel tests and collected 65 large $(>1 ")$ pieces of firecracked rock, 44 smaller (<1")

FIGURE 4-38. REDACTED

Figure4-38. Site map, 41BP477. 
FIGURE 4-39. REDACTED

Figure 4-39. Overlay of the 1996 and 2002 site maps.

pieces of firecracked rock, 4 exterior flakes, 13 interior flakes, 5 utilized flakes, 1 bullet, and 1 retouched flake (Table 4-19). Two hearths encountered between 50-60 $\mathrm{cm}$ below the surface in Shovel Tests 2 and 16 accounted for 55 of the firecracked rock pieces collected. No artifacts were observed on the surface in 2002.

Because the results of the 1996 project are published (Meissner 2001:49), we are able to compare the results of the 1996 testing with those of 2002 by $20-\mathrm{cm}$ levels (Table $4-19$ ). Using the positioning of fence posts as references, Figure 439 provides an overlay of the 1996 and 2002 site maps.

\section{Conclusions/Recommendations}

Although a diagnostic Scallorn point recovered between 20-40 cm suggests an Austin phase, Late Prehistoric occupation, a modern bullet casing recovered between $20-30 \mathrm{~cm}$ in the general area is problematic. Nevertheless, the results of shovel testing provide evidence for potentially undisturbed cultural deposits well below $40 \mathrm{~cm}$. Two hearths 
Table 4-19.41BP477 combined 1996 and 2002 shovel test results. 1996 ST data in this table are placed relative to their proximity to the 2002 STs (see Figure 4-39).

\begin{tabular}{|c|c|c|c|c|c|c|c|c|c|c|c|c|}
\hline \multicolumn{13}{|l|}{ 41BP477 } \\
\hline & 2002 & 1996 & 2002 & 1996 & 2002 & 1996 & 2002 & 1996 & 2002 & 1996 & 2002 & 1996 \\
\hline Depth $(\mathrm{cm})$ & ST1 & (st9) & $\underline{\text { ST2 }}$ & (st6) & ST3 & (st5) & ST4 & (st4) & $\underline{\text { ST5 }}$ & (st3) & ST6 & (st1) \\
\hline \multirow[t]{2}{*}{$0-10$} & & & & & & & IF & & & & $\mathrm{fcr}$ & \\
\hline & & & & & & $2 \mathrm{~F} / \mathrm{S}$ & & 3FCR & & & & B \\
\hline $10-20$ & & & fcr & & & & & & 2IF/FCR & & $2 \mathrm{fcr}$ & \\
\hline \multirow[t]{2}{*}{$20-30$} & fcr & & & & & & $\mathrm{fcr}$ & & IF/FCR & & & \\
\hline & & & & $\mathrm{F}$ & & $2 \mathrm{FCR}$ & & $4 \mathrm{FCR} / \mathrm{f}$ & & FCR & & \\
\hline $30-40$ & & & fcr & & IF/FCR & & & & fcr & & & \\
\hline \multirow[t]{2}{*}{$40-50$} & EF & & & & IF & & & & $\mathrm{UF} / \mathrm{EF} / 2 \mathrm{fcr} / 2 \mathrm{FCR}$ & & & \\
\hline & & 7FCR/F & & & & & & & & spall & & \\
\hline \multirow[t]{2}{*}{$50-60$} & & & $6 \mathrm{FCR} / \mathrm{fcr}$ & & fcr & & FCR & & $\mathrm{IF} / \mathrm{fcr}$ & & & \\
\hline & & & Hearth & & & & & & & & & \\
\hline \multirow[t]{2}{*}{$60-70$} & & & $\mathrm{fcr} / \mathrm{FCR}$ & & FCR & & & & $\mathrm{IF} / 2 \mathrm{fcr} / 5 \mathrm{FCR}$ & & FCR & \\
\hline & clay & & & $\mathrm{FCR} / \mathrm{F}$ & & & & $\mathrm{F}$ & & $6 \mathrm{FCR}$ & & Ch \\
\hline $70-80$ & & & $2 \mathrm{FCR} / 2 \mathrm{fcr}$ & & UF/IF & & & & & & & \\
\hline & & & & & & & & & & & & \\
\hline \multicolumn{13}{|l|}{$80-90$} \\
\hline & & & & $\mathrm{F}$ & & & & & water & $3 \mathrm{FCR}$ & & \\
\hline \multirow[t]{2}{*}{$90-100$} & & & & & EF/fcr/2FCR & & IF & & & & & \\
\hline & & & sand & & & & & & & & sand & \\
\hline \multirow[t]{2}{*}{$100-110$} & & & & & & & FCR & & & & & \\
\hline & & & & FCR & sand & & & & & $\mathrm{FCR} / \mathrm{f}$ & & \\
\hline \multirow[t]{2}{*}{$110-120$} & & & & & & & & & & & & \\
\hline & & & & & & & sand & & & & & \\
\hline \multicolumn{13}{|l|}{$120-130$} \\
\hline & & & & & & & 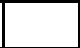 & & & & 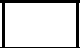 & \\
\hline
\end{tabular}

Note: FCR size not avaliable for the 1996 project.

Table 4-20. Synthesis of 1996 and 2002 shovel test results.

\begin{tabular}{|c|c|c|c|l|}
\hline Depth & $\begin{array}{c}\# \\
\text { Levels }\end{array}$ & $\begin{array}{c}\# \\
\text { FCR/Level }\end{array}$ & $\begin{array}{c}\# \\
\text { Flakes/Level }\end{array}$ & Other \\
\hline $0-20 \mathrm{~cm}$ & 63 & .13 & .11 & Biface \\
\hline $20-40 \mathrm{~cm}$ & 61 & .39 & .15 & Scallorn/Core/Tested cobble \\
\hline $40-60 \mathrm{~cm}$ & 56 & $.41^{*}$ & .16 & 2 Hearths/Bison tooth \\
\hline $60-80 \mathrm{~cm}$ & 47 & .68 & .15 & Charcoal \\
\hline $80-100 \mathrm{~cm}$ & 38 & .37 & .34 & \\
\hline $100-120 \mathrm{~cm}$ & 19 & .26 & .05 & Charcoal \\
\hline
\end{tabular}

* Hearth rocks not included in computation. 
Table 4-19. (Continued)

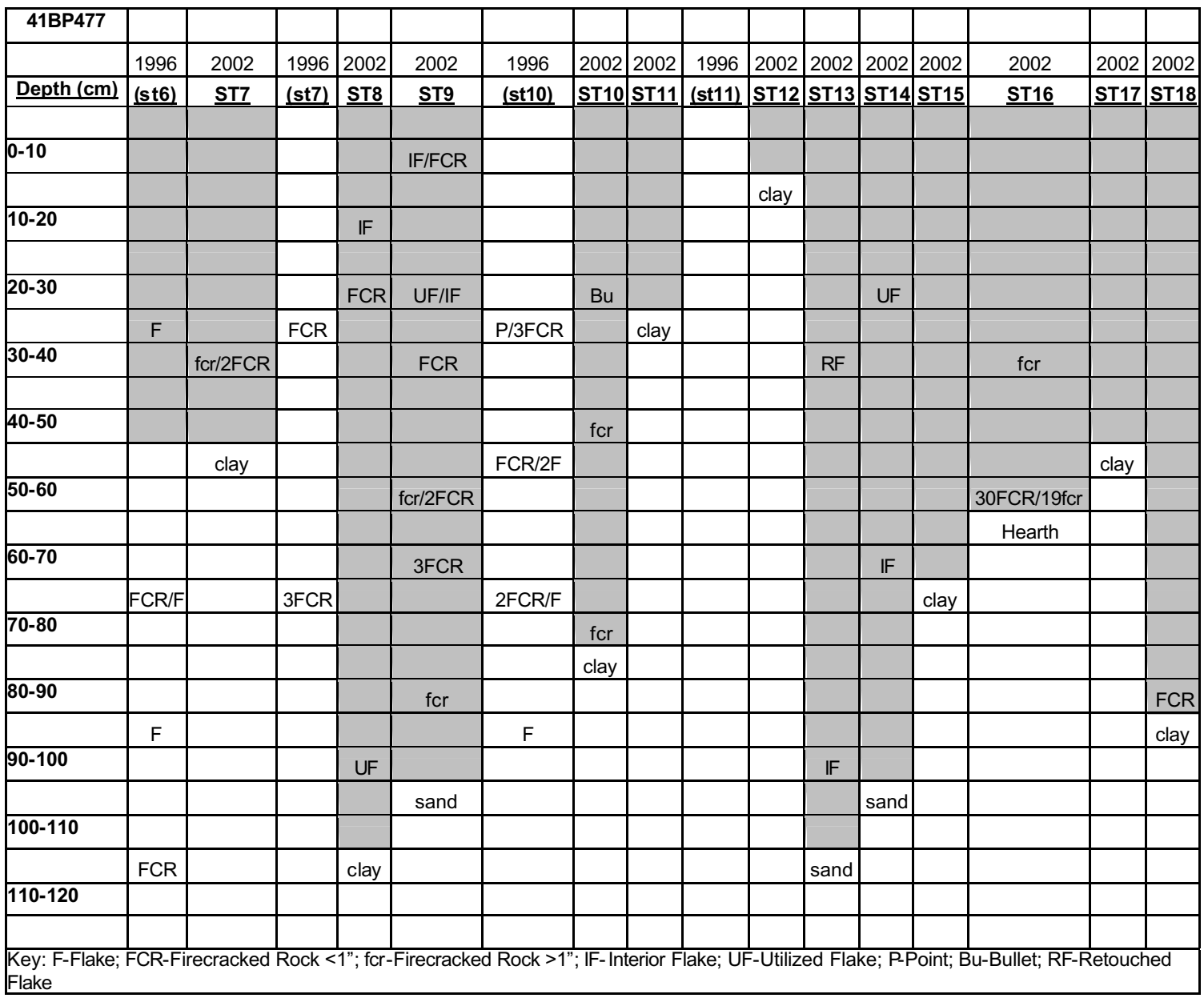

were encountered between 50-60 $\mathrm{cm}$ during the 2002 testing project, and additional data from shovel testing indicates there is a very high probability for finding other buried and possibly intact firecracked rock hearth features with further testing. Peaks in both FCR/level and fIakes/level occur between $60-100 \mathrm{~cm}$ below the surface. The vertical continuum of cultural material across the site to at least $120 \mathrm{~cm}$ below the surface suggests that a significant amount (subjectively 85\%) of this site still remains intact. In addition, a bison tooth and two charcoal samples recovered in deeply buried contexts suggests the potential for preservation of charcoal, faunal, and ethnobotanical remains may be good.
In sum, the research value of this site is considered high. The results of systematic shovel testing provided evidence of possibly intact cultural deposits buried deep below the surface. Such deposits have the potential to yield significant information about the paleoenvironment, site formation processes, and can infer past subsistence and mobility patterns when applied to theoretical models. Therefore, in order to further evaluate the potential of this site we recommend excavating one $1 \times 1-m$ each in the immediate areas of Shovel Tests 2 and 16 to evaluate the integrity of the hearth features encountered there; and, four backhoe trenches in the areas near Shovel Tests 3, 5, 6 and 9, and near the creek between Shovel Tests 6 and 
16. Should potentially intact features be encountered during trenching operations, additional $1 \times 1-m$ units should be excavated to further evaluate the overall significance of the site.

\section{BP491}

\section{Description}

41BP491 (Figure 4-40 and 4-41) is a prehistoric open campsite with firecracked rock and associated lithic debitage. The site covers approximately $4,382 \mathrm{~m}^{2}$, and the nearest natural water source is an intermittent tributary of Big Sandy Creek, $65 \mathrm{~m}$ to the northeast. Located in an upland setting in a generally wooded area, Silstid loamy fine sand ( $\mathrm{SkC})$ supports generally dense stands of oak and cedar. 41BP495, a multi-component prehistoric open campsite, lies approximately 30 meters to the southeast (Nickels and Lehman 2003). Surface visibility during visits in 1996 and 2002 was 5-10 percent.

\section{Levels of Effortand Results}

When this site was initially recorded by Robinson et al. in 1997, they dug three shovel tests, recovering 2 pieces of burned rock between $0-20 \mathrm{~cm}, 3$ pieces of burned rock between $60-80 \mathrm{~cm}, 1$ flake between $40-60 \mathrm{~cm}$, and 2 flakes between $80-100$ cm. In 2002, CAS-SWT personnel excavated 23 shovel tests and found 4 large (>1") pieces of firecracked rock, 11 smaller ( $<1 ")$ pieces of firecracked rock, 2 pieces of lithic shatter, 14 interior flakes, 1 exterior flake, and 1 retouched flake (Table 4-21). No artifacts or features were ob-

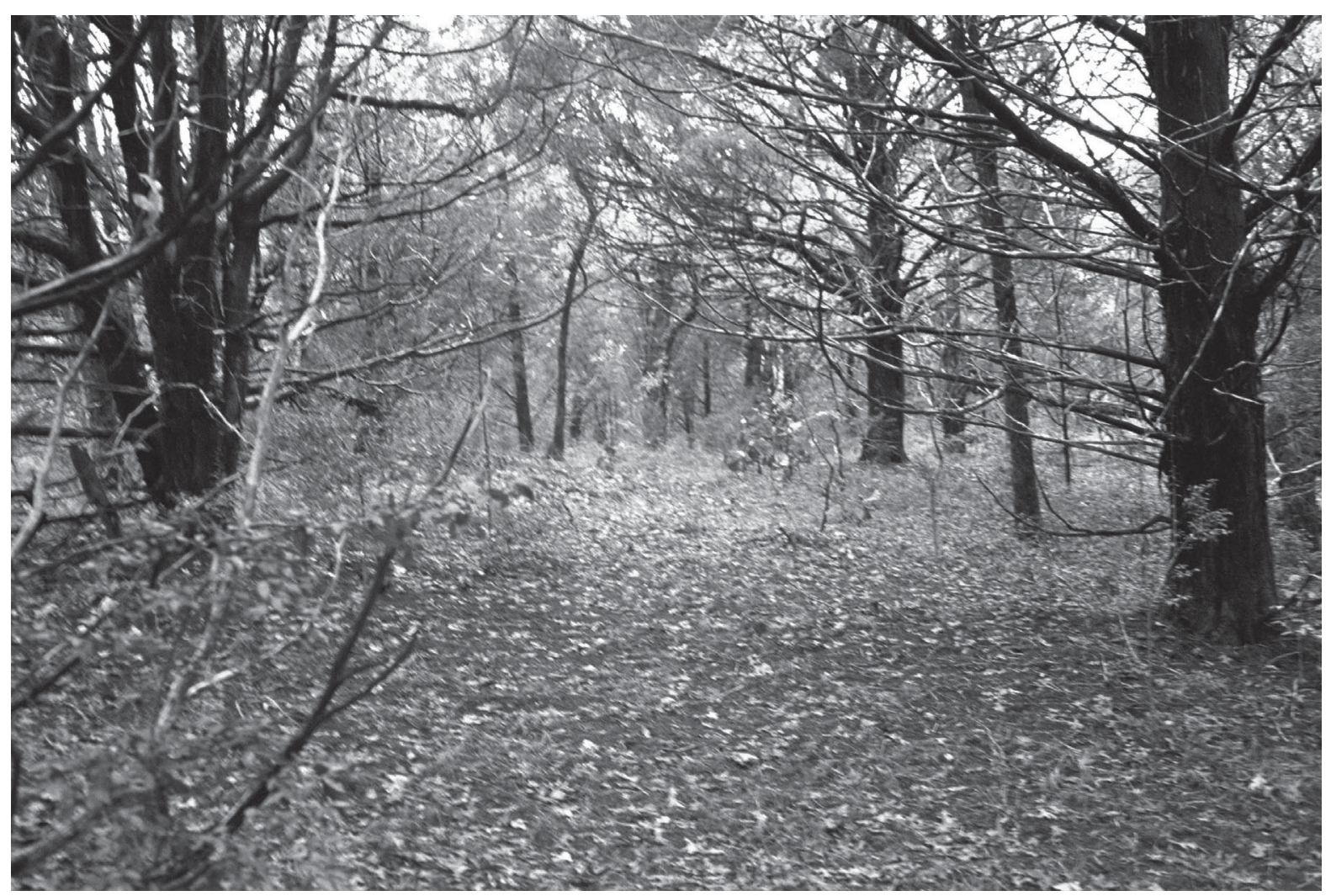

Figure 4-40. 41BP491 lies in a wooded upland setting, adjacent to 41BP495, a multi-component prehistoric open campsite; facing northwest. 


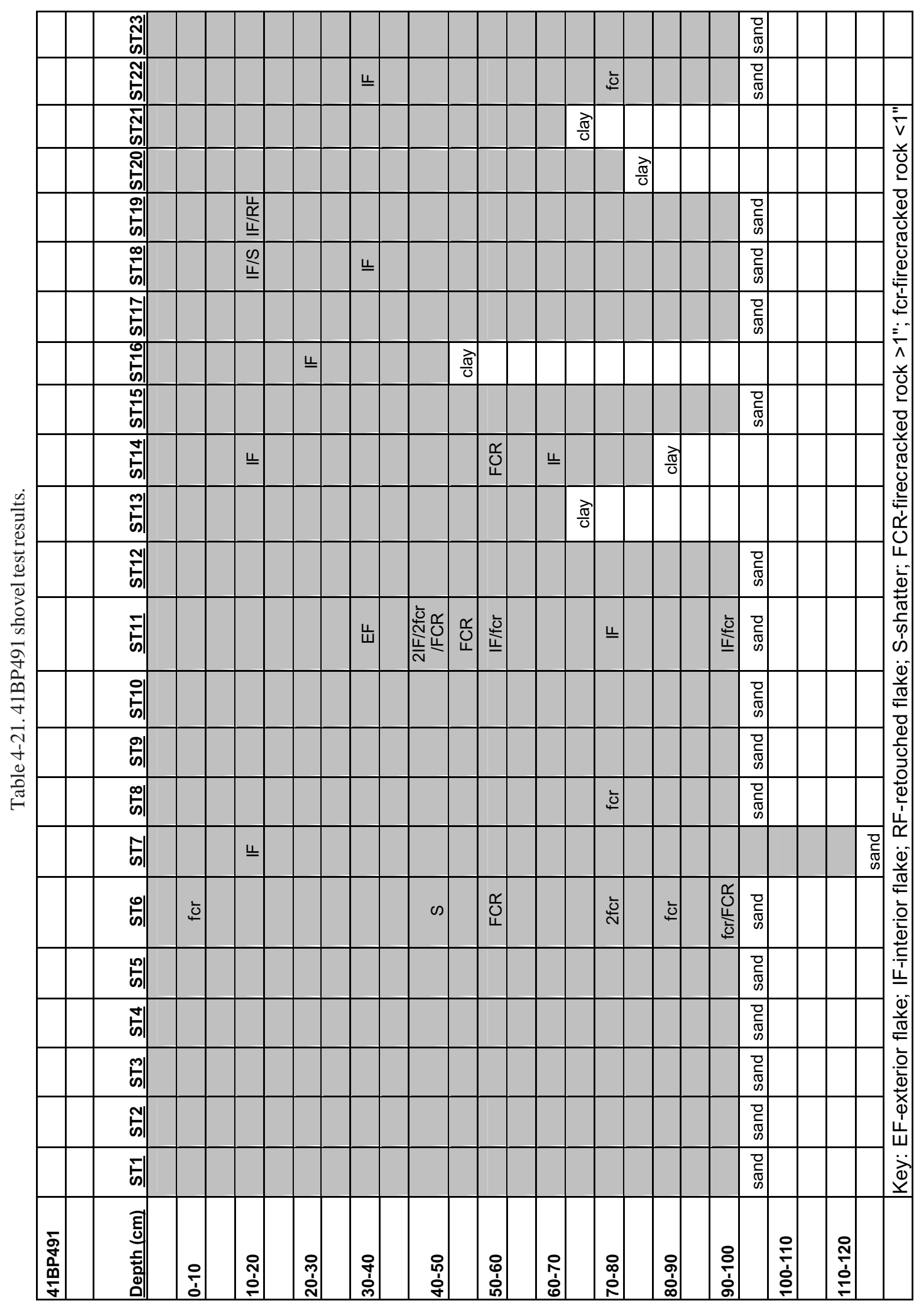




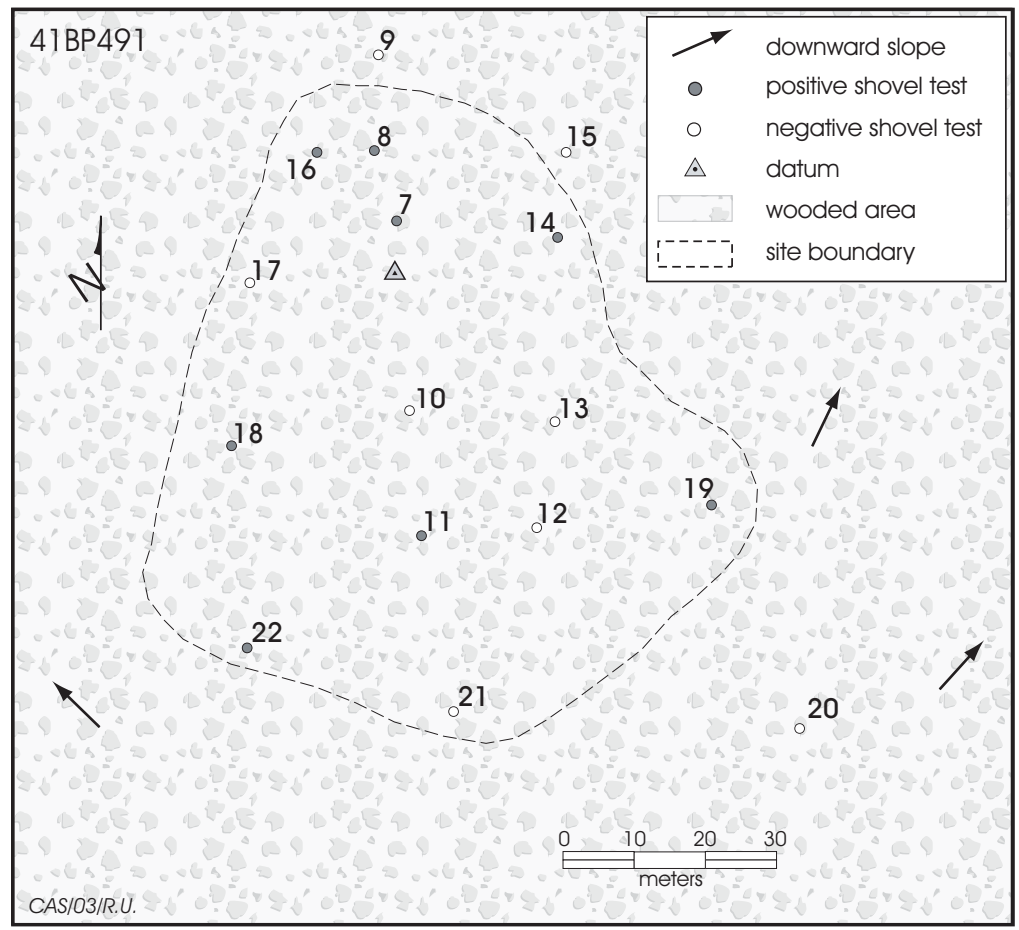

Figure4-41. Site map,41BP491.

served on the surface during either visit to the site. The only disturbances noted were a few rodent burrows and uprooted trees.

\section{Conclusions/Recommendations}

In its current condition, this site appears to have been used as a prehistoric open campsite where lithic reduction activities occurred. Although only 9 of 23 shovel tests were positive, the discrete vertical distribution of artifacts recovered is very similar to that of adjacent site 41BP495. An examination of Table 4-21 suggests an upper component between $40-60 \mathrm{~cm}$, and a lower component between 70-90 cm. At nearby 41BP495, a Late Prehistoric upper component was found between 50-60 cm, and a Late Archaic component between 90-120 cm. 41BP495 also contained numerous firecracked rock hearth features within the upper component (Nickels and Lehman 2003).

Such deposits have the potential to yield significant information about the paleoenvironment and site formation processes, and can infer past subsistence and mobility patterns when applied to theoretical models. Therefore, the research value of this site is considered high. In order to further evaluate its potential, we recommend three backhoe trenches be excavated in the areas near Shovel Tests 6, 11, and 14. Should potentially intact features be encountered during trenching operations, $1 \times 1-m$ units should be excavated to further evaluate the overall significance of the site.

\section{BP528}

\section{Description}

41BP528 (Figures 4-42 and 4-43) is a prehistoric campsite spread across approximately 2,400 $\mathrm{m}^{2}$ of a sideslope overlooking the floodplain of an intermittent drainage, $50 \mathrm{~m}$ to the west. The elevation at the site area ranges from 465-470 feet, and Silstid loamy fine sand ( $\mathrm{SkC})$ supports vegetation that consists of moderately dense stands of oak and cedar. Eroding soils revealed shallow deposits of clay at the northern and southern boundaries of the site, and a fenceline was located on its southern portion (Figure 4-43). Surface visibility in November 2002 was $<10$ percent.

\section{Levels of Effort and Results}

In 1997, Robinson et al. dug one positive shovel test and seven negative shovel probes. They found 1 flake and 1 burned rock between $0-20 \mathrm{~cm}$, and an untypable, but Late Archaic-like dart point fragment and 1 burned rock from between $40-60 \mathrm{~cm}$. In 2002, CAS-SWT personnel excavated 15 shovel tests and collected 2 exterior flakes, 1 interior flake, 4 large pieces of firecracked rock, 1 small piece of 


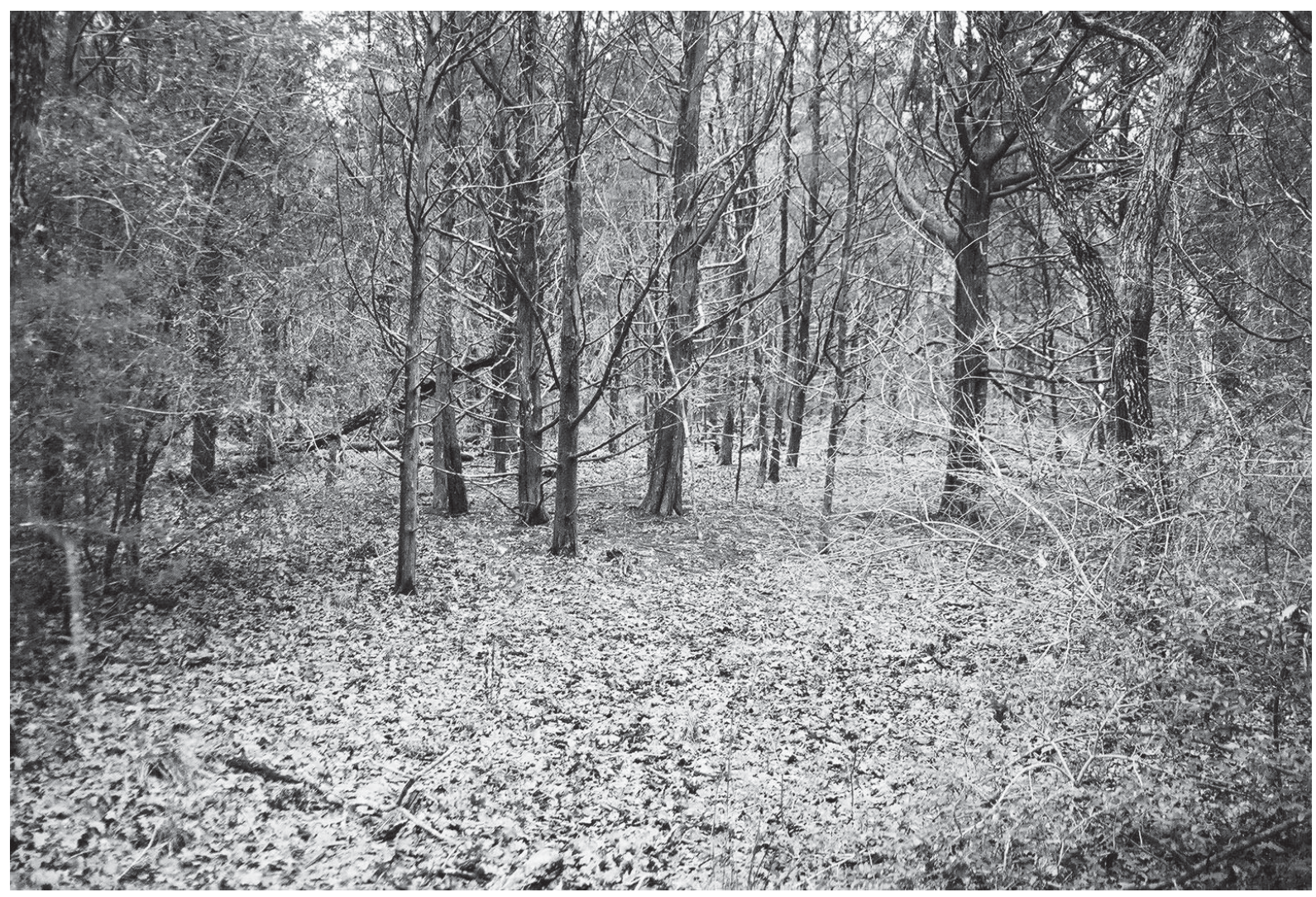

Figure 4-42. 41BP528 is situated on a wooded, gentle sideslope near an intermittent drainage; facing south.

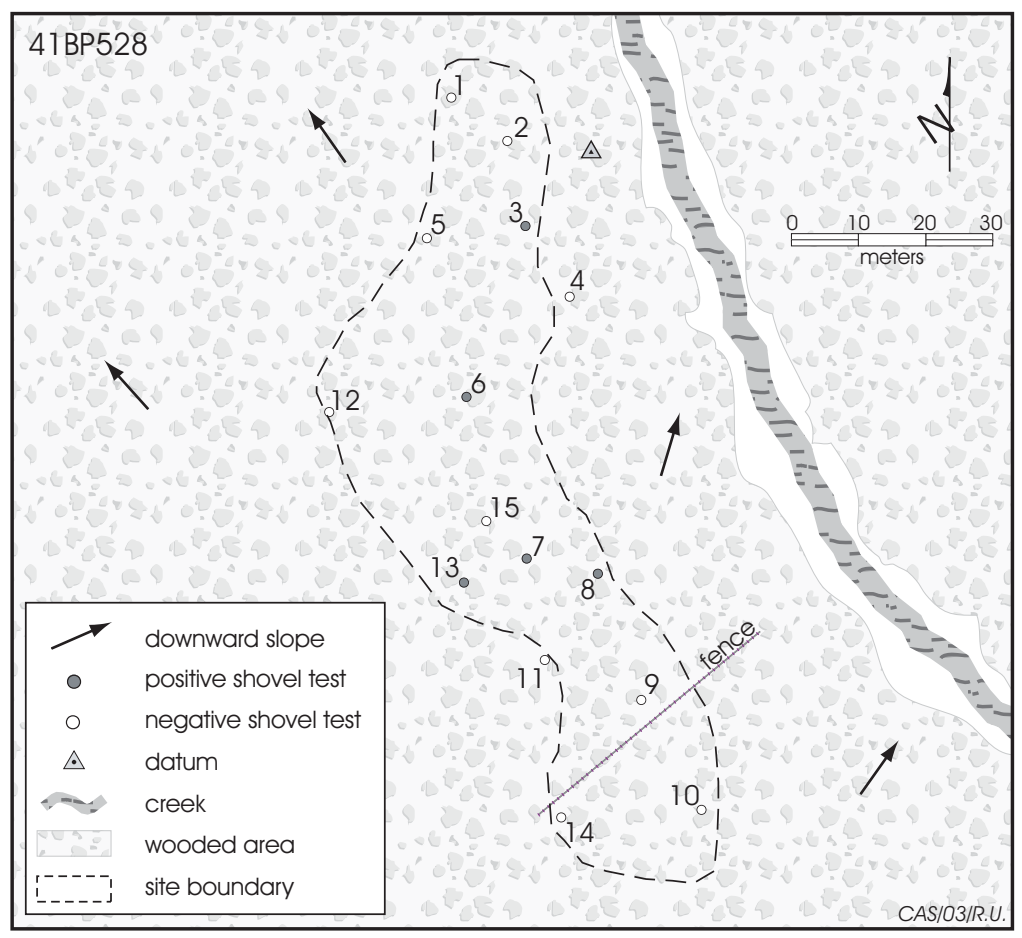

Figure4-43. Site map,41BP528. firecracked rock, and 1 bullet (Table 4-22). No artifacts or features were observed on the surface during either visit.

\section{Conclusions/Recommenda-} tions

In its current condition, this site appears to have been used as a temporary campsite where limited lithic reduction activities occurred. Systematically placed shovel tests revealed deeper sands and cultural deposits in the center of the site. The presence of larger firecracked rock at depths of 10-20 cm (ST 7), 30$40 \mathrm{~cm}$ (ST 6), and 60-70 cm (ST 13) suggests discrete, multiple 
Table 4-22. 41BP528 shovel test results.

\begin{tabular}{|c|c|c|c|c|c|c|c|c|c|c|c|c|c|c|c|}
\hline 41BP528 & & & & & & & & & & & & & & & \\
\hline Depth $(\mathrm{cm})$ & ST1 & ST2 & ST3 & ST4 & ST5 & ST6 & ST7 & ST8 & ST9 & ST10 & ST11 & ST12 & ST13 & ST14 & ST15 \\
\hline & & & & & & & & & & & & & & & \\
\hline \multirow[t]{2}{*}{$0-10$} & & & & & & & $\mathrm{Bu} / \mathrm{fcr}$ & & & & & & & & \\
\hline & & & & & & & & & clay & & & & & & \\
\hline \multirow[t]{2}{*}{$10-20$} & & & $\mathrm{EF}$ & & & & $\mathrm{FCR} / \mathrm{fcr}$ & $E F$ & & & & & & & \\
\hline & clay & clay & & & clay & & & & & clay & & & & clay & \\
\hline \multicolumn{16}{|l|}{$20-30$} \\
\hline & & & clay & clay & & & & & & & & & & & \\
\hline $30-40$ & & & & & & IF/2FCR & & & & & & & & & \\
\hline & & & & & & & & & & & & & & & \\
\hline \multicolumn{16}{|l|}{$40-50$} \\
\hline & & & & & & & clay & clay & & & clay & clay & & & \\
\hline \multirow[t]{2}{*}{$50-60$} & & & & & & & & & & & & & & & clay \\
\hline & & & & & & clay & & & & & & & & & \\
\hline \multirow[t]{2}{*}{$60-70$} & & & & & & & & & & & & & FCR & & \\
\hline & & & & & & & & & & & & & water & & \\
\hline \multicolumn{16}{|l|}{$70-80$} \\
\hline & & & & & & & & & & & & & & & \\
\hline \multicolumn{16}{|l|}{$80-90$} \\
\hline & & & & & & & & & & & & & & & \\
\hline & \multicolumn{13}{|c|}{ Key: EF-Exterior Flake; IF-Interior Flake; UF-Utilized Flake; FCR-firecracked rock >1"; } & & \\
\hline & & fcr-fir & ecrac & ked $\mathrm{r}$ & ock $<1$ & "; Bu-bull & & & & & & & & & \\
\hline
\end{tabular}

occupations, with possibly intact hearth features. A dart point recovered between $40-60 \mathrm{~cm}$ suggests a possible Late Archaic occupation at that depth.

In sum, the results of shovel testing indicate this site may contain multiple components, with a middle component dating to the Late Archaic. However, the site is small, and generally shallow except in discrete areas. Thus the research value of this site is considered moderate. We recommend three backhoe trenches be placed in the immediate area of ST6, and between STs 7 and 13. Should potentially intact features be encountered during trenching operations, $1 \times 1-$-m units should be excavated to further evaluate the overall significance of the site.

\section{Section II: Historic Components}

\section{$41 B P 138$ and $41 B P 105$}

\section{Background}

Although separated geographically, 41BP138 and 41BP105 both belonged to the same person, their historic components and intrinsic values are intermingled, and therefore both sites are included in the following discussion. Both sites contain prehistoric components also; those have been discussed in the previous section. Born in France on June 14, 1850, Antoine Aussiloux became a naturalized US citizen on August 3, 1875 (Moore 1977:240). By 1876, Aussiloux and a partner named 
Fred Gorton bought a 60-acre tract in Bastrop County (in present-day Camp Swift) from Patrick P. and Sarah Finnegan (Bastrop County deed dated Oct. 10, 1876, Vol. V, page 92) on which to plant grapes, and later construct a house and barn. At some point, Gorton departed the area and apparently left the operation to Aussiloux. Aussiloux later purchased additional acreage, constructed a dam, another barn, and an irrigation ditch, and planted more grapes. The history and brief biography of the owner of these properties, Antoine Aussiloux, and many details regarding construction and operations that occurred at both sites (41BP138 and 41BP105) have been succinctly documented in the Spring 1991 edition (pages 11-13) of the Sayersville Historical Association Bulletin (SHAB) with Jerry D. Frazee's article entitled The Legacy of
Antoine Aussiloux. Additional published and unpublished documents on Aussiloux and wine making can be found in Freeman (1979), Kay (1997), Gassaway (1997), and Leffler (2001). It is not our intent here to repeat what has previously been documented; we will merely synthesize pertinent points, and present any new information we have found in both our archaeological and archival work.

\section{Descriptions}

41BP138 is just one entity of a farmstead, vineyards, dam, irrigation system, and wine-making operation (see Figure 4-44). The historic component at 41BP138 consists of the structural remains of Frenchman, Antoine Aussiloux's home and barn; a prehistoric component at the site has been discussed in the previous section. The re-

FIGURE 4-44. REDACTED

Figure 4-44. Aerial photograph with locations of sites and features included in the text. 
mains of Aussiloux's house are surrounded by a chainlink fence, and are posted as "off limits" for military training. The sandstone foundation of Aussiloux's barn is located on the north side of Wine Cellar Road (see Figure 4-45). Ranging in elevation from 440-450 feet, it lies on a ridge in a generally open area bisected by Wine Cellar Road. Although Aussiloux planted grapes in the open fields in the late 1800s and early 1900s, they are now covered with scattered stands of oak and tall grasses supported by Demona loamy fine sand (DeC). In addition to the construction of Wine Cellar Road, bulldozing to presumably clear the area for training during WWII has impacted the site, and approximately $45 \mathrm{ft}$ east of the structure is a $49-\mathrm{x}-8$-ft clay borrow pit dug by the military.
An irrigation ditch constructed by Aussiloux ends at 41BP105 where he maintained other grape fields on a sideslope and lower terrace just west of the confluence of a spring-fed stream and Big Sandy Creek (see Figures 4-44 and 4-46). Sayers fine sandy loam ( $\mathrm{Sa}$ ) now supports small isolated oak and mesquite trees in the field, as well as thicker riverine trees and brush along the edges of both creeks. Grapevines are clinging to large trees surrounding the open fields (Figure 4-47), and some are present in the open field amidst tall grasses, however these may be wild species.

\section{Levels of Work and Results}

The House, Barn, and Grape Field (60-Acre Tract) - 41BP138

The Aussiloux homestead (41BP138) was initially recorded by Skelton and Freeman in 1979, and subsequentely revisited by Robinson et al. in 1997. In 2002, CAS photographed the Aussilloux House and surrounding features, and sketch maps were drawn of the remaining cellar and first floor stone walls. Photograph documentation included the stone cellar, stone steps, wooden joists for the first floor, partial stone walls, a sandstone lined well, a cistern near the corner of the house, and the barn.

The house walls are made of hand hewn red sandstone, and are approximately $1 \frac{1}{2}$ feet thick, with the highest wall remnant standing approximately 15 feet above the cellar floor. The cistern is located near the southeast corner of the

Figure 4-45. Site map, 41BP138. 
FIGURE 4-46. REDACTED

Figure4-46. Site map,41BP105. house and has an interior dimension of $3 \frac{1}{2}$ feet, while the stone lined well has an interior dimension of 6 feet in diameter (Figures 4-48 through 4-52).

Personal communication with Abner C. Scott. in January 2002 led CAS personnel to the remaining cornerstones of another of Aussilloux's structures. This was an open-ended utility barn with outside dimensions measuring 30 x 26 feet (see Figure 4-45). According to Frazee (1991:12), the “...barn was dismantled in 1942 ...to make the entrance gate-wall to Camp Swift." The red sandstone wall foundations remain-

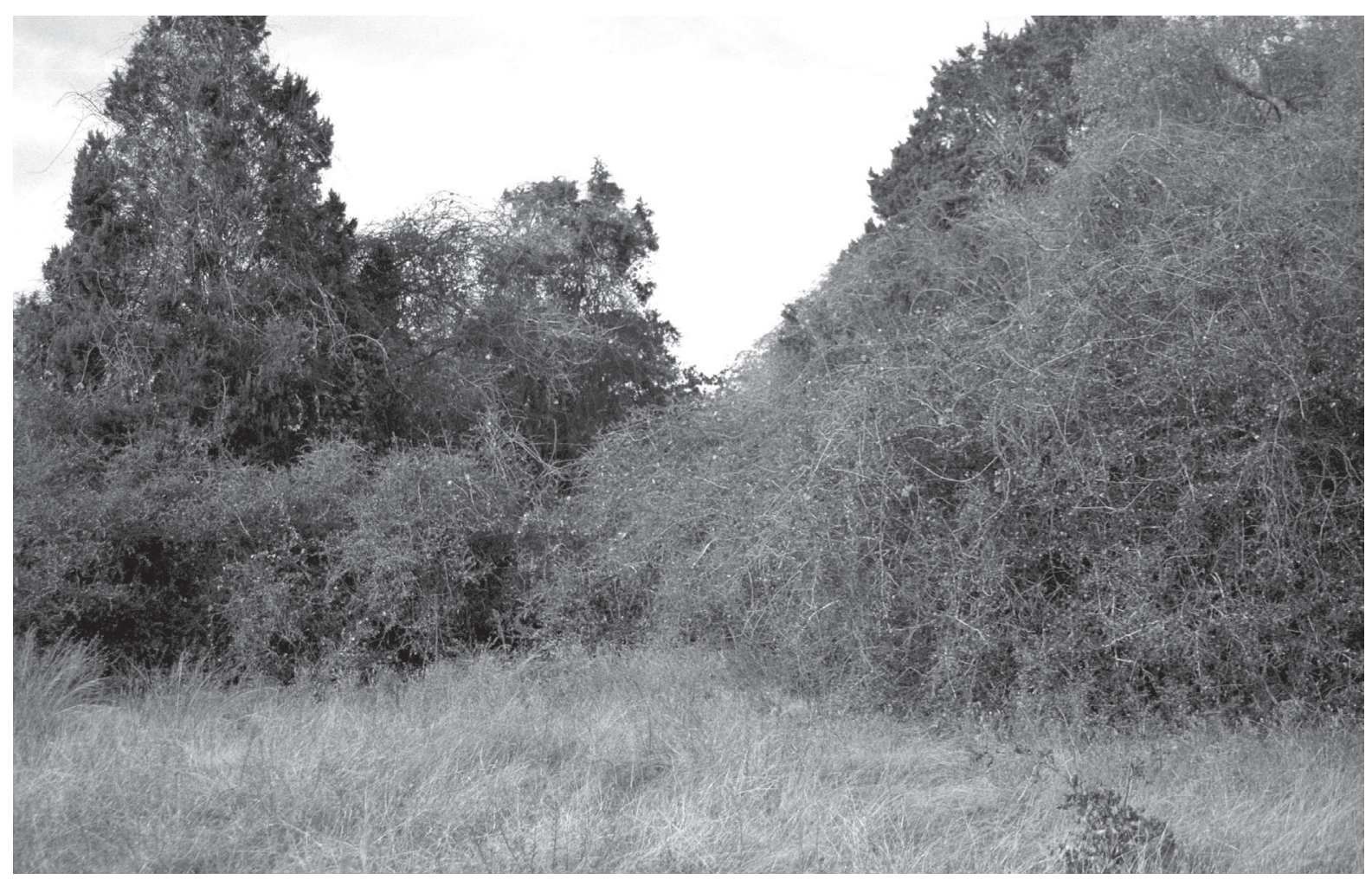

Figure 4-47. Grapevines cover the trees along the edges of Aussiloux's lower fields at 41BP105; facing west. 


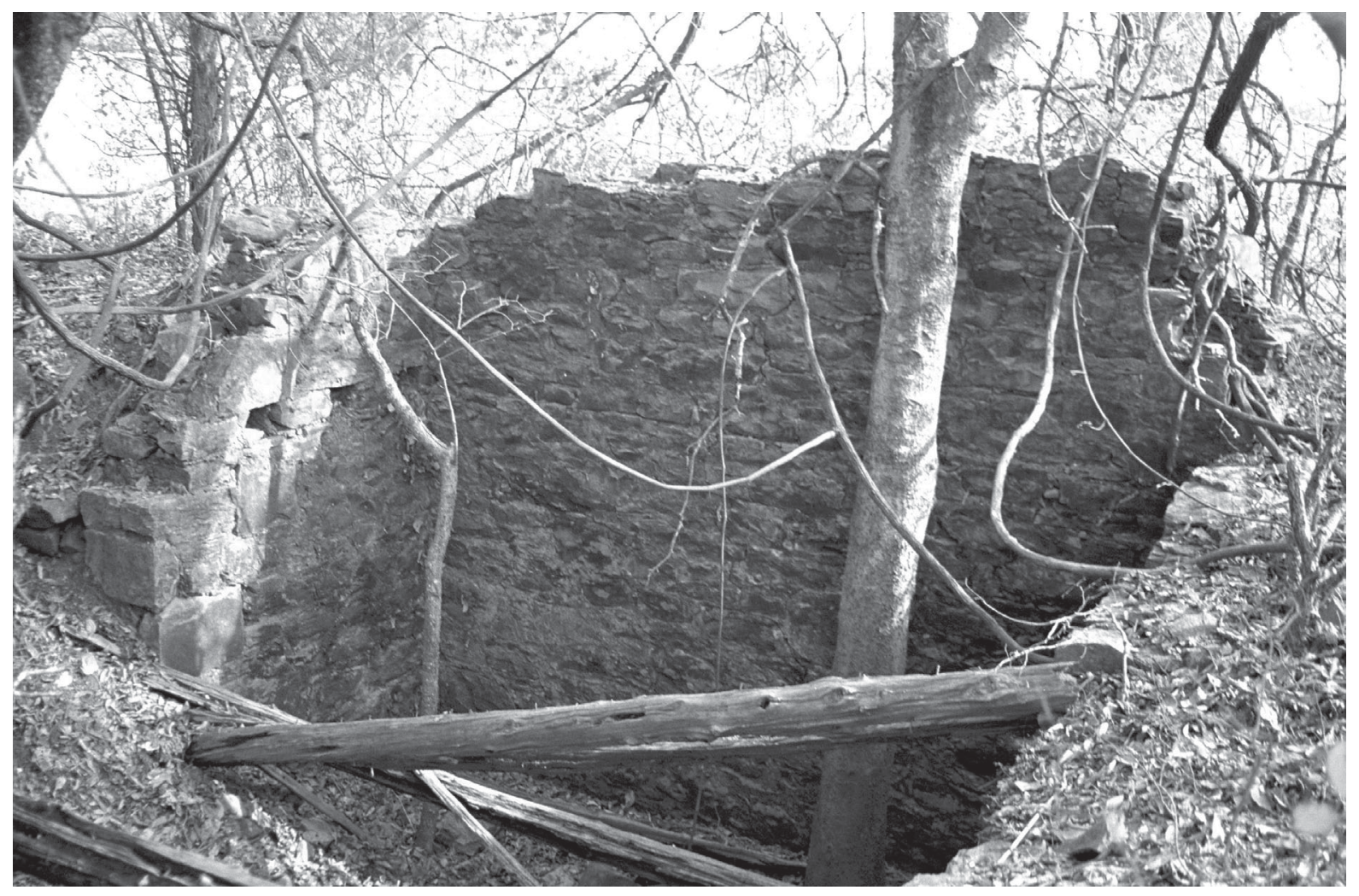

Figure 4-48. Remains of the cellar and first floor of Antoine Aussiloux's home; facing northeast.

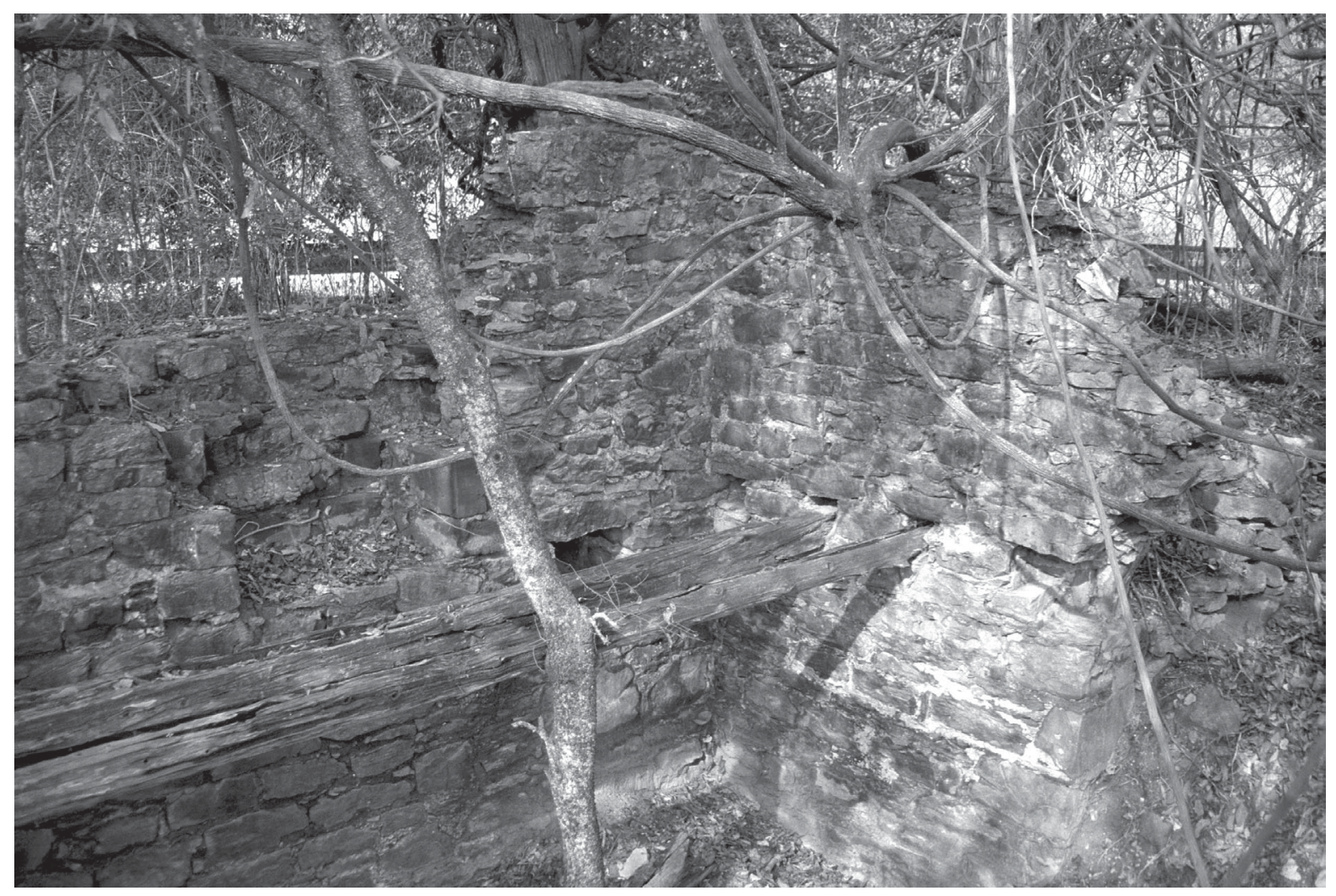

Figure 4-49. A few floor beams still remain; facing northwest. 
ing are approximately $19 \frac{1}{2} 2$ inches thick (Figure 4-53).

Frazee (1991:12) states that "Adjacent to the stone barn was a wine press turned by a long pole pulled around and around by a mule in the manner of a sugarcane mill. The juice ran into barrels for fermenting in the barn". Frazee noted that barrel hoops lying on the surface in recent times suggest that they were 30-gallon barrels. CAS archaeologists observed two such rusted barrel hoops on the surface near the barn in 2002. in an effort to locate other possible structures or features at the site, CAS archaeologists then excavated 44 shovel tests in a systematic pattern extending away from the barn and house. Historic artifacts recovered include 6 pieces of whiteware, 3 pieces of window glass, 1 piece of mortar construction material, 1 square nail, 19 pieces of scrap metal, 5 pieces of clear glass, and 3 pieces of light brown glass (Table 4-23). An examination of Table 4-23 (shovel

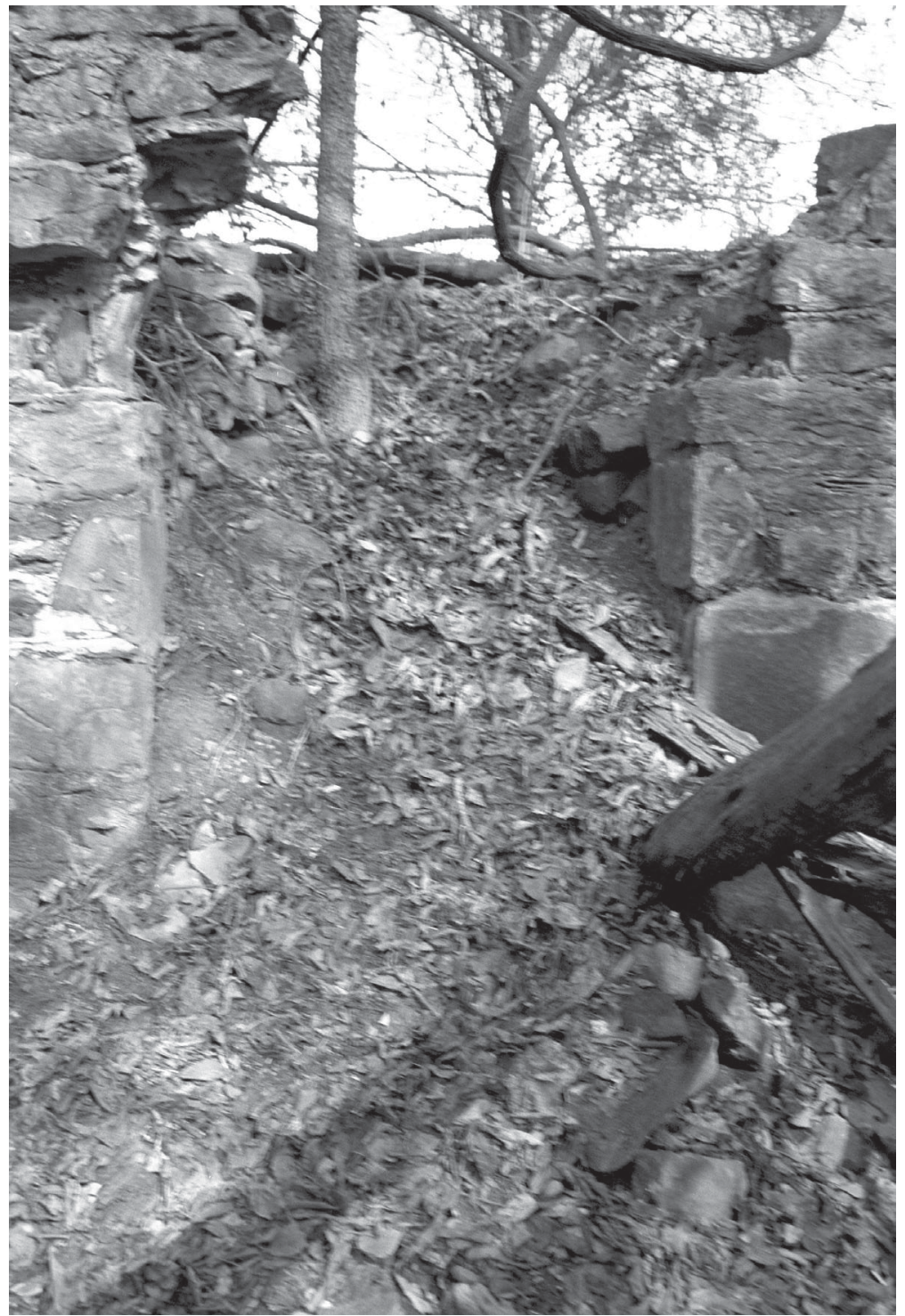

Figure 4-50. Debris-filled stone stairway leading from Aussilloux's cellar; facing north. test results) in corroboration with

Figure 4-45 (site map) indicates that: 1) we found no evidence of any other structures or features, and; 2) artifact classes (e.g., construction, household, operational) do not form any coherent pattern within the historic site boundaries, suggesting that below the surface they have been mixed both vertically and horizontally.

In addition to the barrel hoops on the surface in 2002, we observed a few pieces of whiteware and clear glass in the roadbed of Wine Cellar Road, and collected an ironstone china sherd with maker's mark from the surface near Shovel Test 27. The sherd is from a shallow saucer, and the maker's mark indicates it was manufactured by Wood \& Sons Company, Limited in Staffordshire, England. Although the exact year when this particular specimen was made cannot be determined, its unique mark indicates it was 1910 or later (Kovel and Kovel 1986:13), suggesting that the saucer was 


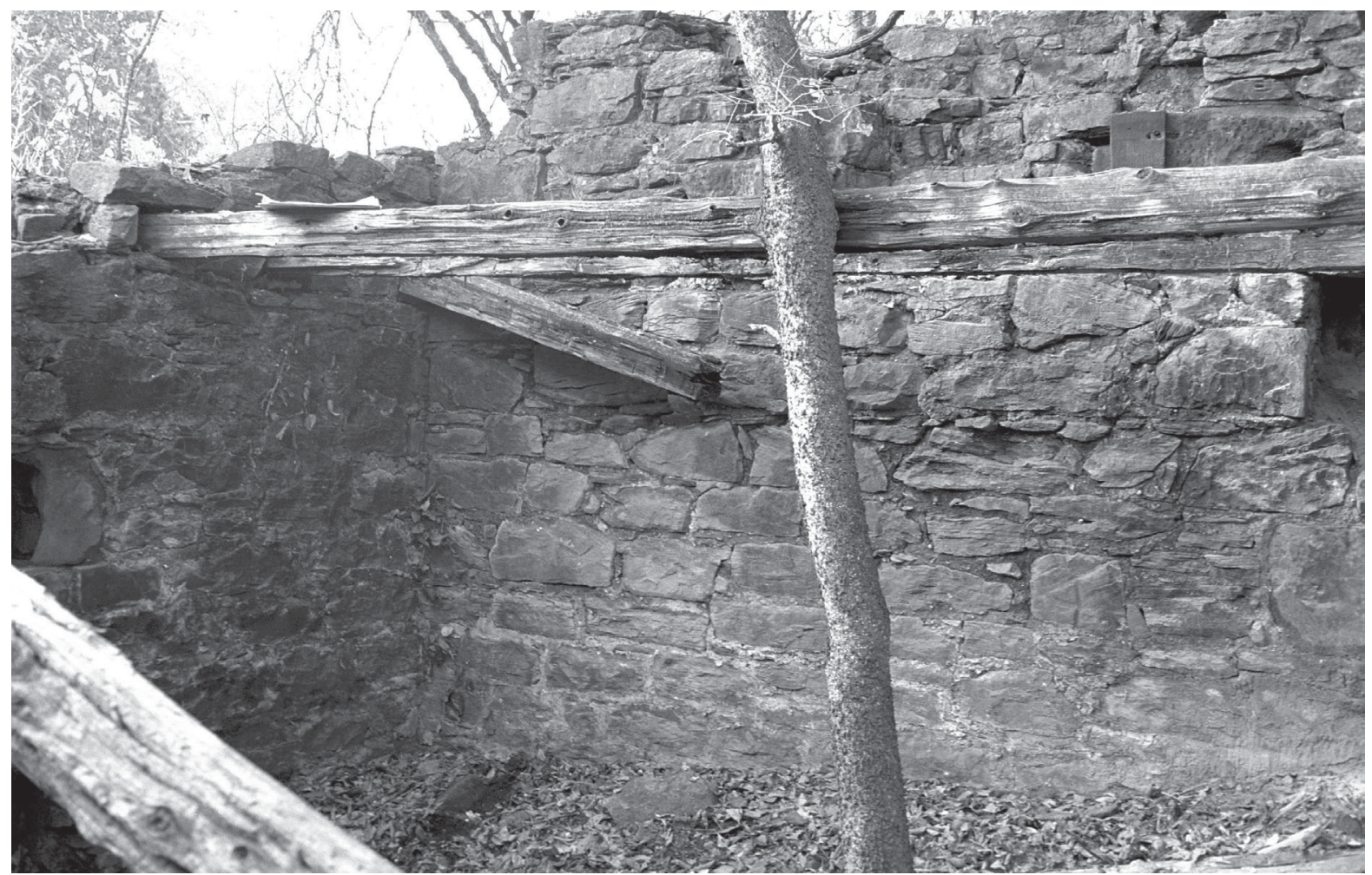

Figure 4-51. Cellar and first floor wooden beams in Aussiloux's home; facing southwest.

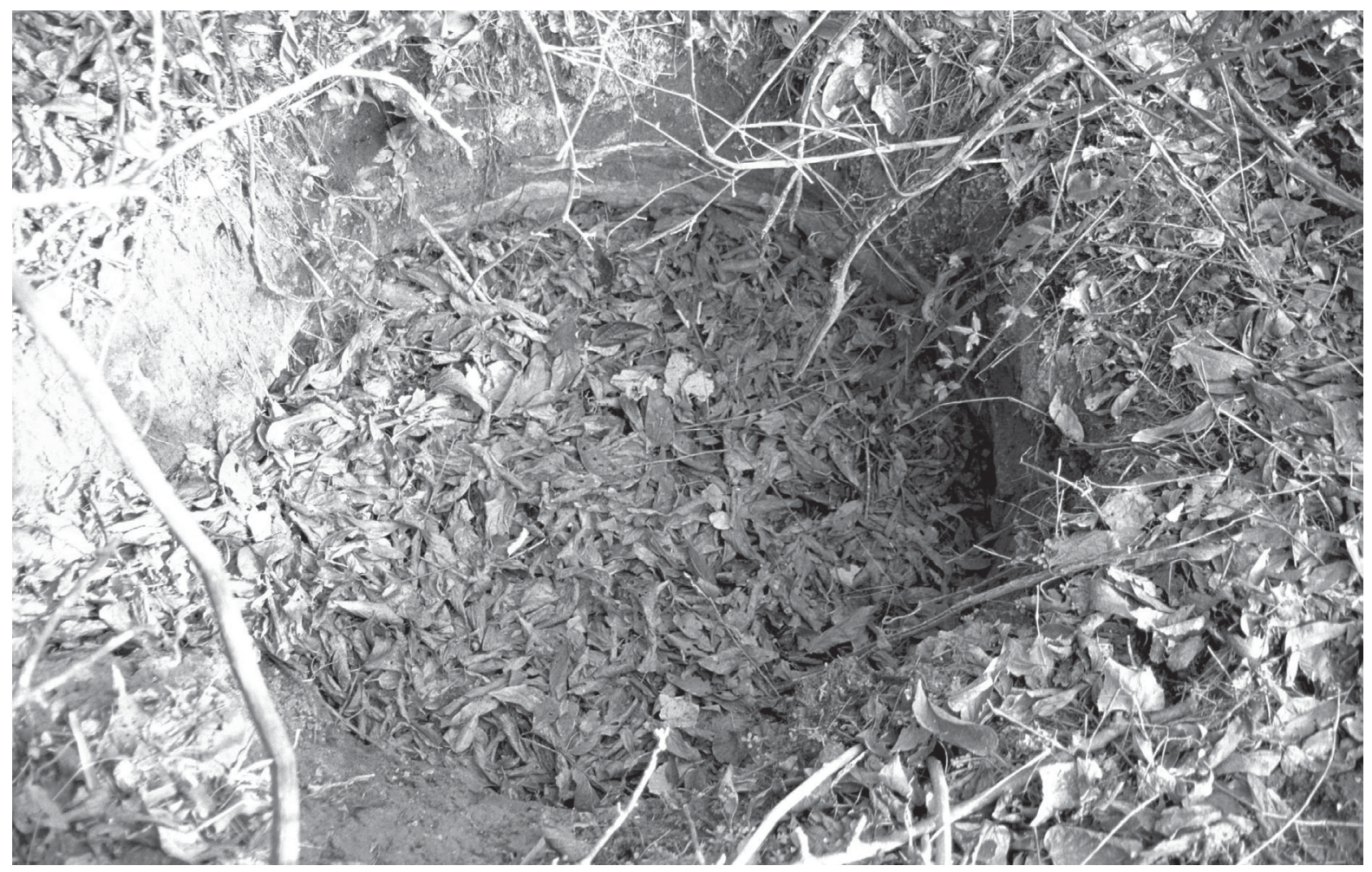

Figure 4-52. Stone-lined cistern adjacent to the corner of Aussilloux's home (see site map). 


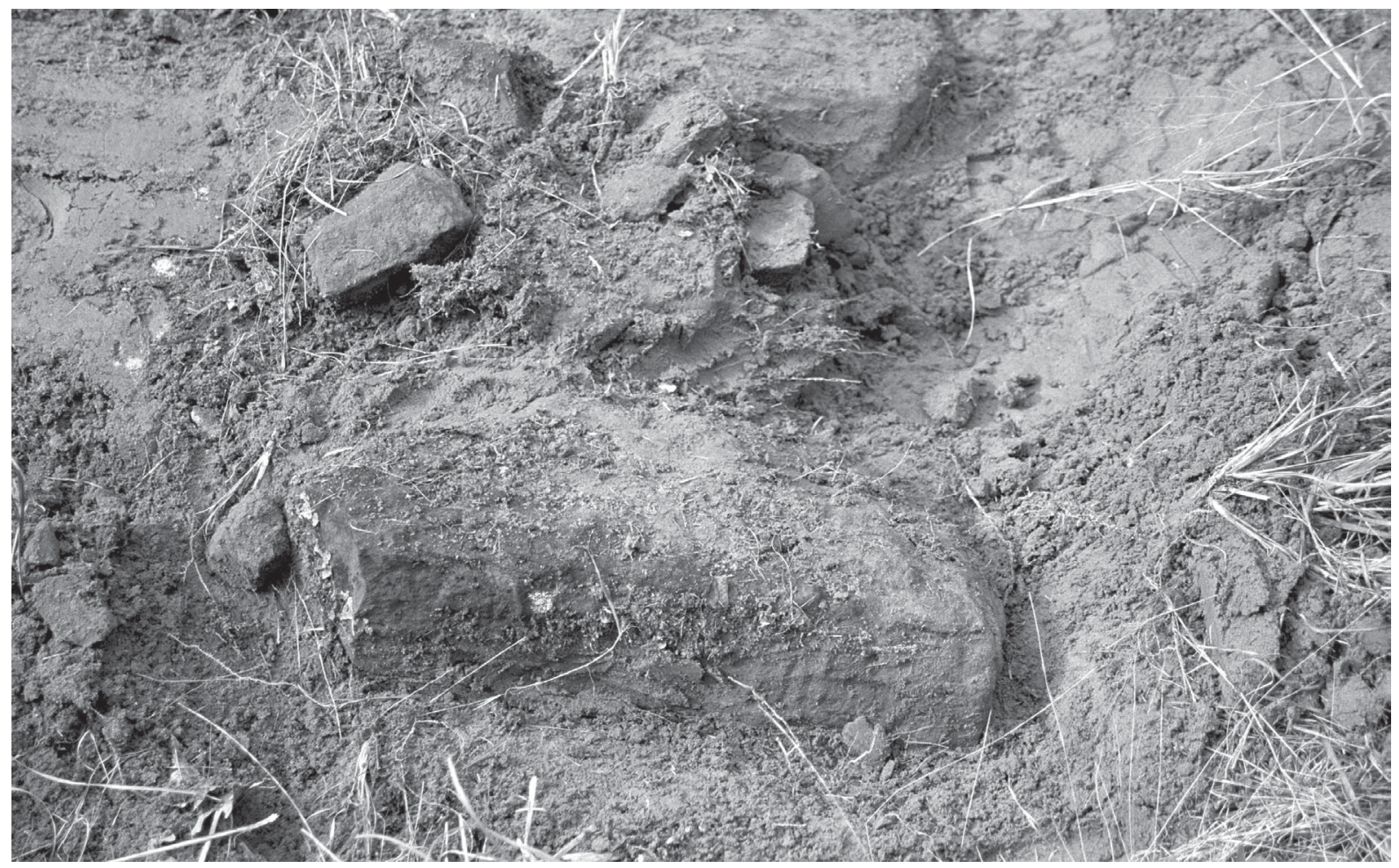

Figure 4-53. Cornerstone (sandstone) of Aussilloux's barn.

likely used by Antoine Aussiloux before he died in 1924.

By 1885, Aussiloux decided to expand his operation significantly with the purchase of an additional 40 acres for planting, and the construction of a dam and irrigation channel for a constant water supply. The 40 acres he purchased in 1885 from W.C. Rankin and wife (Bastrop County deed dated Jan. 8, 1885, Vol. 7, page 289) was to the north and east, near the confluence of Spring Branch Creek and Big Sandy Creek (see Figures 4-44, 455 through 4-57).

\section{BP105 - Lower Grape Fields}

As it happens, Skelton and Freeman documented a prehistoric component

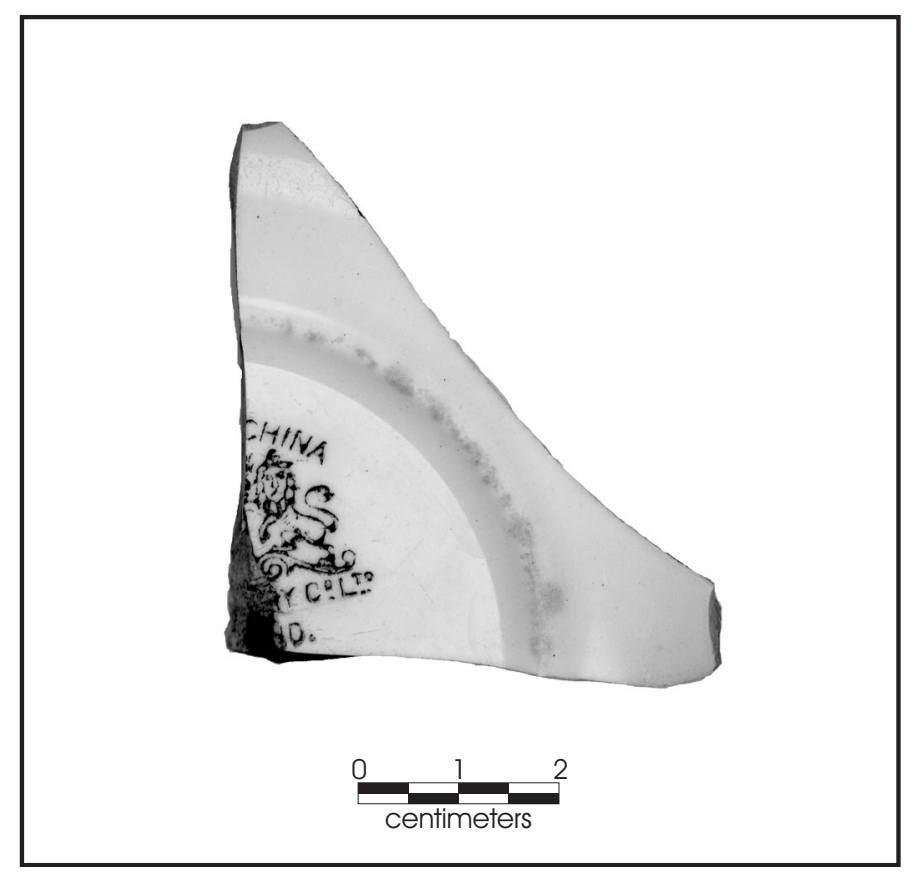

Figure 4-54. The Maker's mark on this ironstone sherd from a shallow saucer indicates it was manufactured in Staffordshire, England, perhaps as early as 1910 . 


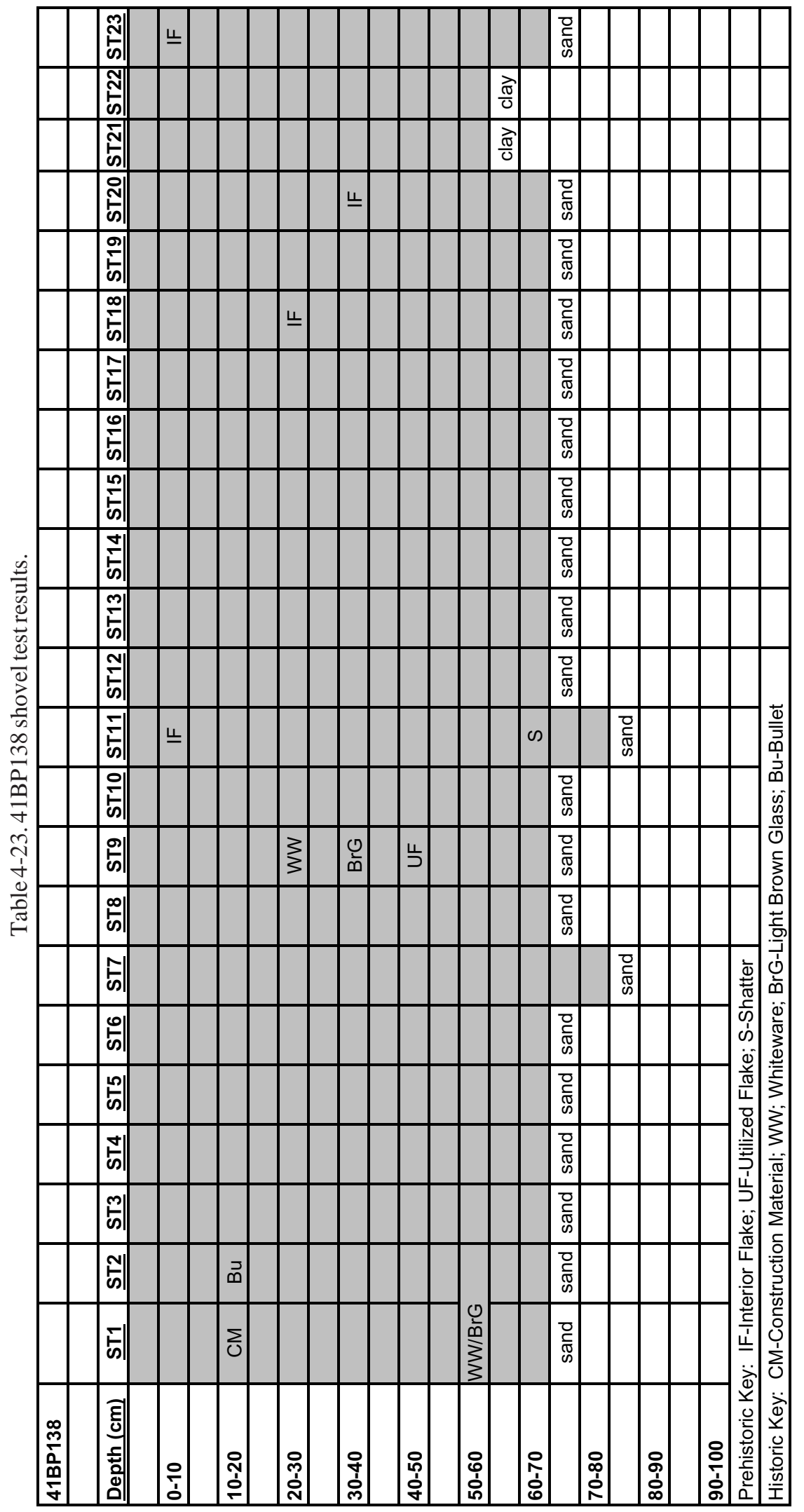




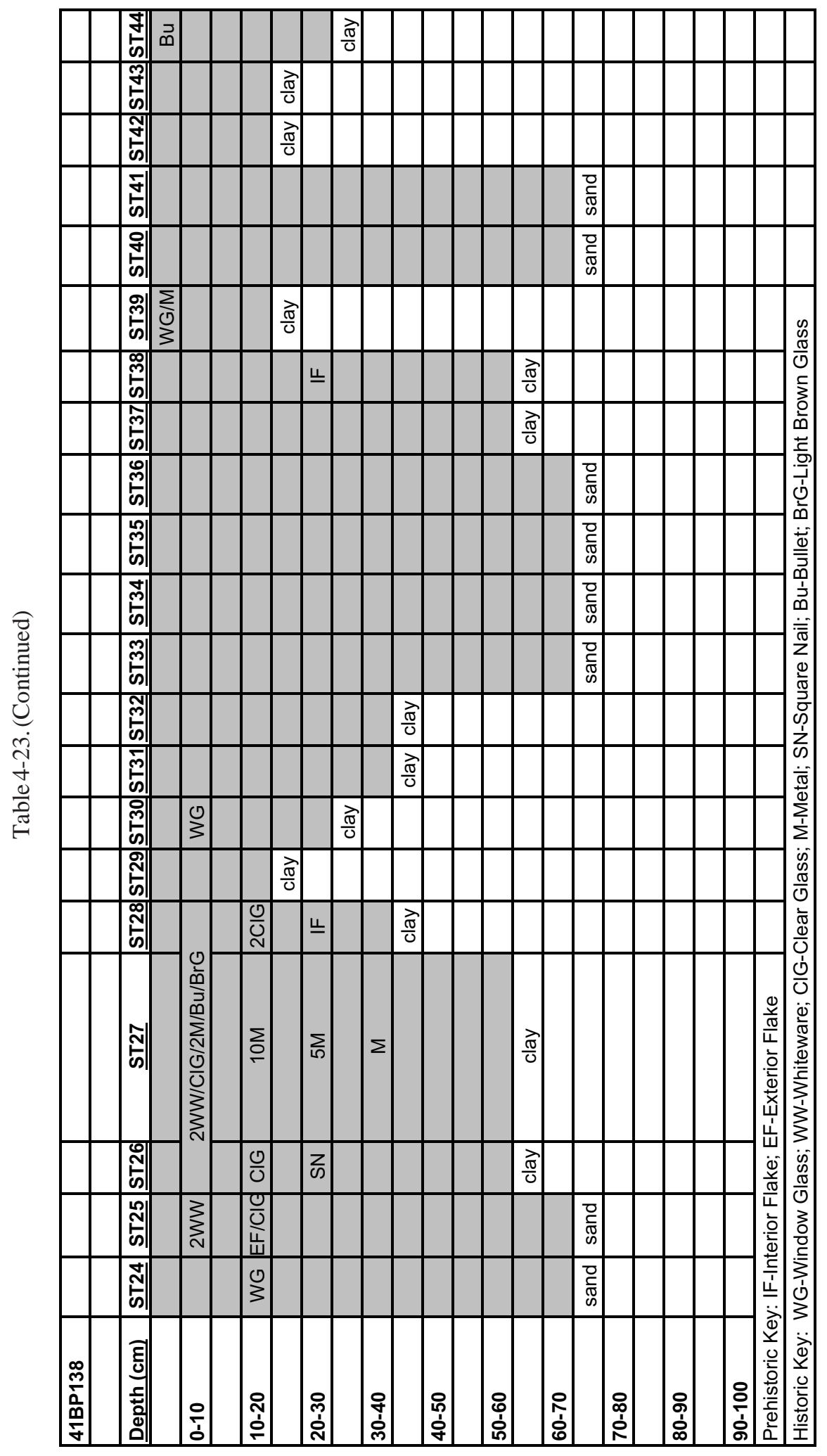




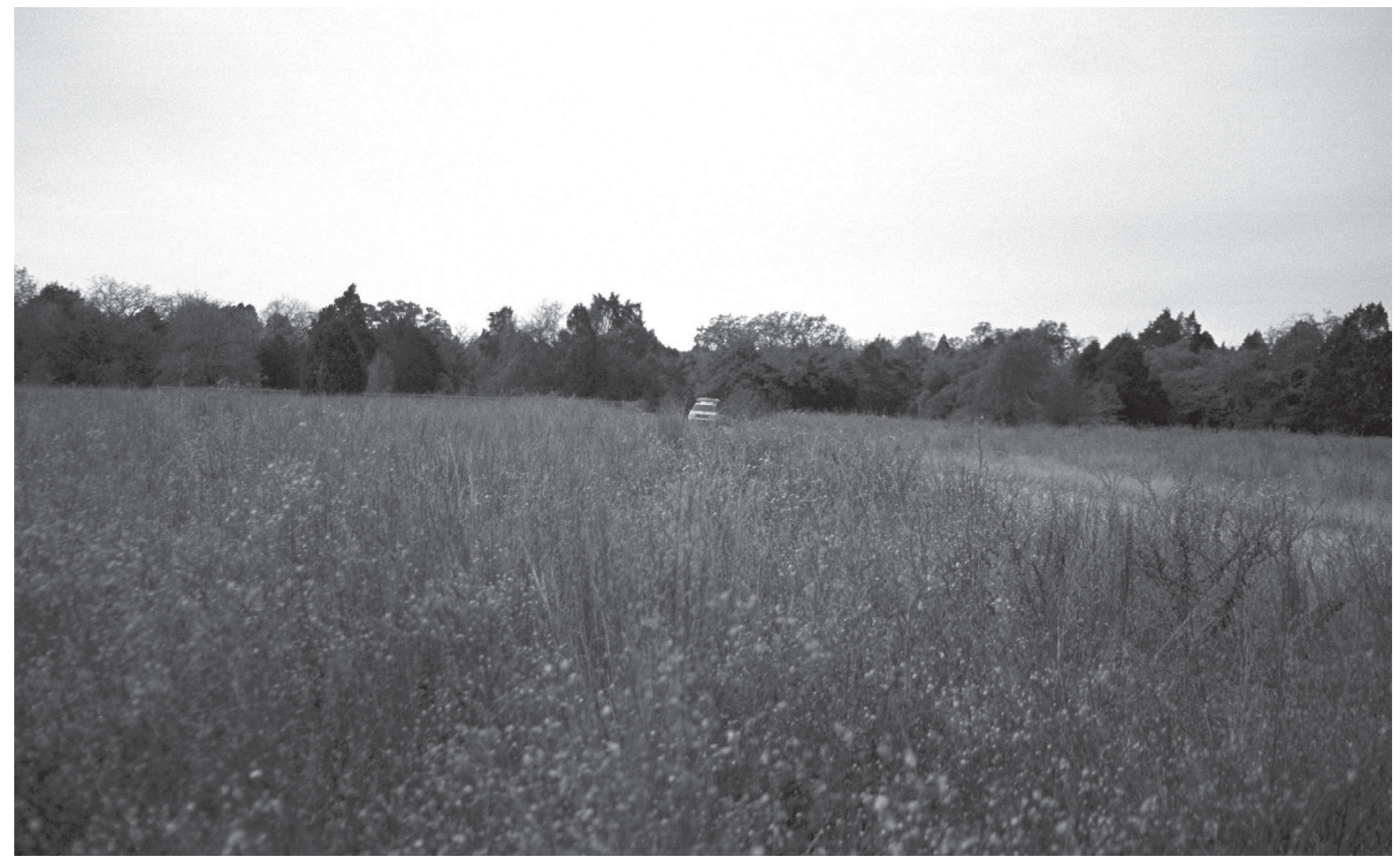

Figure 4-55. A view toward Aussiloux's house (left of vehicle) and barn (right and beyond vehicle). This field was part of his 60 -acre purchase in 1876; facing southwest.

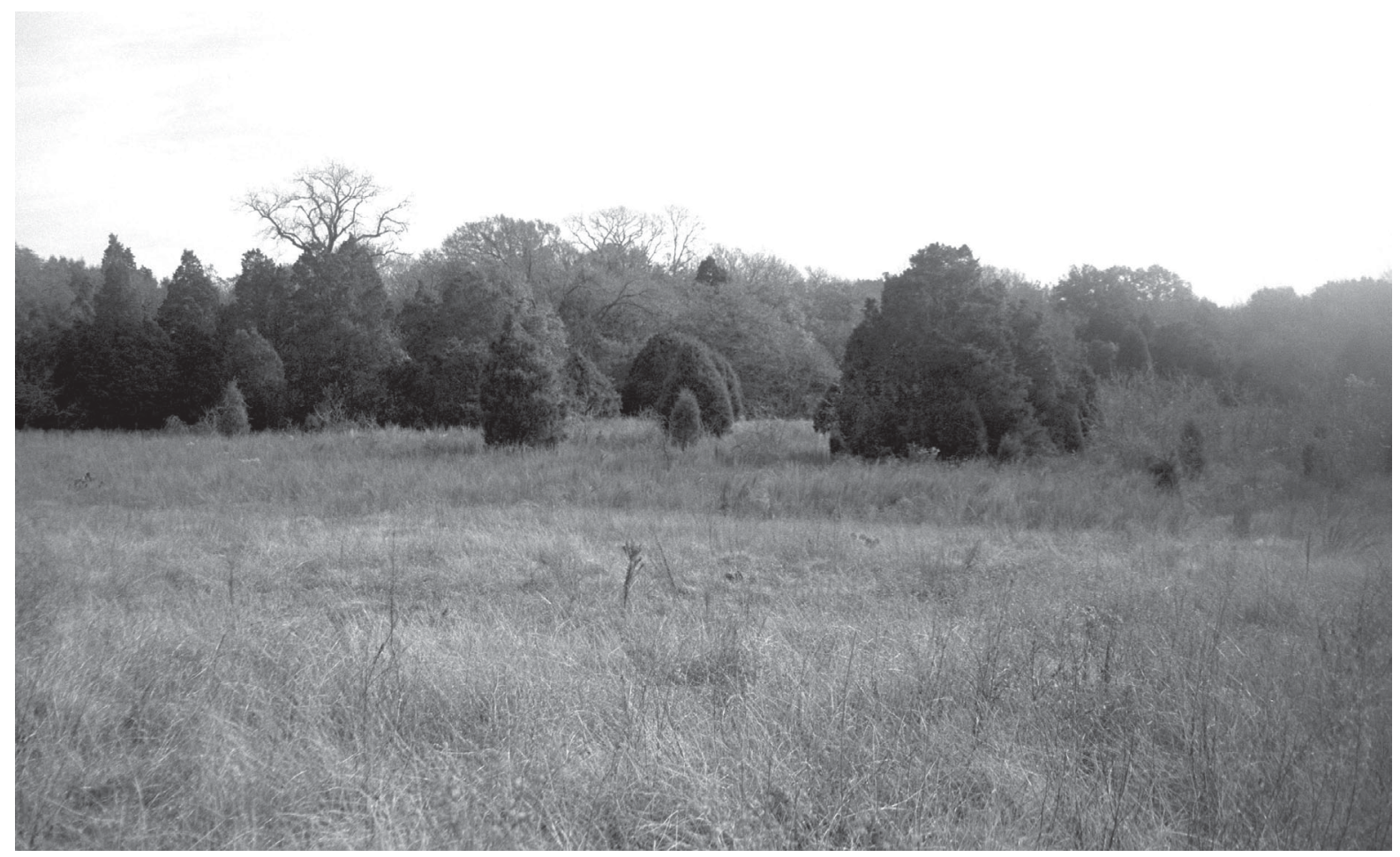

Figure 4-56. Aussiloux's lower grape field on a sideslope, near the confluence of Spring Branch Creek and Big Sandy Creek. 


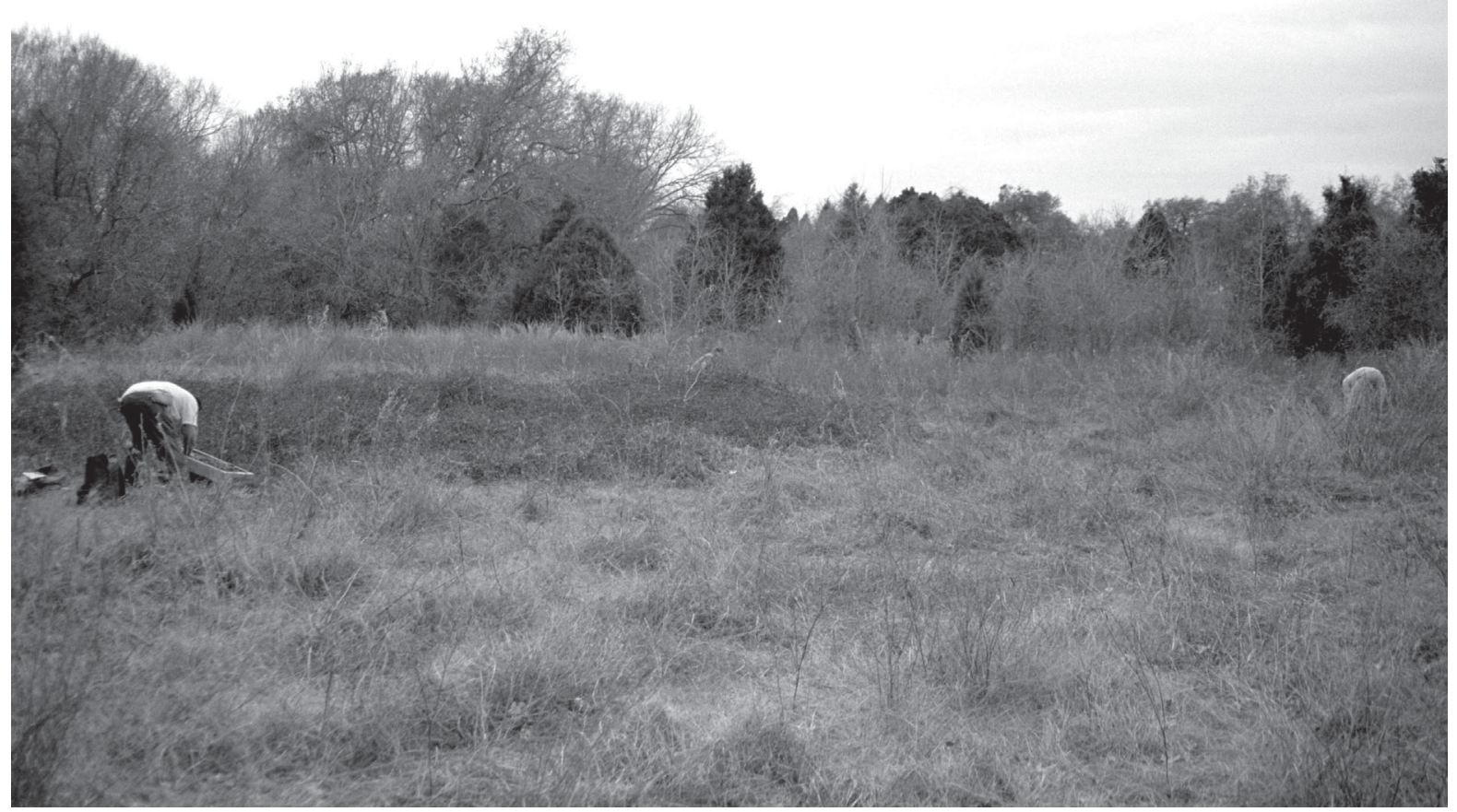

Figure 4-57. Aussiloux's lower grape fields on a lower terrace, near the confluence of Spring Branch Creek and Big Sandy Creek.

(41BP105) on a lower terrace within the 40-acre tract purchased by Aussiloux. While revisiting the site in 2002 to further evaluate the prehistoric component, CAS archaeologists recovered a stoneware sherd very similar to Beauvasisis stoneware from between $60-70 \mathrm{~cm}$ below the surface in Shovel Test 14 (see Figures 4-58 and 4-59). Beauvaisis was a center of stoneware production in France (Chrestien 1995). This was the only significant historic item recovered; other items included a bullet and a piece of clear glass in the upper 10-30 $\mathrm{cm}$. However, a distinct soil change was detected while shovel testing; unlike elsewhere on the site

FIGURE 4-58. REDACTED

Figure4-58. Site map,41BP105. 


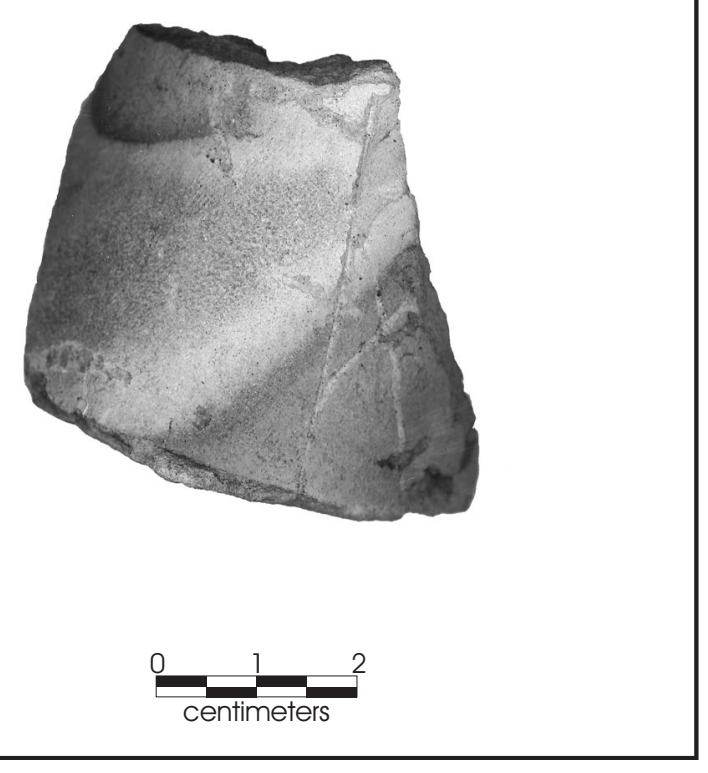

Figure 4-59. This stoneware sherd was found between $60-70 \mathrm{~cm}$ below the surface in Shovel Test 14 (see site map).

where deep sands were encountered, along the western edge (Shovel Tests 17-19), we encountered clayey, ponded sediments within the upper 10 $\mathrm{cm}$. This ponded area may represent a deltaic accumulation at the end of an irrigation ditch constructed by Antoine Aussiloux to water his grape fields at this location, or it could be the remnants of an old road shown on early topographic maps.

\section{Construction of the Dam and Irrigation Ditch/40-Acre Tract}

In order to procure a constant source of water for his grape fields on the lower portion of his 40acre plot, Aussiloux and his partner, Fred Gorton purchased two small tracts of land on both sides of the upper portion of Spring Branch Creek. For \$25 each, they purchased $1 \frac{1}{2}$ acres located on the northeast bank of the creek from Jno. Henry Springer (Bastrop County deed dated Sep 7, 1885, volume 16 , page 439 ), and $1 \frac{1 / 2}{2}$ acres on the south- west bank from Abner Scott (Bastrop County deed dated Sep 7, 1885, volume 16, page 438). Aussiloux then constructed a sandstone dam across the creek, creating what is known as Scott Falls (Figures 4-60 through 4-62). According to Abner C. Scott (personal communication, January $16,2002)$, an opening on the western edge of the dam allowed for a metal conduit extending perpendicular from the dam (Figure 4-63). After leaving the metal conduit, the water flowed into an earthen channel.

In 2003, CAS archaeologists were able to retrace the route of the nearly .7-mile long ditch (1,185 meters), beginning at Scott Falls and becoming very ephemeral in nature at a point just above Aussiloux's fields (see Figure 4-44). Abner C. Scott (personal communication, January 16, 2002) stated that the entire ditch was lined with sheet metal. However, we did not observe any portion of the ditch that was metal lined, suggesting that the metal may have been either removed by the military, much as buildings on the Camp were destroyed, or the metal may have become part of a WWII scrap metal salvage effort. Excavated along the edge of the creek, some remnants of the ditch are still very much visible, ranging in depth from 6 to 24 inches in some stretches, and as deep as 6 feet in one short stretch. In some areas, erosion and vegetation has obliterated portions of the old ditch. According to Frazee (1991:12), "The forty-acre tract became the only irrigated vineyard of that period in Texas." Interestingly, we found another ditch running parallel to Aussiloux's ditch (see Figure 4-44). It is unknown whether the parallel ditch was at one time connected to Aussiloux's and erosion has obliterated their confluence, or whether the parallel ditch is someone else's attempt at irrigation. 


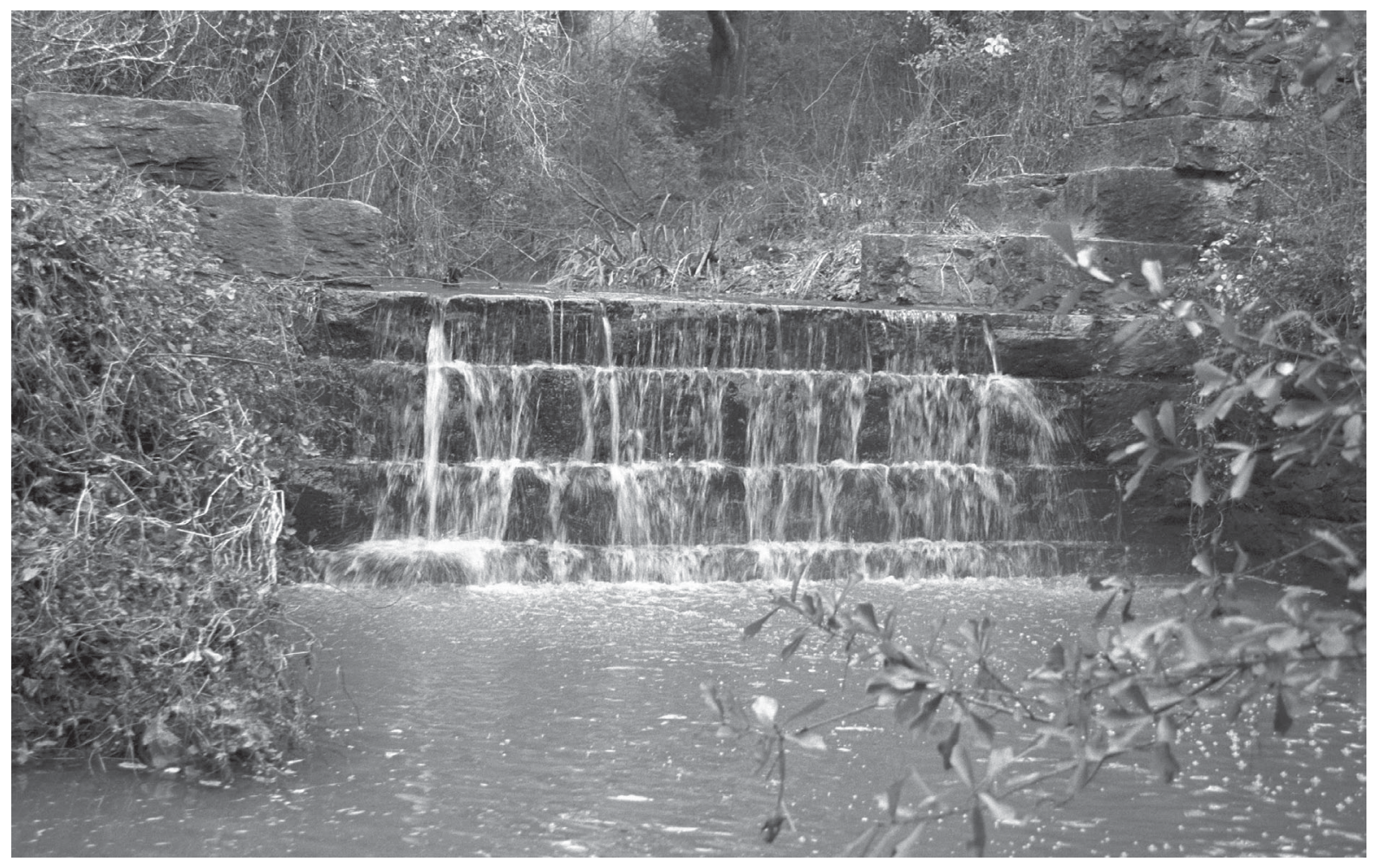

Figure 4-60. French engineer and winemaker Antoine Aussiloux constructed this sandstone dam over Spring Branch (Scott Falls Creek) around 1886.

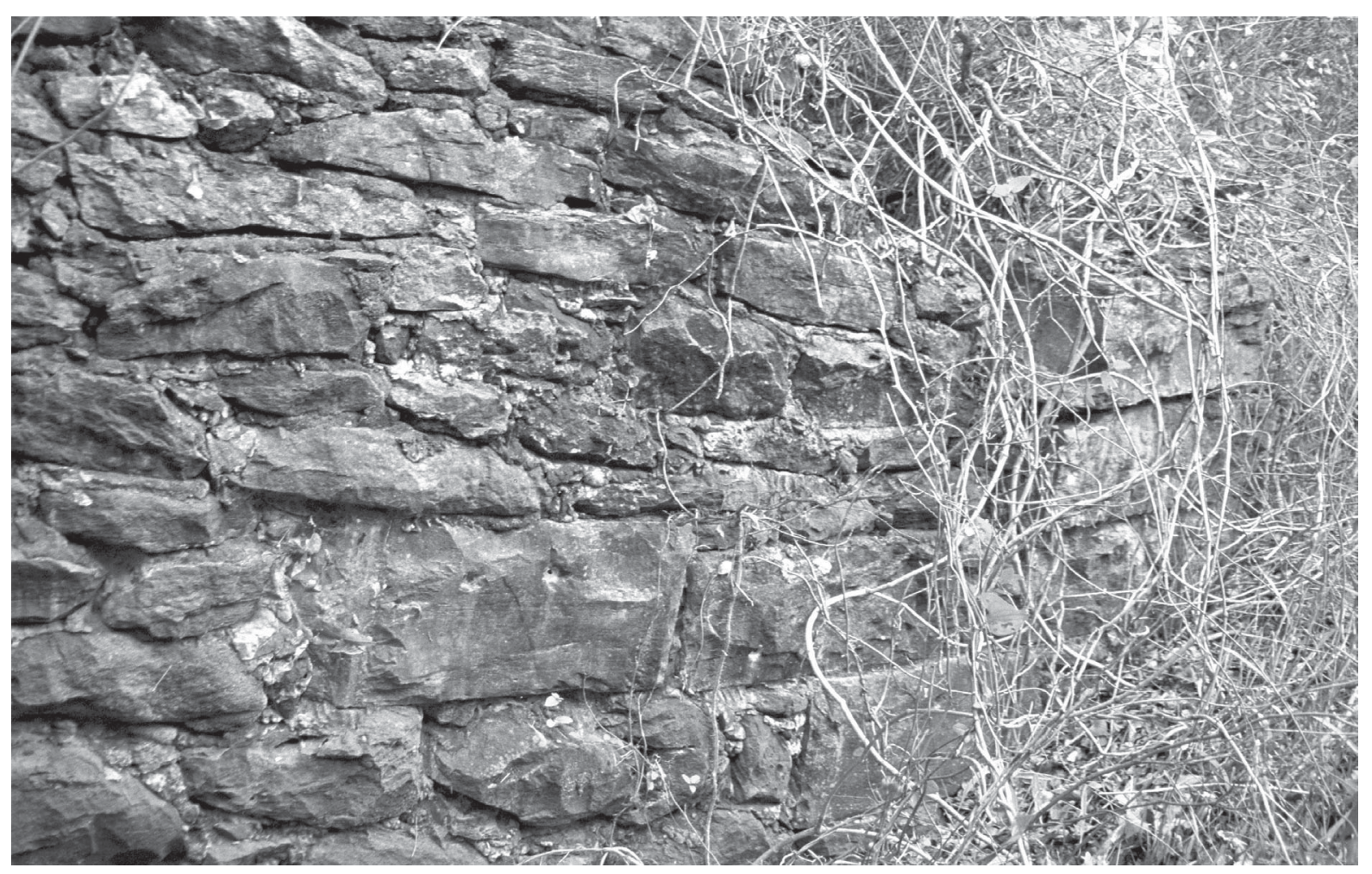

Figure 4-61. Away from the main course of the creek, Aussiloux used smaller sandstone blocks and slabs, with coarse mortared chinking; facing west. 


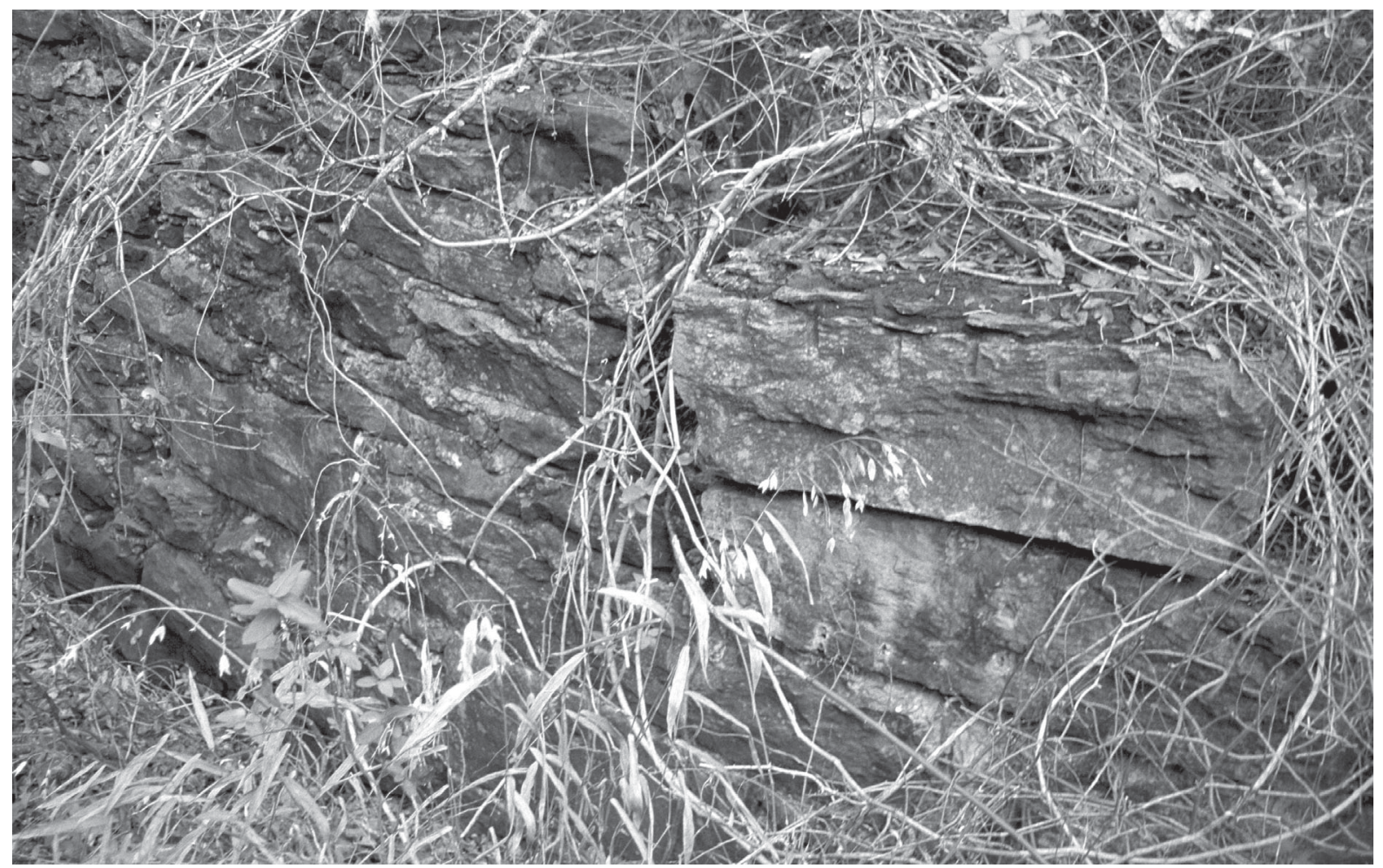

Figure 4-62. Note the drill bit markings in the upper right sandstone slab.

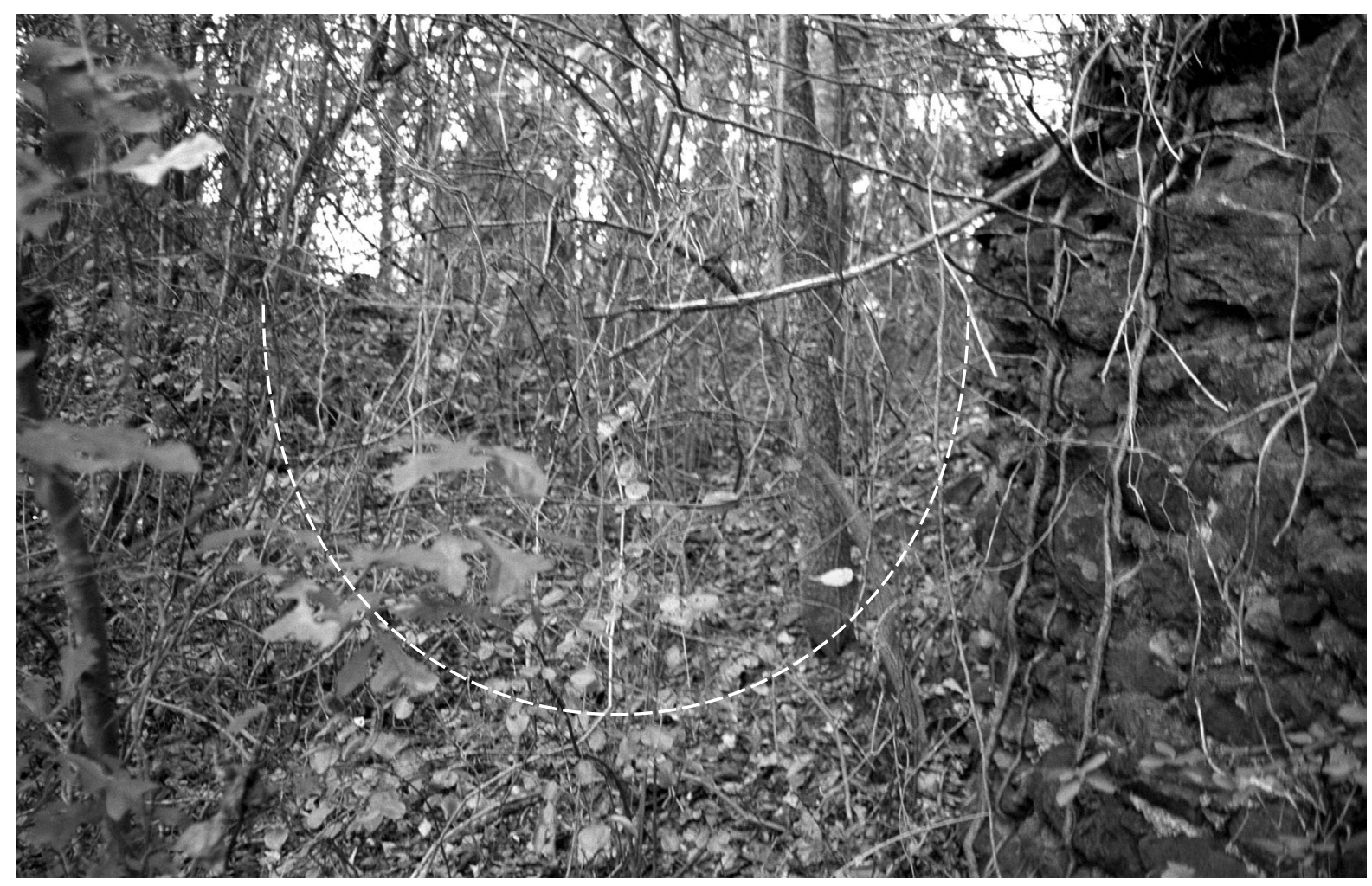

Figure 4-63. This photo shows the opening on west end of Aussiloux's dam, with the white line indicating where a metal conduit was installed to direct the flow of water into an irrigation ditch. The ditch ended nearly .7 mile at his grape fields. 
The manner in which water was funneled into the irrigation channel is debatable. Frazee (1991:12) states that Aussiloux probably used ropes and pulleys to siphon water over the dam so it could feed an irrigation channel leading from the dam to his lower grape fields on the 40-acre tract, and that he "...constructed a wooden barn near the Spring Branch to hold equipment such as ropes and pulleys." Frazee interpreted the opening in the central portion of the dam as a designed spillway.

However, as stated previously, Abner C. Scott maintained that the opening for the metal conduit (as seen in Figure 4-63) was on the western end of the stone dam, and water flowed through the opening into a metal conduit or flue (personal communication January 16, 2002). Mr. Scott stated that the 9-foot-high gap in the dam we see today as a spillway was originally filled in on a level with the top of the rest of the dam, but the stones have since been removed; possibly for construction elsewhere (as with Aussiloux's barn). The headwaters of the many Spanish acequias (irrigation ditches) constructed in and around San Antonio derive from weir dams constructed across creeks and rivers. The weir dams simply served to raise the level of the water behind the dam so that the overflow was diverted into a ditch. We surmise that this is how Aussiloux designed the dam on Spring Branch.

\section{The Demise of the Winery and Antoine Aussiloux}

The Texas wine business prospered for approximately 30 years, from 1870 to 1900 (Frazee 1991:13). A man by the name of Thomas V. Munson, often called the "father" of Texas viticulture was one of the most renowned grape breeders and viticulture authorities in the nation. As a grape breeder from the late 1800s to about 1910, Munson produced approximately 300 varieties of grapes better suited to the Texas environment (Templer
2003). Perhaps Aussiloux met Munson, as some of Munson's hybrid grapes were grown in the area (Frazee 1991:13). The wine business continued to prosper until the 1890s when refrigerated railroad cars began bringing in mass-produced keg beer (Frazee 1991). Also in 1907, The Anti-Saloon League formed and was a contributing factor in the temporary elimination of the legalized alcohol industry. State Prohibition followed thereafter, and was later ratified as a federal amendment in 1919 (Templer 2003).

Inevitably, Aussiloux let his fields go untended; instead he farmed and tended cattle until his death on March 9, 1924 (not December 9 as stated by Frazee 1991:13; see Bastrop County Probate Minutes, Book O-1924, pages 352-354). According to Frazee (1991:13), a neighbor found Aussiloux lying dead in his front yard. Aussiloux passed away en teste, that is, without a will. C.R. Branton petitioned to be the administrator of the estate in lieu of Aussilloux's half brother, and on December 9, 1924 his petition was approved.

According to probate minutes, the law firm of Webb and Webb published a notice to debtors and creditors in the Elgin Courier on December 11, 18, and 24, 1824 and January 1, 1925 (Bastrop County Probate Minutes, Book O - 1924, pages 352-354). Branton continued to produce annual reports of the estate when in 1942, he said that the 100 acres in the Bastrop area would probably be condemned for military usage. Also mentioned was that a part of a lot Aussiloux owned in Elgin had been condemned by the county for road construction purposes. In 1953, according to Branton's fifth and final report, the estate consisted of $\$ 606.00 \mathrm{in}$ cash and a portion of the lot in Elgin. The remaining part of that lot was later sold for $\$ 50.00$ to Fletcher Ramirez, Jr. The heirs of the estate had been located in the Republic of France and were the nieces and nephews of 
Aussiloux, however, no correct heirship affidavit had ever been furnished. C. R. Branton received $\$ 50.00$ and Webb and Webb attorneys received $\$ 325.00$ for their parts in administering the estate. In November, 1953, a check for $\$ 237.47$ was paid to Tignal Jones, County Clerk for deposit in the Registry of the Court to the unknown heirs of A. Aussilloux (Bastrop County Probate Minutes, Book 3, 1953, pages 32-34).

\section{Conclusions/Recommendations}

Although shovel testing around Ausiloux's house and barn (41BP138) failed to produce evidence of additional structural features or intact deposits, additional archival investigations and limited pedestrian survey unveiled additional information about Aussiloux. Shovel testing at his lower grape fields (41BP105) yielded a French ceramic piece identified as Beauvaisis stoneware. By conducting additional pedestrian survey, we were able to trace the nearly .7-mile course of an irrigation ditch excavated by Aussiloux from its beginning at Aussiloux's dam across Spring Branch to its end near his lower grape fields.

The remarkable history and significant accomplishments of Aussiloux and his winery operation attribute a high research value to this area. We agree with Mauldin (2001:176) that the entire operation "provides a glimpse into the early-Texas wine industry from the mid-nineteenth to earlytwentieth century". Components of the operation include:

1) $41 \mathrm{BP} 138$ - House/wine cellar, barn, cis tern, well,

2) Upper grape fields

3) Irrigated lower grape fields (including 41BP105)

4) Scott Falls Dam - Sandstone dam

5) Irrigation channel
As synthesized here, and as discussed elsewhere (e.g., Freeman 1979; Frazee 1991), we assess that 41BP138 is significant in that it:

A) is associated with events that have made a significant contribution to the broad patterns of our history; or

B) is associated with the lives of persons significant in our past; or

C) embodies the distinctive characteristics of a type, period, or method of construction, or that represents the work of a master, or that possess high artistic values, or that represent a significant and distinguishable entity whose components may lack individual distinction; or

D) has yielded, or may yield, information important in prehistory or history.

In addition, we believe that the integrity of three components [1] House/wine cellar, barn, cistern and well, [4] Scott Falls Dam, and [5] Irrigation channel) provide significant historical value in relation to like properties with a similar cultural theme, within the same geographical area, and generally within the same time frame. Therefore, we assess these three out of five components of Aussiloux's winery operation as eligible for nomination to the National Register of Historic Places (for 41BP105, see also Section I: Prehistoric Components).

However, due to the diversity of properties, we recommend specific means of protection for each as follows:

1) Aussiloux's house, cistern, and well are currently surrounded with a chain link fence and off limits to military training; we recommend no change.

2) Aussiloux's barn foundation should be surrounded with off-limits signs and Seibert stakes.

3) Aussiloux's irrigation ditch is heavily eroded in some areas, quite visible in others. The canal can be traced for 20 meters below the dam adjacent to 
Spring Branch Creek, and this remnant section should be placed off limits to heavy equipment and digging below Scott Falls Dam. A second remnant section 30 meters long just east of Wine Cellar Road is also very visible. This 30 -meter section should also be placed off limits to heavy equipment and digging (see Figure 6-1).

The upper and lower fields should not be eligible for NRHP nomination because they lack any preserved evidence of integrity, but a request for Determination of Effect should be submitted to the Texas Historical Commission before the fields are further impacted. The 60 -acre open field tract adjacent to Aussiloux's house and barn has never had any known structures on it. According to Abner C. Scott (personal communication, 29 April and 29 June 2004), the upper 60 acres was plowed by him for many years following Aussiloux's death in 1924. The Scott family raised sweet potatoes, watermelons, cantaloupes, and sweet peas on the property. In addition, both fields have been periodically used for heavy equipment training by the military since 1942 . More recent activities include trenching for tank concealment.

Both fields are deemed critical to the training of heavy equipment operators for the military. Current tactical training activities scheduled for these areas include deep trenching for tank emplacement and concealment. The fields are considered desirable for this type of training because of their openness and their positions on the landscape.

Therefore, we recommend that the 60 -acre upper field be placed off limits for any type of military training until a Determination of Effect is submitted to the Texas Historical Commission describing the type of military training that needs to be conducted in this area. For example, if digging either by hand or heavy machinery is conducted, the holes and trenches should be backfilled and the field leveled to its original grade.

Aussiloux's lower field consisting of two to three acres encompasses 41BP105 (a half-acre prehistoric site). As for the field area outside 41BP105, we recommend the same as for the 60acre tract. The open field area that comprises prehistoric site 41BP105 should be placed off limits until its significance is determined.

\section{BP146}

\section{Description}

41BP146 is an historic gravesite nestled in a heavily wooded area on a 5-m-high bluff at the confluence of two intermittent drainages (Figures 4-64 and 4-65). An old barbwire fence runs northsouth along the edge of both drainages. Directly east of the grave is an adjoining open field surrounded by old fence posts. Upslope and to the east are the remains of a historic farmstead (41BP147).

\section{Levels ofEffort and Results}

The grave was initially recorded by Skelton and Freeman in 1979. Their informant, Ina Fay Scott, said that the grave dated from the period of her husband's grandparents' occupation of the area. They noted that the structure contained five cut slabs of ironstone that enclosed an area of 30" x 50". Four upright slabs formed a rectangular enclosure, with a fifth large slab covering the top. Robinson et al. attempted a revisit in 1997, but they could not relocate the site.

In 2003, CAS-SWT personnel were able to relocate the grave, photograph it, GPS its location, and draw sketch maps of the grave and general area. Ranging in thickness from $4^{1 / 2 "}$ to $5^{7 / 8^{\prime \prime}}$, the material is actually sandstone, and all slabs had chisel marks on them from being quarried and 


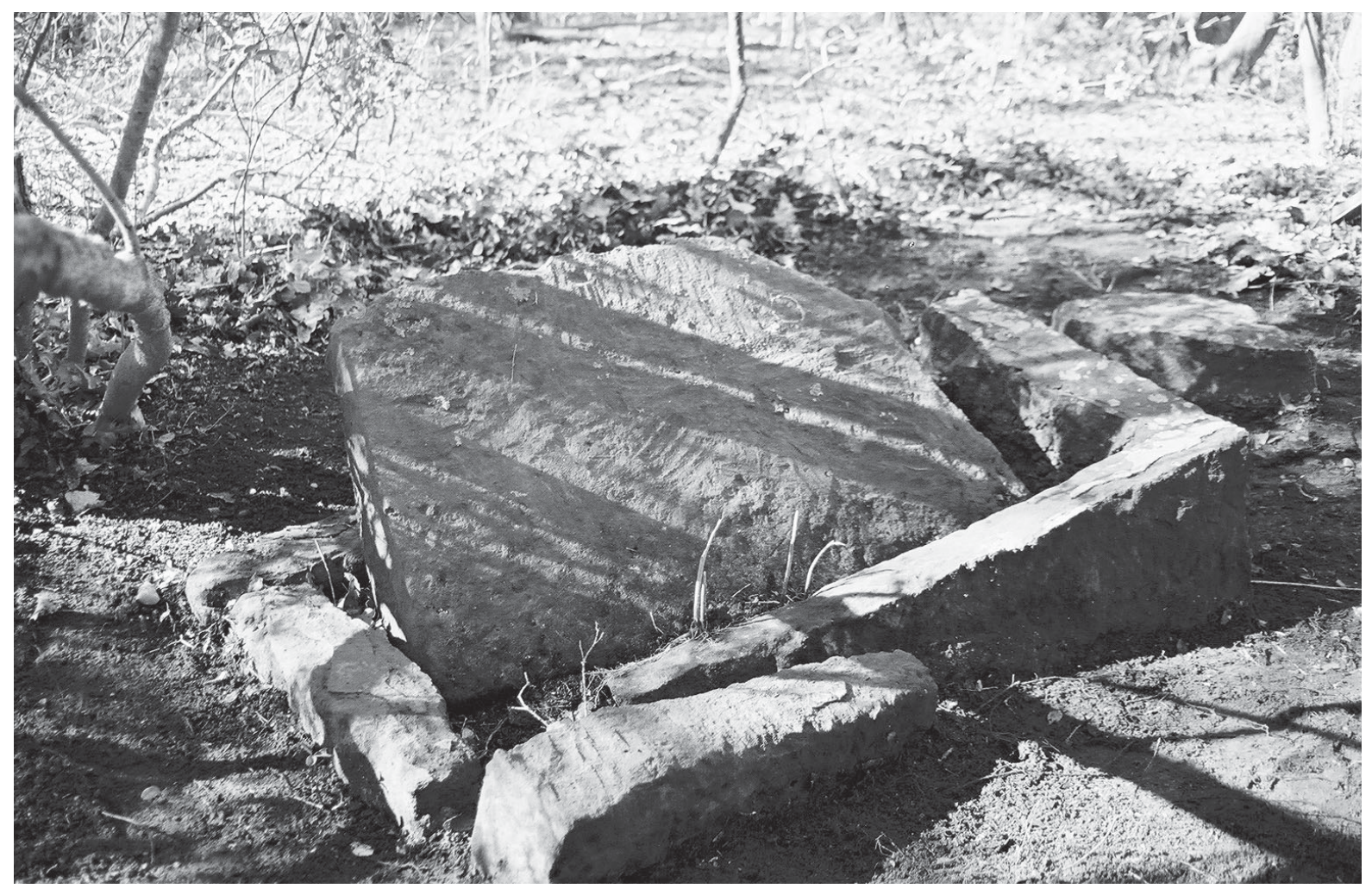

Figure 4-64. Carved sandstone lining the grave.

FIGURE 4-65. REDACTED smoothed. The dimensions of the exterior of the stone lining would have been approximately $261 / 4$ " wide x 53 " long; its interior dimensions would have been 18 1/2" wide $x 47$ 1/2" long. The slab on the north side of the structure had cracked into two pieces and fallen over, causing the cover slab to fall inward. The cover slab was also fractured, with an end piece lying outside the grave enclosure, on its northern edge (Figure 4-66).

Remnants of a rusted and broken barb wire fence run along the western and northern edges of the grave area, with an oak tree measuring ca. 24 inches in diameter 


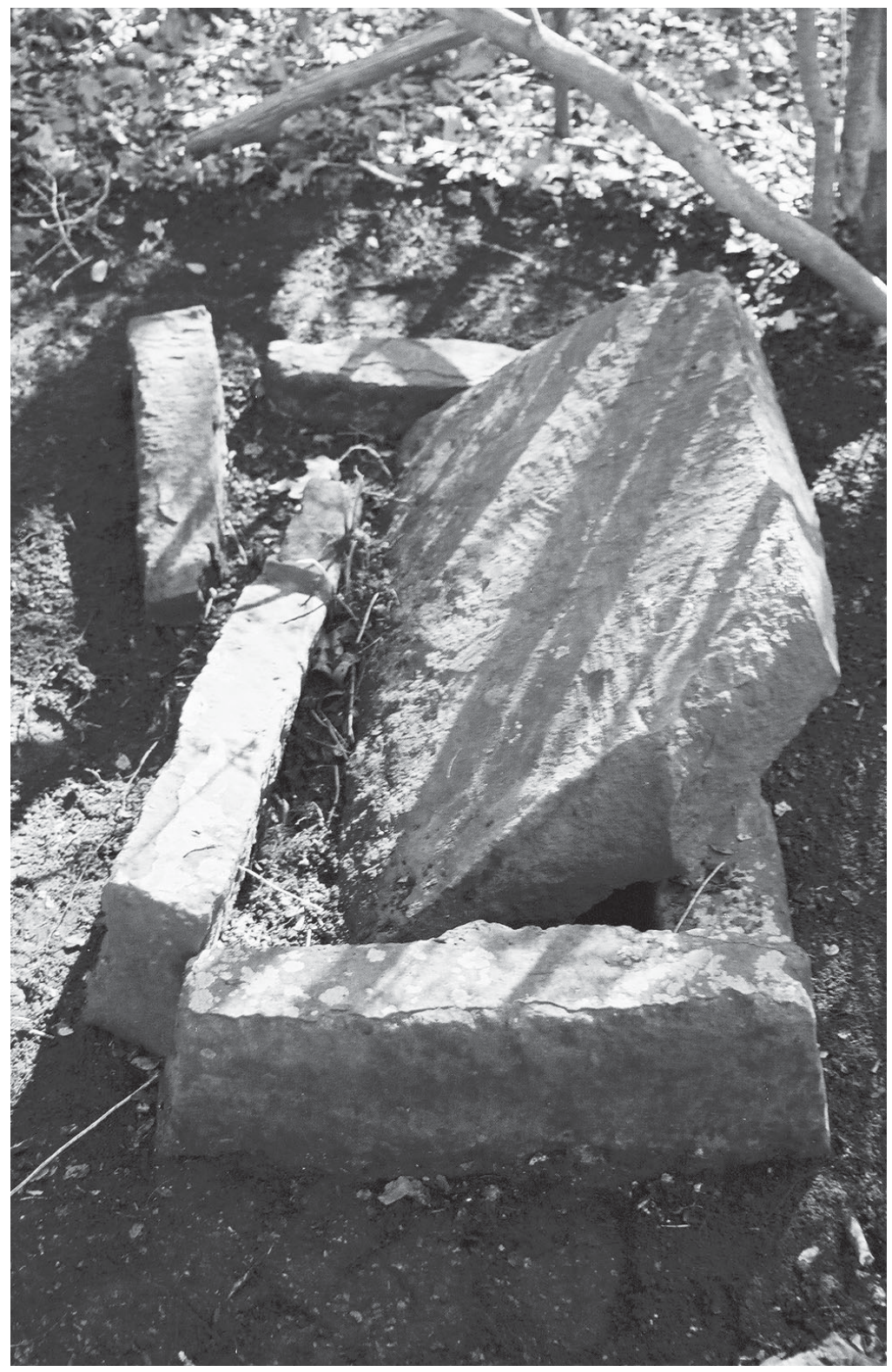

Figure 4-66. Another view of the grave.

serving as a corner post. The tree has grown around the wire so that the wire is now running through the center of the large oak. The barbwire was identified as a two-strand, two-point Glidden's Barb, Common Variation, a variation of Glidden's Winner that was patented in November, 1874 (Clifton 1970:99). Although patented in 1874, barbed wire of this type was not regularly distributed in Texas until after 1878 (McCallum and Owens 1996:377-378).
Archival Research

As stated, Martha Doty Freeman interviewed Ms. Ina Fay Scott in 1978 and 1979, Ms. Scott indicated that she believed the grave was from the era when her husband's grandparents lived in the area (Freeman 1979). Ina Fay's husband was Grover Scott; Grover Scott's parents were John H. Scott and Minnie (Chandler) Scott; Grover Scott's paternal grandparents were Abner and Louisa (Sprenger) Scott. Grandparents Abner and Louisa were married November 10, 1865, and began acquiring land in the area by the following year (Freeman 1979). Therefore, based on Ina Fay Scott's information, we could presume that the grave could date to as early as the period right after the Civil War.

Freeman (1979) surmises that the lone grave at $41 \mathrm{BP} 146$ could be associated with 41BP147, a large farmstead up the slope and to the east. With the help of Ina Fay Scott and archival research, Freeman was able to determine that Otis Evans lived at 41BP147 before WWII. Evans obtained the property from his mother and father-in-law, the Flemings. The Flemings acquired it through a bank procedure from John $\mathrm{H}$. Scott, and when John H. Scott acquired the parcel, it was known as the "Herms" place, although the spelling of the name "Herms" was unsure (Freeman 1979:96).

With the earliest listed as 1850 , there are 20 
Herms, Hermes, or Hearnes listed as grantees in Bastrop County from 1850-1898 (Deed Records Index, Bastrop County, 1837-1920). However, a William Herms is the only one who acquired a large holding within the area of what is now Camp Swift. Additional archival research indicates that the grave is located in Tract D-151, and more specifically on property acquired by William and Johanna Herms from the Corporation of Bastrop.

A man named William Herms (note spelling) came from Prussia and became a naturalized citizen in Bastrop County on May 19, 1853 at the age of 22 (Moore 1977:244). However, a William Herrns (note different spelling) is listed in the 1860 Bastrop County Census as a 39-year old farmer from Germany (Texas Genealogy 2003). Listed in the same family are his 30-year old wife, Wileiheima Herm (note different spelling) also from Germany, his 5-year old son William E. Herm, born in Texas, and 68-year old Johanna Grasis from Germany (possibly Wileiheima's mother?).

Although the relationship is unclear, we have found that the names William Herms (Herrns) and Johanna Herms appear in the early deed transactions for Bastrop County. Over a 19-year period from 1853-1871, William and Johanna acquired their property in four 50-acre tracts (\#s 45-47 and 58 ), and one 30-acre tract (\#59), for a total of 230 acres (see Table 4-24). In all, they held ownership for 28 years, until they sold the entire 230 acres to a John Gest in 1881.

Members of the Gest family (see Table 4-24) held onto the property for 36 years, from 18811917. However, it is unknown whether or not any of the family members lived on the property. We have found that John Gest lived in Fayette County in 1881 , and then by 1917 was living in Lee County

Table 4-24. List of landowners on which the grave at 41BP146 is located.

\begin{tabular}{|c|c|c|c|c|c|}
\hline Date & Obtained from & Granted to & Acres & Cost & Deed Record \\
\hline Sep 23, 1853 & Corporation of Bastrop & Wm. Herms \& wife & 50 & Unk & Book I, Page 107 \\
\hline Feb 15,1862 & Corporation of Bastrop & Wm. Herms \& wife & 50 & Unk & Book M, Page 259 \\
\hline Nov 13,1863 & Corporation of Bastrop & Wm. Herms \& wife & 50 & Unk & Book M, Page 536 \\
\hline Feb 27, 1864 & Corporation of Bastrop & Wm. Herms \& wife & 50 & Unk & Book M, Page 587 \\
\hline Apr 20, 1871 & Corporation of Bastrop & Wm. Herms \& wife & 30 & Unk & Book Q, Page 15 \\
\hline Nov 1,1881 & Wm. \& Johanna Herms & John Gest & 230 & $\$ 1700$ & Book 2, Pages 286-288 \\
\hline Sep 2, 1916 & $\begin{array}{l}\text { John F.C. \& Christianna } \\
\text { Gest }\end{array}$ & Charles Gest (son) & 235 & $\$ 1$ & Book 61, Page 76 \\
\hline Jul 21, 1917 & $\begin{array}{l}\text { Charles (Charlie) Gest } \\
\text { (son) }\end{array}$ & $\begin{array}{l}\text { John F.C. \& Christianna } \\
\text { Gest }\end{array}$ & 235 & $\$ 1$ & Book 63, Page 125 \\
\hline Jul 23, 1917 & $\begin{array}{l}\text { John F.C. \& Christianna } \\
\text { Gest }\end{array}$ & $\begin{array}{l}\text { O. G. Laake (\& Ida M. } \\
\text { [Herms] Bruggerman }\end{array}$ & 235 & $\$ 1000$ & Book 63, Pages 126-127 \\
\hline$? ?$ & $? ?$ & $? ?$ & & $? ?$ & ?? \\
\hline Jan 24,1928 & $\begin{array}{l}\text { John H. \& Minnie L. } \\
\text { Scott }\end{array}$ & $\begin{array}{l}\text { Merchant's \& Farmers } \\
\text { State Bank/Elgin State } \\
\text { Bank }\end{array}$ & 230 & $\$ 2950$ & Book 84, Pages 81-83 \\
\hline Mar 5, 1928 & Elgin State Bank & J. W. Evans & 227 & $\$ 1475$ & Book 84, Pages 81-83 \\
\hline 1929 & J. Evans & $? ?$ & 227 & -- & 1929 Plat Map \\
\hline$? ?$ & $? ?$ & $? ?$ & & $? ?$ & $? ?$ \\
\hline Dec 9, 1939 & $\begin{array}{l}\text { Andrew and Laura } \\
\text { Fleming }\end{array}$ & $\begin{array}{l}\text { J. W. and Willie } \\
\text { (Fleming) Evans }\end{array}$ & 228 & None & Book 102:573-574 \\
\hline Mar 7, 1940 & $\begin{array}{l}\text { J. W. and Willie } \\
\text { (Fleming) Evans }\end{array}$ & Otis \& Oval Evans & 227 & $\$ 860$ & Book 103:171-172 \\
\hline
\end{tabular}


(Bastrop County Deeds and Records [BCDR] Book 2:286-288; Book 63:125-127). His son Charles Gest, lived in Bastrop County in 1917.

On December 5, 1914, Otto G. Laake married Ida M. Bruggerman, the sister of Willie, John, Fred, Walter, Bruno, and Leo Herms (BCDR Volume 101:312; Book L:12). John and Christianna Gest then sold the property to Otto G. Laake in 1917, and it is at this point that we were unable to find any record of the property until 1928. On January 24, 1928, after assigning the parcel as collateral for a $\$ 2,950$ loan, but for non-payment, John H. and Minnie L. Scott were forced to convey the property to the Elgin State Bank (BCDR 84:8183).

The property was auctioned at the Bastrop County courthouse, and on March 5, 1928, J. W. Evans paid \$1,475 for 227 acres (instead of 230 probably a new survey). A 1929 plat map of Bastrop County lists J. Owens as the owner (Bastrop County 1929). Unfortunately, it is here that we once again could find no record of ownership for the years between 1930-1938. However, it appears the property changed hands among relatives because in 1939 we found the following affidavit connecting the Evans' and Flemings' names to the property:

"[whereas]...J.H. Fleming and Willie Evans are the only surviving children of Andrew Fleming (now deceased [died December 7, 1939]) and Laura Fleming (now deceased [died December 2, 1933)...both died in Bastrop County...” “... many years before his death Andrew Fleming made his home with his grandson Odis A. Evans in the town of McDade, Texas and where he died and was buried." "That at the time of his death, Andrew Fleming left a small estate consisting of approximately 228 acres of land..." “...J. H. Fleming and Willie Evans... are now the legal owners of his estate, and as such are legally entitled to convey the same in fee simple as their property." Willie Evans was actually Mrs. J. W. Evans at the time.

Otis and OvalEvans then officially were deeded ownership to the property in March 1940, and held it until it was taken by the U.S. Government for the development of Camp Swift.

\section{Discussion}

The ownership of the property on which the grave is located has a history of passing among relatives. It appears that the earlier owners, the Herms, the Gests, and the Laakes were all somehow related. The later owners, at least the Flemings and the Evans were also related. For example, as discussed above, Ida Herms was married to Otto G. Laake, and Willie Fleming was married to J. W. Evans. An additional document linking the Herms and Gests, and dated April 10, 1917, was also found:

"I, William Hermes, a resident of Bastrop County, reposing special confidence in my beloved sister-in-law, Mary Gest, do hereby transfer my parental authority to and over my infant son, Leo Hermes, who is 5 months old unto the said Mary Gest, she to have the care and custody of the said Leo Hermes until he shall become of age, the said Mary Gest to treat him with kindness and send Leo to school and show him the same care and attention which she would one of her own children" (BCDR 69:367).

Apparently, Mary Gest took good care of young Leo C. Herms because a ca. 1938 Bastrop newspaper's "Roll of Honor" featured a photograph of him as a soldier serving in the U.S. Army Radio Intelligence Division at Fort Sam Houston (Herms 1938).

We have discovered that William Herms was 
39 years old in 1860 , yet as discussed in the previous affidavit, we found a William Herms transferring parental authority on his five-month old son. If this William is the same William who was 39 in 1860, by 1917 he would have been around 96 years old when he fathered Leo! Therefore, without further genealogical research, we assume that the William who signed the affidavit is William Jr. But, the important point here is that the Gests and Herms were related, and a Herms child is being cared for by a member of the Gest family; and both families successively owned the property where the grave is located through July 1917.

Otto G. and Ida M. (Bruggerman-Herms) Laake still held property in the area when Camp Swift was developed; they conveyed 50 acres in Bastrop Town Tract, Lot \#7 to Camp Swift on November 24, 1942 (BCDR 109:272).

\section{How Old is the Grave and who is Buried in it?}

Unfortunately, we are not able to specifically answer that question, but limited archival research and an examination of the gravestones have provided some corroborating evidence. The physical evidence suggests that the grave dates to

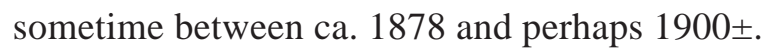
The sandstone slabs at the grave are very similar in workmanship to that of Antoine Aussiloux, who did this kind of craft beginning in 1875, and is known to have continued with the craft into the 1880s. As discussed above (41BP138), Aussiloux's excellent craftsmanship with hand-hewn stone can be seen at his house remains, and at the Scott Falls Dam, those works being done ca. 1875 and 1886 , respectively. He is also credited with hand carving the sandstone rock enclosure around three graves in the nearby Wayside Cemetery around 1883 (Smith and Parnell 1984:12). Aussiloux lived just 1.2 miles northeast of the grave, along Scott Falls Road. Aussiloux died in 1924.

Unfortunately, the sandstone slabs at the 41BP146 grave are not marked with either a date or name, and no apparent grave offerings were observed at the site. The only "artifact" that surrounds the gravestones on two sides is a barbed wire fence that certainly post-dates November 1874, but most probably 1878 .

The small size of the grave strongly suggests that an infant or young child is buried there. Our archival research indicates that three families, the Herms, the Gests, and the Laakes owned the property for the longest contiguous periods (1853$1917+$ ), that these periods encompass the period

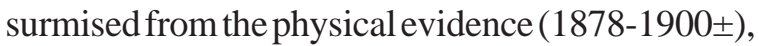
that both families were related to each other, and that at least one infant was transferred from one family to the other by parental consent. By inference, the circumstantial evidence suggests that an infant or small child belonging to the Herms, Gest, or Laake family is buried in the grave.

Problematic with conducting a thorough research of birth and death records for Bastrop County is that by state law, counties were not required to keep them until 1903. Otherwise, such records are sometimes found in family Bibles or other personal records. Therefore, we found only two records of death that may be associated with the grave at 41BP146, and for which we could not find their names in available established cemetery listings. We caveat this in that, while we were able to review the names of burials in cemeteries listed on the Bastrop County website, we were not able to visit cemeteries whose listings were not on the website:

1) Baby Fleming, female, born in America, white, died at age 15 months at Pleasant Grove of 
membranous croup, W.E. Wood, M.D. officiating, Elgin, Texas, October 31, 1903 (Bastrop County Death Records, 3:52)

2) Louise Laake, white, died near Bastrop at age 2 weeks, Coroner/Doctor E.F. Hosler officiating, August 4, 1913 (Bastrop County Death Records, 1:98)

\section{Conclusions/Recommendations}

In order to properly identify the remains, and in depth archival research with potential descendants should be conducted, possibly followed by scientific testing. In the near term, the presumably isolated grave at 41BP146 should be protected with a wellconstructed chain link fence and placed off limits to any type of military training or potentially threatening activities. Because of its location near the edges and confluence of a major drainage and a deeply incised tributary, consideration should be given to relocating the skeletal remains and sandstone slabs. In addition, carefully executed exploratory subsurface investigations for additional burials should be conducted.

\section{$41 B P 148$}

\section{Background}

The abandoned Sayers Mine complex consists of a railroad bed, spoil piles, artifact scatters representing a company store and residences, a cemetery (41BP170), roads, and presumably many abandoned shafts (Figure 4-67). The history of the mine has been aptly discussed in various sources (e.g., Freeman 1979; Leffler 2001; Robinson 2001a, b), and thus only a synthesis of that research will be presented here.

The Sayers Mine was opened by Frank L. Dennison in 1914 (or 1915) to mine lignite, a low grade of coal. His 25-year lease agreement with landowner Mary C. Young allowed him to con- struct engine and boiler rooms, a tipple, commissary buildings, and housing for his employees (Bastrop County Deed Records, Book 56, page 399). He also was able to obtain an easement to build a railroad spur a little over two miles from the southwest (Robinson 2001b).

Originally, miners recruited from Mexico worked the lignite deposits as a slope mine; that is, they simply followed the slope of the lignite deposits into the ground. Carts on rails were either pushed by hand or drawn by mule out of the mine, then up along a sloping wooden tipple with rails. At the end of the tipple, the bodies of the carts were tipped on their sides, spilling the lignite into MK\&T (Missouri, Kansas \& Texas) railroad cars parked on the railroad bed below (Figure 4-68)

After a fire closed the slope mine in 1924, Dennison's workers excavated a shaft to new lignite deposits, and built an upright tipple to vertically hoist lignite from below (Figure 4-69). This apparently worked well until another mine fire in 1928 forced the mine to close for good. Following this second closing, all equipment and buildings were removed (Robinson 2001b).

\section{Description}

The raised rail bed, and nearby spoil piles are overgrown with trees and thorny brush, and the residential area is now covered with dense stands of prickly pear cacti, weeds, tall grasses, post oak, and mesquite. Numerous slump ponds with brackish water now depict the extent of collapsed underground shafts. Traces of narrow-track roads through the residential area are barely visible. Although the mining area is within the upper reaches of active rifle ranges, the cemetery (41BP170) has been declared "off limits" and is surrounded by a chainlink fence. 
FIGURE 4-67. REDACTED

Figure 4-67. Aerial photograph of the Sayers Mine complex.

\section{Levels ofEffort and Results}

According to the Texas ATLAS site report on file at TARL, when Martha Doty Freeman visited the site in 1979, she observed pits, scattered chunks of lignite, 2 white sherds, building stones, wrought iron, miscellaneous metal artifacts and pieces of scrap, 20th century brick, some of which possibly represented machinery footings, concrete conglomerate, and a rubber shoe heel.

When Robinson and others (2001b) attempted to revisit the site in 1997, they were hampered by dense vegetation, and could not relocate it. How- ever, Robinson returned to the site in 1999 with four local informants, drew a sketch map, and photographed areas of the site. Notably, he observed many of the same artifacts as Freeman did 20 years earlier (Freeman 1979; Robinson 2001b).

Railbed, Spoil Piles, and Associated Artifacts

In 2003, CAS archaeologists returned to the area to collect additional artifact data, but most importantly to determine the locations of activity areas using a GPS. Entering the railbed from the western edge of the Camp (see Figure 4-67), we 


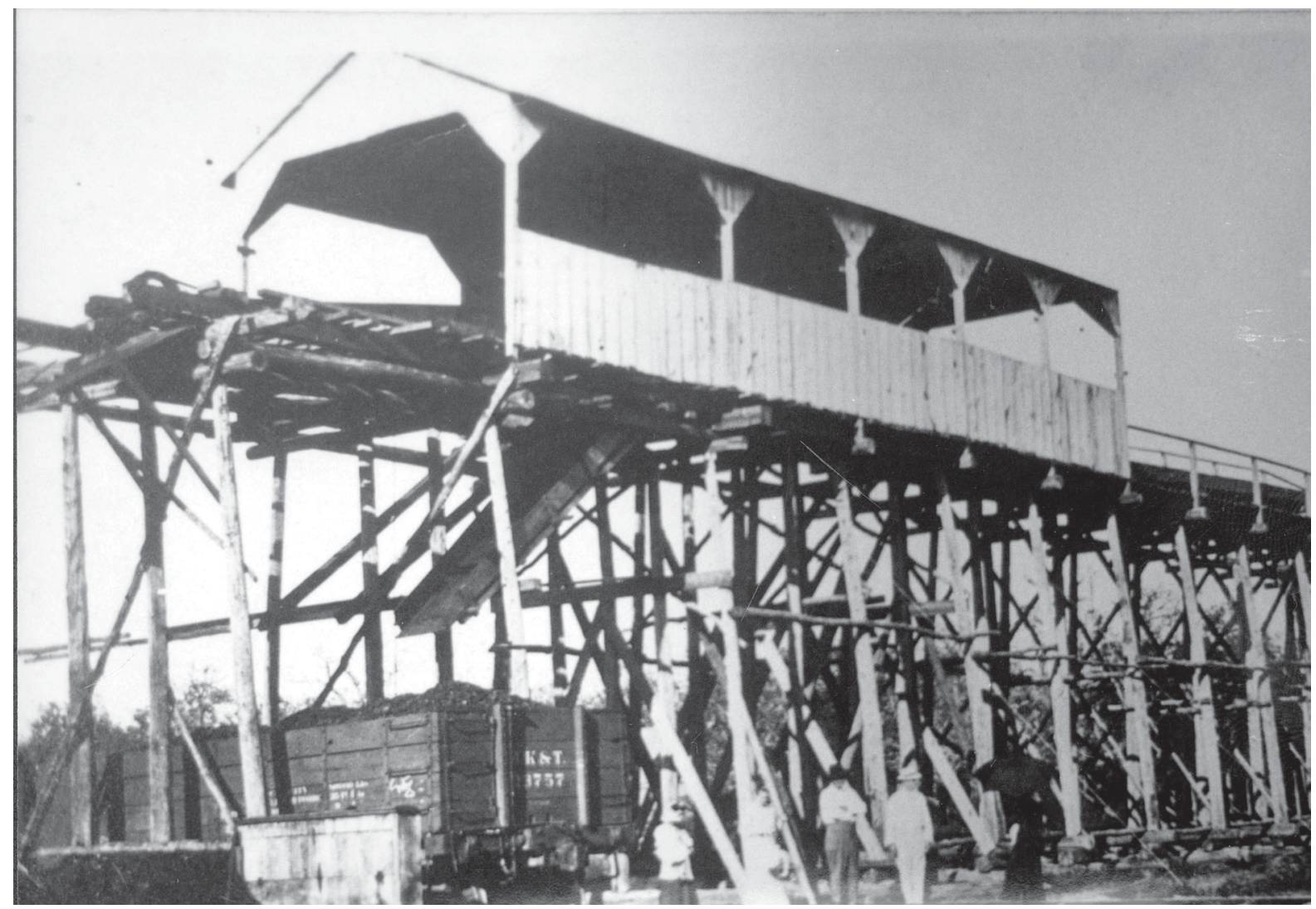

Figure 4-68. Graded tipple leading from slope mine in operation from 1914-1924. Lignite from the mine carts was dumped into MK\&T railcars for transport to the main line 21/2 miles southwest. (Photograph from the Camp Swift historical files, AGTX-EV, Camp Mabry, Austin).

followed it for $990 \mathrm{~m}$ to the location of spoil piles and scattered artifacts on its south edge. Some areas of the railbed along the 990-m stretch were overgrown with trees and brush, and a few areas had been eroded away; however, for the most part, the old railbed was clearly visible and not difficult to follow.

A brush and vine-covered spoil pile ranging in height from one to four feet, and 20 to 28 feet wide runs continuously along the south side of the railbed for 215 feet (Figure 4-70). Robinson (2001:10) describes the content of the spoil piles as "“"...light tan to light gray shale or mudstone...chalky..., and thinly laminated." Although the area is overgrown with thick brush, CAS archaeologists observed several artifacts on the surface; they are listed in
Table 4-25, and selected items are described below.

Near the eastern end of the spoil pile the railbed is no longer raised, and it appears to end at that point. However, an extension of the railbed is manifested by an "opening" the same width as the railbed through the larger trees lining the route. We traced this route through the trees, and to one of the larger slump ponds in the area at the edge of the treeline (see Figure 4-67 and 4-73).

\section{Housing Area Artifacts and Construction Materials}

Proceeding south from the railbed, we encountered several artifact concentration areas with household and construction items that represent the 


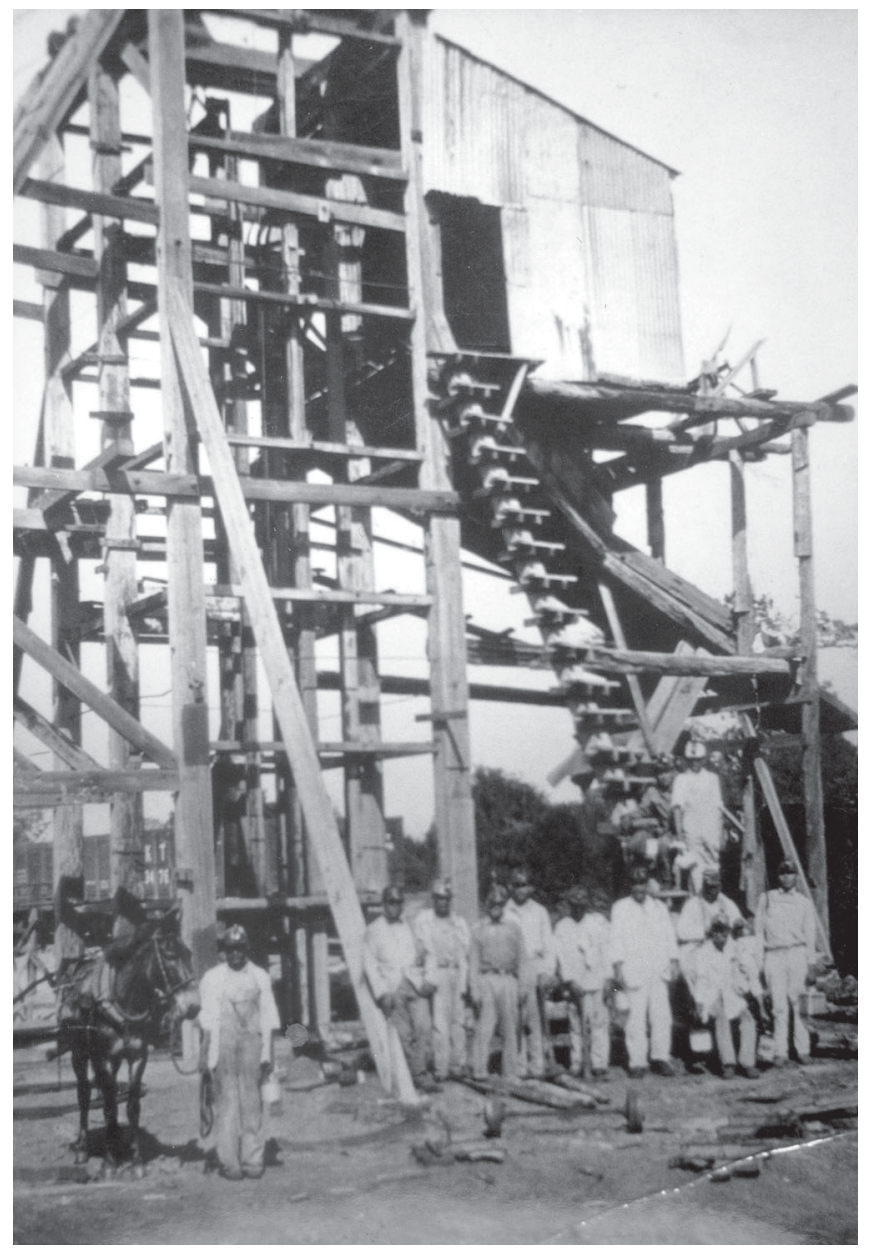

Figure 4-69. This upright tipple constructed over a vertical shaft was used from 1924-1928 to hoist lignite from below. (Photograph from the Camp Swift historical files, AGTX-EV, Camp Mabry, Austin). remains of wooden shacks constructed for the Mexican mine workers. Although we identified nine separate areas, some are more distinct than others. There may be more than nine, but dense grasses, brush, and prickly pear patches obscure surface visibility in the area (Figure 4-74). Additionally, narrow and shallow road depressions could be traced through the housing area (see Figures 4-67 and 4-75). Table 4-26 provides an inventory of items observed in 2003, and selected items are shown in Figures 4-76 and 4-77.

\section{Road to Mexican Cemetery}

A cemetery (41BP170) documented by Freeman (1979) and Robinson et al. (2001) has been determined to be the site where deceased workers and possibly family members of Mexican mine workers are buried. The cemetery lies approximately $290 \mathrm{~m}$ southwest of the housing area (Figure 4-67). Presuming that there would have been a road between the cemetery and the housing area, CAS archaeologists surveyed the area for evidence of such a road. We found two roads; one is a bladed, but somewhat overgrown road cut by the military, and leading

Table 4-25. Surface inventory of spoil pile area adjacent to the railbed.

\begin{tabular}{|l|l|l|l|}
\hline \multicolumn{1}{|c|}{ Household } & \multicolumn{1}{c|}{ Construction } & \multicolumn{1}{c|}{ Industrial } & Transportation \\
\hline Brown glass bottle w/screw top & Paint can lid & 3 metal barrel hoops & License plate \\
\hline Brown glass bottle sherd & Aqua glass insulator & 1 metal brace (6") & Oil filter \\
\hline Clear glass bottle sherd & 6 yellow bricks & Metal, 2-gallon bucket & \\
\hline Tin wash basin & 1 cut sandstone & & \\
\hline Brown "Purex" bleach bottle & & & \\
\hline WW bowl w/embossed design & & & \\
\hline Clear glass bottle neck & & & \\
\hline Clear glass syrup bottle & & & \\
\hline Bedsprings & & & \\
\hline
\end{tabular}




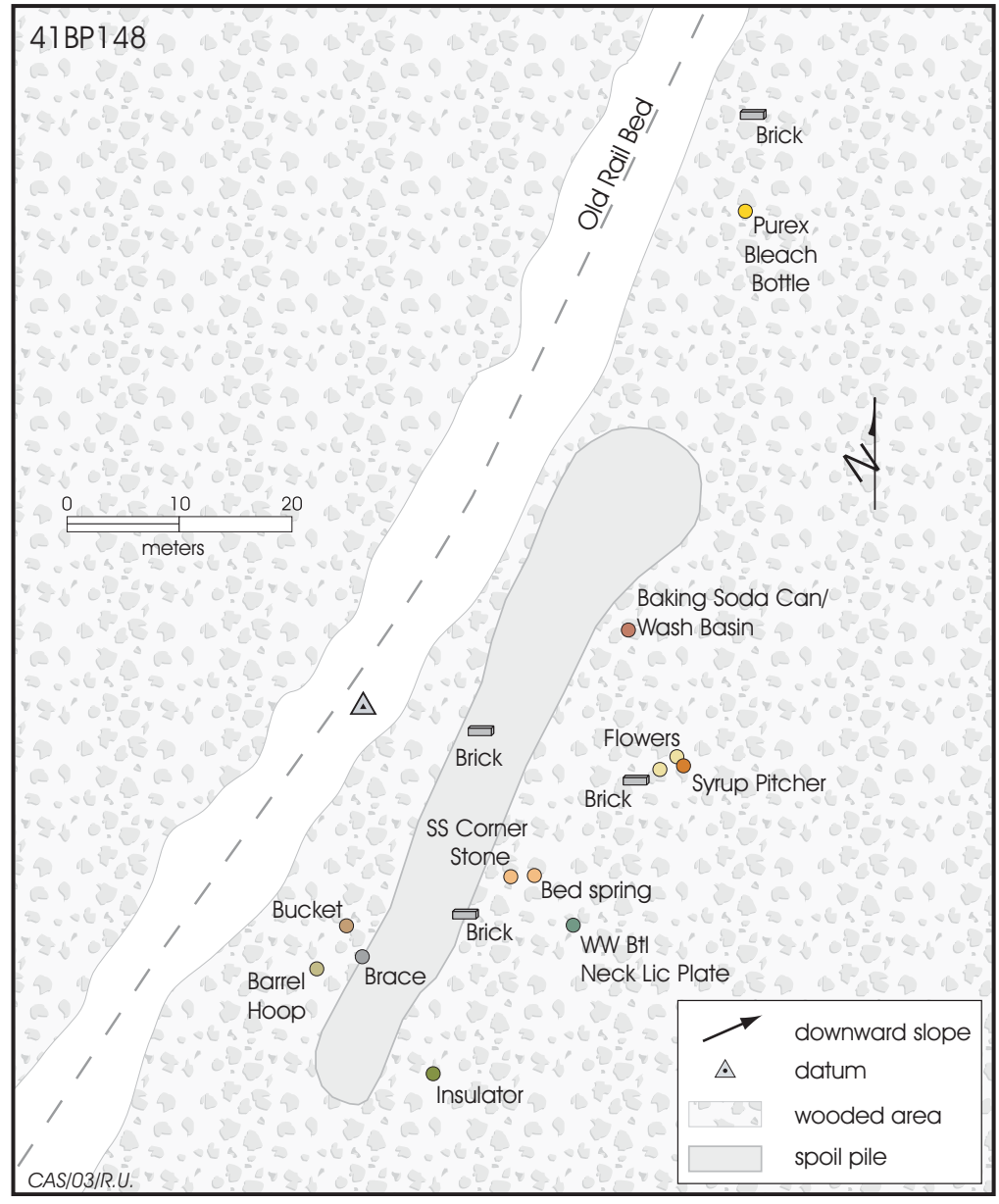

Figure 4-70. Map of spoil pile area with concentration of artifacts alongside the railbed.

directly to the corner of the recently installed chainlink fence surrounding the cemetery; judging from the mature trees within its path, the second appears to be much older, and is narrower. Its course is clear from just west of the cemetery, north to Impact Road, and across Impact Road for approximately another $150 \mathrm{~m}$. Beyond that, the vegetation becomes much more dense, erosion has apparently obliterated much of it, and we could no longer trace its course (see Figure 4-67).

Conclusions/Recommendations

During this project, we were unable to pinpoint the location of the commissary (see Leffler 2001:20). The railbed was followed to an area where there are large spoil piles, and artifacts that are predominately categorized as household in nature, suggesting that such an activity or structure existed there. Perhaps it was either the location of the commissary, or another residence. The location of the housing area was located by artifact and construction material concentrations, and old roads.

Components of the operation include:

1) $41 \mathrm{BP} 148$ - railbed, spoil piles and associated artifact scat-

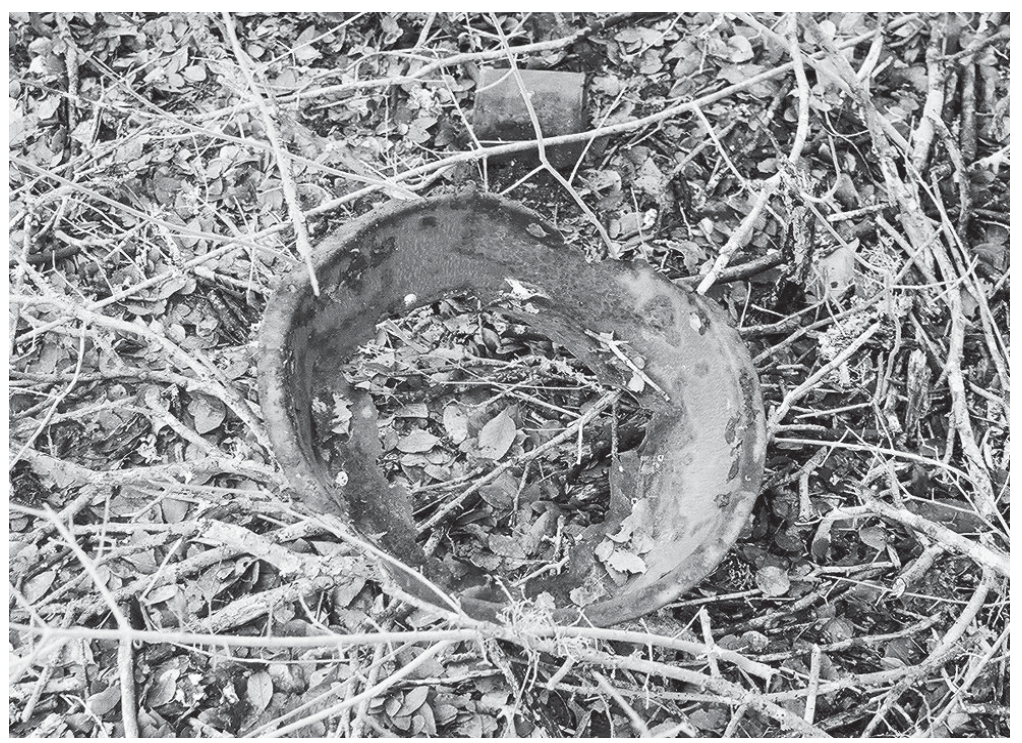

Figure 4-71. A wash basin and brick were found near the railbed and spoil piles, along with numerous other artifacts. 


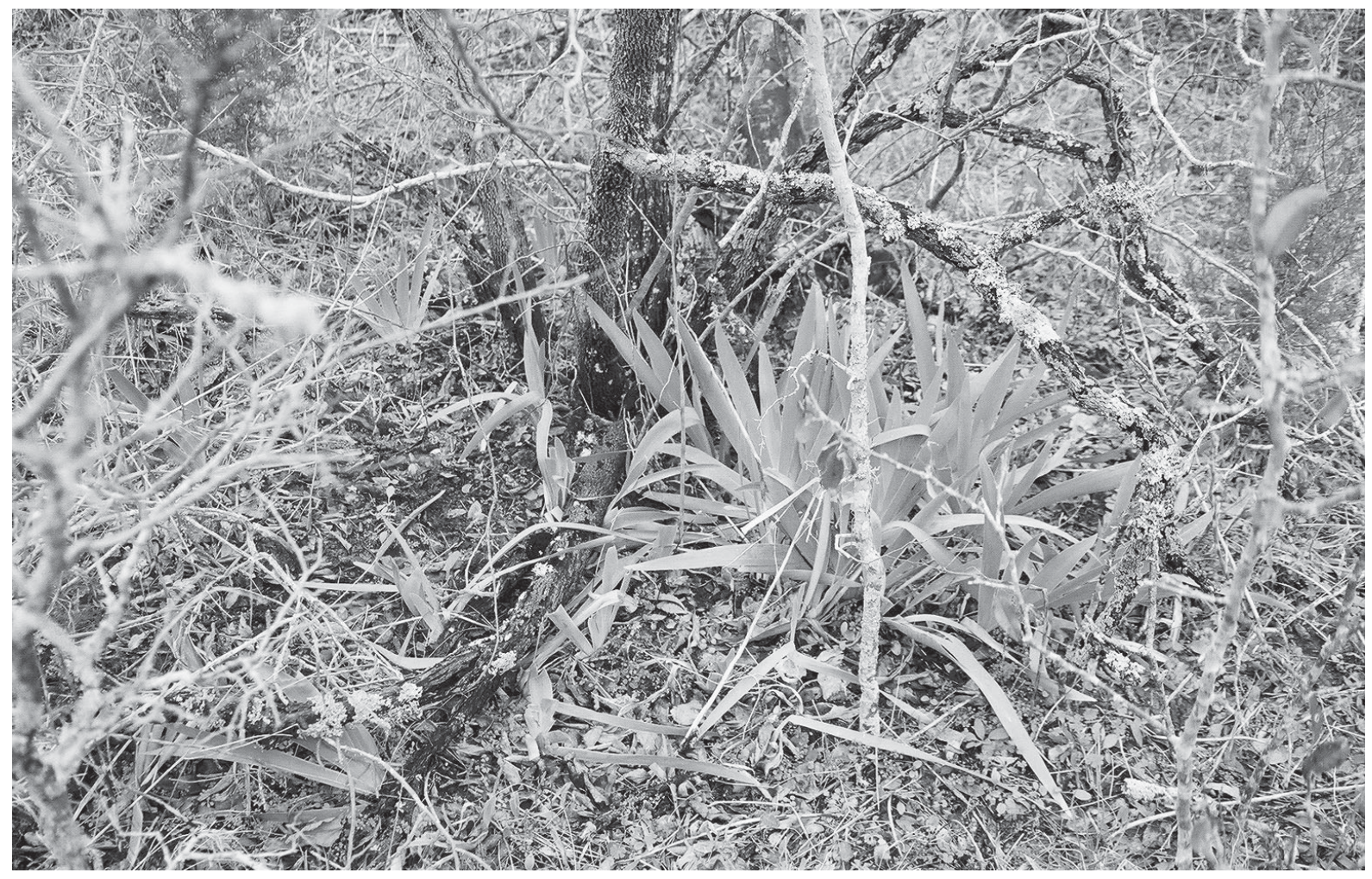

Figure 4-72. Lilies were growing in an area near the railbed, waste piles, and concentration of glass and metal artifacts.

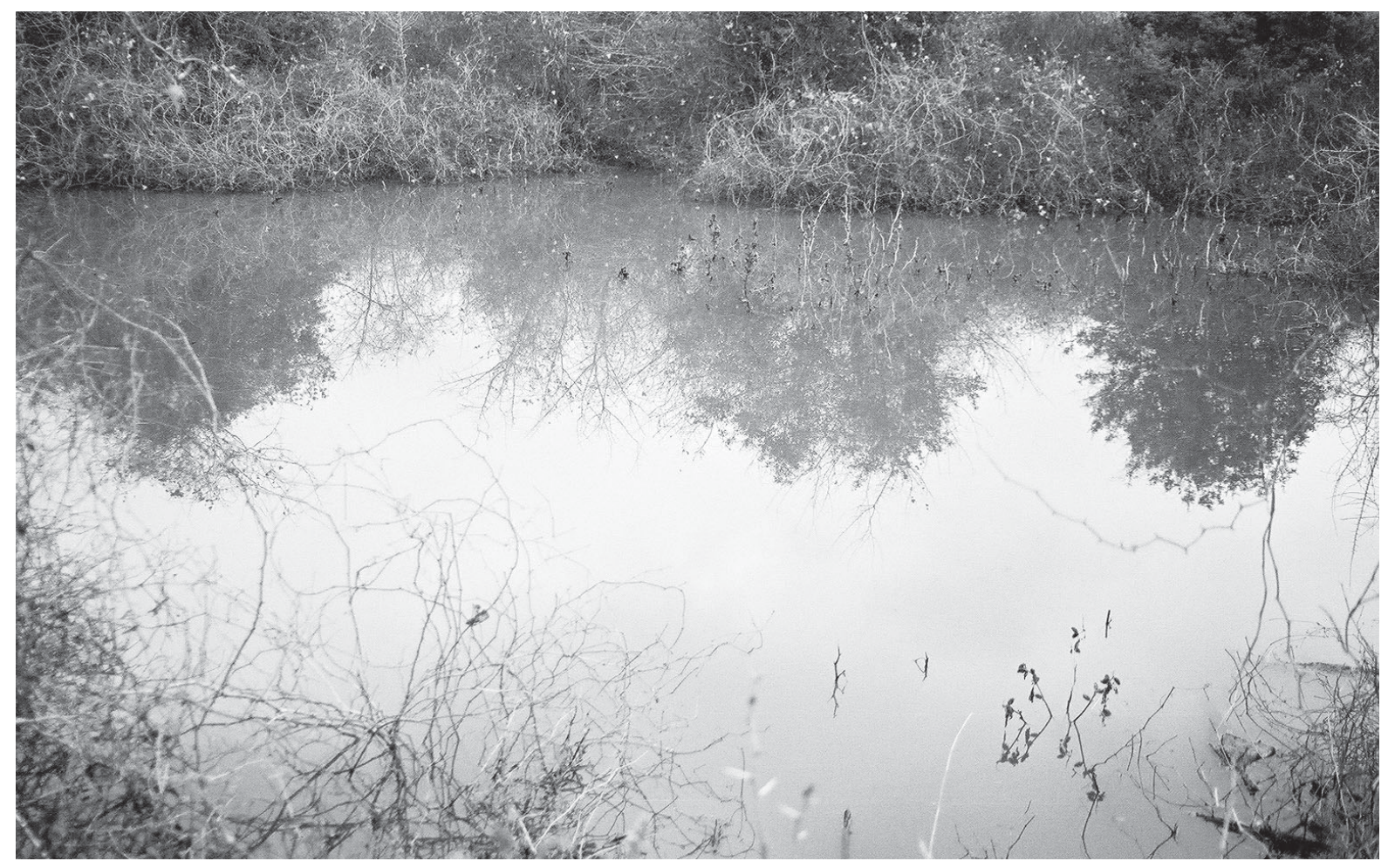

Figure 4-73. This slump pond at the end of the railroad bed is typical of many in the area. 


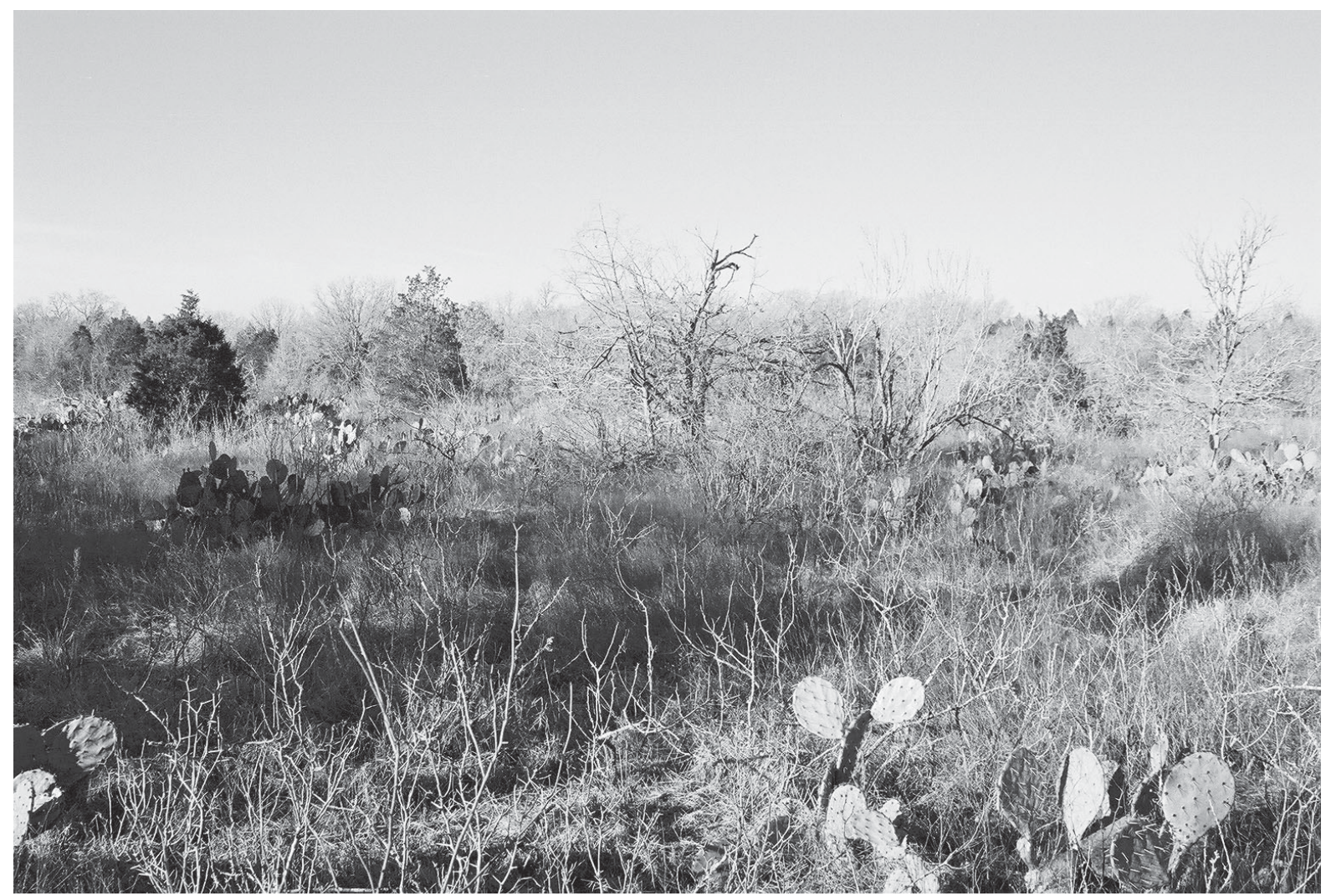

Figure 4-74. Concentrations of artifacts commonly associated with households were found in this area, which is the probable residence area for Mexican workers at the mine; facing east.

ters, housing area with associated artifact and construction material concentration areas, roads

2) $41 \mathrm{BP} 170$ - "Mexican" cemetery with at least 13 burials (possibly more), road

As synthesized here, and as discussed elsewhere(e.g., Freeman 1979; Mauldin 2001; Robinson 2001b;), 41BP170 is significant and should continue to be protected. However, at 41BP148 the mine equipment and rails have been removed, and the houses have been destroyed. Although the operation was significant to the Camp Swift area, it does not meet Criterion A and D significance standards.

Therefore, we assess the components of the Sayersville Mine operation listed above as ineligible for nomination to the National Register of Historic Places.

\section{BP430}

\section{Description}

41BP430 (Figures 4-78 and 4-79) is a historic farmstead covering approximately $15,000 \mathrm{~m}^{2}$, before it was taken over by the military during WWII. A small prehistoric component was also discovered on the site (see Section I for a discussion of the prehistoric component). It is situated on and around a small hill ranging in elevation from 500-510 feet. There are tall grasses on the hill, surrounded by a moderately dense treeline supported by Axtell fine sandy loam (AfC), and consisting mainly of oak, cedar, pine, and mesquite. The house and any outbuildings that once existed have been bulldozed. A depression marks where the house probably stood. Other evidence of historic occupation in- 
FIGURE 4-75. REDACTED chert flake. Surface finds during their investigation included porcelain fragments, and window glass sherds (not collected). In 2003, CAS-SWT personnel excavated eleven shovel tests and collected 1 brown snuff bottle lip, 32 pieces of clear glass, 2 pieces of brown glass, 2 pieces of ironstone, 1 round nail, 1 metal fragment, 2 pieces of whiteware (one is a rim), and 1 bullet (Table 4-27). A probable bulldozed house depression is located to the east of the jeep road and beyond this, to the east, is an old well covered by mustang grapevines (see Figure 4-79).

The farmstead is located on the David Holderman Headright Survey. David Holderman owned three large parcels in Bastrop County. He was issued a certificate for $3 / 4$ of a league $(4,428$ acres $)$ and 1 labor

Figure 4-75. Map of artifact concentration areas and road traces through the residential area.

cludes large oak trees, a well, and barbwire fencing. A modern jeep road now cuts through the southern edge of the site. Surface visibility was approximately 30 percent.

\section{Levels of Work and Results}

In 1995, Schmidt and Cruse excavated seven shovel tests and found 1 square nail dated ca. late 1800 s, 2 earthenware shards, 2 red brick fragments, 1 amber vessel glass shard, and 1

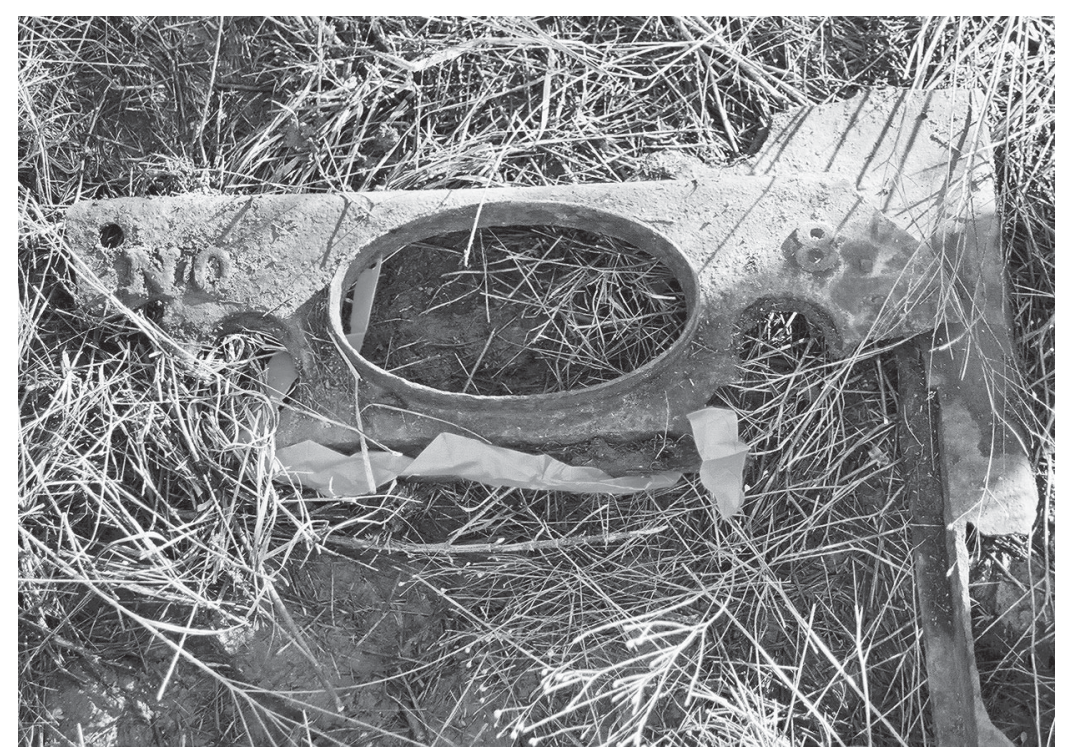

Figure 4-76. Among other household items found in the residence area was this broken stove top from Concentration Area 2. 
Table 4-26. Inventory of artifacts and construction material observed on the surface in the housing area in 2003.

\begin{tabular}{|l|l|}
\hline Area & \multicolumn{1}{|c|}{ Items } \\
\hline 1 & $\begin{array}{l}\text { Two whiteware sherds (1 burned), glazed stoneware rim sherd, metal bucket piece, } \\
\text { large spoon, decorated kitchenware, brown snuff bottle neck, two brown glass bottle } \\
\text { base sherds (refits), red brick fragment, clear glass bottle base, clear glass bottle w/o } \\
\text { upper neck }\end{array}$ \\
\hline 2 & $\begin{array}{l}\text { Laid ironstone pattern, three whiteware sherds, light green bottle glass sherd, "No. 8" } \\
\text { stovetop piece, }\end{array}$ \\
\hline 3 & Hewn ironstone, stove pipe, metal fragments \\
\hline 4 & Mound of hewn ironstone -8 feet x 12 feet x 18 inches high \\
\hline 5 & Mound of hewn ironstone -8 feet x 10 feet x 24 inches high \\
\hline 6 & Six hewn ironstones, thick brown bottle base, whiteware sherd, pinkish/red brick \\
\hline 7 & Three whiteware sherds, \#3 washtub, amethyst bottle glass sherd \\
\hline 8 & Whiteware sherd, two \#3 washtubs \\
\hline 9 & Flat barb wire, \#3 washtub, unidentifiable metal piece \\
\hline
\end{tabular}

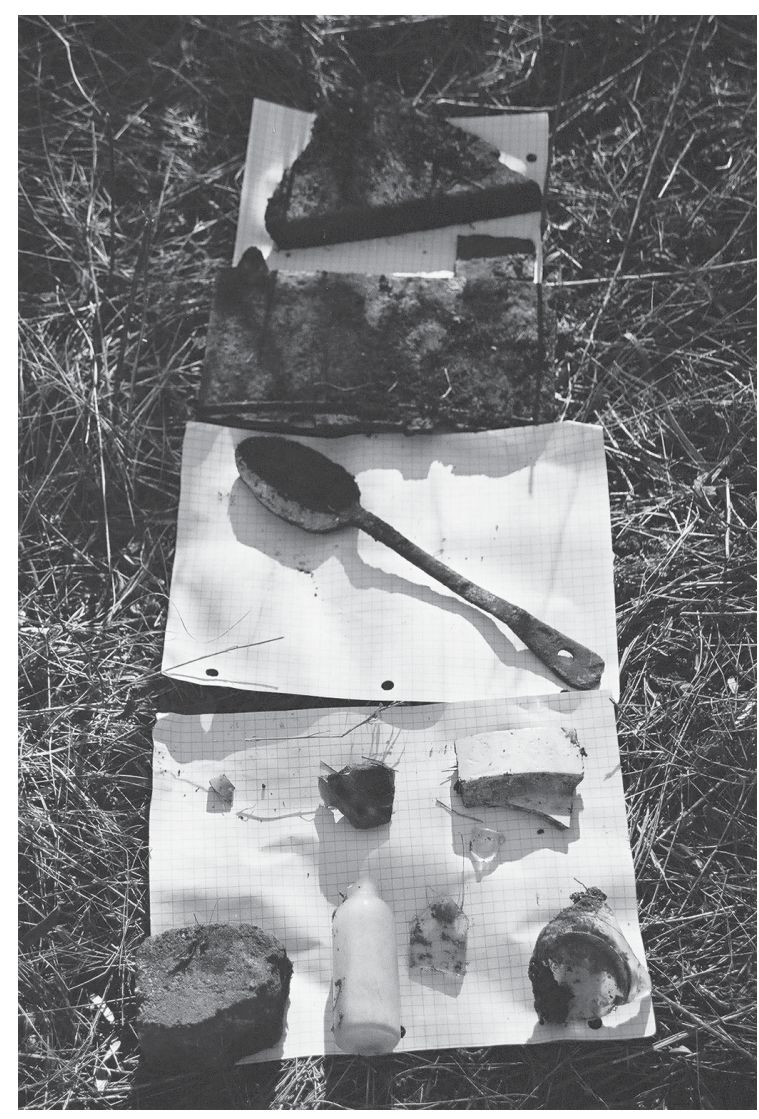

Figure 4-77. A few of the houshold and construction items found in Residence Concentration Area 1 were cut stone, a metal bucket piece, a large spoon, decorated kitchenware, a brown snuff bottle neck, a glazed stoneware rim sherd, a red brick, and clear glass bottle sherds.
(177.1 acres) in 1833 by the Land Commissioners of Bastrop County (Moore 1977:255). He was also assigned 1/3 of a league from John James in 1835, as well as $1 / 3$ of a league from a person named $\mathrm{H}$. H. Oats in approximately 1835 (Moore 1977:256, 257). John James was a pioneer surveyor during the Republic of Texas and early years of statehood who, among other ventures, acquired several leagues of land in Texas by "locating, surveying, and perfecting titles to large tracts of land in unsettled areas" (Strong 1996). For his services, he was paid in land certificates. A research of various Texas history sources provided no additional information regarding Mr. Oats. The Town of Mina, the prior name of Bastrop, also granted David Holderman two deeds (Moore 1977:38; Marks 1996:410-411).

Freeman (1979:90) states "It is apparent that at least one of the original patentees actually resided on his grant. David Holderman, immigrant of 1832 (Texas. General Land Office: 1945), was living on 2,725 acres evaluated at $\$ 9,086$ by 1839 . The following year his holdings included 545 acres appraised at \$2,180, 12 Negroes, and 20 cattle." "In 1850, Holderman owned 3,000 acres assessed at $\$ 7,500 \ldots$.. When the Army acquired the property, 


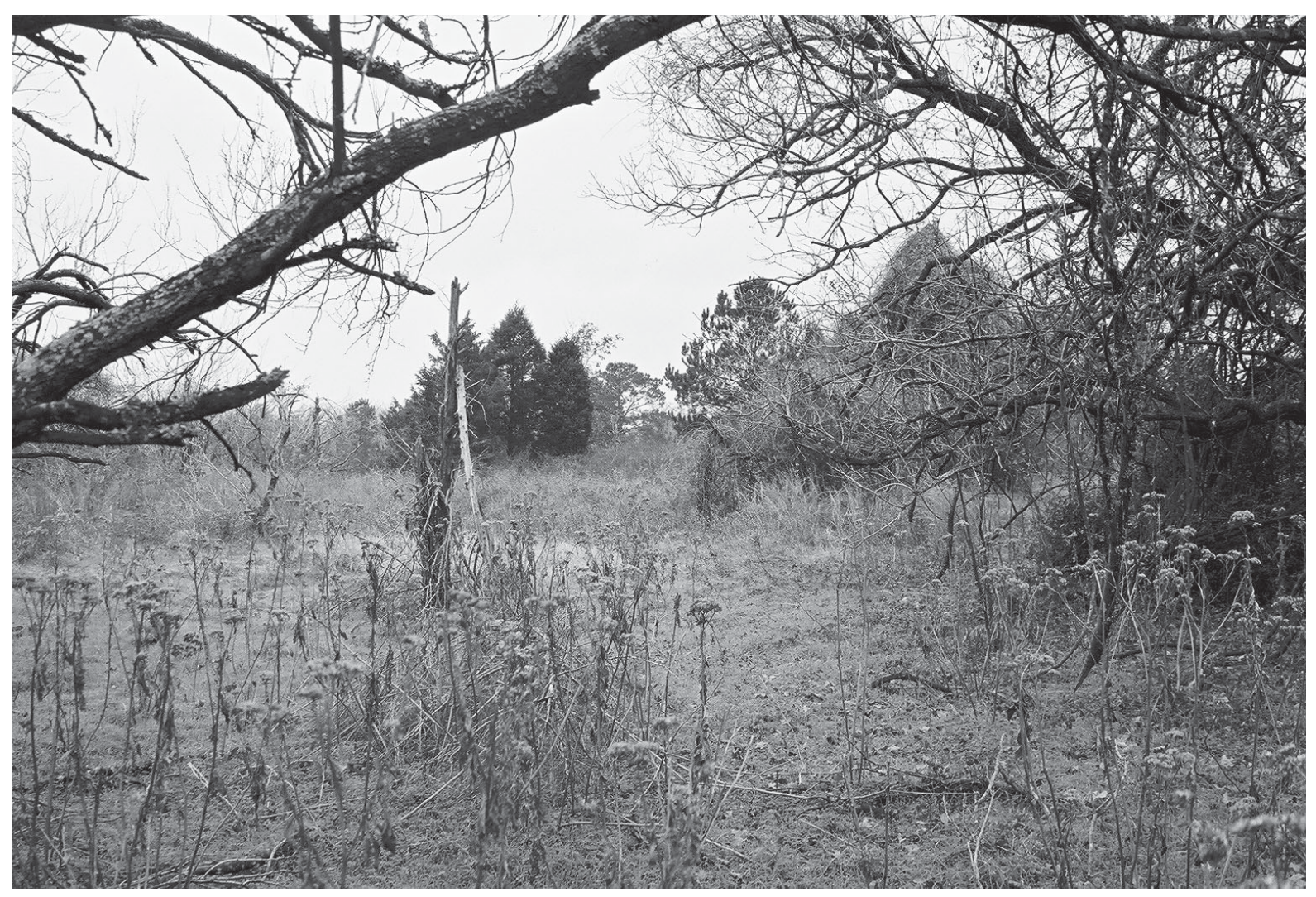

Figure 4-78. All that remains of the farmstead are scattered artifacts, a depression where presumably the house stood, and a stonelined well; facing west.

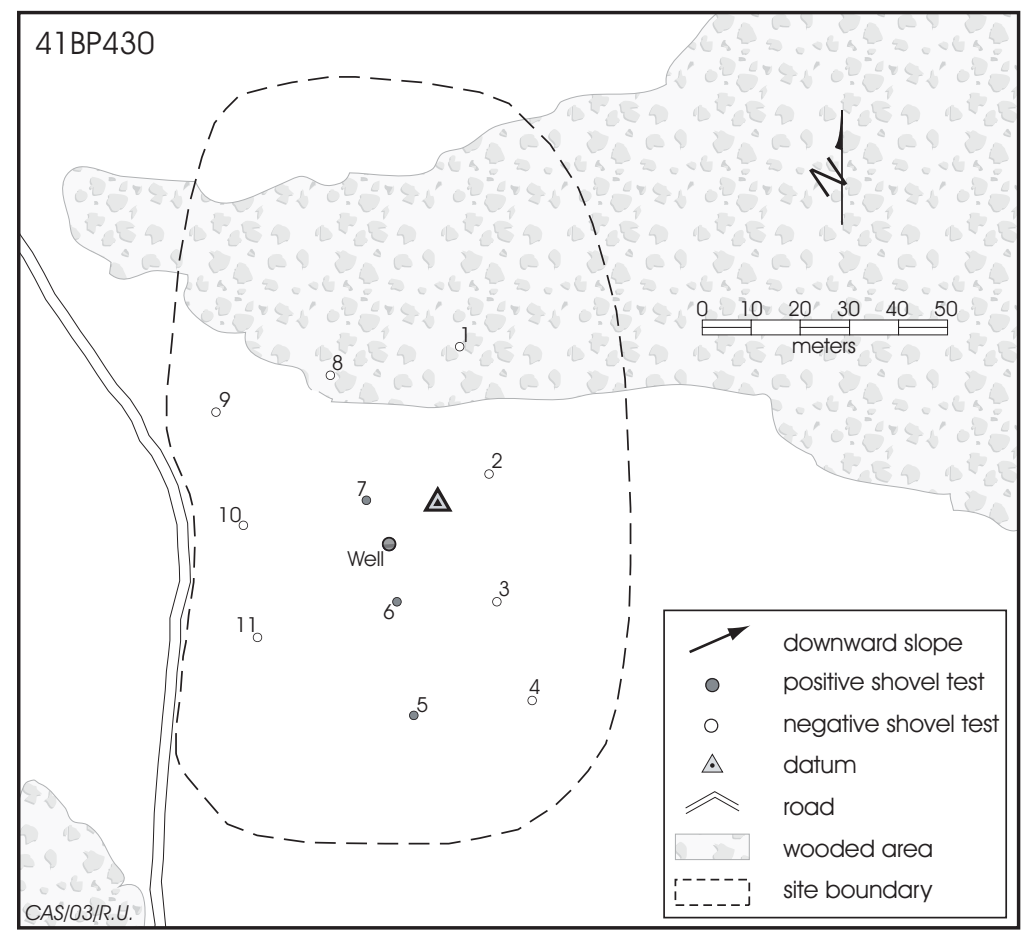

Figure 4-79. Site map, 41BP430. 


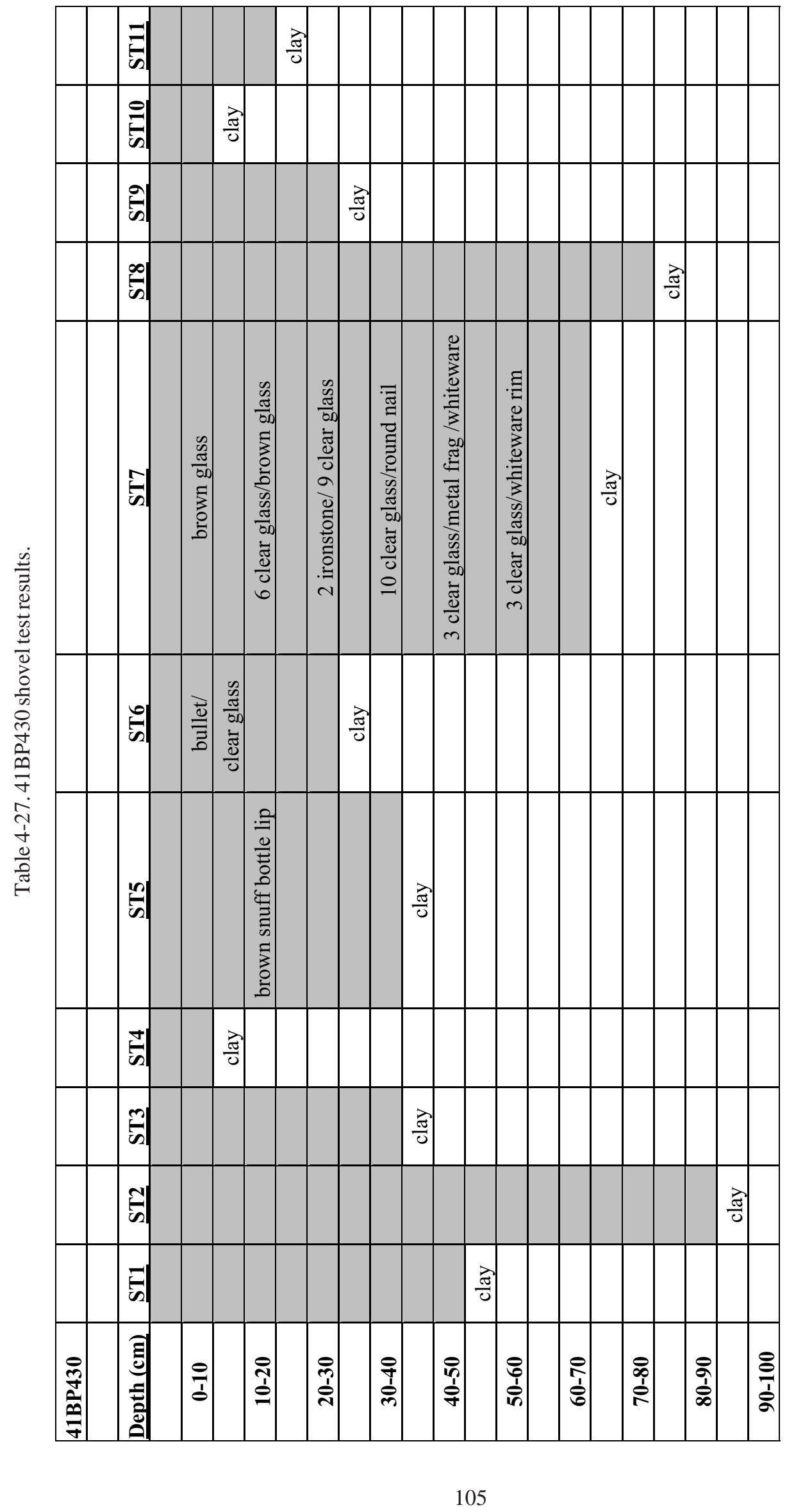


Table 4-28. 41BP430 landowners (from Bastrop County Deed Records).

\begin{tabular}{|l|l|l|l|l|}
\hline Seller & Buyer & Date & Transaction & Deed Record \\
\hline William H. Coulson, Sr. & $\begin{array}{l}\text { Robert W. Morrison \& } \\
\text { David Bird }\end{array}$ & Nov 30, 1882 & 140 acres for \$700 & $\begin{array}{l}\text { Book 3, } \\
\text { Page 504 }\end{array}$ \\
\hline Morrison \& Bird & Isabella Coulson & Feb 4, 1886 & 140 acres for \$650 & $\begin{array}{l}\text { Book 16, } \\
\text { Page 324 }\end{array}$ \\
\hline Isabella Coulson & J.W. Westbrook & Jan 9, 1891 & 140 acres & $\begin{array}{l}\text { Book 16, } \\
\text { Page 537 }\end{array}$ \\
\hline J.W. Westbrook & F.W. \& Francis Weatherford & Oct 24, 1917 & 140 acres & $\begin{array}{l}\text { Book 63, } \\
\text { Page 510 }\end{array}$ \\
\hline Weatherfords & H.C. \& Estella Fleming & Jul 21, 1922 & 140 acres & $\begin{array}{l}\text { Book 74, } \\
\text { Page 229 }\end{array}$ \\
\hline Flemings & S.A. \& Mary Etta Graham & Apr 14, 1923 & 140 acres & $\begin{array}{l}\text { Book 75, } \\
\text { Page 153 }\end{array}$ \\
\hline Grahams & U.S. Government & Aug 14, 1942 & 140 acres & $\begin{array}{l}\text { Declaration of } \\
\text { Taking \#4 }\end{array}$ \\
\hline
\end{tabular}




\title{
Chapter 5
}

\section{Historic Context and Research Design}

\author{
David L. Nickels
}

\section{Introduction}

This chapter is divided into two sections. The first section considers the regional historic context that served as a basis for formulating research issues pertinent to the prehistoric period, while the second section considers the occupation and development of the land that is now Camp Swift during the historic period. Both sections provide the results of shovel testing. However, although the focus of this chapter deals with the results of shovel testing 18 sites during this current project, we also incorporate the results from a project completed at Camp Swift in 2001 during which 38 prehistoric components sites were shovel tested (Nickels et al. 2003) into the overall analysis, and a predictability model of site significance.

\section{Section I: Prehistoric Issues}

Identifying and addressing prehistoric research themes before and during the project provides a framework within which the significance of the cultural resources and data from the project can be evaluated. Projects such as this produce site data that can address geomorphic processes and site integrity. In this regard, we considered several themes. Some could be addressed during this shovel test project, but one is too broad for such a limited project as this one. First, we deal with an issue involving the formation of the sandy mantle, and it is expected that this important issue could be addressed by future investigations on Camp Swift. Second, we address the issues of the potential for buried sites, and site integrity relative to terrain features and soils. Third, we examine the significance evaluations placed upon sites, relative to the types of soils within which they are found.

\section{Formation of the Sandy Mantle}

This research issue was addressed following our work at Camp Swift in 2001, and the reader is referred to Nickels et al. (2003) for a thorough discussion. Therefore we will merely synthesize the discussion for this project. The archaeological potential of the sand sheet, also known as the sandy mantle and informally named the Big Brushy formation, was first recognized by Heinrich (1986) during investigations in east Texas at Jewett Mine. The sandy mantle extends in a slowly expanding pattern from south of San Antonio in a northeasterly direction into east Texas. It closely follows the distribution of the various sandy (argillious) Eocene deposits. The primary issue is whether archaeological sites occur buried in situ within these sandy deposits. As site significance in terms of NRHP eligibility is often directly linked to geological context, this very important matter requires resolution. 
At Camp Swift, one of the three depositional units recognized includes the sandy mantle. Prochnow (2001). The sand sheet and eroded uplands occurs above the lower T0 modern floodplain, and the $\mathrm{T} 1$ terrace/bench four meters above the stream channel (Figure 5-1)

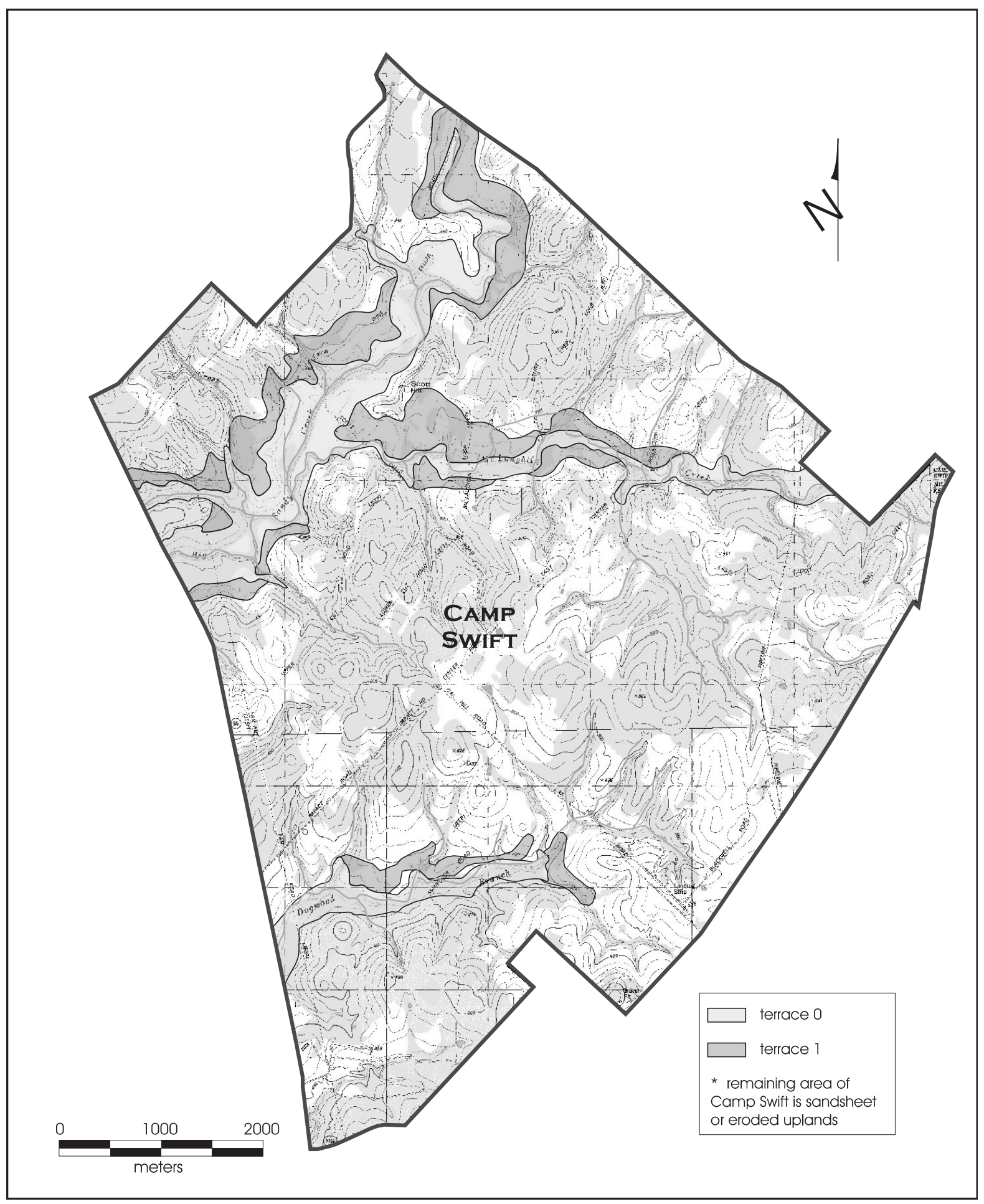

Figure 5-1. Sediment depositional units on Camp Swift (adapted in part from Prochnow 2001). 
The distinction patterns that characterize the sandy mantle and archaeological sites found within the sandy mantle are: 1) The typical soil profile displays an A-E-Bt pedon; 2) The Bt horizon is often red (rubified) and heavily weathered Eocene bedrock; 3) Clay lamella are found within the E and stacked on top of weathered Eocene deposits; 4) The boundary between the $\mathrm{E}$ and $\mathrm{Bt}$ horizons is often abrupt and irregular to wavy; 5) The sandy mantle can vary greatly in thickness $(30-450+\mathrm{cm})$; 6) Eroded gullies occasionally mark the boundary between the $\mathrm{E}$ and $\mathrm{Bt}$ horizons, and these are infilled with E horizon material; 7) Water worn gravels occur in the sandy mantle but not in the $\mathrm{Bt}$ horizons; 8) Cultural materials are found in the sandy mantle but not in the Bt horizons; 9) Hearths and other burned rock features are found in place in the sandy mantles, but not the Bt horizons.

Archaeologists and geoarchaeologists elicit two basic models to explain these patterns. One suggests that the sandy mantle forms through the pedogenic processes of elluviation and illuviation, and the sandy mantle and the underlying clay horizons were created soley by peodogenic processes. Therefore the entire pedon consists of weathered Eocene sediment. If that is the case, then the model proposes that the prehistoric artifacts and other materials are reconstituted downward in profile, and thus the archaeological material is not in situ (Brown 1975; Thoms 1993).

The second model suggests that colluvial (slope wash) and aeolian (wind) depositional processes have buried archaeological material in situ within the sandy mantle (Fields 1987, 1990; Fields et al. 1988; Rogers 1994; Thoms 1993). The proponents of this model argue that these features could not have developed through pedogenic processes.

In a slight twist to the debate, Thoms (1993:73-
78) argues that the sandy mantle slowly moves across the landscape because of gravity and bioturbation, and the Bt horizons form during this process (Waters 1992:301-304). In this model one would expect that upland high points would have thin sandy mantles with well developed Bthorizons.

Although not without its critics (e.g., Bruseth and Martin 2001), one of the latest techniques for attempting to unravel the mystery and prove or disprove these models is Optical Stimulated Luminescence (OSL) dating (Rogers 1994; Rogers and Foster 1994; Ricklis 2001). Other corroborating techniques involve the use of archaeomagnetic analysis of burned rock and magnetic susceptibility of sediments.

\section{Section II: Research Issues Addressed at Camp Swift During this Project}

\section{Depths of the Sandsheet}

\section{Results of Shovel testing}

As with our previous shovel testing project at Camp Swift during which we evaluated 39 sites, we have used the same analytical procedures to evaluate the 18 sites shovel tested during this current project. Therefore, we are able to systematically compare the results from a total of 57 sites.

As with the 2001 project (Nickels et al. 2003), for purposes of our research, we chose to classify site settings based on our personal observations in the field as either: drainageway, ridge, ridge/foot slope, ridge/side slope, ridge/upland, side slope, terrace, or upland. These classifications fit the scheme of mapped soil descriptions given within the Soil Survey of Bastrop County (Baker 1979), and are equivalent to those of Kay and Tomka (2001). Table 5-1 shows the equivalency. 
In order to evaluate the amount of deposition present in different settings on Camp Swift, and thus the potential for intact buried cultural mate-
To evaluate the potential integrity of cultural deposits within the different soil types and settings, we used the computed mean shovel test

Table 5-1. Comparison of site setting categories.

\begin{tabular}{|l|l|l|}
\hline $\begin{array}{l}\text { Site Categories (Robinson } \\
\text { 2001; Kay and Tomka 2001) }\end{array}$ & $\begin{array}{l}\text { Site settings (Robinson 2001; } \\
\text { Kay and Tomka 2001) }\end{array}$ & $\begin{array}{l}\text { Site Categories (this } \\
\text { publication) }\end{array}$ \\
\hline Terraces & Flat areas along stream edges & Terraces \\
\hline Valley Margins & $\begin{array}{l}\text { Shoulder Slopes, Backslopes, } \\
\text { Summits, Knolls }\end{array}$ & $\begin{array}{l}\text { Foot Slopes, Side Slopes, } \\
\text { Drainageways }\end{array}$ \\
\hline Uplands (Upland Divides) & High areas between tributaries & Ridges, Uplands \\
\hline
\end{tabular}

rial, we examined the results of 501 shovel tests conducted on the 39 sites tested during our 2001 project, and 306 shovel tests on 18 sites from this project; Table 5-2 shows the results. (Note that those shovel tests terminated because inflowing water collapsed the sides, or when a hearth was encountered are not included in Table 5-2, nor are they included in the data analysis throughout this chapter). Cryptic characteristics of the soils encountered during testing are synthesized in Table 5-3.

After conducting shovel testing on 39 sites at Camp Swift in 2001, we reported those results and attempted to develop a predictability model for site significance based on the soil types (and by implication, site settings) within the Camp (see Nickels et al. 2003:133-151). depths at each site; Figure 5-2 shows the broad ranges of mean depths for the 39 sites shovel tested in 2001 and the 18 sites tested during this project. The reader is reminded that shovel testing was generally terminated 1) at a standardized 100 $\mathrm{cm}$ (except41BP138) depending on site condition, or 2) occasionally deeper if cultural material was present, or 3) upon reaching the underlying $\mathrm{Bt}$ paleosol at $<100 \mathrm{~cm}$. The implication is that soils present above the Bt paleosol could be much deeper than $100 \mathrm{~cm}$, but in most cases our designed methodology artificially constrained the mean lower ranges of shovel testing to $100 \mathrm{~cm}$ or higher.

As noted in Table 5-3, there are three types of soils that are mapped as unique to a single setting (uplands): Crockett, Patillo, and Silstid. An exami-

Table 5-2. Cryptic characteristics of soils encountered during the 2001 and 2002-3 testing projects.

\begin{tabular}{|l|l|l|}
\hline Soil & Description & Occurs Most Frequently On \\
\hline Axtell Series & Fine sandy loam & Stream terraces and uplands \\
\hline Axtell-Tabor Complex & Sandy loam & Ridges, side slopes, and uplands \\
\hline Crockett Series & Sandy loam & Uplands \\
\hline Demona Series & Loamy fine sand & Ridgetops, side slopes, and drainageways \\
\hline Patillo Series & Sandy & Uplands \\
\hline Sayers & Fine sandy loam & Drainageways \\
\hline Silstid Series & Loamy fine sand & Uplands \\
\hline Tabor Series & Fine sandy loam & Ridgetops, foot slopes, and drainageways \\
\hline
\end{tabular}




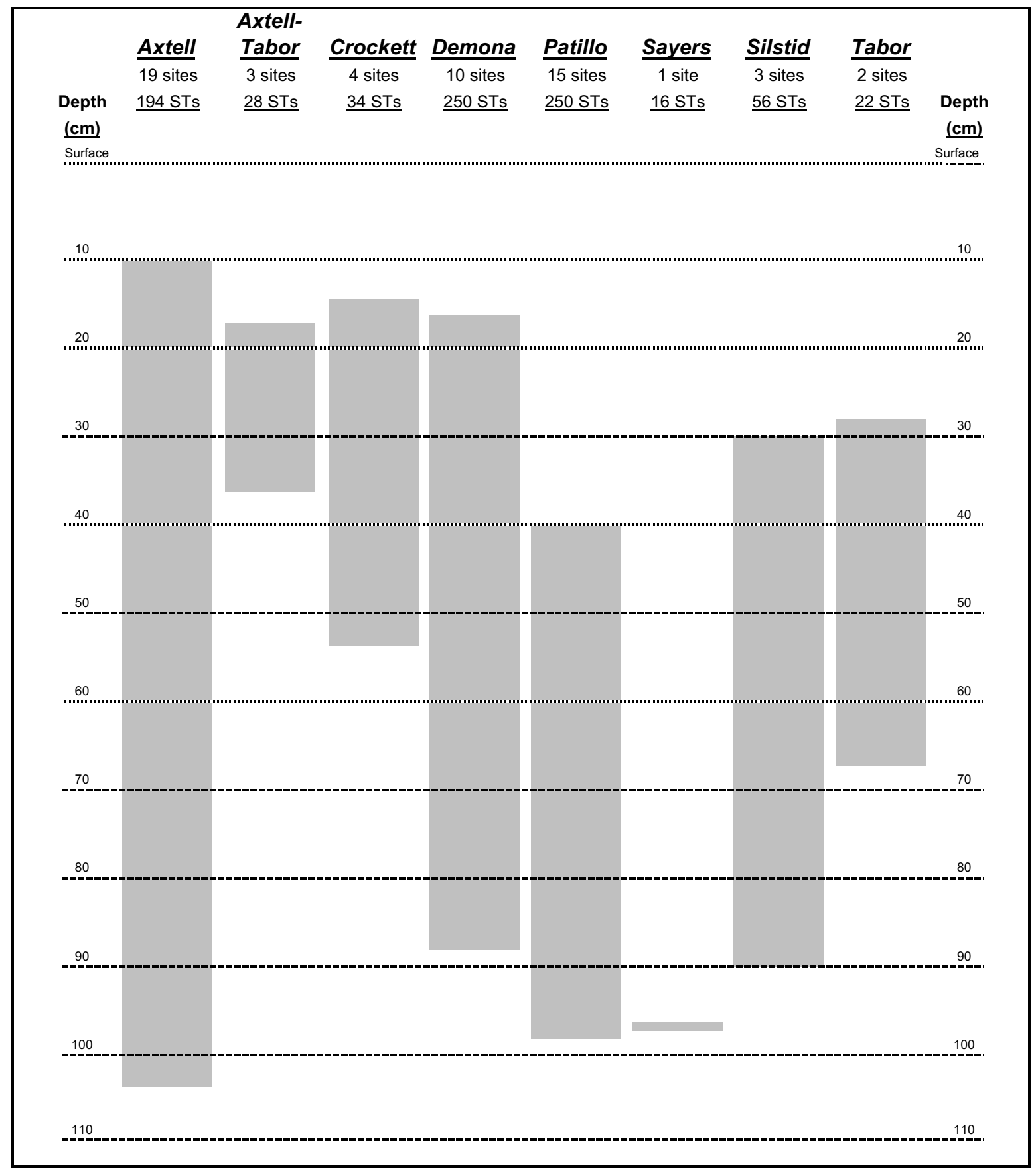

Figure 5-2. Range of mean shovel test depths within soil types for the 39 sites shovel tested in 2001, and the 18 sites shovel tested during this project.

nation of Figure 5-2 reveals that we found a very broad range in depths in Axtell, Demona, Patillo, and Silstid soils. In comparison, the ranges of mean depths in Axtell-Tabor, Crockett, and Tabor soils were relatively narrow. Only one site tested was in Sayers.
In sum, by conducting an additional 306 shovel tests on 18 additional sites at Camp Swift, the results vary only slightly from our 2001 project; there appears to be no discrete range of patterned depths in any particular soil, and thus consistent 


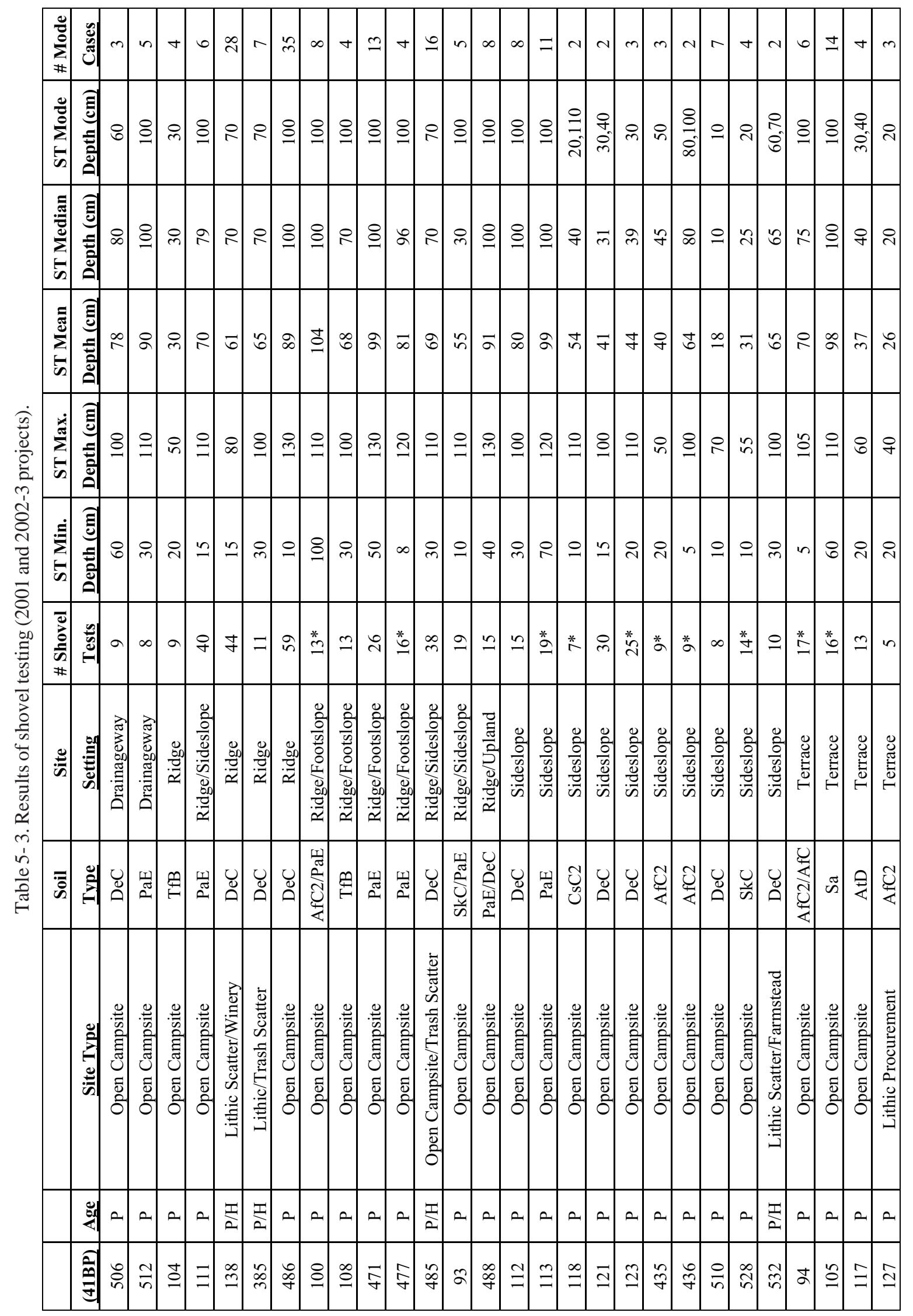




$$
\begin{aligned}
& \text { o m } m \text { m }
\end{aligned}
$$

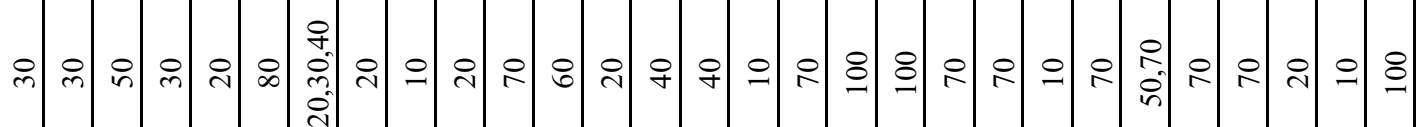$$
\text { m }
$$

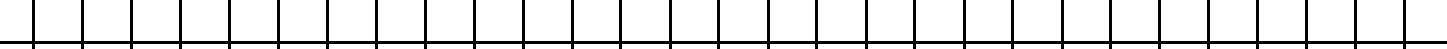

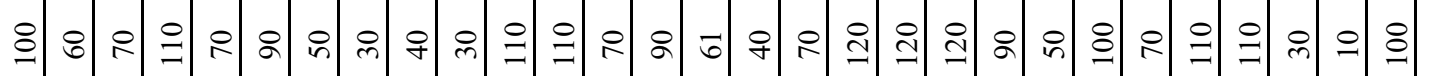

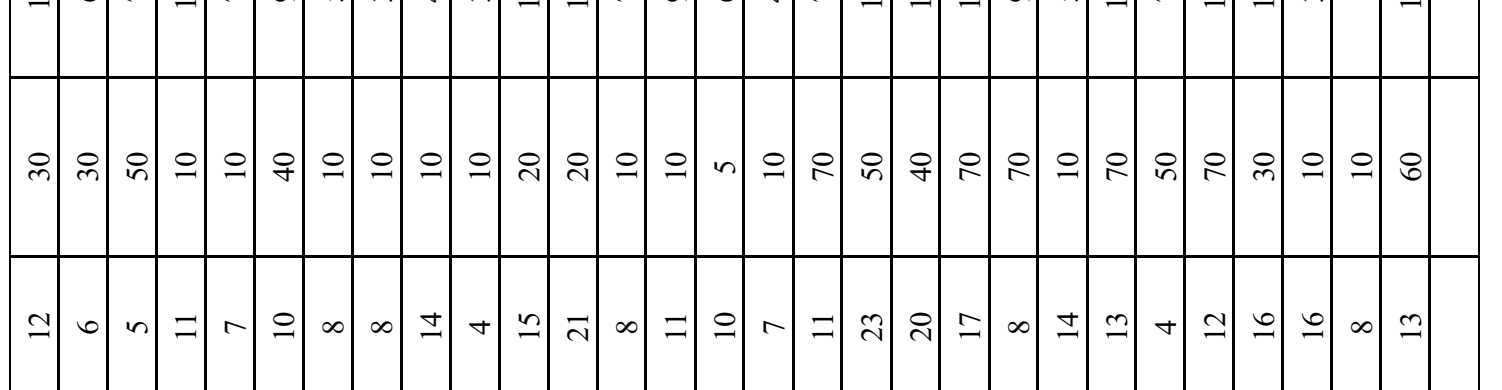

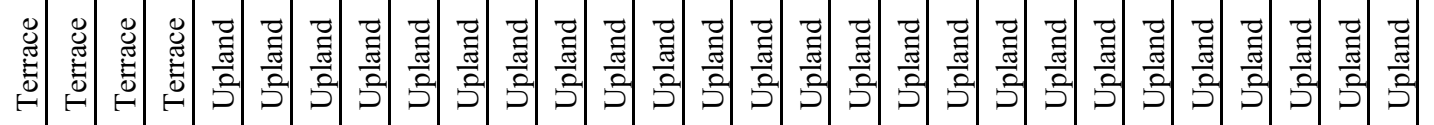

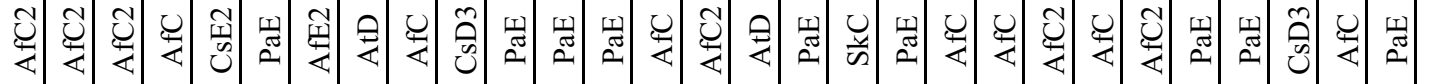

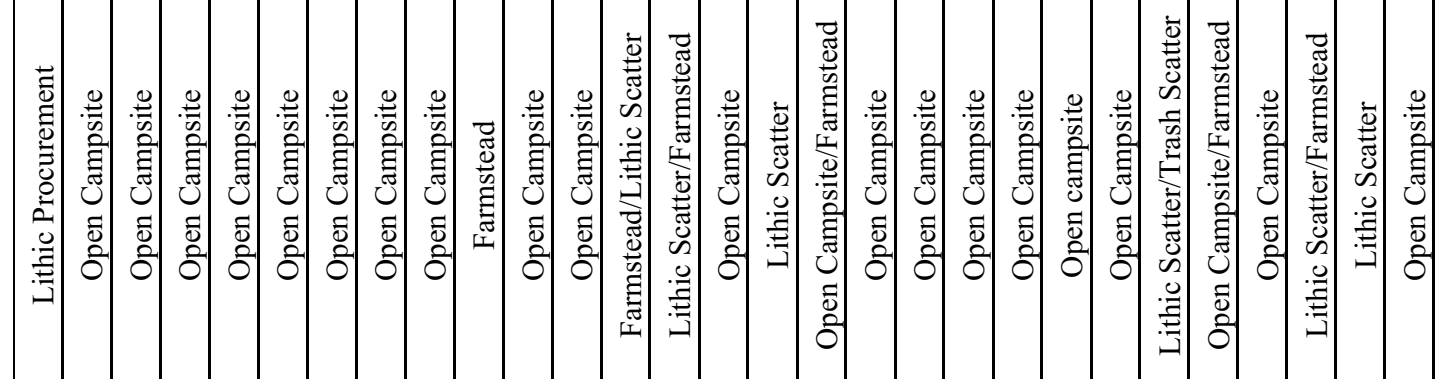

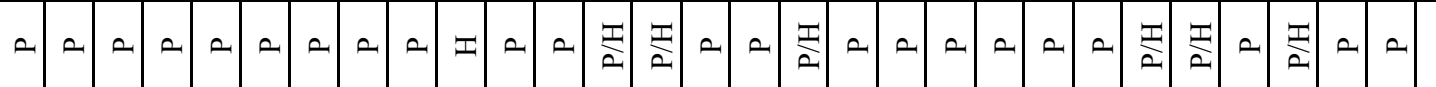

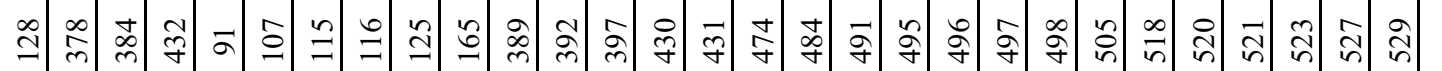


with any particular setting (see Nickels et al. 2003:140 for comparison). However, to further evaluate this observation, we compared mean shovel depths with settings, regardless of soil type. The minimum, maximum, and mean depths of shovel tests are shown in Figure 5-3, and the range of mean depths are further illustrated in Figure 5-4.

An examination of Table 5-2, along with Figures 5-3 and 5-4 reveals the following about the total 59 sites shovel tested in 2001 and during this project:

\section{Upland Sites $(n=25)$}

A total of 25 upland sites were shovel tested; 22 in 2001 and three during this project. Mean depths on upland sites broadly range from 10 to $95 \mathrm{~cm}$, minimum depths broadly range from 5 to $70 \mathrm{~cm}$, and maximum depths broadly range from 10 to $120 \mathrm{~cm}$. The only change that occurred by testing an additional three sites during this project was a change in the minimum depth from $10 \mathrm{~cm}$ to $5 \mathrm{~cm}$.

\section{Terrace Sites $(n=8)$}

A total of eight sites were shovel tested; six in 2001 and two during this project. With the additional testing on two more terrace sites, the mean depths now range between 26 and $98 \mathrm{~cm}$. This is a broader range than we found during the 2001 project, where the mean depths formed a more coherent, tighter pattern ranging between only 26 and $58 \mathrm{~cm}$. The minimum depths now range between 5 and $60 \mathrm{~cm}$, compared to between 10 and $50 \mathrm{~cm}$ after the 2001 project. Maximum depths we encountered on terrace sites during the current project are the same as during the 2001 project — between 40 and $110 \mathrm{~cm}$.

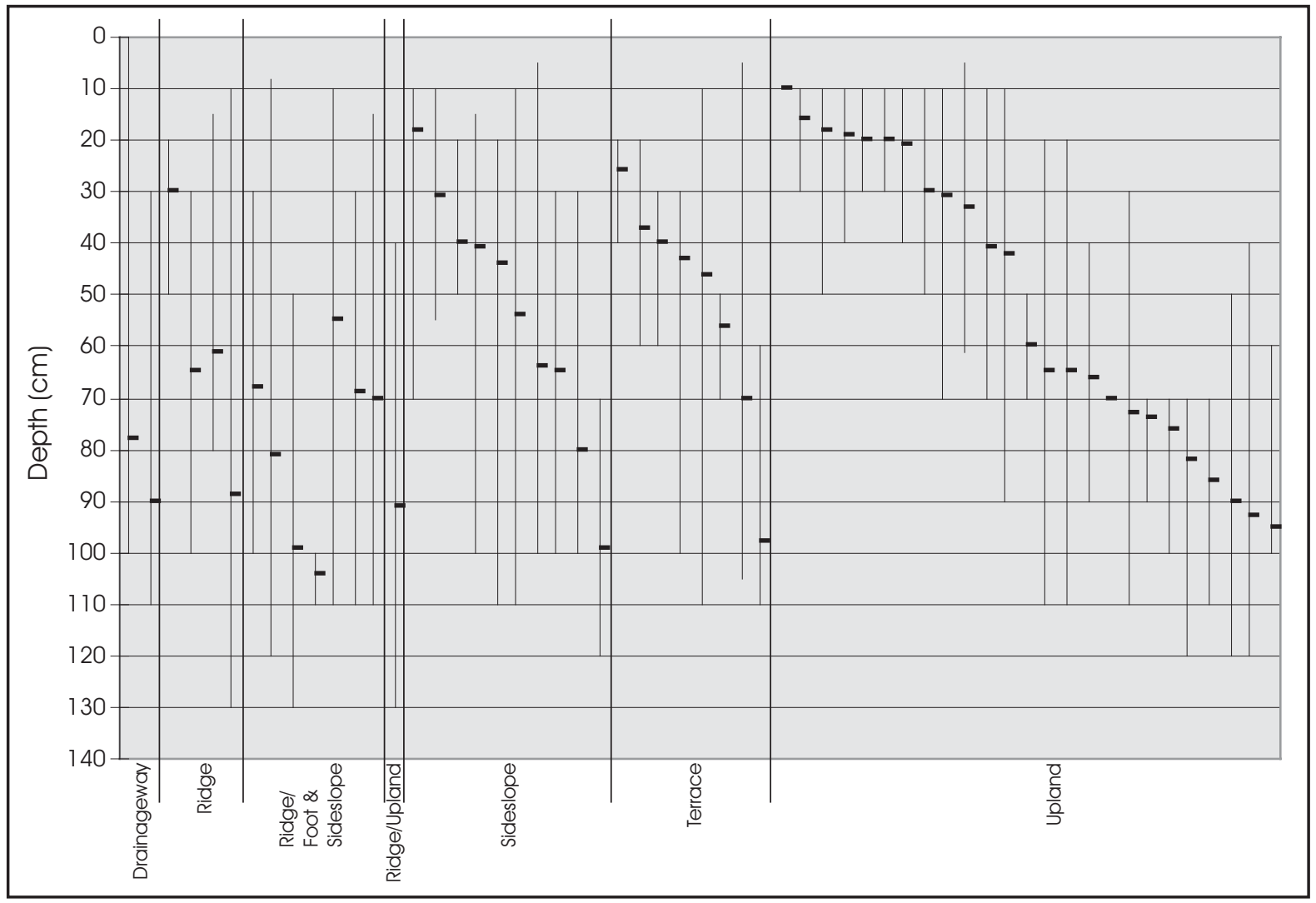

Figure 5-3. Minimum, maximum, and mean depths of shovel tests in varied settings; 39 sites tested in 2001, and 18 during this project. 


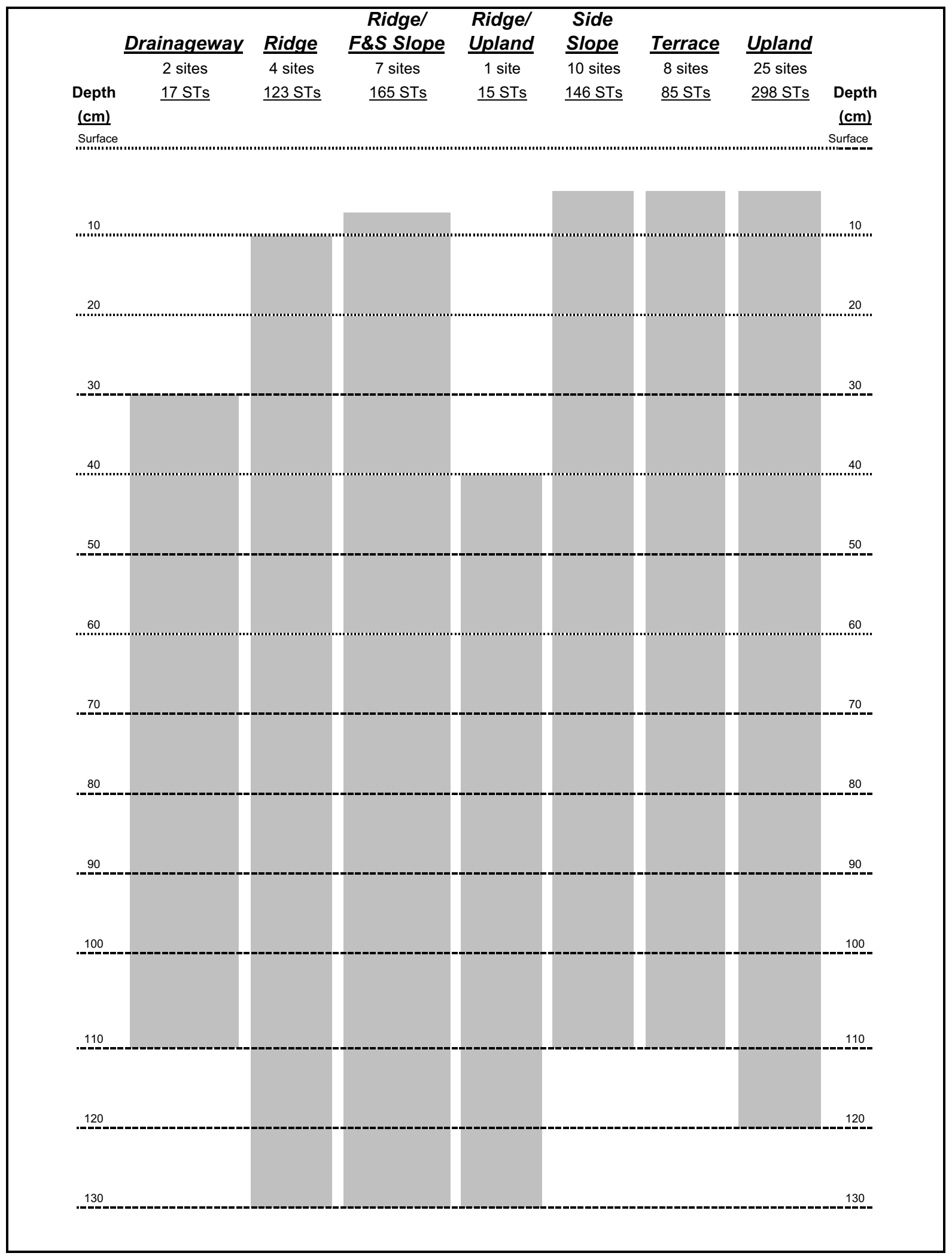

Figure 5-4. Ranges of mean depths of shovel tests within different settings. 
Sideslope Sites $(n=10)$

We shovel tested only three sideslope sites in 2001, but added an additional seven during this project. As we found during the 2001 testing, depths on sideslope sites still range in an incoherent pattern, similar to upland sites. The means range for the ten sites has now increased from 18-80, to 18100. The minimum depths now range between 5 and $70 \mathrm{~cm}$, compared to between 10 and $30 \mathrm{~cm}$ before the current project. Finally, the maximum depths are now between 50 and $110 \mathrm{~cm}$, as compared to 70 and $100 \mathrm{~cm}$ after the 2001 project.

\section{Ridge/Upland Site $(n=1)$}

No additional ridge/upland sites were tested during the current project. Thus there are no changes from the 2001 results. The broad range in depths documented on the single ridge/upland site we tested is again similar to many of the deeper upland sites. Its mean depth is $91 \mathrm{~cm}$, its minimum depth is $40 \mathrm{~cm}$, and its maximum depth is $130 \mathrm{~cm}$.

\section{Ridge/Footslope or Sideslope Sites $(n=6)$}

By testing an additional four sites during the current project, the changes in depths are most obvious when comparing the mean depths. Whereas, after testing only two sites in 2001, their mean depths were a tight 68 and $69 \mathrm{~cm}$, the mean depths of all six sites now range between 55 and $104 \mathrm{~cm}$. The minimum depths now range between 8 and $100 \mathrm{~cm}$, compared to $30 \mathrm{~cm}$ for the two 2001 sites. Interestingly, the maximum depths obtained for both projects are relatively deep; during the 2001 project they were between 100 and $110 \mathrm{~cm}$, and are now between 100 and $130 \mathrm{~cm}$.

\section{Ridge Sites $(n=4)$}

We shovel tested a total of four sites located on ridges; three in 2001 and one during this project. Even though we tested the additional site, the results present no changes in the mean, minimum, or maximum depths on ridge sites. Their mean depths range between 30 and $89 \mathrm{~cm}$, their minimum depths now range between 10 and $30 \mathrm{~cm}$, and their maximum depths between 50 and $130 \mathrm{~cm}$.

\section{Drainageway Sites $(n=2)$}

We did not shovel test any drainageway sites during the current project. The mean depths of the two sites tested in 2001 range between 78 and 90 $\mathrm{cm}$, their minimum depths are 30 and $60 \mathrm{~cm}$, and their maximum depths are 100 and $110 \mathrm{~cm}$. Perhaps not surprisingly, these two exhibit a coherent pattern in depths similar to the two ridge/footslope or sideslope sites we tested, suggesting that in this case terminology for all these settings may be a matter of semantics.

\section{Conclusions}

In general, when comparing the testing results from the 2001 project with the current project, we found few significant differences in the depths of sands and sandy loams on the seven different terrain features at Camp Swift. At the 25 upland sites there is still a very broad range in depths, from 5 to $120 \mathrm{~cm}$. On Terrace sites we now have a broader range of soils depths, from 5 to $110 \mathrm{~cm}$. Sideslopes have soils ranging in depths from 5 to $110 \mathrm{~cm}$. Soils ranged in depths from 40 to $130 \mathrm{~cm}$ on the single ridge/upland site we tested. On ridge footslope or sideslope sites, the soils ranged in depths from 8 to $130 \mathrm{~cm}$. Ridge sites contained soils ranging in depths from 10 to 130 $\mathrm{cm}$, and drainageway soils ranged in depths from 30 to $110 \mathrm{~cm}$.

\section{Depths of Cultural Materials}

We looked at the vertical distribution of chipped stone for the 35 prehistoric components that yielded cultural material during this project and the 2001 project. The recovery data is shown in Table 5-4, and is illustrated in Figures 5-5a through $\mathrm{f}$. 
The reader is reminded that generally, shovel tests did not exceed $100 \mathrm{~cm}$ and therefore the data from $100-130 \mathrm{~cm}$ is heavily skewed; we only dug below $100 \mathrm{~cm}$ when cultural material was present. This is most obvious in Figure 5-5b; one flake was recovered in each of the two levels between 110 and $130 \mathrm{~cm}$, skewing the "\# of pieces recovered" to 1 per level. However, in the upper levels interesting patterns have emerged by combining the 2001 shovel test results (Nickels et al. 2003) with those from this project.

For this analysis we used data only from sites that had positive shovel tests. No additional ridge/ upland sites were tested under the current project, but an examination of Figures 5-5a through $\mathrm{f}$ reveals that the highest density of chipped stone still occurs in ridge/upland settings, while the least density now occurs on pure ridge sites (versus terrace and sideslope settings following the 2001 investigations).

No new ridge/upland sites were tested in 2003, so there is no change; Figure $5-5 \mathrm{~b}$ shows an increase in chipped stone density occurring between 50-60 cm, 80-90 cm, and 100-110. We caveat the explanation of this pattern by again pointing out the small numbers (Table 5-4), and suggest that additional testing of ridge/upland sites is needed before a valid assessment can be made.

As a result of combining the results of both projects, we found no significant changes in the vertical distribution of chipped stone in upland sites (Figure 5-5a), and an increasing density pattern still occurs between 30-50 cm. On Ridge sites, we now see a less pronounced peak in density between 10 $20 \mathrm{~cm}$, but the increase between $30-50 \mathrm{~cm}$ is now more pronounced (Figure 5-5c).

One of the more significant changes in patterns was realized when graphing the shovel test data from ridge/foot \& sideslope sites. After reviewing the data from our 2001 project, we saw a very pronounced increase in chipped stone density between 40-90 cm (see Nickels et al. 2003:144). However, after combining the results from both projects, we now see a rather homogeneous vertical pattern (Figure 5-5d).

Too little data was obtained in 2001 on sideslope and terrace sites to make any valid observations. However, an examination of Figure 5-5e reveals a rather consistent pattern in chipped stone density between 40-70 cm, followed by an increasing trend between 70-110 cm on sideslope sites. Figure 5-5f shows a pronounced increase in densities between $20-60 \mathrm{~cm}$, followed by a less pronounced peak in density between $70-80 \mathrm{~cm}$.

Finally, we observed general trends in increasing flake densities occurring between $30-60 \mathrm{~cm}$, and possibly in lower levels. To further investigate these general observations, we combined all pieces of chipped stone $(n=687)$ regardless of site setting. The results shown in Figure 5-6 represent a macroscale vertical distribution of chipped stone from 35 sites that are spread across all terrain settings and soil types at Camp Swift (Note that densities are multiplied by 100). Interestingly, the results indicate a clear, increasing trend in densities from 20 to 60 $\mathrm{cm}$, followed by a general increase from 70 to 90 $\mathrm{cm}$. Although there may be a third trend developing below $100 \mathrm{~cm}$, we do not have sufficient data to speculate further.

We were aware that by looking solely at chipped stone distribution, an argument could be made that the peaks in chipped stone densities occur because the pieces have moved downward through the sandy soils, and have settled on the underlying clay surfaces. If this was the case, then we would expect to see congruent trends in chipped stone density and clay depths. Therefore, for those 


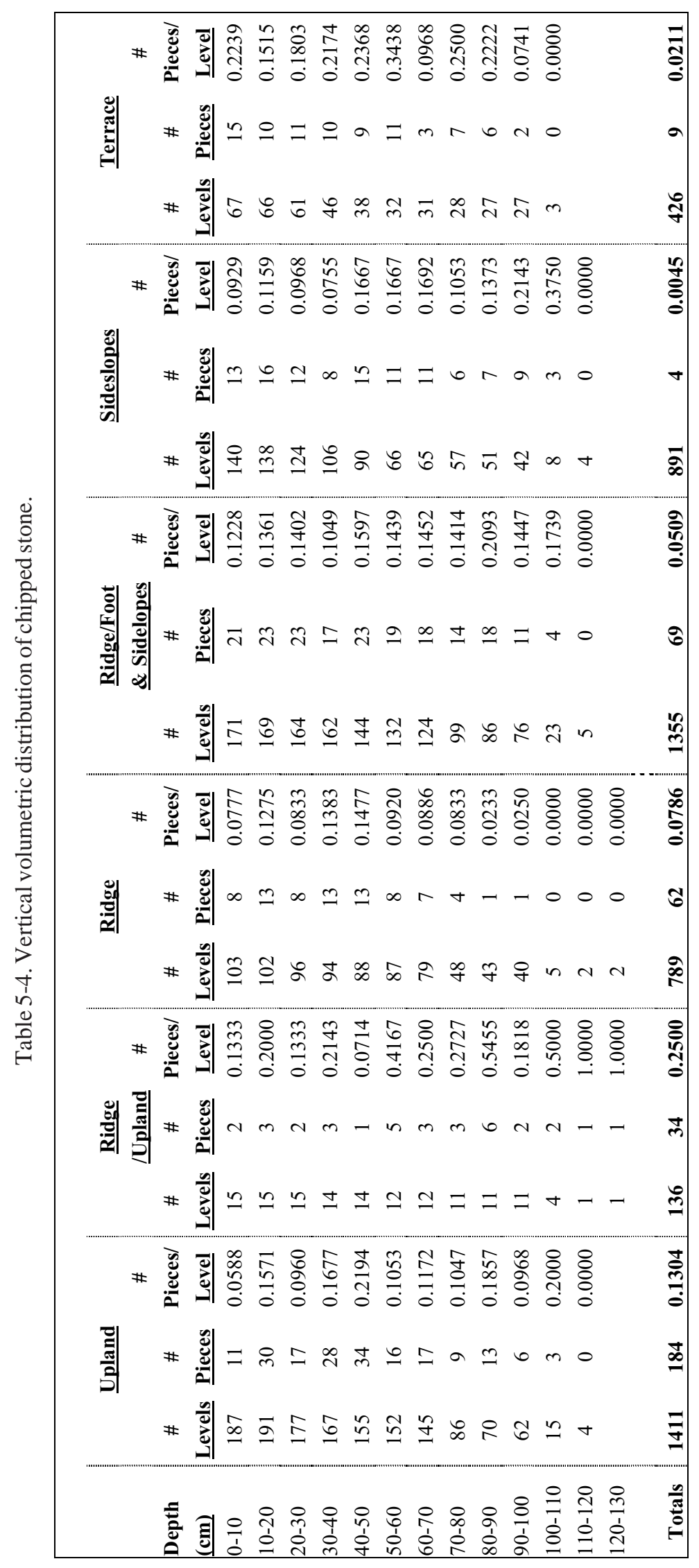




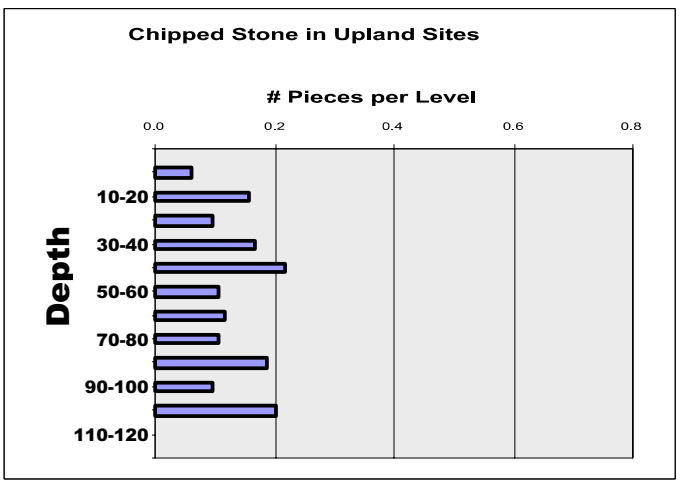

a.

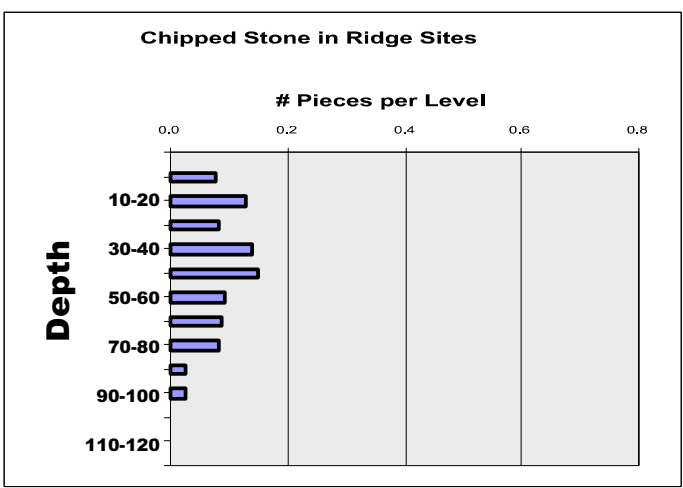

c.

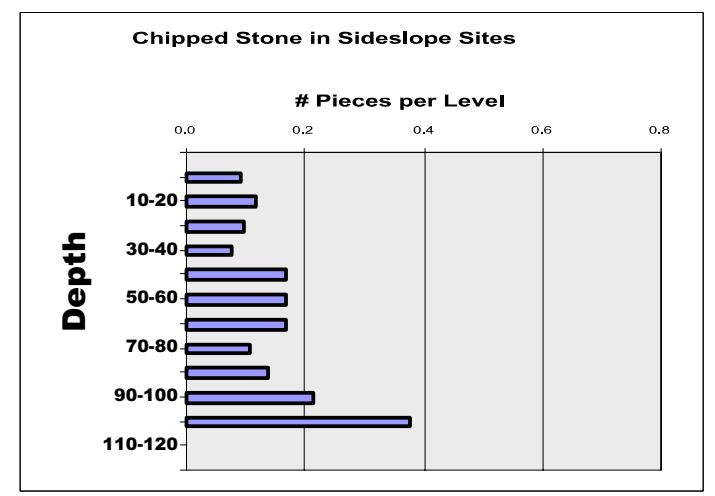

e.

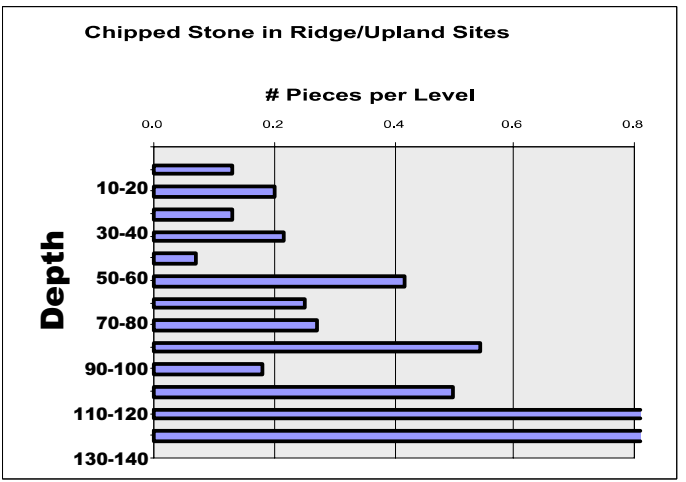

b.

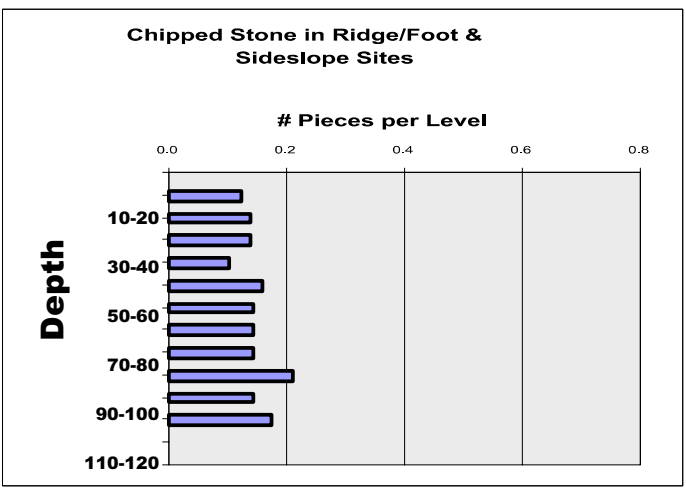

d.

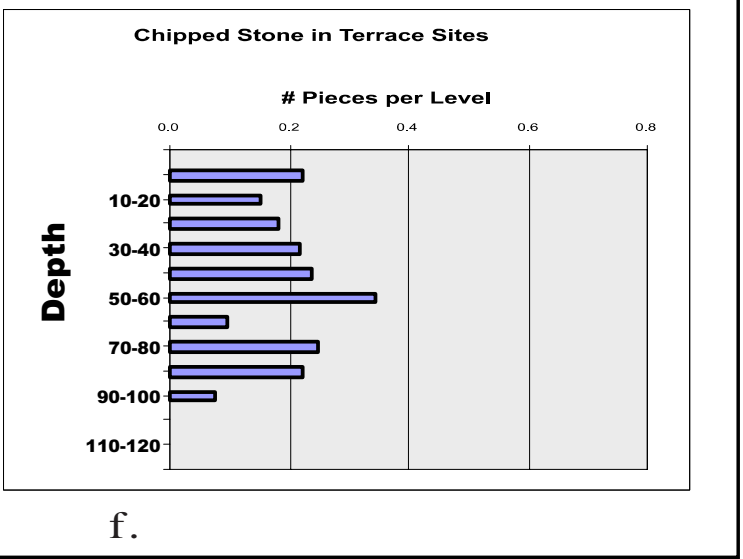

Figures 5-5a through $\mathrm{f}$. Volumetric distribution of chipped stone by setting.

35 sites where we recovered chipped stone, we looked at the depths of all shovel tests that encountered clay. Figure 5-6 illustrates the results of our analysis on clay depths. For example, we hit clay between $0-10 \mathrm{~cm} 20$ times.
Notably, although the trends in chipped stone densities and clay depths are not necessarily congruent, the trends are such that the above argument cannot be ruled out. Further investigations beyond the scope of this shovel testing project is needed so that this issue can be addressed more fully. 


\section{Site Integrity: Vertical Distribution of Cultural Remains}

\section{GeneralDiscussion}

A more detailed discussion of this issue was presented following our 2001 testing project at Camp Swift (Nickels et al. 2003:145-147), and thus will merely be highlighted here. When addressing the issues of site integrity of cultural material within the sandy mantle, one of the methods to evaluate vertical movement is to examine patterns which may be attributed to size sorting, or the upward and burrowing. Human post-depositional influences on artifacts may include trampling, tool reuse, the digging of postholes, storage pits, baking pits, or burial graves, and the borrowing of sediments for sealing cooking ovens or ceramic manufacture.

Yellen (1977:103), Gifford and Behrensmeyer (1977), and Stockton (1973) argue that trampling will cause the smaller artifacts to move downward, while generally leaving the larger artifacts on or very near their original surface. Periodic wetting and drying causing vertical cracking of soils due to percolating rainwater, and an oscillating watertable will also cause artifacts to move downward (Cahen and Moeyersons 1977).

Soil types and textures certainly are a variable in the extent that vertical movement of artifacts can occur, and Stockton $(1973,1977)$ argues that the phenomena can occur in all types of deposits, whether mostly sand, or a mixture of sand, silt, and clay. Gifford-Gonzalez and others (1985:808) have demonstrated in experimental studies that 94 percent of artifacts recovered in loamy soils were vertically within $1 \mathrm{~cm}$ of their original placement after trampling, and the looser downward movement of artifacts caused by postdepositional processes. A few of these processes include frost heave, dry soil creep, solifluction (saturated soil creep), and subsidence (sinking) in cave deposits. Although in some cases these processes are easily identifiable in the field, in many other cases they are not. Another post-depositional disturbance often overlooked is biogenic perturbation, e.g., termites, earthworms, and other animal matrix caused by trampling "caught and held smallto medium-sized flakes." Conversely, in sandy soils the majority of artifacts easily worked their way downward, at least until they encountered a moist layer of sand.

Gifford-Gonzalez and others (1985) concluded from their experiments and those of Villa and Courtin (1983) that length, weight and volume are 
interrelated variables that affect the downward displacement of flakes caused by trampling, and thus statistically can be used interchangeably to evaluate their stratigraphic integrity. For purposes of this study we have combined both approaches; in 2001, we used mean flake length of unbroken flakes (see Nickels et al. 2003:147-148), and for this project we used mean flake weight for both broken and unbroken flakes.

\section{CampSwift}

The sediment and clay soils depositional context in the floodplains of Big Sandy and McLaughlin Creeks is such that vertical movement of artifacts through layered sediment and soil packages due to size sorting should not be as problematic as it is in the sandy soils overlying the valley walls and uplands (e.g., Stevenson 1991; Vierra 1998). However, in either setting or soil structure, comparing the mean flake length of complete flakes, and the mean weight of incomplete flakes with the soil zones and horizons identified in the geomorphological study to evaluate the stratigraphic differences in size sorting is a viable means to evaluate site integrity.

As discussed previously, in addition to bioturbation caused by animals and plants, various natural processes such as creeping, heaving, and cracking cause buried artifacts to move vertically within different soil types. More specifically, we attempted to demonstrate the potential vertical integrity of artifacts within the sand and sandy loam soils that are predominant on Camp Swift.

A total of 203 flakes from 35 prehistoric components shovel tested in 2001 and 2003 were measured to the nearest minimum centimeter (108 measured in 2001, 95 in 2003). Soils on all sites were either sand or some combination of sand and loam. Because of the small sample size per site, all flakes were lumped into a single sample, regardless of physiographic settings. Table 5-5 presents the mean data, and Figure 5-7 illustrates the vertical distribution of mean flake length for all 35 sites, with chipped stone densities and clay depths included.

We admitted in the previous section in conjunction with Figure 5-6, that the trends in chipped stone densities and clay depths are not necessarily congruent, but are such that conceivably, the increase in chipped stone densities could be influenced by varying levels of hard clay surfaces. However, an examination of Figure 5-7 illustrates how closely the vertical trend in sizes of unbroken flakes follows the vertical trend in number of pieces of chipped stone. The slight, but general increases in flake size between 30-60 cm, and again from between 70-90 $\mathrm{cm}$ mirror the increases in chipped stone densities.

There are two interpretations that can be made from this limited data: (1) increases in flake size are

Table 5-5. Minimum mean lengths of complete flakes recovered from shovel tests during the 2001 and 2003 Camp Swift projects.

\begin{tabular}{|c|c|c|c|r|c|c|c|c|}
\hline $\begin{array}{c}\text { Depth } \\
(\mathbf{c m})\end{array}$ & $\begin{array}{c}\# \\
\text { Flakes }\end{array}$ & $\begin{array}{c}\text { Mean } \\
\text { Length (cm) }\end{array}$ & $\begin{array}{c}\text { Depth } \\
\text { (cm) }\end{array}$ & $\begin{array}{c}\# \\
\text { Flakes }\end{array}$ & $\begin{array}{c}\text { Mean } \\
\text { Length (cm) }\end{array}$ & $\begin{array}{c}\text { Depth } \\
\text { (cm) }\end{array}$ & $\begin{array}{c}\# \\
\text { Flakes }\end{array}$ & $\begin{array}{c}\text { Mean } \\
\text { Length (cm) }\end{array}$ \\
\hline $0-10$ & 23 & 1.30 & $50-60$ & 18 & 1.61 & $100-110$ & 3 & 1.50 \\
\hline $10-20$ & 32 & 1.03 & $60-70$ & 23 & 1.09 & $110-120$ & 1 & 1.00 \\
\hline $20-30$ & 21 & 1.17 & $70-80$ & 15 & 1.20 & & & \\
\hline $30-40$ & 19 & 1.29 & $80-90$ & 16 & 1.49 & & & \\
\hline $40-50$ & 25 & 1.26 & $90-100$ & 8 & 1.31 & & & \\
\hline
\end{tabular}


simply a result of increased reduction activities, or (2) increases in flake size data, as with flake densities, are a result of larger flakes moving downward and resting on the underlying Bt Horizon. We reiterate here that further investigations beyond the scope of this shovel testing project is needed so that this issue can be addressed more fully.

\section{Prehistoric Site Significance Relative to Soil Types}

Following our shovel testing of 38 prehistoric sites at Camp Swift in 2001 (see Nickels et al. 2003), we attempted to create a predictive model for site significance based upon soil types. We based our predictions upon our results of shovel testing those 38 sites, the results of previous investigations on other Camp Swift sites (Mauldin 2001) - for a total of 81, and the soil types on which all sites were situated.
Our Graphic Information Systems (GIS)-based model allowed for predicting the significance of the 18 prehistoric component sites evaluated during this project. Detailed plotting of the 81 previously evaluated sites over a soils map of Camp Swift allowed us to calculate the percentages of significant sites (based upon previous testing) by soil types. Table 5-6 shows the results.

Based on the soils types on sites to be evaluated during this project, we calculated the likelihood of these sites being potentially significant. Table 5-7 summarizes our expectations, versus our assessment after shovel testing.

In summary, it is very apparent that either (1) our model using soil types as a basis for predicting site significance does not work, or (2) our shovel testing effort was insufficient to accurately evaluate the potential of each site. In either case, further excavations of the ten sites now determined as potentially significant after shovel testing are needed in order to fully evaluate the model.

\section{Summary and Conclusion}

In this chapter we attempted to address issues involving the potential for buried sites in the sandy mantle, site integrity relative to terrain features and soils, and the significance evaluations placed upon sites, relative to the types of soils within which they are found.

First, we examined the vertical densities of chipped stone found on sites within various terrain types. The highest density of 
Table 5-6. Significance of 81 previously investigated prehistoric sites: significance relative to soil types on Camp Swift.

\begin{tabular}{|l|c|c|c|}
\hline Soils & $\begin{array}{c}\text { \# Potentially } \\
\text { Significant }\end{array}$ & \# Insignificant & $\begin{array}{c}\% \\
\text { Significant }\end{array}$ \\
\hline Axtell fine sandy loam (AfC, AfC2) & 3 & 11 & $21.4 \%$ \\
\hline Axtell-Tabor complex (AtD) & 1 & 2 & $33.3 \%$ \\
\hline Crockett soils (sandy loam) (CsD3, CsE2) & 0 & 4 & $0.00 \%$ \\
\hline Demona loamy fine sand (DeC) & 3 & 10 & $23.1 \%$ \\
\hline Jedd stony soils (JeF) & 0 & 1 & $0.0 \%$ \\
\hline Patilo complex (sandy) PaE & 11 & 12 & $47.8 \%$ \\
\hline Sayers fine sandy loam (Sa) & 0 & 7 & $0.0 \%$ \\
\hline Silstid loamy fine sand (Skc) & 0 & 5 & $0.0 \%$ \\
\hline Tabor series fine sandy loam (TfB) & 1 & 3 & $25.0 \%$ \\
\hline Uhland soils, frequently flooded (loamy) (Uh) & 0 & 5 & $0.0 \%$ \\
\hline
\end{tabular}

Table 5-7. Our expectations based on our predictive model, and later determinations of significance based on shovel testing.

\begin{tabular}{|c|c|c|c|}
\hline Soils & Sites to be evaluated & $\begin{array}{c}\text { Predicted \# } \\
\text { likely to be } \\
\text { significant }\end{array}$ & $\begin{array}{c}\text { Site(s) now determined as } \\
\text { potentially significant after } \\
\text { shovel testing }\end{array}$ \\
\hline $\begin{array}{c}\mathrm{AfC}, \\
\mathrm{AfC} 2\end{array}$ & $41 \mathrm{BP} 430,41 \mathrm{BP} 435,41 \mathrm{BP} 436$ & 1 & None \\
\hline $\mathrm{CsC} 2$ & $41 \mathrm{BP} 113$ & 0 & $41 \mathrm{BP} 113$ \\
\hline $\mathrm{DeC}$ & $41 \mathrm{BP} 111,41 \mathrm{BP} 118,41 \mathrm{BP} 121$, & 1 & $41 \mathrm{BP} 111,41 \mathrm{BP} 118,41 \mathrm{BP} 121$ \\
\hline $\mathrm{PaE}$ & $41 \mathrm{BP} 123$ & & $41 \mathrm{BP} 471,41 \mathrm{BP} 477,41 \mathrm{BP} 491$ \\
\hline $\mathrm{Sa}$ & $41 \mathrm{BP} 105$ & 0 & $41 \mathrm{BP} 105$ \\
\hline $\mathrm{TfB}$ & $41 \mathrm{BP} 431$ & 0 & None \\
\hline $\mathrm{Uh}$ & $41 \mathrm{BP} 94,41 \mathrm{BP} 100 \quad$ Totals & $\mathbf{4}$ & $41 \mathrm{BP} 94,41 \mathrm{BP} 100$ \\
\hline & & & $\mathbf{1 0}$ \\
\hline
\end{tabular}

chipped stone still occurs in ridge/upland settings, while the least density now occurs on pure ridge sites (versus terrace and sideslope settings following the 2001 investigations).

Although the numbers of chipped stone are few and additional testing of ridge/upland sites is needed before a valid assessment can be made, there is an increase in chipped stone density occurring between $50-60 \mathrm{~cm}, 80-90 \mathrm{~cm}$, and 100-110.

As a result of combining the results of both projects, we found no significant changes in the vertical distribution of chipped stone in upland sites, and an increasing density pattern still occurs between 30-50 cm. On Ridge sites, we now see a less pronounced peak in density between $10-20 \mathrm{~cm}$, but the increase between $30-50 \mathrm{~cm}$ is now more pronounced.

After combining the results from both our 2001 project and this project, we now see a rather homogeneous vertical pattern in buried chipped stone densities on ridge/foot \& sideslope sites.

On sideslope sites we see a rather consistent pattern in chipped stone density between 40-70 $\mathrm{cm}$, followed by an increasing trend between 70 
$110 \mathrm{~cm}$. On terrace sites we see a pronounced increase in densities between 20-60 cm, followed by a less pronounced peak in density between 70 $80 \mathrm{~cm}$.

Next, we attempted to address the argument that artifacts move downward easily through sandy soils, but then become stratified on the underlying Bt horizon. Normally, we would interpret peaks in artifact densities as correlates to increased occupation levels, and corroborated by other lines of evidence such as archaeomagnetic, soil susceptibility, and $\mathrm{pH}$ analysis. During this shovel testing project, we did not collect any potentially corroborating special samples, so instead we compared the trends in chipped stone densities by excavated level, with the depths of clay encountered on 35 sites tested during this project and a 2001 project (Nickels et al. 2003). Although the trends are not congruent, we cannot rule out the possibility that artifacts may be moving downward to the underlying hard clay strata. Further investigations beyond the scope of this shovel testing project are needed so that this issue can be addressed more fully.

Following our 2001 project at Camp Swift, we attempted to develop a predictive model of site significance using soil types (and by association, landforms) as a basis for predicting the significance of the 18 prehistoric components tested during this project. In summary, it is very apparent that either (1) our model using soil types as a basis for predicting site significance does not work, or (2) our shovel testing effort was insufficient to accurately evaluate the potential of each site. In either case, further excavations of the ten sites now determined as potentially significant after shovel testing are needed in order to fully evaluate the model.

In conclusion, our assessments regarding site significance relative to terrain feature and/or soil types have changed little from those presented following our 2001 shovel testing project at Camp Swift (Nickels et al. 2003). That is, we conclude that the physiographic setting cannot be viewed as an overriding consideration when evaluating site depth, intensity of use, and integrity. Instead, sites must be tested and evaluated on a case-by-case basis regardless of their setting on the Camp Swift landscape.

\section{Section II: Historic Issues}

Department of the Interior Regulations 36 CFR 60 provide for National registration of historic properties that:

A) are associated with events that have made a significant contribution to the broad patterns of our history; or

B) are associated with the lives of persons significant in our past; or

C) embody the distinctive characteristics of a type, period, or method of construction, or that represent the work of a master, or that possess high artistic values, or that represent a significant and distinguishable entity whose components may lack individual distinction; or

D) have yielded, or may yield, information important in prehistory or history.

In addition, the integrity of individual properties should be evaluated in relation to like properties with a similar cultural theme, within the same geographical area, and generally within the same frame. It is within these contexts and criterion which we assessed the integrity of the historic components. During the 1979 investigations of historic properties on 4,000 acres at Camp Swift, Martha Doty Freeman (Skelton and Freeman 1979) identified 43 historic sites, and from various sources 
determined there were likely several more not found during the survey. Although not specifically addressed as criterion for eligibility, Freeman discusses thematic issues such as early frontier settlement, pre-Civil War and post-Civil War plantation/ farming activities, unique group settlement patterns tethered by family relations, and industrial development. In addition to Criterion $\mathrm{A}$ through $\mathrm{D}$, it is within this framework that we intended to further evaluate each site. 



\section{Chapter 6}

\section{Summary ANd Recommendations}

\section{David L. Nickels}

\section{Project Summary}

The Texas Army National Guard continues to use Camp Swift for military training, and as required by law, an environmental assessment of the areas to be impacted was conducted. A total of 18 previously discovered prehistoric archaeological sites were revisited, shovel tested, and otherwise documented by archaeologists from the Center for Archaeological Studies - Southwest Texas State University. In addition, two previously discovered historic sites were further mapped and inventoried. This project was undertaken to meet the requirements of Sections 106 and 110 of the National Historic Preservation Act (NHPA). Under these Sections, the protection of cultural resources is related to their eligibility for inclusion in the National Register of Historic Places (NRHP), which is in turn dependent on their significance as defined in 36 CFR Part 60.

\section{Project Results}

Of the 20 documented sites, 15 have prehistoric components only, 3 have both prehistoric and historic components, and 2 sites have only a historic component. CAS personnel conducted a limited surface collection of unique items, and collected all subsurface artifacts recovered from a total of 311 shovel tests on 18 sites.

\section{Management Considerations - Prehistoric Components}

The purpose of this testing project was to provide the Texas Army National Guard with recommendations as to the eligibility of the sites for nomination to the National Register of Historic Places (NRHP). In the case of prehistoric sites, significance is normally based on Criterion $\mathrm{D}$ of the National Historic Preservation Act (NHPA) as defined by the National Park Service in 36 CFR 60. The significance of a site under Criterion D, and therefore its eligibility for listing on the NHRP, is based on its having yielded information important in history or prehistory, oron its having the potential to yield such information in the future. The question of what information is important, a point not addressed in the NRHP, is a function of research questions or developed historic contexts.

Our assessment of research potential is primarily based on the physical integrity of sites, the archaeological evidence present at a specific site, and the potential for significant research issues to be addressed by an investigation of the site. If deposits are significantly mixed, the potential of the assemblage to address the historic context issues discussed in Chapter 6 is significantly impeded. Although we agree that the research potential of a site is viewed as a continuum; different levels of 
integrity are relevant for addressing different research issues. Nevertheless, sites with high physical integrity are more likely to yield data sets that are potentially capable of addressing a wider variety of research issues. The surface assemblages set on eroded sediments are deflated, and generally represent palimpsests in secondary contexts. As such their research potential is considered minimal. However, in many cases, it appears there may be intact deposits below the surface, Therefore, we rely primarily on the results obtained from shovel testing to assess the physical integrity, and research potential of each site. Additionally, the significance of each site was judged based upon its ability to address historic context issues outlined in Chapter 6. Sites were judged based on the following criteria:

High potential: High integrity sites. Sites upon which shovel test results have indicated a pattern of stratified deposits, have potentially buried, intact deposits and/or datable features, and otherwise have the potential to address the research issues discussed in Chapter 5.

Moderate potential: Potentially high integrity sites. Sites upon which shovel testing results have not clearly demonstrated high integrity, but with further testing could yield buried, intact deposits and/or datable features, and otherwise have the potential to address the research issues discussed in Chapter 5.

Minimal potential: Little or no integrity sites. Sites upon which shovel testing results have produced no evidence of intact deposits, and/or have otherwise been disturbed so that there is little or no potential for providing credible information.

As the current project involved only limited shovel testing, recommendations required to made by CAS according to the survey contract were as follows: 1) Eligible for the National Register of Historic Places, 2) Not eligible for the National Register of Historic Places, or 3) Requires further investigation beyond the scope of the inventory survey.

\section{Prehistoric Site Recommendations}

On 11 sites we recommend further investigation. The work plan for those sites should be structured to accommodate levels of effort which will provide sufficient information to determine whether or not sites are intact, and if sites appear to be intact, additional work should be sufficient to formulate and complete a data recovery plan to determine NRHP eligibility. Table 6-1 lists the eleven Category 6 sites that need additional excavation units and/or backhoe trenching to determine their integrity. Buried hearth features were located at three sites during the shovel testing (41BP94, 41BP100, 41BP477). In those cases, we recommend 1x1-m excavation units be used to further investigate those features. Otherwise, we recommend backhoe trenches be used as a primary investigation method, followed by hand excavation of units in locations of features identified during trenching operations. Specifically, backhoe trenching should be conducted to better assess the nature of the sites. Backhoe trench locations should be selected so as to sample areas likely to contain intact features as indicated by the artifact density maps. If warranted, 1x1-m excavation units should be excavated to obtain enough information to develop a data recovery plan.

Although the exact number of trenches dug on any given site should be determined by the project archaeologist in the field, based on shovel testing we are able to provide an estimate of the appropriate number to be placed at each site (see Table 6$1)$. Enough trenches should be dug to verify that 
either there are no intact deposits on the site that warrant test excavations, or that there appear to be intact deposits that warrant controlled excavation. In the latter case, enough information should be collected to allow the formulation of a data recovery plan which may include additional trenches and controlled excavations.

Excavation units should be dug after backhoe trenches have been completed. These controlled excavations should be directed toward investigation of cultural features or artifact concentrations. In the event that a cultural feature is clearly observed in a backhoe trench, the project archaeologist should open up a hand-excavated unit to investigate the feature.

NRHP eligibility is contingent upon the ability of a site to yield whole, significant, and credible information from high integrity contexts. In that regard, critical review should be made of the contextual presence or absence of well-preserved remains such as faunal, botanical, and charcoal, the presence or absence of datable material, the pres- scribe and illustrate the profiles of each backhoe trench. When appropriate, soil particle size analysis, radicarbon assays, magnetic susceptibility, and $\mathrm{pH}$ analysis should be conducted. These data could be used to support conclusions regarding the potential of any given location to yield intact archaeological materials.

\section{Minimum Integrity Site Components}

There are 7 prehistoric sites and/or distinct prehistoric component areas of sites we assess as having little or no integrity, likewise having minimal research potential, and thus recommended as not eligible for the National Register of Historic Places. They are shown in Table 6-1.

\section{Moderate Integrity Site Components}

There are 2 prehistoric site components we assess as demonstrating moderate integrity, and potentially capable of having high research potential; thus we believe further investigation beyond the scope of this inventory survey are required before recommendations can be made regarding their eligibility for nomination to the National Reg-

Table 6-1. Prehistoric component sites assessed as having little or no integrity, or research potential; not eligible for the National Register of Historic Places.

\begin{tabular}{|l|l|l|l|l|l|l|}
\hline Site & Site & Site & Site & Site & Site & Site \\
\hline $41 \mathrm{BP} 93$ & $41 \mathrm{BP} 123$ & $41 \mathrm{BP} 138$ & $41 \mathrm{BP} 430$ & $41 \mathrm{BP} 431$ & $41 \mathrm{BP} 435$ & $41 \mathrm{BP} 436$ \\
\hline
\end{tabular}

ence or absence of diagnostics, the presence or absence of intact features, the association of other cultural debris, and the overall geoarchaeological assessment of the site. Although all of these attributes are uncommon in sandy mantle sites, a combination of at least some of these attributes is critical in positive site evaluation.

Ageomorphologist/gearchaeologist should de- ister of Historic Places. The minimum work required to further assess each site's potential is presented in Table 6-2. Possible additional hand excavated units may be required if potentially intact features are encountered.

\section{High Integrity Site Components}

There are 9 prehistoric site components and/or distinct prehistoric component areas of sites we 
Table 6-2. Prehistoric site components assessed as having moderate integrity, with the capability of demonstrating high integrity and research potential; further investigations are required.

\begin{tabular}{|l|l||l|l|}
\hline Site & Minimum Work Required & Site & Minimum Work Required \\
\hline $41 \mathrm{BP} 118$ & 2 BHTs & 41BP528 & 3 BHTs \\
\hline
\end{tabular}

assess as demonstrating high integrity, and likewise having high research potential. However, we believe further investigations beyond the scope of this inventory survey are required before recommendations can be made regarding their eligibility for nomination to the National Register of Historic Places. The minimum work required to further assess each site's potential is presented in Table 63. Possible additional hand excavated units may be required if potentially intact features are encountered.
Department of the Interior Regulations 36 CFR 60 provide for National registration of historic properties that:

A) are associated with events that have made a significant contribution to the broad patterns of our history; or

B) are associated with the lives of persons significant in our past; or

C) embody the distinctive characteristics of a type, period, or method of construction, or that represent the work of a master, or that possess high artistic values, or that represent a significant and

Table 6-3. Prehistoric site components assessed as demonstrating high integrity, with potentially high research potential; further investigations are required.

\begin{tabular}{|l|l||l|l|}
\hline Site & $\begin{array}{l}\text { Minimum Work } \\
\text { Required }\end{array}$ & Site & $\begin{array}{l}\text { Minimum Work } \\
\text { Required }\end{array}$ \\
\hline 41BP94 & 5 BHTs; 2 Test Units & 41BP121 & 3 BHTs \\
\hline 41BP100 & 4 BHTs; 1 Test Unit & 41BP471 & 5 BHTs \\
\hline 41BP105 & 4 BHTs & 41BP477 & 4 BHTs; 2 Test Units \\
\hline 41BP111 & 5 BHTs & 3 BHTs \\
\hline 41BP113 & 5 BHTs & & \\
\hline
\end{tabular}

\section{Management Considerations - Historic Components}

A total of five historic components were documented during this project; there occupations ranging from the late 1800 s through the early 1940 s. Three are related to early farming activities in the Camp Swift area, one is an isolated grave, and one is a mining operation with residential area. distinguishable entity whose components may lack individual distinction; or

D) have yielded, or may yield, information important in prehistory or history.

In addition, the integrity of individual properties should be evaluated in relation to like properties with a similar cultural theme, within the same geographical area, and generally within the same frame. It is within these contexts and criterion 
with wich we assess the historic components.

\section{Historic Site Recommendations}

\section{BP430}

Based on the management considerations discussed above, we assess 41BP430 - as "not recommended for the National Register of Historic Places, and no further investigations are recommended.

\section{BP138}

We concur with Mauldin's (2003:176) assessment that the following components of 41BP138 are "clearly eligible for inclusion on the National Register of Historic Places" under Criterion B, C, and D, but we would also include Criteria A: House/wine cellar, with adjacent barn, cistern, and well. We assess Scott Falls Dam and the irrigation channel as also eligible for inclusion. The grape fields associated with 41BP138 and 41BP105 are ineligible for inclusion.

However, due to the diversity of properties, we recommend specific means of protection for each as follows:

1) Aussiloux's house, cistern, and well are currently surrounded with a chain link fence and off limits to military training; we recommend no change.

2) Aussiloux's barn foundation should be surrounded with off limits to military training signs and Seibert stakes.

3) Aussiloux'sirrigation ditchis heavily eroded in some areas, quite visible in others. The canal can be traced for 20 meters below the dam adjacent to Spring Branch Creek, and this remnant section should be placed off limits to heavy equipment and digging below Scott Falls Dam. A second remnant section 30 meters long just east of Wine Cellar Road is also very visible. This 30 -meter section should also be placed off limits to heavy equipment and digging (see Figure 6-1).

4) The upper and lower fields should not be eligible for NRHP nomination because they lack any preserved evidence of integrity, but a request for Determination of Effect should be submitted to the Texas Historical Commission before the fields are further impacted. The 60-acre open field tract adjacent to Aussiloux's house and barn has never had any known structures on it. According to Abner C. Scott (personal communication, 29 April and 29 June 2004), the upper 60 acres was plowed by him for many years following Aussiloux's death in 1924. The Scott family raised sweet potatoes, watermelons, cantaloupes, and sweet peas on the property. In addition, both fields have been periodically used for heavy equipment training by the military since 1942. More recent activities include trenching for tank concealment.

Both fields are deemed critical to the training of heavy equipment operators for the military. Current tactical training activities scheduled for these areas include deep trenching for tank emplacement and concealment. The fields are considered desirable for this type of training because of their openness and their positions on the landscape.

Therefore, we recommend that the 60-acre upper field be placed off limits for any type of military training until a Determination of Effect is submitted to the Texas Historical Commission describing the type of military training that needs to be conducted in this area. For example, if digging either by hand or heavy machinery is conducted, the holes and trenches should be backfilled and the field leveled to its original grade.

5) Aussiloux's lower field consisting of two to 


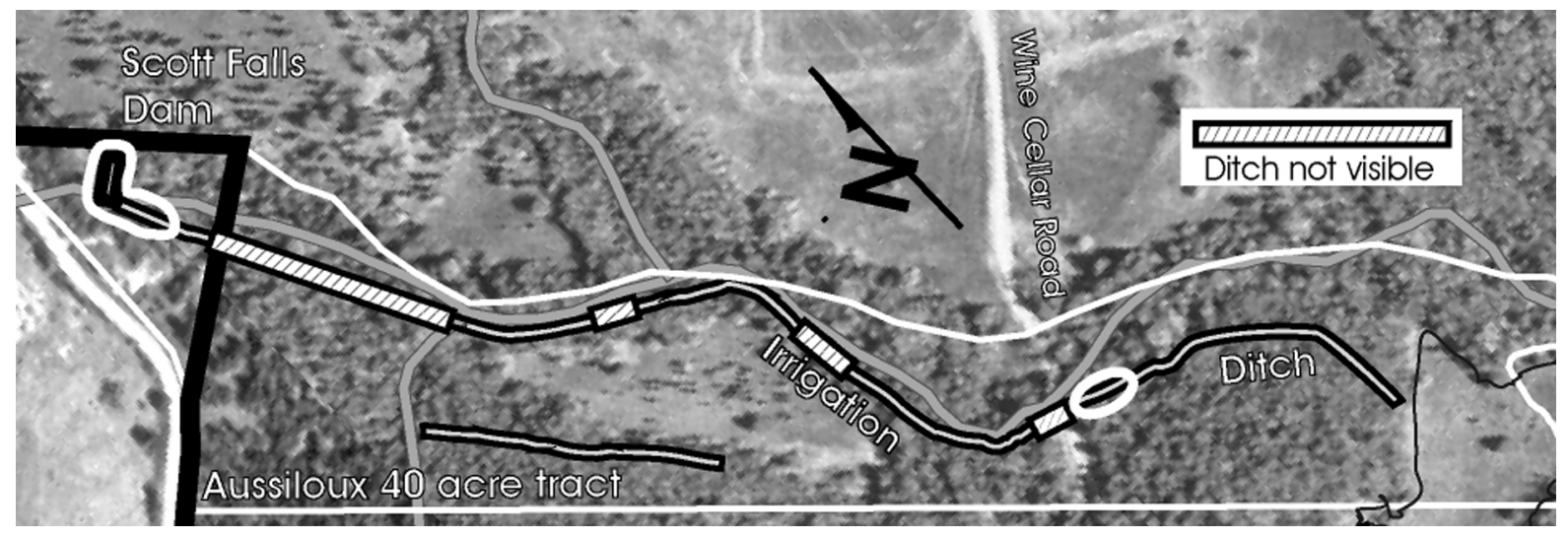

Figure 6-1 Scott Falls Dam and Aussiloux's irrigation ditch; areas recommended as off-limits are enclosed in bold "L" shape (at dam) and bold oval (east of Wine Cellar Road).

three acres encompasses 41BP105 (a half-acre prehistoric site). As for the field area outside 41BP105, we recommend the same as for the 60acre tract. The prehistoric component that is 41BP105 should be placed off limits until its significance is determined.

\section{BP146}

In order to properly identify the remains, indepth archival research with potential descendants should be conducted, possibly followed by scientific testing. In the near term, the presumably isolated grave at $41 \mathrm{BP} 146$ should be protected with a wellconstructed chain link fence and placed off limits to any type of military training or potentially threatening activities. Because of its location near the edges and confluence of a major drainage and a deeply incised tributary, consideration should be given to relocating the skeletal remains and sandstone slabs. In addition, carefully executed exploratory subsurface investigations for additional burials should be conducted.

\section{BP148/41BP170}

41BP148, the Sayersville Mine and residential area have essentially been dismantled and/or destroyed and are not recommended as eligible for nomination to the National Register of Historic Places. However, the cemetery (41BP170) has been placed "Off Limits", has been surrounded with a chainlink fence, and is otherwise protected and monitored by the Texas Army National Guard. 


\section{References Cited}

Baker, F. E.

1979 Soil Survey of Bastrop County, Texas. U.S. Department of Agriculture, Soil Conservation Service, Washington, D. C.

Barnes, V. E.

1974 Geological Atlas of Texas, Austin Sheet. Bureau of Economic Geology, University of Texas, Austin.

Bastrop County

1929 Map of Bastrop County, Texas. Copy on file in Bastrop County Courthouse, Deeds and Record Office. Randolph Blueprint Company, San Antonio, Texas.

Bastrop County. The Handbook of Texas online.

2002 http://www.tsha.tsha.utexas.edu/handbook/online/articles/view/BB/hcb3.html [Accessed Mon Feb 18 8:50:23 US/Central 2002].

Black, S. L.

1989a Central Texas Plateau Prairie. From the Gulf Coast to the Rio Grande: Human Adaptation in Central, South and Lower Pecos Texas, by T. R. Hester, S. L. Black, D. G. Steele, B. W. Olive, A. A. Fox, K. J. Reinhard, and L. C. Bement, pp. 17-38. Research Series No. 33. Arkansas Archeological Survey, Fayetteville.

1989b Environmental Setting. From the Gulf Coast to the Rio Grande: Human Adaptation in the Central, South, and Lower Pecos Texas, by T. R. Hester, S. L. Black, D. G. Steele, B. W. Olive, A. A. Fox, K. J. Reinhard, and L. C. Bement, pp. 5-17. Research Series No. 33. Arkansas Archeological Survey, Fayetteville.

Black, S. L., L. W. Ellis, D. G. Creel, and G. T. Goode

1997 Hot Rock Cooking on the Greater Edwards Plateau: Four Burned Rock Midden Sites in West Central Texas. 2 volumes. Studies in Archeology 22. Texas Archeological Research Laboratory, The University of Texas at Austin. Texas Department of Transportation Environmental Affairs Department, Archeology Studies Program, Report 2.

Blair, W. F.

1950 The Biotic Provinces of Texas. Texas Journal of Science 2(1):93-117. 


\section{Brown, K. M.}

1975 Time's Arrow and Postdepositional Disturbance. Paper presented at the 1975 Caddo Conference, College Station.

Bruseth, J. E. and W. A. Martin

2001 OSL Dating and Sandy-mantle Sites in East Texas. Current Archeology in Texas 3:1:12-17.

Cahen, D., and J. Moeyersons

1977 Subsurface Movements of Stone Artifacts and Their Implications for the Prehistory of Central Africa. Nature 266:812-815.

Chrestien, J. P.

1995 French Stoneware in North-Eastern North America. In Trade and Discovery: the Scientific Study of Artefacts from Post-Medieval Europe and Beyond, British Museum Occasional Paper, No. 109, pp. 91-103.

Clifton, R. T.

1970 Barbs, Prongs, Prickers, \& Stickers: A Complete and Illustrated Catalogue of Antique Barbed Wire. University of Oklahoma Press, Norman, OK.

Collins, M. B.

1995 Forty Years of Archeology in Central Texas. Bulletin of the Texas Archeological Society 66:361-400.

Collins, M. B., and K. M. Brown

2000 The Gault Gisement: Some Preliminary Observations. In Current Archeology in Texas 2(1):8-11.

Covey, C. (editor)

1961 Cabeza de Vaca's Adventures in the Unknown Interior of America. Collier Books, New York.

Creel, D. G.

1986 A Study of Prehistoric Burned Rock Middens in West Central Texas. Unpublished Ph.D. dissertation, The University of Arizona, Tucson.

Cutrer, T. W.

1985 The English Texans. The University of Texas Institute of Texas Cultures at San Antonio.

Dillehay, T.

1974 Late Quaternary Bison Population Changes on the Southern Plains. Plains Anthropologist (64):180196.

Fields, R. C. (editor)

1987 Excavations at the Alley Road site (41LN149B) and the Harris Hole site (41LN30), Jewett Mine Project, Leon County, Texas. Reports of Investigations No. 61. Prewitt and Associates, Inc., Austin. 
1990 Excavations at the Charles Cox, Lambs Creek Knoll and Buffalo Branch sites, Jewett Mine Project, Leon and Freestone Counties, Texas. Reports of Investigations No. 70. Prewitt and Associates, Inc., Austin.

Fields, R. C., S. V. Lisk, C. B. Bousman, W. Klement, J. Jackson, D. Utley, and J. Kock

1988 Archaeological Survey of the 1989-1993 Permit Area, Jewett Mine Project, Freestone and Leon Counties, Texas. Reports of Investigations No. 63. Prewitt and Associates, Inc., Austin.

Frazee, J. D.

1991 The Legacy of Antoine Aussiloux. Sayersville Historical Association Bulletin 9:11-13.

Freeman, M. D.

1979 Part II. Historic Resources. In A Cultural Resource Inventory and Assessment at Camp Swift, Texas, pp 81-123. Report No. 72, Texas Archeological Survey, University of Texas at Austin.

Gassaway, L.

1997 Landowners and Deed Research. Unpublished draft report on file in Camp Swift historical files, AGTX-EV, Camp Mabry, Texas.

Gifford, D. P., and A. K. Behrensmeyer

1977 Observed Formation and Burial of a Recent Human Occupation Site in Kenya. Quaternary Research 8:245-266.

Gifford-Gonzalez, D. P., D. B. Damrosch, D. R. Damsrosch. J. Pryor, and R. L. Thunen

1985 The Third Dimension in Site Structure: An Experiment in Trampling and Vertical Dispersal. American Antiquity 50(4):803-818.

Goode, G. T.

1989 Archaeological Testing and Recommendations for the Kennedy Bluffs Site, 41BP19, in Bastrop County, Texas. Appendix II. In Excavations at 41BP19, the Kennedy Bluffs Site, Bastrop County, Texas by L. C. Bement. Contract reports in Archaeology, Report 5, Texas State Department of Highways and Public Transportation, Highway Design Division, Austin.

Gould, F. W.

1975 Texas Plants-A Checklist and Ecological Summary. Bulletin MP-585:5-14. Texas Agricultural Experimentation Station, College Station.

Hall, G. D.

1998 Prehistoric Human Food Resource Patches on the Texas Coastal Plain. Bulletin of the Texas Archeological Society 69:1-10.

Heinrich, P. V.

1986 Geomorphology of Seven Sites at the Jewett Mine Project. In National Register Assessments of Archeological and Historical Resources at the Jewett Mine, Leon County, Texas, by R. C. Fields, S. V. Lisk, J. M. Jackson, M. D. Freeman, and G. L. Bailey, pp. 191-223. Reports of Investigations No. 48. Prewitt and Associates, Inc., Austin. 
Herms, L. C.

1938 Bastrop's Roll of Honor. <http:www.rootsweb.com/ txbastro/hermsmobley.gif> Accessed May 30, 9:35 AM.

Hester, T. R.

1995 The Prehistory of South Texas. Bulletin of the Texas Archeological Society 66:427-459.

Jelks, E. B.

1962 The Kyle Site: A Stratified Central Texas Aspect in Hill County, Texas. Archeology Series, No. 5. Department of Anthropology, The University of Texas, Austin.

Kay, L. H.

1997 Antoine Aussiloux: Early Texas Wine Industry. Unpublished draft report on file in Camp Swift historical files, AGTX-EV, Camp Mabry, Texas.

Kay, L. H., and S. A. Tomka

2001 Prehistoric Lithic Technology. In An Archaeological Inventory of Camp Swift, Bastrop County, Texas, pp. 160-173, edited by B. A. Meissner. Archaeological Survey Report Number 316, Center for Archaeological Research, The University of Texas at San Antonio.

Kovel, R., and T. Kovel

1986 Kovels' New Dictionary of Marks: Pottery and Porcelain 1850 to the Present. Crown Publishers Inc., New York.

Leach, J. D., and C. B. Bousman

1998 Cultural and Secondary Formation Processes: On the Dynamic Accumulation of Burned Rock Middens. Test Excavations at the Culebra Creek Site, 41BX126, Bexar County, Texas, pp. 119-145. Archaeological Survey Report, No. 265, Center for Archaeological Research, The University of Texas at San Antonio. Archeology Studies Program, Report 3, Environmental Affairs Division, Texas Department of Transportation, Austin.

Leffler, J. J.

2001 The History of the Camp Swift Area, 1830-1950. In An Archaeological Inventory of Camp Swift, Bastrop County, Texas, pp. 153-166, edited by B. Meissner. Archaeological Survey Report Number 316, Center for Archaeological Research, The University of Texas at San Antonio.

Marks, P. M.

1996 Bastrop, Texas. In The New Handbook of Texas, Volume 1, pp. 410-411, R. Tyler, editor in chief. Texas State Historical Association, Austin.

Mauldin, R. P.

2001 Assessments and Recommendations. In An Archaeological Inventory of Camp Swift, Bastrop County, Texas, pp. 175-186, edited by B. A. Meissner. Archaeological Survey Report Number 316, Center for Archaeological Research, The University of Texas at San Antonio. 
Mauldin, R. P., D. L. Nickels, and C. J. Broehm

2003 Archaeological testing to Determine the National Register Eligibility Status of Eighteen Prehistoric Sites on Camp Bowie, Brown County, Texas, 2 volumes. Archaeological Survey Report, No. 334, Center for Archaeological Research, The University of Texas at San Antonio; Adjutant General's Department of Texas, Directorate of Facilities and Engineering, Environmental Branch, Austin.

McCallum, F. T., and J. M. Owens

1996 Barbed Wire. In The New Handbook of Texas, Volume 1, pp. 377-378, R. Tyler, editor in chief. Texas State Historical Association, Austin.

Meissner, B. A. (editor).

2001 An Archaeological Inventory of Camp Swift, Bastrop County, Texas. Archaeological Survey Report Number 316, Center for Archaeological Research, The University of Texas at San Antonio.

Moore, B.

1977 Bastrop County, 1691-1900. Nortex Press, Wichita Falls, Texas.

Nash, M. A., R. F. Taylor, and E. A. Skokan

1995 A Cultural Resources Survey of the McNeil-Bastrop 138-Kv Transmission Line Rebuild Project, Bastrop and Travis Counties, Texas. Espey, Huston \& Associates, Austin.

Nickels, D. L.

2000 The Biesenbach Site (41WN88): A Case Study in Diet Breadth. Unpublished Master's Thesis, The University of Texas at San Antonio.

Nickels, D. L., M. L. Lehman, and C. B. Bousman

2003 Archaeological Evaluation of 39 Category V Sites at Camp Swift, Bastrop County, Texas: 2001. Archaeological Studies Report No. 3, Center for Archaeological Studies, Southwest Texas State University.

Nickels, D. L., D. W. Pease, and C. B. Bousman

1997 Archaeological Survey of Lackland Air Force Base, Bexar County, Texas. Archaeological Survey Report, No. 248. Center for Archaeological Research, The University of Texas at San Antonio.

Nightengale, B. A., and H. B. Moncure

1996 Intensive Cultural Resource Survey and Monitoring at the LCRA Camp Swift Regional Wastewater Project, Bastrop County, Texas. Cultural Resources Report No. 3, Lower Colorado River Authority, Environmental Protection Division, Austin.

Patterson, L. W.

1995 The Archeology of Southeast Texas. Bulletin of the Texas Archeological Society 66:239-264. 
Perttula, T. K.

1995 The Archeology of the Pineywoods and Post Oak Savanna of Northeast Texas. Bulletin of the Texas Archeological Society 66:331-359, Austin.

Prewitt, E. R.

1974 Archeological Investigations at the Loeve-Fox Site, Williams County, Texas. Research Report 49. Texas Archeological Survey, The University of Texas at Austin.

1991 Burned Rock Middens: A Summary of Previous Investigations and Interpretations. In The Burned Rock Middens of Texas: An Archeological Symposium, edited T. R. Hester, pp. 25-32. Studies in Archeology 13. Texas Archeological Research Laboratory, The University of Texas at Austin.

Prochnow, S.

2001 Geoarchaeological Assessment. In An Archaeological Inventory of Camp Swift, Bastrop County, Texas, pp. 31-37, edited by B. A. Meissner. Archaeological Survey Report Number 316, Center for Archaeological Research, The University of Texas at San Antonio.

Ricklis, R. A.

2001 National Register Eligibility Testing at 41LE177: Alcoa Sandow Mine, Lee County, Texas. Coastal Archaeological Research, Inc., Corpus Christi.

Robinson, D. G.

2001a Historic Contexts for Camp Swift. In An Archaeological Inventory of Camp Swift, Bastrop County, Texas, pp. 155-159, edited by B. A. Meissner. Archaeological Survey Report Number 316, Center for Archaeological Research, The University of Texas at San Antonio.

2001b Revisiting the Old Sayers Mine. Sayersville Historical Association Bulletin 11:7-11.

Robinson, D. G., T. M. Meade, L. Haslouer, L. Gassaway, and D. Kay

2001 An Archaeological Inventory of Camp Swift, Bastrop County, Texas, edited by B. A. Meissner. Archaeological Survey Report Number 316, Center for Archaeological Research, The University of Texas at San Antonio.

Rogers, R. and E. Foster

1994 National Register Assessment of Three Archaeological Sites at the Gibbons Creek Lignite Mine, Grimes County, Texas. Espey, Huston \& Associates, Inc., Austin.

Rogers, R.

1994 Excavations at site 41GM224 in the Gibbons Creek Lignite Mine Permit 38A Area, Grimes County, Texas. Espey, Huston \& Associates, Inc., Austin.

Schmidt, J. S., and M. E. Cruse

1995 Cultural Resources Survey, Camp Swift, Bastrop County, Texas. Espey, Huston \& Associates, Inc., Austin.

Sellards, E. H.

1940 Pleistocene Artifacts and Associated Fossils from Bee County, Texas. Bulletin of the Geological Society of America 51: 1627-1658. 
Skelton, D. W., and M. D. Freeman

1979 A Cultural Resource Inventory and Assessment at Camp Swift, Texas. Report No. 72, Texas Archeological Survey, University of Texas at Austin.

Smith, R, and F. Pannell

1984 Oak Hill: A Vanished Community. In The Sayersville Historical Bulletin, pp. 6-12. The Sayersville Historical Association.

Stevenson, M. G.

1991 Beyond the Formation of Hearth-Associated Artifact Assemblages. In The Interpretation of Archaeological Spatial Patterning, edited by E. M. Kroll and T. D. price, pp. 269-299. Plenium Press, New York.

Stockton, E. D.

1973 Shaw's Creek Shelter: Human Displacement of Artifacts and Its Significance. Mankind 9:112-117.

1977 Review of Early Bondaian Dates. Mankind 11:48-51.

Story, D. A.

1985 Adaptive Strategies of Archaic Cultures of the West Gulf Coastal Plain. In Prehistoric Food Production in North America, edited by R. I. Ford, pp. 19-56. Anthropological Papers No. 75. Museum of Anthropology, University of Michigan, Ann Arbor.

1990 Cultural History of the Native Americans. The Archeology of the Gulf Coastal Plain: Volume 1, pp. 163-366. Arkansas Archeological Survey Research Series No. 38.

Strong, B.

1996 James, John. In The New Handbook of Texas, Volume 3, pp. 905-910, R. Tyler, editor in chief. Texas State Historical Association, Austin.

Sullo, D. M., and A. J. Wormser

1996 Archeological Survey for Proposed Bradley Fighting Vehicle Training "Area A” at Camp Swift Military Reservation, Bastrop County, Texas. The Adjutant General's Department of Texas, Austin.

Templer, O. W.

2003 Grape Culture. The Handbook of Texas Online. http://www.tsha.utexas.edu/handbook/online/articles/ view/GG/afg2.html [Accessed Mon mar 3 13:50:53 US/Central 2003]

Tera Corporation

1978 Preliminary Drafts of Selected LCRA Inputs to BLM for Camp Swift Lignite Lease. Dallas.

Texas Genealogy

2003 Texas Geneaology, Texas General Website, Bastrop County, 1860 Census Records. http// www.bastropedc.org, accessed 12:39 PM, May 21, 2003. 
Thoms, A. V. (editor)

1993 The Brazos Valley Slopes Archaeological Project: Cultural Resources Assessments for the Texas A\&M University Animal Science Teaching and Research Complex, Brazos County, Texas. Archaeological Research Laboratory, Reports of Investigations No. 14. Texas A\&M University, College Station.

Turner, S. E., and T. R. Hester

1999 A Field Guide to Stone Artifacts of Texas Indians. Gulf Publishing Co, Houston.

Vierra, B.

1998 Archaeological Investigations at 41MV120, Maverick County, Texas. Archaeological Survey Report No. 251. Center for Archaeological research, The University of Texas at San Antonio.

Villa, P., and J. Courtin

1983 The Interpretation of Stratified Sites: A View from Underground. Journal of Archaeological Science 10:267-281.

Waters, M. R.

1992 Principles of Geoarchaeology: a North American Perspective. The University of Arizona Press, Tucson.

Weir, F. A.

1976 The Central Texas Archaic. Unpublished Ph.D. dissertation. Anthropology Department, Washington State University.

Wilbarger, J. W.

1985 Indian Depredations in Texas: Original Narratives of Texas History and Adventure, 1885. Reprinted by Eakin Press, Austin.

Winship, G. P.

1896 The Coronado Expedition, 1540-1542. In Fourteenth Annual report of the Bureau of American Etnology 1892-1893, Part I, pp. 339-637. Government Printing Office, Washington, D. C.

Yellen, J. E.

1977 Archaeological Approaches to the Present: Models for Predicting the Past. Academic Press, New York. 


\section{Additional Investigations at 41 BP384}

\section{David L. Nickels}

\section{Background}

41BP384 is one of 39 Category V sites that were recommended for further evaluation (Mauldin
2003). CAS archaeologists returned to the site in 2001, conducted additional testing, and because of disturbance that had occurred, assessed the site as ineligible for nomination to the National Register of Historic Places. In March 2003, Shellie Sullo and Michael Jordan of the AGTX observed an ephemeral scatter of firecracked rocks and lithic debitage in a pipeline right-of-way on the opposite side of an intermittent drainage where shovel testing was previously conducted. CAS archaeologists returned to the site, excavated an additional seven shovel tests, and otherwise gathered additional data. This appendix provides the results of our return to the site in March 2003.

\section{Description}

41BP384 (Figure A-1) is a prehistoric open campsite with burned rock and an associated lithic scatter. The approximate site size is $6,000 \mathrm{~m}^{2}$ and the elevation ranges from 440 to 445 feet. It is situated

Figure A-1. Site map, 41BP384. 
on a terrace of Axtell fine sandy loam (AfC2) formed along an intermittent tributary of Harris Creek. A dense stand of oak with briar understory are the predominant vegetation on the southern portion, while the northern portion has been mechanically cleared. A 2-m deep cutbank created during construction of a powerline right-of-way, has exposed sandstone bedrock is in the southern portion of the site, with the cleared right-of-way extending through the center. The intermittent drainage and an improved gravel road also cut through the center.

\section{Levels of Work and Results}

When 41BP384 was initially investigated by Nash et al. in 1995, there was a possible hearth feature eroding out of a bulldozed area, but no other evidence of cultural material In 2001, CASSWT personnel conducted a 100 percent surface inventory and examination of the bulldozed and natural stream cutbanks that revealed only two scattered pieces of firecracked rock, both lying on the right-of-way surface. Although a few flakes were also observed along the right-of-way, all appeared to be crushed by heavy machinery. Five shovel tests (1-5) excavated at that time were all negative (Nickels et al. 2003).

A subsequent visit in March 2003 by AGTX Cultural Resources archaeologists resulted in the discovery of an ephemeral scatter of firecracked rocks and flakes on the surface in the northern portion of the site. CAS archaeologists revisited the site on March 12, 2003 to evaluate the northern area of the site that was to be impacted by an expansion of the pipeline right-of-way.

After examining the surface and an exposed cutbank, CAS personnel excavated a total of seven additional shovel tests (6-12); four in the open, grassy area of the existing and proposed rights-ofway, and three in the wooded treeline adjacent to an unnamed, intermittent drainage (Figure A-1). All tests were dug in 10-cm levels, sediments were screened through $1 / 4$-inch wire mesh, and all shovel tests and modern construction features were mapped with a global positioning system.

An examination of the exposed, 90-cm-deep cutbank in the open, right-of-way area, and perpendicular to the drainage revealed only mottled gray and orange clay. The sediments encountered to 1-m deep in the four shovel tests placed in the right-of-way were the same, indicating that the area has undergone extensive disturbance.

Although an upper 20-30 cm of loam was encountered in the three shovel tests placed in the wooded area along the edge of the drainage, mottled clays was found to $1 \mathrm{~m}$ deep in two of the three; in the third, a matrix of caliche, loam and rounded fill gravels were found covering pre-Pleistocene orange clay at $65 \mathrm{~cm}$ below the surface. The presence of loam in the upper levels is attributable to bulldozing; large trees had been toppled on the edge of the creek, and pushpiles were observed in the underbrush. A total of 11 pieces of chipped stone, 5 small pieces of firecracked rock, a clear glass sherd, and a spent ammunition cartridge were found within the fill sediments.

\section{Conclusions and Recommendations}

The results of shovel testing previously conducted on the site in 2001 indicated that the site was of minimal significance, and thus was not recommended as eligible for nomination to the National Register of Historic Places. The results of our additional shovel testing conducted on March 12, 2003 indicate that the area to be impacted by an expanded pipeline right-of-way had 
likely been a side drainage filled in with clays and gravels to cover and protect the current pipeline running through it. Cultural material found in the shovel tests were most probably transported in with the clays and gravels used to fill in the drainage. In sum, our additional testing found no evidence of intact cultural deposits, and our assessment as "not eligible for nomination to the National Register of Historic Places" remains unchanged. 



\section{Appendix B \\ Combined USGS Map Showing Site Locations}

COMBINED USGS MAP SHOWING SITE LOCATIONS REDACTED 